ESCOLA POLITÉCNICA DA UNIVERSIDADE DE SÃO PAULO

RODRIGO DE FREITAS BUENO

AVALIAÇÃO DA NITRIFICAÇÃO E DESNITRIFICAÇÃO SIMULTÂNEA EM ESTAÇÃO DE TRATAMENTO DE ESGOTO EM ESCALA REAL

SÃO PAULO 


\section{AVALIAÇÃO DA NITRIFICAÇÃO E DESNITRIFICAÇÃO SIMULTÂNEA EM ESTAÇÃO DE TRATAMENTO DE ESGOTO EM ESCALA REAL}

Tese apresentada à Escola Politécnica da Universidade de São Paulo para obtenção de título de Doutor em Ciências.

Programa: Engenharia Civil, na área de concentração de Engenharia Hidráulica Orientador: Prof. Dr. Roque Passos Piveli

SÃO PAULO 
ESCOLA POLITÉCNICA DA UNIVERSIDADE DE SÃO PAULO

RODRIGO DE FREITAS BUENO

AVALIAÇÃO DA NITRIFICAÇÃO E DESNITRIFICAÇÃO SIMULTÂNEA EM ESTAÇÃO DE TRATAMENTO DE ESGOTO EM ESCALA REAL

Tese apresentada à Escola Politécnica da Universidade de São Paulo para obtenção de título de Doutor em Ciências.

SÃO PAULO 
de Freitas Bueno, Rodrigo

AVALIAÇÃO DA NITRIFICAÇÃO E DESNITRIFICAÇÃO SIMULTÂNEA EM ESTAÇÃO DE TRATAMENTO DE ESGOTO EM ESCALA REAL / R. de Freitas Bueno -- São Paulo, 2016. $236 \mathrm{p}$.

Tese (Doutorado) - Escola Politécnica da Universidade de São Paulo. Departamento de Engenharia de Hidráulica e Ambiental.

1.Nitrificação e Desnitrificação Simultânea (NDS) 2.Lodos ativados 3.Baixa concentração de oxigênio 4.Remoção biológica de nitrogênio 5.Esgoto sanitário I.Universidade de São Paulo. Escola Politécnica. Departamento de Engenharia de Hidráulica e Ambiental II.t. 
É expressamente proibida a comercialização deste documento, tanto na sua forma impressa como eletrônica. Sua reprodução total ou parcial é permitida exclusivamente para fins acadêmicos e científicos, desde que na reprodução figure a identificação do autor, título, instituição e ano da tese. 


\section{AGRADECIMENTOS}

Esta tese é um produto sinérgico aos estudos realizados por grandes pesquisadores e profissionais envolvidos na área de tratamento de esgotos. Sou grato a muitos pensadores pela inspiração e pela sabedoria, e pelas raízes e fontes de sua sabedoria.

Também agradeço a Deus e a minha família pelo apoio e força em todos os momentos difíceis.

Pelo desenvolvimento e pela produção desta tese sou imensamente grato a:

Professor Roque Passos Piveli, pela orientação desta tese, pela amizade, dedicação e paciência e, em especial por ser um profissional admirável.

Professor Pedro Além Sobrinho, pelas orientações e conselhos que engrandeceram de forma expressiva nossos conhecimentos, contribuindo grandemente na realização deste trabalho.

Professor Adrianus C. Van Haandel, que gentilmente nos cedeu o respirômetro e pelos conselhos e orientações na defesa do mestrado, contribuindo grandemente na continuidade deste trabalho.

Aos amigos da EPUSP, em especial, Fábio Campos e Laerte pela amizade e pelo auxílio na realização das análises laboratoriais, na operação do sistema experimental e na troca de conhecimentos.

Aos amigos da SABESP de Presidente Prudente, em especial, Eng. Gilmar Peixoto, ao eletricista Caciari, a Márcia Silva do laboratório, ao encarregado Olavo Bonifacio e aos amigos operadores, agradeço pela amizade e por suas múltiplas e excelentes sugestões.

Aos amigos da FIOCRUZ, Prof. Jaime Oliveira e o Prof. Renato Ribeiro, pela ajuda com as análises de biologia molecular.

A FAPESP e a SABESP pela disponibilização da bolsa de doutorado e financiamento da pesquisa e, a Escola Politécnica da Universidade de São Paulo.

E a todos que de alguma forma contribuíram para que essa dissertação pudesse ser concluída com êxito. 
"Sozinho não se chega a lugar algum" - John Maxwell 


\section{RESUMO}

BUENO, R. F. Avaliação da nitrificação e desnitrificação simultânea em estação de tratamento de esgoto em escala real. 2016. 235p. Tese [Doutorado] - Escola Politécnica da Universidade de São Paulo, São Paulo, 2016.

Esta pesquisa teve por objetivo a produção de elementos para a avaliação da viabilidade de se agregar novas tecnologias a uma estação de tratamento de esgoto sanitário pelo processo de lodo ativado com aeração prolongada em escala real. $\mathrm{O}$ estudo foi desenvolvido na ETE Limoeiro da SABESP, localizada no Município de Presidente Prudente/SP. Foi estudado a remoção biológica de nitrogênio via nitrificação e desnitrificação simultânea (NDS), controlando-se a idade do lodo e o sistema de fornecimento de ar por meio de sensores de concentração de oxigênio dissolvido de luminescência (LDO), amônia e nitrato, e de potencial de óxido-redução instalados nos tanques de aeração. No controle do processo foi avaliado a emissão de óxido nitroso e determinado os parâmetros cinéticos da nitrificação e desnitrificação, por meio de testes respirométricos. Foi utilizado a técnica de biologia molecular de FISH para identificação das bactérias nitritantes, nitratantes e desnitrificantes envolvidas no processo da NDS. Em termos de remoção de matéria orgânica, a qualidade do efluente final foi compatível aos processos de lodos ativados tradicionais com OD na faixa de 2,0 mgOz/L, com eficiências entre 85 a 95\% de DQO e DBO. Os resultados demostraram que a nitrificação do esgoto ocorreu de forma eficiente, resultando concentrações de amônia no efluente final menores que $3,8 \mathrm{mgN}$ $\mathrm{NH}$ 3/L. Os resultados de concentração de nitrato no efluente final do processo de lodos ativados demonstram a expressiva eficiência do processo de desnitrificação, resultando em concentrações de nitrato no efluente final menores que $2,5 \mathrm{mgN}$ NO3/L. A otimização do sistema de aeração resultou em uma economia média de 34\% com o gasto de energia elétrica para aeração do sistema. Conclui-se que o processo de lodos ativados com nitrificação e desnitrificação simultânea de fluxo contínuo é uma alternativa promissora de tratamento, a ser considerada tano nos estudos de concepção para implantação de novas estações como na adaptação de processos de lodos ativados já existentes.

Palavras-chave: Nitrificação e desnitrificação simultânea (NDS); lodos ativados; aeração prolongada; baixa concentração de oxigênio; respirometria. 


\begin{abstract}
BUENO, R. F. Evaluation simultaneous nitrification and denitrification in sewage treatment plant full scale. 2016. 235p. Thesis [PhD] - Escola Politécnica da Universidade de São Paulo, São Paulo, 2016.

This research aimed at the production of elements for assessing the feasibility of adding new technologies to a sewage treatment plant for sludge process with extended aeration activated in real scale. The study was developed in ETE Limoeiro SABESP, located in the Municipality of President Prudente / SP. Biological nitrogen removal by biological nitrification and simultaneous denitrification was studied (NDS), controlling the sludge age and the system supply air through oxygen concentration sensors dissolved luminescence (LDO), ammonia and nitrates, and the redox potential installed in the aeration tanks. In process control, the emission of nitrous oxide was evaluated and determined the kinetic parameters of nitrification and denitrification, by molecular biology techniques FISH was the identification nitritantes bacteria and denitrifying nitratantes involved in the process of NDS. In terms of removal of organic matter, the effluent quality is compatible to traditional activated sludge processes, with efficiencies from 85 to $95 \%$ of COD and BOD. The results showed that the sewer nitrification took place efficiently, resulting in ammonia concentrations in the final effluent smaller than 3.8 NH3 mgN / L. The nitrate concentration results in the final effluent from the activated sludge process demonstrate the significant efficiency of denitrification process, resulting in nitrate concentration in the final effluent smaller than $2.5 \mathrm{mgN}$ NO3 / I. Optimization of the aeration system resulted in an average savings of $34 \%$ with the electricity spent aeration system. We conclude that the activated sludge process with nitrification and denitrification simultaneous streaming is a promising alternative treatment to be considered thane in design studies for implementation of new stations as the adaptation of sludge processes already activated.
\end{abstract}

Keywords: Simultaneous nitrification and denitrification (SND); activated sludge; extended aeration; low oxygen concentration; respirometry. 


\section{LISTA DE FIGURAS}

Figura 1: Conversões possíveis entre compostos nitrogenados ............................32

Figura 2: Bactérias Nitrosomonas sp. e Nitrobacter sp. ………………………....33

Figura 3: Variação do número de oxidação de nitrogênio nos processos de nitrificação e desnitrificação. Fonte: (Van Haandel e Marais1999).

Figura 4: Representação da variação da concentração de OD num floco em função da distância do centro para concentração subcrítica, crítica e supercrítica. Fonte: (Van Haandel e Marais1999).

Figura 5: Variação teórica versus variação experimental da alcalinidade para diferentes sistemas de lodo ativado. Fonte: (Van Haandel e Marais, 1999).

Figura 6: Esquema das unidades da etapa biológica do sistema de lodo ativado ....52

Figura 7: Representação esquemática de um sistema de lodo ativado com prédesnitrificação.

Figura 8: Representação esquemática de um sistema de lodo ativado com pósdesnitrificação.

Figura 9: Representação esquemática de um sistema de lodo ativado pelo processo Bardenpho de 3 estágios.

Figura 10: Representação esquemática de um sistema de lodo ativado pelo processo UCT com 5 reatores sequenciais (anaeróbio-anóxico-aeróbio-anóxico-aeróbio)......57

Figura 11: Processo SHARON associado à ANAMMOX ANÓXICO ..........................61

Figura 12: Esquema básico de distribuição das zonas do SCLA .............................64

Figura 13: Zonas aeróbia, anóxica e anaeróbia em grânulos aeróbios

Figura 14: Esquema dos transportes e transformações que podem ocorrer em um floco em meio com baixa concentração de oxigênio dissolvido. Fonte: Adaptado de (Metcalf e Eddy, 2013) ............................................................................

Figura 15: Relação entre concentração de oxigênio dissolvido e idade do lodo para obtenção de efluente com 1,0 mg.L-1 de N-NH4+, a $20^{\circ} \mathrm{C}$ para $\mathrm{Ko}=0,5 \mathrm{mg} \cdot \mathrm{L}-1$. Fonte: Adaptado de (Metcalf e Eddy, 2013).

Figura 16: Efeito da concentração de OD na velocidade de desnitrificação. Fonte: Adaptado de (Metcalf e Eddy, 2013). .76

Figura 17: Representação esquemática de um sistema de lodo ativado de remoção de nitrogênio, modificado para operar com baixa concentração de OD.

Figura 18: Representação esquemática de um sistema de lodo ativado tipo OrbalTM de remoção de nitrogênio, modificado para operar com baixa concentração de OD promovendo o processo de NDS. Fonte: Adaptado de (Metcalf e Eddy, 2013). 
Figura 19: Estação de tratamento de esgoto Limoeiro (SABESP)

Figura 20: Tratamento preliminar do esgoto à entrada do processo de lodos ativados

Figura 21: Conjunto moto-bomba de recalque de esgoto à entrada do desarenador96

Figura 22: Desarenador do tipo tanque quadrado com limpeza mecanizada .97

Figura 23: Caixa distribuidora de vazão de esgoto

Figura 24: Substituição do sistema de aeração dos tanques da ETE Limoeiro 98

Figura 25: Arranjo experimental e disposição das sondas de OD nos tanques de aeração. 100

Figura 26: Variação no tempo da entrada e saída de processo (a) não-controlado e (b) controlado. Adaptado de Andrews, 1974

Figura 27: Estrutura resumida do controle de oxigênio dissolvido no tanque de aeração. 101

Figura 28: Equipamentos de controle do sistema de aeração 102

Figura 29: Vista dos sensores de LDO, pH e Redox instalados no tanque de aeração 103

Figura 30: Sistema de controle de Nitrato instalado no canal do efluente final .......104

Figura 31: Vista dos decantadores secundários da ETE Limoeiro ..........................105

Figura 32: Caixa divisora de vazão e conjunto moto-bombas ...............................105

Figura 33: Adensadores e tanque de armazenamento de lodo ..............................106

Figura 34: Desaguamento do lodo por meio de decanters centrífugos ...................107

Figura 35: Pátio de estocagem de lodo, aterro sanitário e bags. ...........................108

Figura 36: Tanque de contato e armazenamento do cloro gás ..............................109

Figura 37: Calha Parshall seguido de escada hidráulica......................................109

Figura 38: Amostrador automático com nicho de proteção implantado na ETE.....111

Figura 39: Pontos de amostragem de $\mathrm{N}_{2} \mathrm{O}$ no tanque de aeração ...........................112

Figura 40: Medidor infravermelho e câmara flutuante de amostragem de gás........113

Figura 41: Aparato experimental utilizado nos testes de sedimentabilidade do lodo. 
Figura 42: Fluxograma do processo básico de tratamento e dimensionamento das imagens para a quantificação e medição da geometria dos flocos.

Figura 43: Comparação entre as imagens originais e os flocos reconhecidos pelo Image J - A) lodo ativado aeração prolongada, B) lodo ativado convencional ........118

Figura 44: Respirômetro do tipo aberto e semi-contínuo

Figura 45: Respirograma experimental com medições de OD na faixa de $(0,3-0,8$ mg.L-1) e TCO endógena.

Figura 46: Reator utilizado nos testes respirométricos, (a) reator e haste para mistura,

(b) sistema montado para realização do teste. 122

Figura 47: Respirograma genérico da adição de um substrato solúvel a uma batelada de lodo ativado..... 125

Figura 48: Exemplo de um respirograma experimental com adição de amônia como substrato em uma batelada de lodo ativado.

Figura 49: Respirograma experimental da determinação das frações do material orgânico. 130

Figura 50: Corte esquemático do sistema de lodo ativado com sensores de medição online. 133

Figura 51: ETE piloto implantada no local da pesquisa 134

Figura 52: Diagramas Box-Whiskers das vazões afluente e efluente - ETE LimoeiroSabesp 136

Figura 53: Diagramas Box-Whiskers da Série de Sólidos 138

Figura 54: Diagramas Box-Whiskers da concentração de SST no Afluente e Efluente da ETE 139

Figura 55: Diagramas Box-Whiskers da idade do lodo ativado 141

Figura 56: Diagramas Box-Whiskers do IVL no tanque de aeração 142

Figura 57: Altura da interface do lodo em função do tempo (OD = 0,3 a 0,8 mg/L) 144

Figura 58: Altura da interface do lodo em função do tempo (OD =1,0 a 1,5 mg/L) 145

Figura 59: Velocidade de sedimentação da interface do lodo em função da concentração de sólidos 146

Figura 60: Teste de sedimentabilidade em condições normais de operação. 148

Figura 61: Teste de sedimentabilidade após 2 horas de aeração 148 
Figura 62: Imagens digitais adquiridas por microscopia (aumento 40X) e tratadas no programa ImageJ (a) imagem dos flocos identificadas pelo progrma (b) imagem tratada para análise estatística.

Figura 63: Série temporal (média diária): OD nos tanques de aeração 150

Figura 64: Diagramas Box-Whiskers da concentração de OD nos tanques de aeração

Figura 65: Temperatura nos tanques de aeração 153

Figura 66: Diagramas Box-Whiskers da temperatura do lodo ativado 155

Figura 67: $\mathrm{pH}$ do lodo ativado nos tanques de aeração 156

Figura 68: Diagramas Box-Whiskers da pH nos tanques de aeração 158

Figura 69: ORP no lodo dos tanques de aeração 159

Figura 70: Diagramas Box-Whiskers do ORP no lodo dos tanques de aeração .....160

Figura 71: Série temporal das concentrações de DBO à entrada e à saída do processo de lodos ativados

Figura 72: Diagramas Box-Whiskers - DBO e Eficiências afluente e efluente do processo de lodos ativados 163

Figura 73: Série temporal das concentrações de DQO à entrada e à saída do processo de lodos ativados 165

Figura 74: Diagramas Box-Whiskers - DQO e Eficiências afluente e efluente do processo de lodos ativados 167

Figura 75: Série temporal de NKT e N-Amoniacal afluente e efluente do processo de lodos ativados 172

Figura 76: Diagramas Box-Whiskers de NKT e N-Amoniacal no afluente e efluente do processo de lodos ativados 174

Figura 77: Série temporal do Nitrato no efluente do processo de lodos ativados....176

Figura 78: Diagramas Box-Whiskers de $\mathrm{N}-\mathrm{NO}_{3}$ no efluente do processo de lodos ativados

Figura 79: Série temporal do monitoramento online de nitrato no efluente do processo de lodos ativados

Figura 80: Diagramas Box-Whiskers do monitoramento online de $\mathrm{N}-\mathrm{NO}_{3}$ no efluente do processo de lodos ativados.

Figura 81: Balanço de massa do material nitrogenado ensaio I 183

Figura 82: Balanço de massa do material nitrogenado ensaio II 
Figura 83: Série temporal da Alcalinidade no esgoto afluente e efluente do processo de lodos ativados

Figura 84: Diagramas Box-Whiskers da Alcalinidade do esgoto afluente e efluente do processo de lodos ativados 186

Figura 85: Resultado do balanço de alcalinidade no processo de lodos ativados ..188 Figura 86: Fluxograma geral referente às frações de material orgânico - 2015 191

Figura 87: Exemplo de Respirograma para determinação de constantes cinéticas das bactérias autotróficas. 194

Figura 88: Teste de presença ou ausência de bactérias nitritantes no processo de NDS. 198

Figura 89: Teste de presença ou ausência de bactérias nitratantes no processo de NDS. 198

Figura 90: Teste de presença ou ausência de bactérias desnitrificantes no processo de NDS. 199

Figura 91: Série temporal da vazão de esgoto à entrada e à saída do processo de lodos ativados da ETE Piloto 203

Figura 92: Diagramas Box-Whiskers da vazão de entrada e saída do processo de lodos ativados da ETE Piloto. 203

Figura 93: Série temporal com médias móveis de 4 termos das concentrações de sólidos no efluente à saída da ETE Piloto 205

Figura 94: Diagramas Box-Whiskers dos SST no efluente final da ETE Piloto .......205

Figura 95: Série temporal (média diária): OD nos tanques de aeração 207

Figura 96: Diagramas Box-Whiskers do OD do lodo no tanque de aeração da ETE Piloto 207

Figura 97: Série temporal das concentrações de DBO e DQO à entrada e à saída do processo de lodos ativados da ETE Piloto 208

Figura 98: Diagramas Box-Whiskers de DQO e DBO (total e solúvel) afluente e efluente do processo de lodos ativados da ETE Piloto. 209

Figura 99: Série temporal das concentrações de NKT e N-NH 3 à entrada e à saída do processo de lodos ativados da ETE Piloto 212

Figura 100: Diagramas Box-Whiskers de NKT e NH3 afluente e efluente do processo de lodos ativados da ETE Piloto. 212

Figura 101: Série temporal das concentrações de nitrato à entrada e à saída do processo de lodos ativados da ETE Piloto 213 
Figura 102: Diagramas Box-Whiskers de nitrato afluente e efluente do processo de lodos ativados da ETE Piloto......................................................................214 


\section{LISTA DE TABELAS}

Tabela 1: Taxa de desnitrificação por miligrama de sólidos suspensos voláteis por dia, em sistemas de lodo ativado com pré-desnitrificação e pós-desnitrificação. .55

Tabela 2: Coeficientes cinéticos típicos do processo de nitrificação .76

Tabela 3: Principais características dos sistemas de lodos ativados utilizados para o tratamento de esgotos domésticos.

Tabela 4: Valores de referência das constantes cinéticas de utilização de material orgânico

Tabela 5: Valores de referência das constantes de decaimento de Nitrosomonas (bn)

Tabela 6: Valores das constantes de meia saturação de amônia para as Nitrosomonas $(\mathrm{Kn})$

Tabela 7: Valores das constantes de crescimento específico máximo de Nitrosomonas $(\mu \mathrm{m})$.

Tabela 8: Variáveis controladas nos afluentes e efluentes, pontos de amostragem e frequências.

Tabela 9: Variáveis controladas nos lodos, pontos de amostragem e frequências .114

Tabela 10: Equações utilizadas para determinação do balanço de massa do material orgânico

Tabela 11: Equações utilizadas para determinação do balanço de massa do material nitrogenado

Tabela 12: Substratos para os testes respirométricos com bactérias autotróficas nitrificantes 123

Tabela 13: Sondas oligonucleotídicas e os grupos microbianos alvo. 132

Tabela 14: Vazão de esgoto afluente ao processo de lodos ativados 135

Tabela 15: Vazão de esgoto efluente ao processo de lodos ativados 135

Tabela 16: Resumo das cargas orgânicas tratadas no período de 2012 a 2015 na ETE Limoeiro - SABESP.

Tabela 17: Sólidos em suspensão nos tanques de aeração (2012 e 2013)

Tabela 18: Sólidos em suspensão nos tanques de aeração (2014 e 2015) 138

Tabela 19: Sólidos em suspensão total no efluente da ETE 139 
Tabela 20: Valores médios da idade do lodo 140

Tabela 21: Índice volumétrico do lodo no tanque de aeração 142

Tabela 22: Altura da interface do lodo em diferentes tempos do teste $(O D=0,3$ a 0,8 $\left.\mathrm{mgO}_{2} / \mathrm{L}\right)$ 143

Tabela 23: Altura da interface do lodo em diferentes tempos do teste $(O D=1,0$ a 1,5 $\left.\mathrm{mgO}_{2} / \mathrm{L}\right)$ 144

Tabela 24: Coeficientes do teste de sedimentabilidade do lodo ativado 146

Tabela 25: Velocidades de sedimentação para diferentes concentrações de sólidos 147

Tabela 26: Estatística descritiva do diâmetro dos flocos do lodo 149

Tabela 27: Concentrações de OD nos tanques de aeração (2012-2013) ...............151

Tabela 28: Concentrações de OD nos tanques de aeração (2014-2015) ...............152

Tabela 29: Valores médios da temperatura do lodo ativado ..................................154

Tabela 30: Valores médios da temperatura do lodo ativado .................................154

Tabela 31: Valores médios de pH nos tanques de aeração ...................................157

Tabela 32: Valores médios de pH nos tanques de aeração ...................................157

Tabela 33: valores do ORP no lodo dos tanques de aeração .................................159

Tabela 34: Concentrações médias de DBO no processo de lodos ativados (2012) 161

Tabela 35: Concentrações médias de DBO no processo de lodos ativados (2013) 162

Tabela 36: Concentrações médias de DBO no processo de lodos ativados (2014) 162

Tabela 37: Concentrações médias de DBO no processo de lodos ativados (2015) 162

Tabela 38: Concentrações médias de DQO no processo de lodos ativados (2012) 166

Tabela 39: Concentrações médias de DQO no processo de lodos ativados (2013) 166

Tabela 40: Concentrações médias de DQO no processo de lodos ativados (2014) 166

Tabela 41: Concentrações médias de DQO no processo de lodos ativados (2015) 166

Tabela 42: Taxa de consumo de oxigênio no lodo durante as 169 
Tabela 43: Taxa de consumo de oxigênio no lodo durante as Etapas I e II. 169

Tabela 44: Balanço de massa de material orgânico no sistema

Tabela 45: Concentrações médias de NKT-N e N-Amoniacal no afluente e efluente do processo de lodos ativados

Tabela 46: Concentrações médias de NKT-N e N-Amoniacal no afluente e efluente do processo de lodos ativados

Tabela 47: $\mathrm{N}-\mathrm{NO}_{3}$ no efluente do processo de lodos ativados

Tabela 48: $\mathrm{N}-\mathrm{NO}_{3}$ no efluente do processo de lodos ativados

Tabela 49: Balanço de massa do material nitrogenado no sistema

Tabela 50: Monitoramento da emissão de $\mathrm{N}_{2} \mathrm{O}$ no tanque de aeração

Tabela 51: Valores médios de alcalinidade no esgoto afluente e efluente e a variação obtida experimentalmente devido à amonificação, nitrificação e desnitrificação (20122013).

Tabela 52: Valores médios de alcalinidade no esgoto afluente e efluente e a variação obtida experimentalmente devido à amonificação, nitrificação e desnitrificação (20142015)

Tabela 53: Variação da alcalinidade teórica causada pelo efeito estequiométrico devido à amonificação, nitrificação e desnitrificação (2012-2013).

Tabela 54: Variação da alcalinidade teórica causada pelo efeito estequiométrico devido à amonificação, nitrificação e desnitrificação (2014-2015) 188

Tabela 55: Frações de matéria orgânica presente no esgoto sanitário 190

Tabela 56: Valores médios das constantes cinéticas de utilização de material orgânico 192

Tabela 57: Valores médios da TCO pelas bactérias oxidadoras de amônia 195

Tabela 58: Valores médios da TCO pelas bactérias oxidadoras de nitrito 195

Tabela 59: Valores médios das constantes de crescimento específico máximo das bactérias oxidadoras de amônia $(\mu \mathrm{m} 20)$.

Tabela 60: Valores médios das constantes de crescimento específico máximo das bactérias oxidadoras de nitrito $\left(\mu_{\mathrm{m} 20}\right)$.

Tabela 61: Valores médios da vazão de entrada e saída do processo de lodos ativados da ETE Piloto 203

Tabela 62: Concentrações de sólidos em suspensão e suas frações nos tanques de aeração 204 
Tabela 63: Valores médios dos SST no efluente final da ETE Piloto .205

Tabela 64: Índice volumétrico do lodo no tanque de aeração da ETE Piloto ..........206

Tabela 65: Valores de OD no lodo do tanque de aeração da ETE Piloto. 207

Tabela 66: Concentrações médias de DBO e DQO no processo de lodos ativados da ETE Piloto 209

Tabela 67: Concentrações médias de DBO e DQO solúvel no processo de lodos ativados da ETE Piloto 209

Tabela 68: Concentrações médias de NKT e N-NH 3 no processo de lodos ativados da ETE Piloto 212

Tabela 69: Concentrações médias de nitrato no processo de lodos ativados da ETE Piloto 213

Tabela 70: Valores médios de alcalinidade no esgoto afluente e efluente e a variação obtida experimentalmente devido à amonificação, nitrificação e desnitrificação na ETE Piloto .215

Tabela 71: Valores médios das constantes cinéticas de utilização de material orgânico 218

Tabela 72: Valores médios da TCO pelas BOA e BON 218

Tabela 73: Valores médios das constantes de crescimento específico máximo das bactérias nitrificantes $\left(\mu_{\mathrm{m} 20}\right)$ 220 


\section{LISTA DE ABREVIATURAS, SIGLAS E SÍMBOLOS}

$\mu \mathrm{m}:$ Taxa específica de crescimento $\left(\mathrm{d}^{-1}\right)$

$\mu$ máx: Taxa específica máxima de crescimento $\left(\mathrm{d}^{-1}\right)$

$\mu_{\mathrm{mT}}$ : Taxa de crescimento máximo das bactérias a uma temperatura $\mathrm{T}\left(\mathrm{d}^{-1}\right)$

a: Recirculação de licor misto

ANAMMOX: Anaerobic Ammonium Oxidation

AT: Amplitude total

bh: Decaimento de bactérias heterotróficas $\left(\mathrm{d}^{-1}\right)$

$b_{n}$ : Constante de decaimento para as bactérias autotróficas nitrificantes $\left(\mathrm{d}^{-1}\right)$

$\mathrm{B}_{\mathrm{n}}$ : Balanço de massa de material nitrogenado

Bo: Balanço de massa de material orgânico

Cr: Massa de lodo ativo presente no sistema por unidade de DQO

CRUSP: Conjunto residencial da Universidade de São Paulo

CTH: Centro Tecnológico de Hidráulica - Escola Politécnica da Universidade de São Paulo

CV: Coeficiente de variação

DBO: Demanda Bioquímica de Oxigênio (mg. $\left.\mathrm{L}^{-1}\right)$

Dec: Decantador

$D_{p}$ : Capacidade de desnitrificação com material orgânico particulado $\left(\mathrm{mgN}^{\mathrm{d}} \mathrm{d}^{-1}\right)$

DP: Desvio Padrão

DQO: Demanda Química de Oxigênio (mg.L-1)

$D_{s}$ : Capacidade de desnitrificação com material orgânico solúvel $\left(\mathrm{mgN}^{-1} \mathrm{~d}^{-1}\right)$

Dt: Capacidade de desnitrificação total de um sistema de lodo ativado

$\mathrm{dX} / \mathrm{dtc}$ : Taxa de crescimento das bactérias nitrificantes (mgSSV.L $\mathrm{L}^{-1} \cdot \mathrm{d}^{-1}$ )

$\mathrm{dX} / \mathrm{dtd}$ : Taxa de decaimento das bactérias nitrificantes $\left(\mathrm{mgSSV}^{-1} \cdot \mathrm{L}^{-1} \cdot \mathrm{d}^{-1}\right)$

$\mathrm{dX} / \mathrm{dte}$ : Taxa de descarga de lodo de excesso $\left(\mathrm{mgSSV}_{\mathrm{L}} \mathrm{L}^{-1} \cdot \mathrm{d}^{-1}\right)$

Efluente: Esgoto efluente após tratamento no sistema de lodo ativado

ETE: Estação de tratamento de esgoto

f aeróbia: Fração aeróbia dos sistemas de lodo ativado operados

f: Fração de lodo orgânico decaído como resíduo endógeno

$\mathrm{fb}_{\mathrm{b}}$ : Fração biodegradável de esgoto 
fbp: Fração biodegradável particulada de esgoto

fbs: Fração biodegradável solúvel de esgoto

$\mathrm{f}_{\mathrm{cv}}$ : Produção de massa bacteriana (gSSV ${ }^{-1} \cdot \mathrm{gDQO}^{-1}$ )

$f_{n}$ : Fração de nitrogênio total Kjeldahl em lodo volátil

fup: Fração de DQO não biodegradável particulada

fus: Fração de DQO não biodegradável solúvel

IVL: Índice volumétrico de lodo

$\mathrm{K}_{\mathrm{d}}$ : Constante de desnitrificação

$\mathrm{K}_{\mathrm{la}}$ : Constante de transferência de oxigênio

$\mathrm{K}_{\mathrm{n}}$ : Constante de meia saturação bactérias autotróficas (mgN.L-1)

$\mathrm{K}_{\mathrm{o}}$ : Constante de meia saturação de oxigênio (mg.L-1)

$\mathrm{K}_{\mathrm{H}}$ : Constante de meia saturação bactérias heterotróficas (mgN.L-1)

$\mathrm{Ks}$ : Constante de meia saturação de substrato $\left(\mathrm{mgS}^{-\mathrm{L}^{-1}}\right)$

MMA: Ministério do Meio Ambiente

MNae: Fluxo de nitrogênio amoniacal efluente $\left(\mathrm{mgN}^{-\mathrm{d}^{-1}}\right)$

MNc: Fluxo da concentração de amônia nitrificada $\left(g N \cdot d^{-1}\right)$

$M N_{d}$ : Fluxo de nitrogênio utilizado na desnitrificação $\left(\mathrm{mgN}^{-1} \mathrm{~d}^{-1}\right)$

$\mathrm{MN}$ : Fluxo de nitrogênio total Kjeldahl no lodo $\left(\mathrm{mgN}^{-\mathrm{d}^{-1}}\right)$

$M N_{n a}$ : Fluxo de nitrato afluente $\left(\mathrm{mgN} \mathrm{d}^{-1}\right)$

$M N_{o e}$ : Fluxo de nitrogênio orgânico efluente $\left(\mathrm{mgN}^{-1} \mathrm{~d}^{-1}\right)$

$M N_{t a}$ : Fluxo de nitrogênio total Kjeldahl afluente $\left(\mathrm{mgN}^{-\mathrm{d}^{-1}}\right)$

$M N_{\text {te }}$ : Fluxo de nitrogênio total Kjeldahl efluente $\left(\mathrm{mgN} \mathrm{d}^{-1}\right)$

MO: Matéria orgânica

$M_{o c}$ : Consumo de oxigênio para oxidação de material orgânico $\left(\mathrm{mgO}^{-1} \mathrm{~d}^{-1}\right)$

$M_{o e q}$ : Oxigênio equivalente recuperado através da desnitrificação $\left(\mathrm{mgO}^{-1} \mathrm{~d}^{-1}\right)$

Mon: Consumo de oxigênio para nitrificação $\left(\mathrm{mgO}^{\mathrm{d}} \mathrm{d}^{-1}\right)$

Mot: Consumo total de oxigênio no reator aeróbio $\left(\mathrm{mgO}^{-1} \mathrm{~d}^{-1}\right)$

$m S_{o}$ : Fração de DQO afluente oxidada no sistema $\left(\mathrm{mgDQO}^{-1} \mathrm{~d}^{-1}\right)$

MSta: Fluxo de DQO afluente $\left(\mathrm{mgDQO}^{-1} \mathrm{~d}^{-1}\right)$

$m S_{\text {te: }}$ Fração de DQO detectada no efluente (mgDQO.d $\left.\mathrm{d}^{-1}\right)$

$m S x v$ : Fração de DQO afluente descarregada no lodo de excesso (mgDQO.d $\left.{ }^{-1}\right)$

MXt: Massa de lodo colocado no cilindro para teste de sedimentabilidade 
$m X_{v}$ : Produção de lodo $\left(\mathrm{mgSSV}^{-1} \cdot \mathrm{mgDQO}^{-1}\right)$

$\mathrm{N}$ : Nitrogênio

$\mathrm{N}_{\mathrm{a}}$ : Concentração de amônia (mgN.L-1)

$\mathrm{N}_{\mathrm{aa}}$ : Concentração de nitrogênio amoniacal afluente $\left(\mathrm{mgN}^{-\mathrm{L}^{-1}}\right)$

$\mathrm{N}_{\mathrm{ae}}$ : Concentração de nitrogênio amoniacal efluente $\left(\mathrm{mgN}^{-\mathrm{L}^{-1}}\right)$

Nc: Concentração de amônia nitrificada (mgN.L-1)

ND: Não detectado pelo método padrão utilizado

NDS: Nitrificação e desnitrificação simultânea

$\mathrm{NH}_{3}$ : Gás amoníaco (mgN.L-1)

$\mathrm{NH}_{4}{ }^{+}$: Íon amônio (mgN.L-1)

Nı: Concentração de NTK para a produção de lodo de excesso (mgN.L-1)

$\mathrm{N}_{\text {na: }}$ : Concentração de nitrogênio nitrato afluente $\left(\mathrm{mgN}^{\left.\left.-L^{-1}\right)\right)}\right.$

$\mathrm{N}_{\mathrm{ne}}$ : Concentração de nitrato no efluente $\left(\mathrm{mgN} . \mathrm{L}^{-1}\right)$

$\mathrm{N}-\mathrm{NO}_{2}$ : Nitrito $\left(\mathrm{mgN}^{-L^{-1}}\right)$

$\mathrm{N}-\mathrm{NO}_{3}:$ : Nitrato $\left(\mathrm{mgN}^{-1}\right)$

$\mathrm{N}_{0}$ : Material nitrogenado inicial referente a recirculações $\left(\mathrm{mgN}^{-1} \mathrm{~L}^{-1}\right)$

$\mathrm{N}_{\mathrm{oa}}$ : Concentração de nitrogênio orgânico afluente $\left(\mathrm{mgN} \mathrm{L}^{-1}\right)$

Noe: Concentração de nitrogênio orgânico efluente $\left(\mathrm{mgN}^{\mathrm{L}} \mathrm{L}^{-1}\right)$

N-Orgânico: Nitrogênio Orgânico (mgN.L-1)

$\mathrm{N}_{\text {ta: }}$ : Concentração de NTK afluente $\left(\mathrm{mgN}^{-L^{-1}}\right)$

$\mathrm{N}_{\mathrm{te}}$ : Concentração de NTK efluente $\left(\mathrm{mgN} . \mathrm{L}^{-1}\right)$

NTK: Concentração de nitrogênio total Kjeldahl $\left(\mathrm{mgN}^{-1} \mathrm{~L}^{-1}\right)$

OD: Concentração de oxigênio dissolvido (mg. $\left.\mathrm{L}^{-1}\right)$

ODmáx: Valor de oxigênio dissolvido de referência superior $\left(m g . L^{-1}\right)$

ODmin: Valor de oxigênio dissolvido de referência inferior $\left(\mathrm{mg}^{\mathrm{L}} \mathrm{L}^{-1}\right)$

OLAND: Oxygen Limited Autotrophic Nitrification Denitrification

$\mathrm{pH}$ : Potencial hidrogeniônico

PROSAB: Programa de Saneamento Básico

q: Volume de licor misto a ser descartado $\left(\right.$ L.d $\left.^{-1}\right)$

Qa: Vazão afluente $\left(\right.$ L.d $\left.^{-1}\right)$

$Q_{e}$ : Vazão efluente $\left(L \cdot d^{-1}\right)$

Qra: Vazão de recirculação "a" (L.d $\left.{ }^{-1}\right)$ 
r: Taxa de recirculação de licor misto

RBS: Reator em bateladas sequenciais

rd: Taxa de desnitrificação

rdp: Taxa de desnitrificação para material lentamente biodegradável

rds: Taxa de desnitrificação para material rapidamente biodegradável

$\mathrm{R}_{\mathrm{h}}$ : Tempo de permanência do líquido $\left(\mathrm{d}^{-1}\right)$

rmáx: Taxa de utilização máxima material carbonáceo $\left(\mathrm{mgDQO} \mathrm{mgX}^{-1} \cdot \mathrm{d}^{-1}\right)$

rn.máx: Taxa de utilização máxima de amônia, nitrito ou nitrato

$\mathrm{R}_{\mathrm{s}}$ : Idade de lodo $\left(\mathrm{d}^{-1}\right)$

$\mathrm{R}_{\mathrm{sm}}$ : Idade de lodo mínima para que ocorra nitrificação

rus: Taxa de utilização de material rapidamente biodegradável

S: Concentração de substrato (mg. $\left.\mathrm{L}^{-1}\right)$

S32c: Software do respirômetro Beluga

Sba: DQO biodegradável afluente $\left(\mathrm{mg} \cdot \mathrm{L}^{-1}\right)$

Sbpa: DQO biodegradável particulada afluente $\left(\mathrm{mg}^{-\mathrm{L}^{-1}}\right)$

Sbsa: DQO biodegradável solúvel afluente $\left(\mathrm{mg} \cdot \mathrm{L}^{-1}\right)$

SHARON: Single-reactor High-activity Ammonium Removal Over Nitrite

SS: Sólidos suspensos (mg. $\left.\mathrm{L}^{-1}\right)$

SSF: Sólidos suspensos fixos (mg. $\left.\mathrm{L}^{-1}\right)$

SST: Sólidos suspensos totais (mg. $\left.\mathrm{L}^{-1}\right)$

SSV: Sólidos suspensos voláteis $\left(\mathrm{mg} \cdot \mathrm{L}^{-1}\right)$

Sta: DQO afluente $\left(\mathrm{mg}^{\mathrm{L}} \mathrm{L}^{-1}\right)$

Ste: DQO efluente (mg. $\left.\mathrm{L}^{-1}\right)$

Sua: DQO não biodegradável afluente $\left(\mathrm{mg} \cdot \mathrm{L}^{-1}\right)$

Supa: DQO não biodegradável particulada afluente $\left(\mathrm{mg}^{\mathrm{L}} \mathrm{L}^{-1}\right)$

Susa: DQO não biodegradável solúvel afluente $\left(\mathrm{mg}^{\mathrm{L}} \mathrm{L}^{-1}\right)$

$\mathrm{T}$ : Temperatura $\left({ }^{\circ} \mathrm{C}\right)$

TCO "in loco": Taxa de consumo de oxigênio real do sistema $\left(\mathrm{mgO}_{2} \cdot \mathrm{L}^{-1} \cdot \mathrm{h}^{-1}\right)$

TCO: Taxa de consumo de oxigênio $\left(\mathrm{mgO}_{2} \cdot \mathrm{L}^{-1} \cdot \mathrm{h}^{-1}\right)$

TCOend: Taxa de Consumo de Oxigênio endógena $\left(\mathrm{mgO}_{2} \cdot \mathrm{L}^{-1} \cdot \mathrm{h}^{-1}\right)$

TCOeq: Taxa de consumo de oxigênio equivalente $\left(\mathrm{mgO}_{2} \cdot \mathrm{L}^{-1} \cdot \mathrm{h}^{-1}\right)$

TCOexo: Taxa de consumo de oxigênio exógena $\left(\mathrm{mgO}_{2} \cdot \mathrm{L}^{-1} \cdot \mathrm{h}^{-1}\right)$ 
TCOexomáx: Taxa de consumo de oxigênio exógena máxima $\left(\mathrm{mgO}_{2} \cdot \mathrm{L}^{-1} \cdot \mathrm{h}^{-1}\right)$

TCOn: TCO total devido à nitrificação $\left(\mathrm{mgO}_{2} \cdot \mathrm{L}^{-1} \cdot \mathrm{h}^{-1}\right)$

TCOn.máxima: TCO total devido à nitrificação máxima $\left(\mathrm{mgO}_{2} \cdot \mathrm{L}^{-1} \cdot \mathrm{h}^{-1}\right)$

TCO total: Taxa de consumo de oxigênio total $\left(\mathrm{mgO}_{2} \cdot \mathrm{L}^{-1} \cdot \mathrm{h}^{-1}\right)$

TDH: Tempo de detenção hidráulica $(\mathrm{h})$

UCT: University of Cape Town

USP: Universidade de São Paulo

$V_{r}$ : Volume do reator $\left(\mathrm{L}^{-1}\right)$

$\mathrm{V}_{\mathrm{T}}$ : Volume total $\left(\mathrm{L}^{-1}\right)$

Vu: Volume útil $\left(\mathrm{L}^{-1}\right)$

X: Concentração ativa das bactérias $\left(\mathrm{mgX.L^{-1 } )}\right.$

$\mathrm{X}_{\mathrm{a}}$ : Concentração ativa das bactérias heterotróficas $\left(\mathrm{mgX}_{\mathrm{a}} \cdot \mathrm{L}^{-1}\right)$

$\mathrm{X}_{\mathrm{e}}$ : Concentração de resíduo endógeno $\left(\mathrm{mg} \cdot \mathrm{L}^{-1}\right)$

$\mathrm{X}_{\mathrm{F}}$ : Concentração de sólidos fixos $\left(\mathrm{mg} \cdot \mathrm{L}^{-1}\right)$

$\mathrm{X}_{\mathrm{i}}$ : Concentração de resíduo inerte $\left(\mathrm{mg} \cdot \mathrm{L}^{-1}\right)$

$X_{n}$ : Concentração ativa de bactérias nitrificantes $\left(\mathrm{mgX}_{\mathrm{n}} \mathrm{L}^{-1}\right)$

$\mathrm{X}_{\mathrm{t}}$ : Concentração de lodo (gSTS.L-1)

$\mathrm{Xv}$ : Concentração de sólidos voláteis $\left(\mathrm{mg} \cdot \mathrm{L}^{-1}\right)$

$Y_{n}$ : Coeficiente de rendimento das bactérias autotróficas $\left(m g N \cdot L^{-1} \cdot d^{-1}\right)$

$\theta$ : Coeficiente de dependência da temperatura - Arrehnius 
1. INTRODUÇÃO

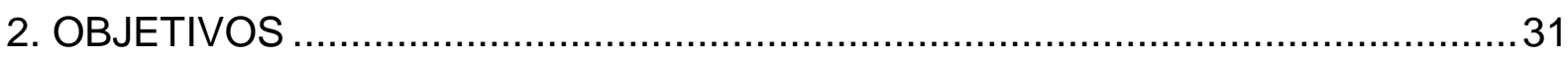

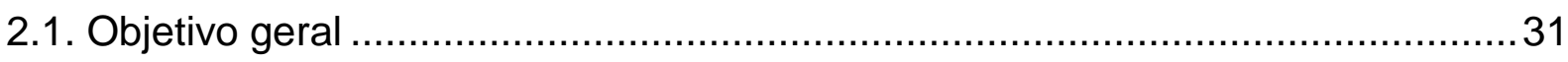

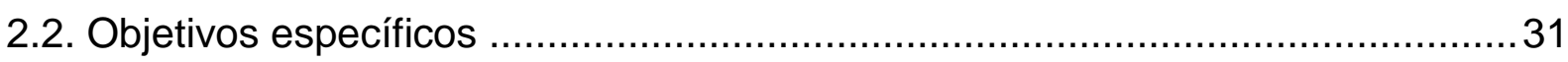

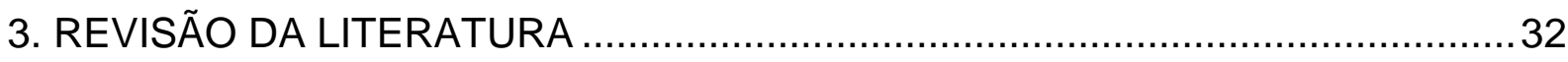

3.1. Introdução aos processos de eliminação de nitrogênio......................................32

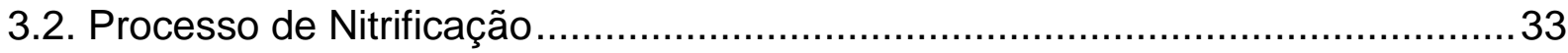

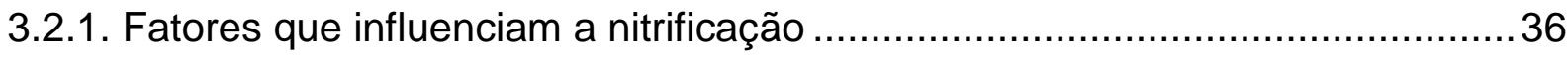

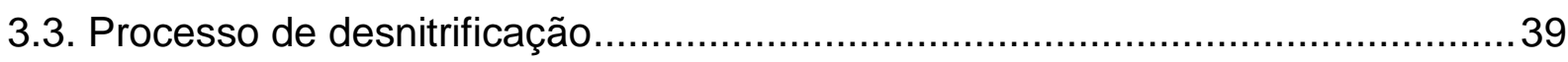

3.3.1. Fatores que influenciam e Condições necessárias para desnitrificação ..........41

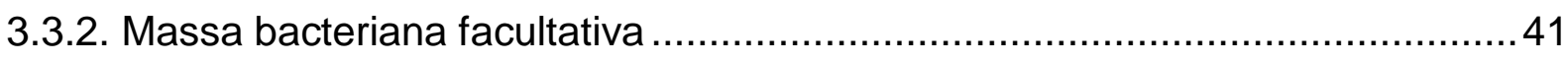

3.3.3. Presença de nitrato e ausência de OD.................................................... 41

3.3.4. Condições ambientais adequadas para os microrganismos ......................... 42

3.3.5. Estequiometria das reações do material nitrogenado ..................................... 43

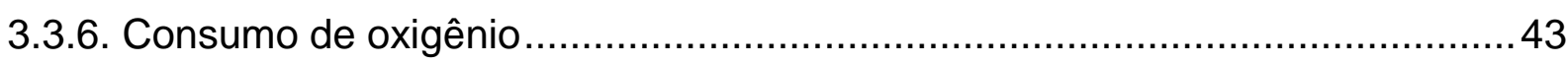

3.4. Variação da alcalinidade no processo de amonificação, nitrificação e

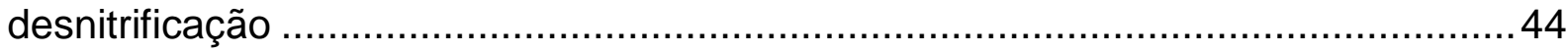

3.5. Possibilidades de impacto do ciclo do nitrogênio na atmosfera .........................48

3.5.1. O óxido nitroso nas águas residuárias e a emissão de $\mathrm{N}_{2} \mathrm{O}$ em processos de

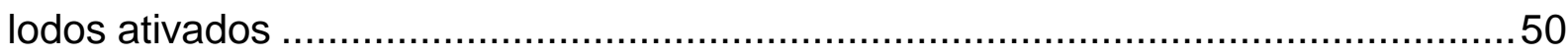

3.6. Generalidades sobre o processo de lodos ativados ....................................... 51

3.6.1. Processos biológicos para remoção de nitrogênio ……………....................53

3.6.2. Sistema de Lodos Ativados com pré-nitrificação .......................................... 53

3.6.3. Sistema de Lodos Ativados com pós-nitrificação ............................................54

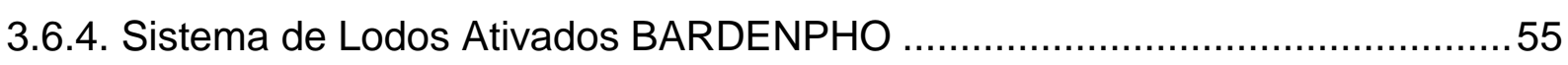

3.6.5. Sistema de Lodos Ativados UCT (University of Cape Town) ..........................56

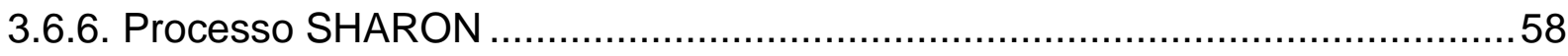

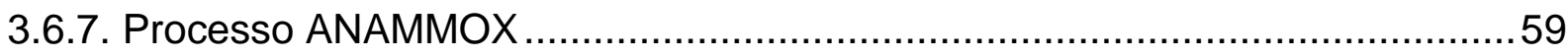

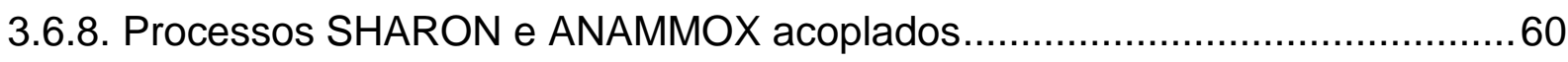

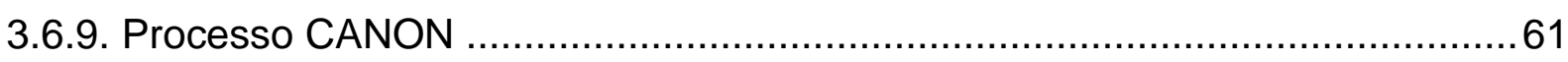

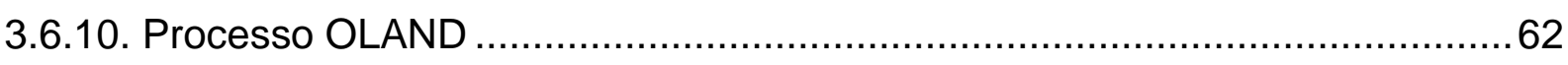

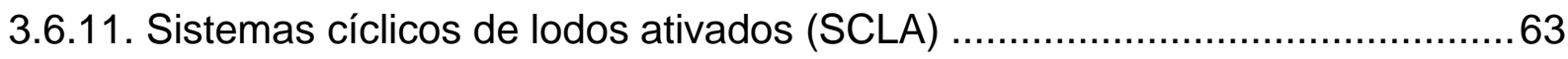


3.6.12. Reatores de leito móvel com biofilme (MBBR - Moving-bed biofilm reactor) 66

3.6.13. Lodo granular aeróbio (AGS - Aerobic granular sludge).

3.7. Nitrificação e Desnitrificação Simultânea (NDS) em processos de lodos ativados .70

3.7.1. Fundamentos .70

3.7.2. Condições necessárias para nitrificação e desnitrificação simultânea .70

3.7.3. Principais sistemas de remoção biológica de nitrogênio pelo processo de NDS. .77

3.7.4. Valo de oxidação com baixa concentração de OD e monitoramento Sym-BioTM .78

3.7.5. Sistema de lodo ativado com diferentes concentrações de OD do tipo OrbalTM 79

3.7.6. Sistema de lodos ativados por aeração prolongada de fluxo contínuo 81

3.7.6.2. Otimização do processo de lodos ativados com aeração prolongada para o desenvolvimento da NDS

3.8. Modelo cinético da remoção dos compostos orgânicos no processo de lodos ativados

3.8.1. Cinética do processo de remoção de material orgânico. .83

3.8.2. Balanço de massa de material orgânico. .84

3.8.3. Fatores cinéticos da utilização de material orgânico 84

3.9. Modelo cinético da remoção dos compostos nitrogenados no processo de lodos ativados

4. MATERIAIS E MÉTODOS 93

4.1. Localização da Estação de Tratamento de Esgoto da SABESP ETE - LIMOEIRO .93

4.2. Características principais da ETE Limoeiro da SABESP. .93

4.2.1. A ETE Limoeiro existente é composta de:. .94

4.2.2. Gradeamento, estação elevatória e desarenação .....................................94

4.2.3. Estação Elevatória de Esgoto Bruto .....................................................95

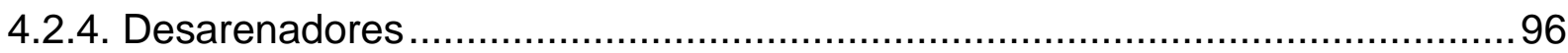

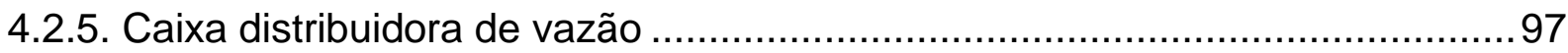

4.2.6. Características dos tanques e do sistema de aeração da ETE Limoeiro ........98

4.2.7. Sistema de aeração e mistura do lodo ativado.......................................98

4.2.8. Fornecimento e controle da aeração .....................................................99

4.2.9. Características dos controladores e sensores de monitoramento online de OD, $\mathrm{pH}$, REDOX e Nitrato implantados na ETE Limoeiro. 


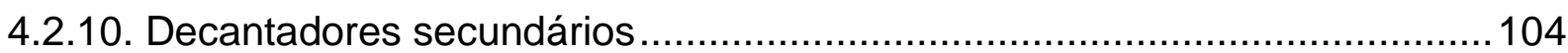

4.2.11. Estação Elevatória de Recirculação de Lodo ..........................................105

4.2.12. Adensamento do excesso de lodo ativado ............................................. 106

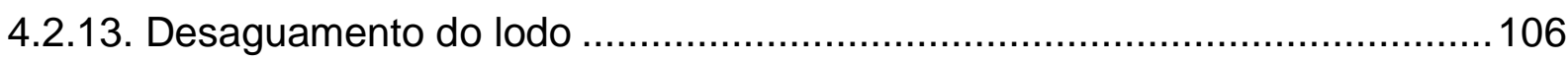

4.2.14. Pátio para estocagem do lodo desidratado .............................................. 108

4.2.15. Desinfecção do esgoto tratado ......................................................... 108

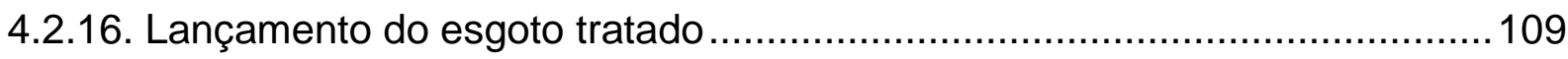

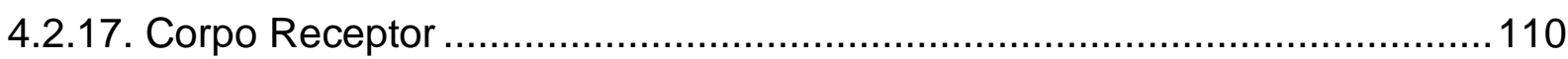

4.3. Procedimentos Operacionais Rotineiros ……….......................................110

4.3.1. Determinação das Características do Afluente e dos Efluentes .....................110

4.3.1.2. Variáveis Controladas, Pontos de Amostragem e Frequências ..................111

4.3.2. Monitoramento do óxido nitroso no processo de lodos ativados ..................112

4.3.3. Determinação das Características dos Lodos dos Reatores Biológicos .......114

4.3.3.1. Variáveis Controladas, Pontos de Amostragem e Frequências .................114

4.3.4. Determinação da velocidade de sedimentação do lodo ...............................115

4.3.5. Caracterização morfológica do floco de lodo ativado por meio de programas

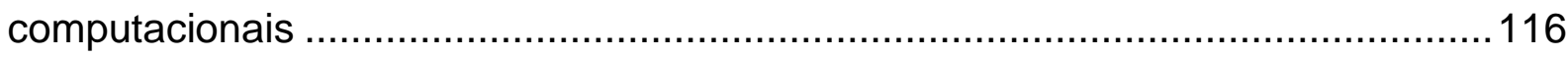

4.3.6 Medição da TCO total "in loco" no processo de lodos ativados......................118

4.3.7 Balanços de massa do material orgânico e nitrogenado ................................119

4.3.7.1 Balanço de massa do material orgânico..................................................119

4.3.7.2. Balanço de massa do material nitrogenado ........................................... 119

4.3.8. Uso da Respirometria para determinação das constantes cinéticas da

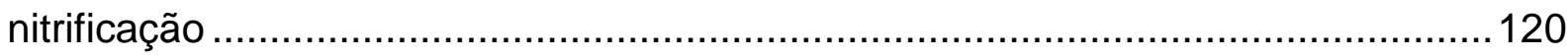

4.3.8.1. Investigação experimental da atividade bacteriana autotrófica .................. 122

4.3.8.2. Estimativa das constantes de crescimento específico $(\mu \mathrm{m})$, constante de meia saturação de Monod ( $\mathrm{Kn}$ ) e da taxa máxima de nitritação e nitratação (rn.max). ...126

4.3.8.3. Frações biodegradáveis de matéria orgânica do esgoto sanitário ..............129

4.3.8.4. Investigação experimental da atividade bacteriana heterotrófica ............... 131

4.3.9. Caracterização dos grupos de microrganismos atuantes no processo por

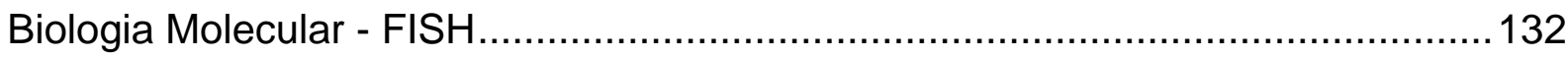

4.4. Estação de tratamento de esgoto em escala piloto .........................................132

5. APRESENTAÇÃO DOS RESULTADOS E DISCUSSÕES ..............................135

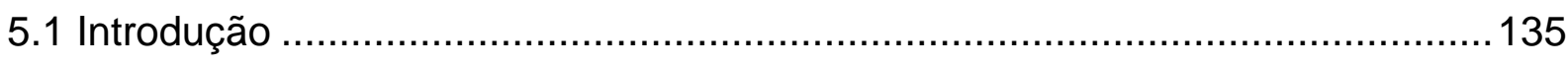

5.2 CONTROLE LABORATORIAL E MONITORAMENTO ONLINE DAS PRINCIPAIS VARIÁVEIS EXERCIDAS NO PROCESSO DE LODO ATIVADO ........................135 
5.2.1 Vazão de esgoto da ETE Limoeiro

5.2.2 Concentrações de sólidos nos tanques de aeração no processo de lodos ativados

5.2.3 Sólidos em suspensão totais no esgoto à saída do processo de lodos ativados

5.2.4 Idade do lodo ativado 140

5.2.5 Índice volumétrico do lodo 142

5.2.6 Determinação da velocidade de sedimentação do lodo 143

5.2.7 Caracterização morfológica dos flocos do lodo ativado 148

5.2.8 Concentrações de OD nos tanques de aeração. 149

5.2.9 Temperatura do lodo ativado nos tanques de aeração 152

$5.2 .10 \mathrm{pH}$ do lodo ativado nos tanques de aeração 155

5.2.11 Potencial de oxirredução 158

5.3 Remoção de Material Orgânico 160

5.3.1 Resultados da DBO no esgoto à entrada e à saída do processo de lodos ativados 160

5.3.2 Resultados da DQO no esgoto à entrada e à saída do processo de lodos ativados 164

5.3.3 Balanço de Massa do Material Orgânico 168

5.4 Remoção de Nitrogênio 171

5.4.1 Nitrato 175

5.4.2 Resultados do balanço de massa do material nitrogenado 179

5.4.3 Monitoramento do óxido nitroso no processo de lodos ativados 182

5.4.4 Variação da alcalinidade devido a amonificação, nitrificação e desnitrificação no processo de lodo ativado 184

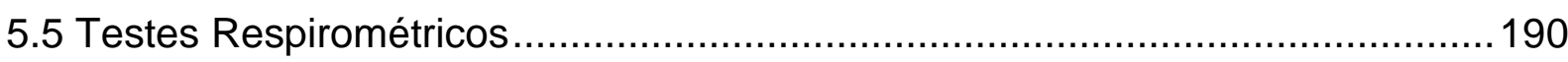

5.5.1 Resultados das frações de matéria orgânica no esgoto sanitário afluente ....190

5.5.2 Atividade Metabólica das Bactérias Heterotróficas. 191

5.5.3 Verificação do balanço de massa para validação do teste respirométrico sob baixas concentrações de oxigênio dissolvido ......................................................193

5.5.4 Constantes cinéticas das bactérias autotróficas nitritantes e nitratantes ....... 194

5.6 Biologia Molecular aplicada ao processo de lodos ativados............................ 198

5.7 Uso de energia para aeração do processo de lodos ativados ............................199 
5.8 CONTROLE LABORATORIAL E MONITORAMENTO DAS PRINCIPAIS VARIÁVEIS EXERCIDAS NO PROCESSO DE LODO ATIVADO DA ETE PILOTO 202

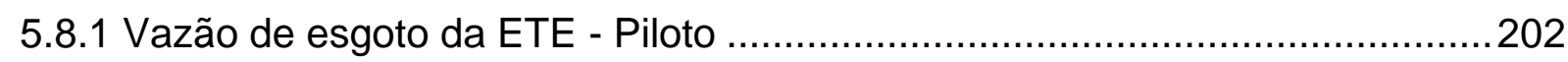

5.8.2 Sólidos em suspensão totais no efluente da ETE ......................................204

5.8.3 Índice volumétrico do lodo nos tanques de aeração .....................................206

5.8.4 Concentrações de OD nos tanques de aeração...........................................206

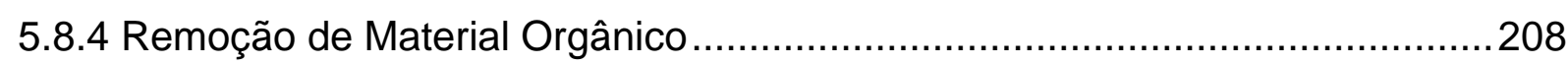

5.8.4.1 Resultados da DBO no afluente e efluente do sistema de lodo ativado ......208

5.8.4.2 Balanço de Massa do Material Orgânico .................................................210

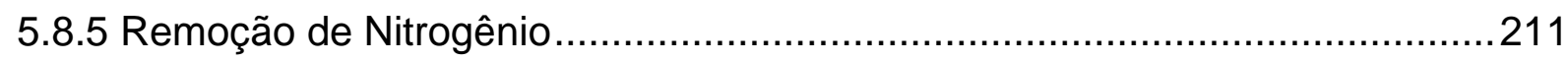

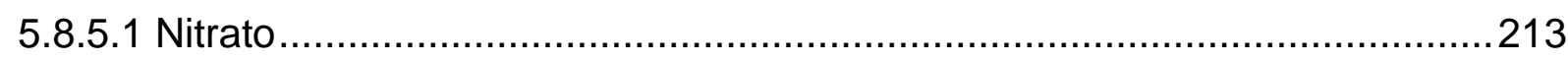

5.8.5.2 Resultados do balanço de massa do material nitrogenado ........................214

5.8.5.3 Variação da alcalinidade devido a amonificação, nitrificação e desnitrificação no processo de lodo ativado da ETE Piloto......................................................215

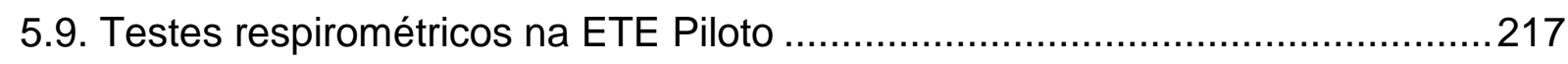

5.9.1. Atividade Metabólica das Bactérias Heterotróficas. ...................................217

5.9.2. Constantes cinéticas das bactérias autotróficas nitritantes e nitratantes ......218

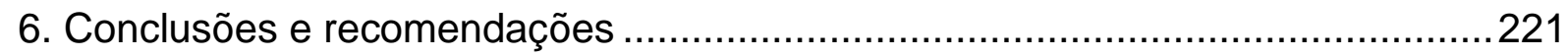

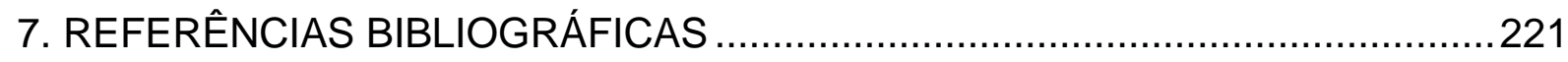




\section{INTRODUÇÃO}

Os sistemas de lodos ativados se distinguem de outros sistemas de tratamento biológico de esgotos por oferecerem a possibilidade de se remover de águas residuárias, os nutrientes nitrogênio e fósforo com requisitos mínimos de área. Para dispor das vantagens desses sistemas, quanto à remoção de nutrientes, podem-se variar suas configurações e, dessa maneira, elevar o seu potencial de tratamento. Grande parte do lodo em sistemas de lodo ativado se compõe de bactérias heterotróficas facultativas, isto é, bactérias que usam o material orgânico como fonte de energia, utilizando oxigênio como aceptor final de elétrons. Todavia, quando em situações onde o oxigênio não está presente, essas bactérias são capazes de utilizar a energia contida no material orgânico, através da fermentação, ou utilizar outro oxidante como aceptor final de elétrons, por exemplo, nitrato ou nitrito. Quando nitrato ou nitrito são utilizados pelas bactérias heterotróficas facultativas como oxidante da matéria orgânica, ocorre a remoção de nitrogênio como gás $\left(N_{2}\right)$ num processo denominado de desnitrificação (VAN HAANDEL e MARAIS, 1999). O processo de desnitrificação contribui para mitigar o problema de eutrofização nos corpos d'água receptores. Esse processo se deve, principalmente, a atuação de bactérias quimiorganotróficas, e fototróficas e de alguns fungos. De forma geral, a desnitrificação é precedida pela nitrificação que é um processo realizado comumente por organismos autotróficos nitrificantes. Em regiões de clima tropical, a nitrificação, mesmo que não tenha sido prevista em projeto, quase sempre acontece. Por esse motivo, a desnitrificação deve estar inserida no projeto original de dimensionamento para que problemas operacionais graves não ocorram, como por exemplo, a flotação do lodo no decantador secundário devido à liberação de nitrogênio gasoso (VAN HAANDEL e MARAIS, 1999). O processo de lodo ativado com aeração prolongada possui uso bastante difundido para o tratamento dos esgotos de comunidades de diversos portes, tanto sob fluxo contínuo como intermitente. Apresenta eficiência elevada na remoção de matéria orgânica biodegradável, podendo garantir também a remoção biológica do nitrogênio. Pode ser adaptado para a remoção de fósforo e o alto grau de clarificação do efluente viabiliza o processo de desinfecção final de forma eficiente. O principal aspecto negativo é o seu custo operacional elevado, sobrecarregado principalmente pelo grande consumo de energia e pela alta produção 
de lodo, relativamente a outros processos. Recentemente, foi desenvolvido e implantado em algumas ETE's europeias, o processo conhecido por Simultaneous Nitrification and Denitrification (SND), em que um sistema de lodo ativado com aeração prolongada tem o seu sistema rigidamente controlado, de forma a manter-se valores sempre baixos de concentração de oxigênio dissolvido nos tanques de aeração, por exemplo, em torno de $0,5 \mathrm{mgO} / \mathrm{L}$. Ainda assim a nitrificação será possível, desde que se tenha tempo de retenção de sólidos elevados e, de acordo com a teoria, nestas condições o interior do floco biológico se mantém anóxico, ocorrendo a desnitrificação. Assim, além da incorporação do importante benefício da remoção de nitrogênio, o consumo de energia é menor, tanto pela manutenção de concentração baixa de OD nos tanques de aeração, tanto pelo consumo de carga orgânica sob condições anóxicas. As ETE's por lodos ativados com aeração prolongada existentes podem ser adaptadas para a nitrificação e desnitrificação simultâneas, merecendo maior aprofundamento sobre o conhecimento teórico e sobre o comportamento prático deste processo. Alguns estudos demonstram a possibilidade de se obter a nitrificação e a desnitrificação do esgoto simultaneamente em lodo ativado de fluxo contínuo com elevadas eficiências (PENG ZHANG E ZHOU QI, 2007; THAURÉ et al., 2008; BUENO, 2011). Dentro deste contexto, esta pesquisa teve por objetivo a produção de elementos para a avaliação da viabilidade de se agregar novas tecnologias a uma estação de tratamento de esgoto sanitário pelo processo de lodo ativado com aeração prolongada em escala real, visando a remoção de nitrogênio e redução de energia elétrica para aeração. 


\section{OBJETIVOS}

\subsection{Objetivo geral}

O objetivo central da pesquisa é a proposição de medidas para a melhoria das condições operacionais de estações de tratamento de esgoto operadas pelo processo de lodos ativados com aeração prolongada, de forma a obter-se a remoção de nitrogênio do esgoto por meio do processo de nitrificação e desnitrificação simultânea (NDS) e redução no custo de energia para aeração.

\subsection{Objetivos específicos}

Como objetivos específicos apresentam-se:

(1) Avaliação dos resultados da operação do processo de lodos ativados sob baixa idade do lodo e baixa concentração residual de OD nos tanques de aeração, em termos de remoção de matéria orgânica e nitrogênio, da estabilidade geral do processo biológico, da conformação morfológica e ocorrência de eventuais problemas na sedimentabilidade do lodo, dentre outros. Com isto será possível também avaliar a confiabilidade operacional do processo de tratamento e a redução no consumo de energia elétrica que poderá ser obtido.

(2). Utilizar o modelo simplificado da teoria de lodo ativado, descrito por VAN HAANDEL e MARAIS (1999) para a determinação da cinética das bactérias nitrificantes, desnitrificantes e demais heterotróficas; 


\section{REVISÃO DA LITERATURA}

\subsection{Introdução aos processos de eliminação de nitrogênio}

O nitrogênio pode apresentar-se na forma de muitos compostos devido ao seu alto número de estados oxidativos. No meio ambiente, o nitrogênio encontra-se mais frequentemente na forma de amônia $\left(\mathrm{NH}_{3}\right)$, amônio $\left(\mathrm{NH}_{4}{ }^{+}\right)$, nitrato $\left(\mathrm{NO}_{3}^{-}\right)$ou nitrogênio gasoso $\left(\mathrm{N}_{2}\right)$. A equação de equilíbrio amônia-amônio está representada sob a forma $\mathrm{NH}_{4}{ }^{+} \leftrightarrow \mathrm{NH}_{3}+\mathrm{H}^{+}$. De acordo com o princípio de Le Chatelier, para valores ácidos de $\mathrm{pH}$, a concentração de $\mathrm{H}^{+}$aumenta, e o equilíbrio está deslocado para a esquerda, havendo predominância do íon amônio; para valores básicos de pH, a concentração de $\mathrm{H}^{+}$diminui e o equilíbrio deslocado para a direita, sendo a amônia predominante neste último caso. As substâncias orgânicas nitrogenadas podem ser degradadas por bactérias decompositoras gerando $\mathrm{NH}_{3}$, enquanto que o nitrogênio gasoso presente na atmosfera pode ser convertido em $\mathrm{NH}_{3}$ através da atuação das bactérias fixadoras de nitrogênio (HENZE et al., 1997, MADIGAN et al., 1997). A Figura 1 representa as possíveis conversões entre compostos nitrogenados, as quais fazem parte do ciclo do nitrogênio na natureza.

Figura 1: Conversões possíveis entre compostos nitrogenados

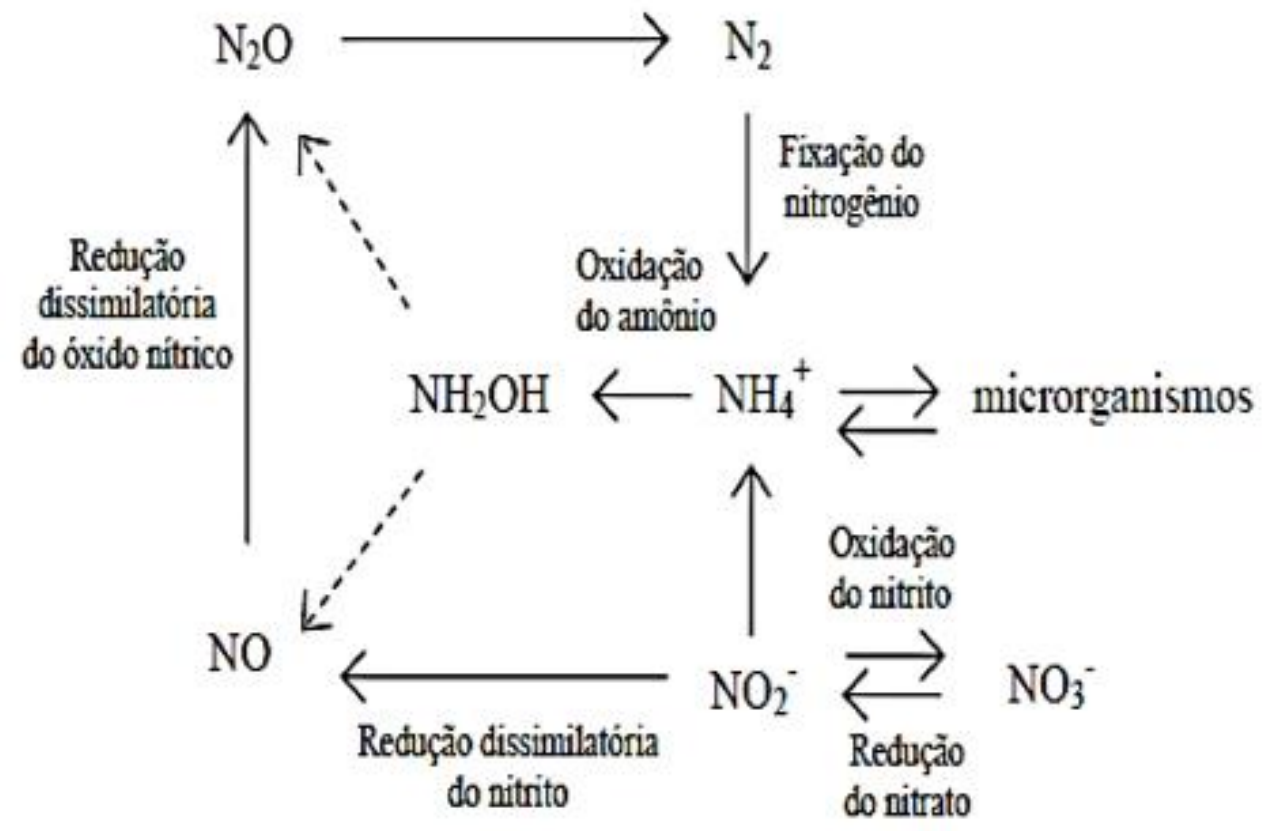


Tradicionalmente, a eliminação de nitrogênio de águas residuárias são por meio de processos que envolvem as etapas de nitrificação e desnitrificação. Como exposto nos itens anteriores, na nitrificação a amônia (ou amônio) passa a nitrato, sob condições aeróbias, tendo o oxigênio como substância que aceita elétrons transportados na cadeia respiratória, permitindo a reoxidação das coenzimas e a geração de ATP; e na desnitrificação, o nitrato é convertido a nitrogênio gasoso $\left(\mathrm{N}_{2}\right)$, tendo como possíveis intermediários o óxido nítrico $(\mathrm{NO})$ e óxido nitroso $\left(\mathrm{N}_{2} \mathrm{O}\right)$, sendo estes igualmente lançados na atmosfera. A desnitrificação é realizada sob condições anaeróbicas, tendo o nitrato como substância aceptora de elétrons (MADIGAN et al., 1997; UEMOTO e SAIKI, 2000).

\subsection{Processo de Nitrificação}

A nitrificação é entendida como a etapa limitante do processo convencional de remoção de nitrogênio, consistindo também na etapa mais estudada e para a qual se encontra a maior abundância de informações, além de ser de vital importância para os novos processos de tratamento. O processo nitrificante é realizado pela ação de dois grupos de bactérias. O primeiro grupo, predominantemente pertencendo ao gênero Nitrosomonas, é responsável pela nitritação, isto é, a oxidação da amônia a nitrito. Já o segundo grupo, pertencendo predominantemente ao gênero Nitrobacter, promove a conversão do nitrito em nitrato, etapa designada por nitratação (RAMALHO, 1983; METCALF \& EDDY, 2013). A Figura 2 mostra uma imagem de microscopia eletrônica desses grupos de bactérias.

Figura 2: Bactérias Nitrosomonas sp. e Nitrobacter sp.

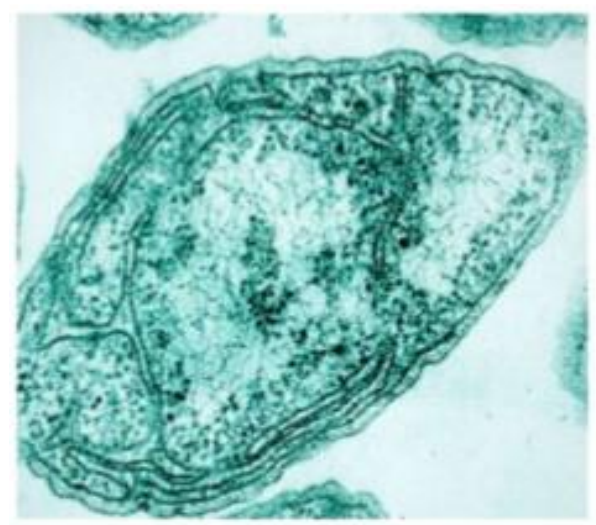

Nitrosomonas

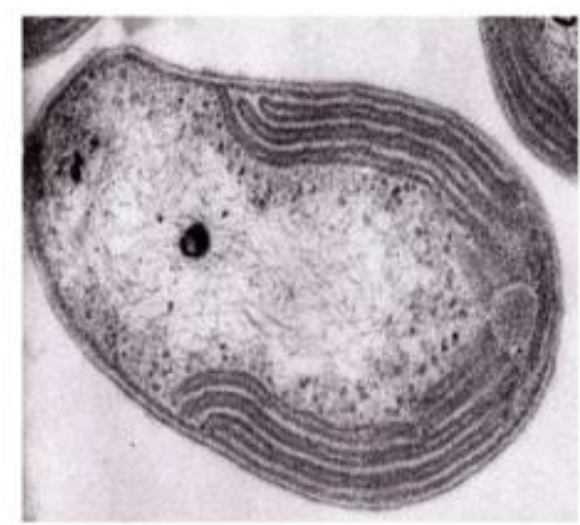

Nitrobacter 
Segundo Wiesmann (1994) apud Schmidell e Reginatto (2005), as linhagens mais importantes para a nitrificação seriam Nitrosomonas europaea e Nitrobacter winogradskyi. Entretanto, existem outros gêneros e espécies que podem figurar neste processo. Na nitritação, podem estar envolvidas outras espécies do gênero Nitrosomonas e do gênero Nitrosococcus. Já para a nitratação, pode-se citar Nitrobacter winogradsky, Nitrocystis sp., Nitrococcus sp., Nitrospina sp. e Nitrobacter agilis (SEDLAK, 1991 apud METCALF \& EDDY).

As etapas do processo nitrificante estão descritas através das equações 1, 2 e 3, a seguir (HENZE et al., 1997, MADIGAN et al., 1997).

Geração de nitrito:

$\mathrm{NH}_{4}+{ }^{+}(3 / 2) \mathrm{O}_{2} \rightarrow \mathrm{NO}_{2}^{-}+\mathrm{H}_{2} \mathrm{O}+2 \mathrm{H}^{+}$

Geração de nitrato:

$\mathrm{NO}_{2}^{-}+(1 / 2) \mathrm{O}_{2} \rightarrow \mathrm{NO}_{3}^{-}$

Reação global:

$\mathrm{NH}_{4}{ }^{+}+2 \mathrm{O}_{2} \rightarrow \mathrm{NO}_{3}{ }^{-}+2 \mathrm{H}^{+}+\mathrm{H}_{2} \mathrm{O}$

A liberação de energia livre da reação (1) está situada entre 58 e $84 \mathrm{kcal}^{\mathrm{mol}}{ }^{-1}$ de íon amônio. Em contrapartida, a reação (2) libera energia compreendida na faixa de 15,4 a $20,9 \mathrm{kcal} . \mathrm{mol}^{-1}$ de nitrito. Pela estequiometria das reações (1) e (2), pode-se verificar que a massa de oxigênio necessária para completar essas reações é de 4,57 gO//gN oxidado, sendo $3,43 \mathrm{~g}$ de $\mathrm{O}_{2}$ necessária para a oxidação do nitrogênio amoniacal e 1,14 g para a oxidação do nitrito. Os potenciais redox (Eh) do par $\mathrm{NH}_{2} \mathrm{OH} / \mathrm{NH}_{4}{ }^{+}$da primeira reação e do par $\mathrm{NO}_{3}-\mathrm{NO}_{2}{ }^{-}$da segunda reação, correspondem a 0 e +0.43 volts, respectivamente. São valores bastante elevados, fazendo com que as bactérias doem elétrons para sua cadeia de transporte de elétrons somente em etapas mais adiantadas do processo global. Desta forma, limita-se a geração de ATP, acarretando crescimento lento (MADIGAN et al. 1997). As baixas velocidades de crescimento 
celular apresentadas pelos microrganismos nitrificantes chegam a ser problemáticas, tendo em vista que pouca biomassa é produzida, o que contribui para o aumento da sensibilidade do processo (SORIA E CHAVARRIA, 1978; HÄNEL, 1988 apud BASSIN, 2012).

No estudo de Henze et. al., 1997 os autores propuseram as seguintes reações para as duas etapas da nitrificação, em termos de crescimento celular:

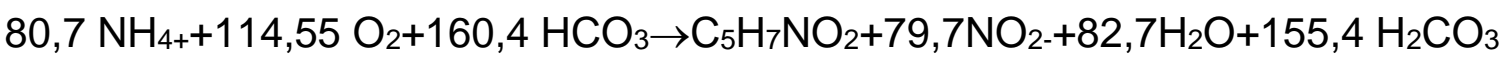

$134,5 \mathrm{NO}_{2-}+\mathrm{NH}_{4+}+62,25 \mathrm{O}_{2}+\mathrm{HCO}_{3-}+4 \mathrm{H}_{2} \mathrm{CO}_{3} \rightarrow \mathrm{C}_{5} \mathrm{H}_{7} \mathrm{NO}_{2}+134,5 \mathrm{NO}_{3-}+3 \mathrm{H}_{2} \mathrm{O}$

\section{A reação final seria:}

$\mathrm{NH}_{4+}+1,86 \mathrm{O}_{2}+1,98 \mathrm{HCO}_{3} \rightarrow 0,020 \mathrm{C}_{5} \mathrm{H}_{7} \mathrm{NO}_{2}+0,98 \mathrm{NO}_{3-}+1,88 \mathrm{H}_{2} \mathrm{CO}_{3}+1,04 \mathrm{H}_{2} \mathrm{O}$

Da reação (4), pode-se verificar que são gerados $113 \mathrm{~g}$ de células (designadas pela fórmula empírica $\mathrm{C}_{5} \mathrm{H}_{7} \mathrm{NO}_{2}$ ), pela conversão de $1129,8 \mathrm{~g} \mathrm{NH}_{4+}$, o que implica em um fator de conversão de substrato a células equivalente a $0,10 \mathrm{~g} \mathrm{SSV} \cdot \mathrm{g}^{-1} \mathrm{~N}-\mathrm{NH}_{4}{ }^{+}$. A partir da reação final (6), pode-se também calcular o mesmo fator de conversão, agora para todo o conjunto microbiano atuante no processo, resultando em $0,16 \mathrm{SSV} . \mathrm{g}^{-1} \mathrm{~N}-\mathrm{NH}_{4}+$, sendo, desse total, 0,06 gSSV.g-1 N-NH${ }_{4}^{+}$a parcela representativa à nitratação (SCHMIDELL e REGINATTO, 2005). As bactérias atuantes no processo nitrificante são autotróficas, e utilizam carbono inorgânico $\left(\mathrm{CO}_{2}\right)$ para a síntese celular. Desta forma, independem de compostos orgânicos pré-formados como fontes de carbono. São igualmente denominadas quimiolitotróficas, pois oxidam compostos inorgânicos para obtenção de energia (METCALF \& EDDY, 2013). A eficiência dos processos de controle de nitrogênio depende tanto da habilidade dos organismos nitrificantes em oxidar amônia a nitrato como também de fatores como $\mathrm{pH}$, temperatura, oxigênio dissolvido e compostos inibidores (ANTTHONISEN et al., 1976).

Para Nitrosomonas, a amônia é o substrato limitante. Já para Nitrobacter, o nitrito ocupa este posto. Visto que a velocidade de crescimento de Nitrobacteré muito maior que a de Nitrosomonas para uma extensa faixa de valores, a transformação do íon 
amônio a nitrito é considerada como a etapa limitante do processo nitrificante. Neste caso, a cinética pode ser descrita pela cinética de crescimento de Nitrosomonas (VAN HAANDEL e MARAIS, 1999). Na nitrificação, a biomassa pode ter crescimento em suspensão ou crescimento em algum meio suporte. Os processos cujo crescimento é realizado sob a forma suspensa podem ocorrer no tratamento secundário, isto é, no mesmo reator destinado à remoção de matéria orgânica, ou em um reator separado, subsequente ao tratamento secundário. A este último dá-se o nome de tratamento terciário, ou nitrificação terciária. Quando a remoção de matéria orgânica e a nitrificação ocorrem no mesmo reator, denomina-se o processo de simples estágio. Em contrapartida, quando ocorrem em reatores distintos, o processo consiste de um reator e de um decantador, a exemplo do que ocorre no processo de lodo ativado. (METCALF \& EDDY, 2013).

\subsubsection{Fatores que influenciam a nitrificação}

Diversos fatores apresentam influência direta na atividade nitrificante. Entre os principais, encontram-se $\mathrm{pH}$, temperatura, alcalinidade, concentração de oxigênio dissolvido, a relação carbono / nitrogênio $(\mathrm{C} / \mathrm{N})$ e à presença de substâncias tóxicas ou inibidoras, que exercem influência direta sobre o crescimento das bactérias, conforme já comprovado por vários pesquisadores (DOWNING et al., 1964; BARNES e BLISS, 1983 apud VON SPERLING, 2002; VAN HAANDEL e MARAIS, 1999; SEDLAK, 1991 apud METCALF e EDDY, 2013). No entanto, a relação C/N é um dos fatores críticos dos sistemas de nitrificação. Em qualquer tipo de reator, maiores taxas de nitrificação são obtidas quando há limitação da concentração de matéria carbonácea e sólidos em suspensão na entrada. Altas concentrações de matéria orgânica proporcionam condições favoráveis ao desenvolvimento de microrganismos heterotróficos que competem com os autotróficos nitrificantes pelo oxigênio e nutrientes (FIGUEROA e SILVERSTEIN, 1992). Para agravar o problema, a reação de nitrificação é muito mais lenta e mais sensível a perturbadores externos em comparação com a oxidação de matéria orgânica promovida pelos microrganismos heterotróficos (VAN HAANDEL e MARAIS, 1999). Ling e Chen (2005) investigaram a variação da taxa de nitrificação em diferentes razões $\mathrm{COD} / \mathrm{N}$ operando biofiltros distintos. Para uma concentração de substrato (nitrogênio total sob a forma de 
amônia) de 10 mg. $\mathrm{L}^{-1}$, foi verificado uma redução 60-70\% da eficiência de nitrificação quando a razão $\mathrm{COD} / \mathrm{N}$ passou de 0 a 3 . Em sistemas com biofilme, além da competição por substrato, as bactérias heterotróficas e nitrificantes competem por espaço, gerando uma estratificação na estrutura do biofilme. O crescimento mais rápido das bactérias heterotróficas faz com que esse conjunto microbiano fique localizado nas camadas mais externas do biofilme, onde a concentração de substrato e o desprendimento da biomassa são maiores, enquanto as bactérias nitrificantes ficam inseridas nas camadas mais profundas do biofilme. Desta forma, uma camada heterotrófica pode se formar sobre a população nitrificante, o que constituiu uma desvantagem a essa última, especialmente quando a concentração de oxigênio dissolvido no meio líquido é pequena. Essa limitação de OD, que é resultado do consumo e resistência à transferência de massa através da camada heterotrófica, afeta negativamente o desempenho da nitrificação. Em contrapartida, se a concentração de OD é grande o suficiente para se sobrepuser às limitações difusivas no biofilme, a camada heterotrófica pode ter um efeito positivo no consórcio microbiano nitrificante, protegendo-o do desprendimento (DE BEER, D., 1996).

Weismann (1994) ratificou o empecilho que a população heterotrófica representa ao consórcio microbiano autotrófico nitrificante. Operando-se um sistema de lodo ativado convencional, baixas eficiências de nitrificação foram atingidas, em grande parte atribuída ao fato de que a remoção de matéria orgânica e o processo de nitrificação estavam ocorrendo no mesmo reator. A cultura mista de bactérias presente no sistema consistia principalmente de heterotróficas, sendo minoritária a parcela representativa da população autotrófica. Sendo assim, o enriquecimento do sistema com bactérias autotróficas tornou-se dificultoso, tendo em vista as baixíssimas velocidades de crescimento celular apresentadas por esse grupo microbiano. Uma alternativa seria a separação da biomassa heterotrófica da autotrófica, objetivando o aumento da velocidade específica de nitrificação. O processo de nitrificação pode ocorrer em temperaturas compreendidas entre 4 e 45드, embora Nitrosomonas tenha temperatura ótima de $35^{\circ} \mathrm{C}$, e, para Nitrobacter a faixa ótima situa-se entre 35 e 42 ○C. Altas temperaturas acarretam em alto consumo de oxigênio e de alcalinidade necessários à nitrificação. Em contrapartida, baixas temperaturas diminuem a atividade nitrificante. Em temperaturas baixas $\left(<20^{\circ} \mathrm{C}\right)$, a nitratação é muito mais rápida que a nitritação, de modo que se pode considerar que a nitratação é imediata 
e a acumulação de nitrito sempre será muito pequena em sistemas sob condições estacionárias. Em contraste, em temperaturas elevadas $\left(>25^{\circ} \mathrm{C}\right)$ a nitritação é mais rápida que a nitratação, e por esta razão pode haver acumulação de nitrito quando se cria condições adequadas (VAN HAANDEL E MARAIS, 1999). A Figura 3 mostra a demanda de oxigênio na nitrificação (nitritação e nitratação) e a demanda de material orgânico na desnitrificação.

Figura 3: Variação do número de oxidação de nitrogênio nos processos de nitrificação e desnitrificação. Fonte: (VAN HAANDEL E MARAIS,1999).
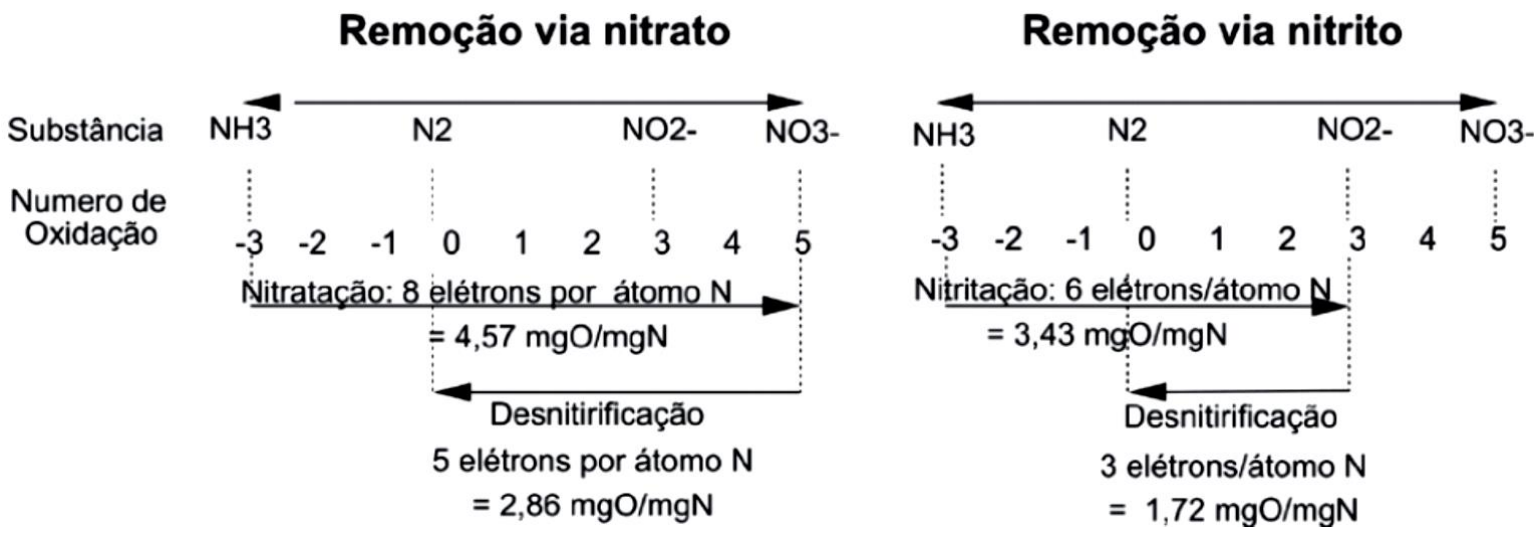

Em relação ao $\mathrm{pH}$, os microrganismos responsáveis pela nitrificação desenvolvem-se melhor em condições levemente alcalinas, podendo atuar na faixa de $\mathrm{pH}$ compreendida entre 6,5 e 9,0 (HÄNEL, 1988). Juntamente com o pH, a alcalinidade tem papel importante, tendo em vista que quantidade substancial de alcalinidade é consumida durante o processo de nitrificação $\left(7,14 \mathrm{gCaCO} / \mathrm{gN}-\mathrm{NH}_{4}+\right.$ oxidado).

Quando se trata de tratamento de efluentes, o oxigênio tem efeito significativo e é fator limitante da taxa de nitrificação, sendo a quantidade de oxigênio em uma cultura mista controlada pela matéria orgânica afluente e pela reaeração. A faixa de concentração de oxigênio dissolvido necessária para sistemas com biomassa em suspensão é de 0,5 a 2,5 $\mathrm{mgO}_{2} / \mathrm{L}$. Em contrapartida, em sistemas com biomassa fixa, onde a transferência de massa e resistência à difusão são fatores que devem ser levados em consideração, o nível de oxigênio requerido é maior (FIGUEROA e SILVERSTEIN,1992). Devido à grande constante de afinidade pelo oxigênio apresentada pelas bactérias oxidadoras de nitrito, a oxidação desse composto é mais 
sensível que a oxidação da amônia em baixas concentrações de OD, o que pode ocasionar acúmulo de nitrito em condições de limitação de oxigênio (VAN HAANDEL e MARAIS, 1999).

\subsection{Processo de desnitrificação}

A desnitrificação é a redução biológica de nitrato para nitrogênio molecular, tendo-se material orgânico como redutor. Admitindo-se uma fórmula geral estrutural $\mathrm{CxHyOz}$ para material orgânico, então as reações de redução e de oxidação podem ser escritas como:

\section{Oxidação:}

$\mathrm{CxHyOz}+(2 x-z) \mathrm{H}_{2} \mathrm{O} \rightarrow x \mathrm{CO}_{2}+(4 x+y-2 z) \mathrm{H}^{+}+(4 x+y-2 z) e$

Ou:

1/(4x+y-2z) $\mathrm{Cx} \mathrm{HyO}_{\mathrm{O}}+(2 \mathrm{x}-\mathrm{z}) /(4 \mathrm{x}+\mathrm{y}-2 \mathrm{z}) \mathrm{H}_{2} \mathrm{O} \rightarrow 1 /(4 \mathrm{x}+\mathrm{y}-2 \mathrm{z}) \mathrm{CO}_{2}+\mathrm{H}^{+}+\mathrm{e}$

Redução no caso de nitrato:

$e+6 / 5 \mathrm{H}^{+}+1 / 5 \mathrm{NO}_{3} \rightarrow 1 / 10 \mathrm{~N}_{2}+1 / 5 \mathrm{H}_{2} \mathrm{O}$

\section{Redox:}

Eq. (10)

$1 /(4 \mathrm{x}+\mathrm{y}-2 \mathrm{z}) \mathrm{CxHyO}+1 / 5 \mathrm{H}^{+}+1 / 5 \mathrm{NO}_{3}{ }_{3} \rightarrow \mathrm{x} /(4 \mathrm{x}+\mathrm{y}-2 \mathrm{z}) \mathrm{CO}_{2}+1 / 10 \mathrm{~N}_{2}+1 / 5^{*}(2 \mathrm{x}+3 \mathrm{y}-$ z) / ( $4 x+y-2 z) \mathrm{H}_{2} \mathrm{O}$

Ou:

$\mathrm{CxHyOz}+(4 x+y-2 z) / 5 \mathrm{H}^{+}+(4 x+y-2 z) / 5 \mathrm{NO}_{3}{ }_{3} \rightarrow \mathrm{x} \mathrm{CO}_{2}+1 / 5(2 \mathrm{x}+3 \mathrm{y}-2 \mathrm{z}) \mathrm{H}_{2} \mathrm{O}+1 / 10$ $(4 x+y-2 z) N_{2}$ 


\section{Redução no caso de nitrito:}

Nitrito:

$\mathrm{e}+4 / 3 \mathrm{H}^{+}+1 / 3 \mathrm{NO}_{2}^{-} \rightarrow 1 / 6 \mathrm{~N}_{2}+2 / 3 \mathrm{H}_{2} \mathrm{O}$

Redox:

Eq. (13)

$1 / 3 \mathrm{H}^{+}+1 / 3 \mathrm{NO}_{2}^{-}+1 /(4 \mathrm{x}+\mathrm{y}-2 \mathrm{z}) \mathrm{CxHyO}+(2 \mathrm{x}-\mathrm{z}) /(4 \mathrm{x}+\mathrm{y}-2 \mathrm{z}) \mathrm{H}_{2} \mathrm{O} \rightarrow \mathrm{x} /(4 \mathrm{x}+\mathrm{y}-$

2z) $\mathrm{CO}_{2}+1 / 6 \mathrm{~N}_{2}+2 / 3 \mathrm{H}_{2} \mathrm{O}$

Tanto as equações 12 e 13 como a Figura 3 mostram claramente que, em princípio, há uma grande vantagem em usar a nitritação em vez da nitratação como caminho para remoção de nitrogênio - no caso de nitritação a demanda de oxigênio é $25 \%$ menor que no caso de nitratação. Por outro lado, na desnitrificação, a demanda de material orgânico no caso de redução de nitrito é somente $3 / 5$ ou $60 \%$ da demanda no caso da redução de nitrato. Estudos realizados por Van Haandel et al., 2009 In: PROSAB - Livro 2, Capítulo 6, evidenciaram experimentalmente que a taxa de utilização de nitrito é muito menor que a taxa de utilização de nitrato - o que reduz sensivelmente a vantagem de se produzir nitrito. Outro problema é que somente é possível parar a nitrificação em nitrito quando as condições são favoráveis: temperaturas acima de $25^{\circ} \mathrm{C}$ a $30^{\circ} \mathrm{C}$. Por esta razão, em sistemas convencionais, normalmente, tem-se a nitrificação para nitrato como primeiro passo na remoção de nitrogênio. Numericamente, no caso de esgoto sanitário, a concentração do NKT no afluente geralmente é de 40 a $60 \mathrm{mgN}^{\mathrm{L} \mathrm{L}^{-1}}$, ou seja, uma fração na faixa de 0,08 a 0,12 da DQO afluente. Desta concentração total, em torno de 75 por cento é nitrogênio amoniacal e 25 por cento é nitrogênio orgânico. Nos processos de tratamento biológico dos esgotos, o nitrogênio orgânico é rapidamente, e quase quantitativamente, convertido em nitrogênio amoniacal (amonificação). Se a nitrificação ocorre, e se houver capacidade de oxigenação suficiente, então também o processo de oxidação da amônia é quase completo, deixando uma baixa concentração de nitrogênio amoniacal. Se depois da nitrificação o processo de desnitrificação se desenvolve eficientemente, o teor de nitrogênio dissolvido no efluente final será baixo, menos que $5 \mathrm{mg} / \mathrm{L}$, sendo possível observar uma eficiência 
de remoção de 90 a 95 por cento do nitrogênio no efluente, por exemplo, no caso do processo de lodos ativados. A eficiência da desnitrificação depende acentuadamente da disponibilidade de material orgânico para redução de nitrato (ou nitrito) e da temperatura (que influi na velocidade do processo). Quando a disponibilidade de material orgânico no afluente é insuficiente, existe a possibilidade de se adicionar um composto de baixo custo e degradação rápida como, por exemplo, metanol ou etanol (VAN HAANDEL et al., 2009 In: PROSAB - Livro 2, Capítulo 6).

\subsubsection{Fatores que influenciam e Condições necessárias para desnitrificação}

As condições necessárias para que o processo de desnitrificação se desenvolva no sistema de lodo ativado podem ser resumidas como se segue: presença de uma massa bacteriana facultativa; presença de nitrato e ausência de OD no licor misto; condições ambientais adequadas para o crescimento de microrganismos; presença de um doador de elétrons (redutor de nitrato).

\subsubsection{Massa bacteriana facultativa}

Uma bactéria é denominada de facultativa quando pode usar tanto OD como nitrato para oxidar o material orgânico. A maioria das bactérias que se desenvolvem no sistema de lodo ativado é facultativa. Estabeleceu-se experimentalmente que um lodo gerado sob condições aeróbias, quando sujeito a um ambiente anóxico na presença de material orgânico, demonstrará imediatamente a capacidade de usar nitrato como oxidante e continuará a desnitrificação sem variação mensurável da reatividade do lodo - enquanto a condição anóxica persiste. Conclui-se que não há necessidade do lodo se adaptar para o uso do nitrato.

\subsubsection{Presença de nitrato e ausência de OD}

A presença de $\mathrm{OD}$ em um licor misto inibe o desenvolvimento da desnitrificação. Um problema na quantificação da influência da concentração de OD sobre a desnitrificação é que se desenvolvem gradientes de concentração nos flocos. A concentração de OD no microambiente em volta de uma bactéria em um floco de lodo pode ser muito diferente daquela no seio da fase líquida (Figura 4). Efetivamente, tem 
sido observada a remoção eficiente de nitrato em reatores aerados de lodo ativado (PASVEER, 1965 e MATSCHE,1971 apud VAN HAANDEL et al., 2009 In: PROSAB Livro 2, Capítulo 6), que serão abordados na revisão sobre nitrificação e desnitrificação simultâneas (NDS) tema desse estudo.

Figura 4: Representação da variação da concentração de OD num floco em função da distância do centro para concentração subcrítica, crítica e supercrítica. Fonte: (VAN HAANDEL E MARAIS,1999).

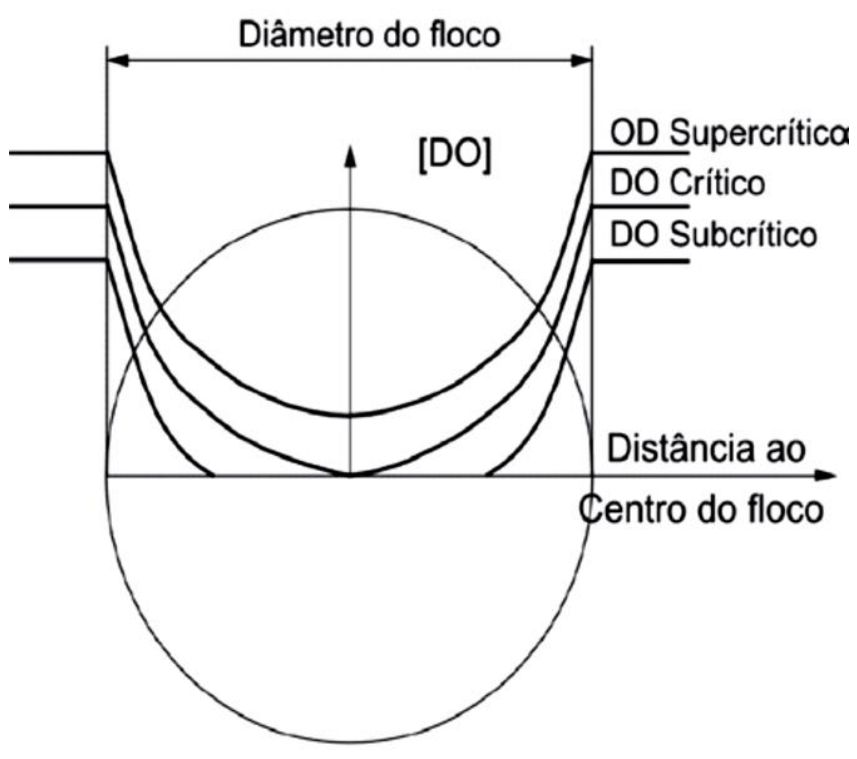

\subsubsection{Condições ambientais adequadas para os microrganismos}

Entre as condições mais importantes estão a temperatura e o pH no lodo ativado. A taxa de desnitrificação aumenta com a temperatura até um valor ótimo de $40^{\circ} \mathrm{C}$. A influência do $\mathrm{pH}$ sobre a desnitrificação tem sido observada por vários autores. A dependência da desnitrificação do $\mathrm{pH}$ é muito menos acentuada que a da nitrificação, de modo que, quando há condições de pH favoráveis para nitrificação, a desnitrificação também se desenvolverá bem. Entre as condições ambientais adequadas tem-se, ainda, a necessidade de não se ter limitação por substâncias tóxicas. Não há muita informação sobre influência de materiais tóxicos para desnitrificação além da inibição já mencionada de OD e íons de hidrogênio $(\mathrm{pH})$. Em geral, observa-se que as bactérias nitrificantes são mais sensíveis à presença de materiais tóxicos do que as bactérias atuantes na desnitrificação. Logo, quando a nitrificação se desenvolve, a desnitrificação também é possível (VAN HAANDEL et al., 2009. In: PROSAB - Livro 2, Capítulo 6). 
A presença de um doador de elétrons é essencial para redução de nitrato. O doador de elétrons na desnitrificação é o material orgânico biodegradável. De acordo com a natureza do material orgânico, podem-se definir diferentes classes de sistema de desnitrificação; dois que serão mais propriamente considerados. Os primeiros são os sistemas com uma fonte externa de material orgânico. Nestes sistemas, o material orgânico é adicionado após a nitrificação. Entre os materiais usados na prática estão o metanol, o etanol, a acetona e o ácido acético. Os segundos são os sistemas que possuem uma fonte interna de material orgânico. Neste caso, o material orgânico do afluente é usado para redução de nitrato. Como material orgânico pode-se utilizar aquele do afluente ou então a massa bacteriana (respiração endógena) (VAN HAANDEL et al., 2009. In: PROSAB - Livro 2, Capítulo 6).

\subsubsection{Estequiometria das reações do material nitrogenado}

\subsubsection{Consumo de oxigênio}

Quanto ao consumo de oxigênio para o material nitrogenado, interessam somente os processos de nitrificação e desnitrificação. Ainda, com base na Figura 3 se observa esquematicamente a transferência de elétrons nos processos de nitrificação e desnitrificação. Observa-se que, na nitrificação, o número de oxidação do nitrogênio na amônia (-3) aumenta para (+5) no nitrato através da transferência de 8 elétrons por átomo de nitrogênio, que são aceitos pelo oxigênio, sendo preciso quatro átomos (duas moléculas) de oxigênio para isso (no oxigênio o número de oxidação muda de 0 para -2 na reação). Portanto, na nitrificação de 1 mol de $\mathrm{N}$ amoniacal, o consumo de oxigênio é de 64/14 = 4,57 mgO.mg N${ }^{-1}$ (VAN HAANDEL E MARAIS,1999). No processo de desnitrificação, o oxidante nitrato (número de oxidação $=+5$ ) é reduzido para nitrogênio molecular (número de oxidação $=0$ ), havendo, portanto, transferência de 5 elétrons por átomo $\mathrm{N}$. Nota-se que, dos 8 elétrons liberados pelo nitrogênio amoniacal na sua oxidação para nitrato, somente 5 são recuperados quando o nitrato é reduzido para nitrogênio molecular. Desse modo, em termos de equivalentes oxidimétricos, o nitrato na desnitrificação tem uma capacidade de oxidação igual a uma fração 5/8 de oxigênio necessário na nitrificação. Em outras palavras, uma fração de 5/8 = 0,625 do consumo de oxigênio na nitrificação $\left(4,57 \mathrm{mgO}^{\mathrm{mg} \mathrm{N}} \mathrm{N}^{-1}\right)$ pode ser recuperada como "oxigênio equivalente" no processo de desnitrificação. Isto é: 
$0,625^{\star} 4,57=2,86 \mathrm{mg} \mathrm{O}^{\mathrm{mg} \mathrm{N}} \mathrm{m}^{-1}$. Conclui-se que, para a remoção de nitrogênio, há um

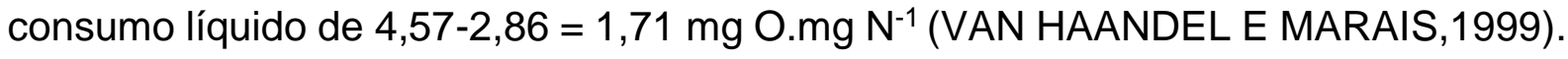

\subsection{Variação da alcalinidade no processo de amonificação, nitrificação e desnitrificação}

O efeito da amonificação, nitrificação e desnitrificação sobre a alcalinidade pode ser deduzido por simples relações estequiométricas, usando-se as equações de reação dos três processos (equações 14a, 14b, 14c (VAN HAANDEL et al., 2009 In: PROSAB - Livro 2, Capítulo 6). Observa-se que, nas três reações, há envolvimento de íons de hidrogênio: na amonificação há consumo de $1 \mathrm{~mol}$ de $\mathrm{H}^{+}$por mol de amônia produzido; na nitrificação há produção de 2 moles de $\mathrm{H}^{+}$por mol de nitrato formado, e na desnitrificação há consumo de $1 \mathrm{~mol}$ de $\mathrm{H}^{+}$por mol de nitrato reduzido. Sabendo-se que a produção de $1 \mathrm{~mol} \mathrm{de} \mathrm{H}^{+}$(acidez mineral) equivale ao consumo de $1 \mathrm{~mol}$ de alcalinidade (ou $50 \mathrm{~g} \mathrm{CaCO}_{3}$ ), tem-se, nos três processos as situações que serão consideradas a seguir: No processo de amonificação, há uma produção de alcalinidade de $50 \mathrm{~g}$ por mol amônia $(14 \mathrm{~g} \mathrm{~N}$ ) amonificado. No processo de nitrificação, há um consumo de alcalinidade de $2 \times 50=100 \mathrm{~g} \mathrm{CaCO}_{3}$ por mol $\mathrm{N}(14 \mathrm{~g})$. Finalmente, no processo de desnitrificação, produz-se $50 \mathrm{~g} \mathrm{CaCO}_{3}$ por mol $\mathrm{N}$. As variações da alcalinidade podem ser expressas como:

Eq. (14a)

$(\Delta \mathrm{alc} / \Delta \mathrm{N})_{\mathrm{am}}=50 / 14=3,57 \mathrm{mg} \mathrm{CaCO}_{3} \cdot \mathrm{mgN}^{-1}$

$(\Delta \mathrm{alc} / \Delta \mathrm{N})_{\mathrm{n}}=-100 / 14=-7,14 \mathrm{mg} \mathrm{CaCO} \cdot \mathrm{mgN}^{-1}$

$(\Delta \mathrm{alc} / \Delta \mathrm{N})_{\mathrm{d}}=50 / 14=3,57 \mathrm{mg} \mathrm{CaCO}_{3} \cdot \mathrm{mgN}^{-1}$

Onde:

$(\Delta$ alc/ $\Delta \mathrm{N})$ : variação da alcalinidade por $\mathrm{mg} \mathrm{N}$.

am: amonificação

n: nitrificação

d: desnitrificação

No caso de esgoto municipal, o efeito da amonificação sobre a alcalinidade é geralmente pequeno, como mostra a seguinte análise. A concentração de nitrogênio 
amonificado no sistema de lodo ativado é dada pela diferença entre o nitrogênio orgânico afluente e a soma de nitrogênio orgânico no efluente e no lodo de excesso, ou seja:

$\mathrm{Nam}=\mathrm{N}_{\mathrm{oa}}-\left(\mathrm{N}_{\mathrm{oe}}+\mathrm{N}_{\mathrm{l}}\right)$

Onde:

$\Delta \mathrm{Nam}$ : concentração de nitrogênio amonificado no sistema de lodo ativado (mgN.L-1)

Noa: concentração de nitrogênio orgânico afluente $\left(\mathrm{mgN} . \mathrm{L}^{-1}\right)$

Noe: concentração de nitrogênio orgânico efluente (mgN.L-1)

Nı: concentração de nitrogênio orgânico no lodo de excesso $\left(\mathrm{mgN} . \mathrm{L}^{-1}\right)$

Normalmente para esgoto sanitário, a concentração do nitrogênio orgânico no efluente é muito pequena (em torno de 1 a 2 mgN.L-1), enquanto os valores das concentrações Noa e Nıão aproximadamente iguais a 25 por cento do NTK do afluente. Desse modo, a variação da concentração de nitrogênio orgânico é muito pequena e, consequentemente, a variação da alcalinidade devido à amonificação também será pequena. A variação da alcalinidade devido à amonificação é dada por:

$\Delta$ alcam $=3,57 \Delta \mathrm{Nam}_{\mathrm{a}}=3,57\left(\mathrm{~N}_{\mathrm{oa}}-\mathrm{N}_{\mathrm{oe}}-\mathrm{N}_{\mathrm{l}}\right)$

Onde o valor de $\Delta$ alcam pode ser positivo ou negativo.

A variação da alcalinidade em um sistema de tratamento de esgoto, devido à nitrificação, é calculada a partir da concentração de amônia nitrificada. Esta concentração é igual à diferença entre a concentração do NKT afluente (Nka) e a soma das concentrações do NKT efluente $\left(N_{k e}\right)$ e aquela necessária para a produção de lodo $\left(\mathrm{N}_{\mathrm{I}}\right)$.

$N_{c}=N_{k a}-N_{k e}-N_{l}$

Eq. (17)

Onde:

$\mathrm{N}_{\mathrm{c}}$ : concentração de amônia afluente nitrificada no sistema (mgN.L-1) 
O efeito da nitrificação sobre a alcalinidade pode ser expressado como:

$\Delta$ alc $c_{n}=-7,14 N_{c}=-7,14\left(N_{k a}-N_{k e}-N_{1}\right)$

Devido a desnitrificação, a variação da alcalinidade depende da concentração do nitrato removido do sistema. Essa concentração é dada por:

$\Delta N_{d}=N_{n a}+N_{c}-N_{n e}$

Portanto, a variação da alcalinidade ocasionada pela desnitrificação pode ser expressa como:

Eq. (20)

$\Delta$ alcd $=3,57 \Delta N_{d}=3,57\left(N_{n a}+N_{k a}-N_{k e}-N_{l}-N_{n e}\right)$

A variação total da alcalinidade do sistema de lodo ativado devido às reações de nitrogênio será igual à soma dos efeitos da amonificação, nitrificação e desnitrificação.

Eq. (21)

$\Delta \mathrm{alC}_{\mathrm{t}}=\Delta \mathrm{alCam}_{\mathrm{C}}+\Delta \mathrm{alC}_{\mathrm{n}}+\Delta \mathrm{al} \mathrm{C}_{\mathrm{d}}=3,57\left(\mathrm{Noa}_{\mathrm{oa}}-\mathrm{N}_{\mathrm{oe}}-\mathrm{N}_{\mathrm{l}}\right)-7,14\left(\mathrm{~N}_{\mathrm{ka}}-\mathrm{N}_{\mathrm{ke}}-\mathrm{N}_{\mathrm{l}}\right)+3,57\left(\mathrm{~N}_{\mathrm{na}}+\mathrm{N}_{\mathrm{ka}}-\mathrm{N}_{\mathrm{ke}}-\mathrm{N}_{\mathrm{l}}-\right.$ $\mathrm{Nne})$

Lembrando que a concentração do NTK é a soma da concentração de nitrogênio orgânico (No) e amoniacal (Na), a Equação 21 se simplifica para:

Eq. (22)

$\Delta \mathrm{alc}_{\mathrm{t}}=-3,57\left(\mathrm{~N}_{\mathrm{aa}}-\mathrm{N}_{\mathrm{na}}-\mathrm{N}_{\mathrm{ae}}+\mathrm{N}_{\mathrm{ne}}\right)=3,57\left(\Delta \mathrm{N}_{\mathrm{a}}-\Delta \mathrm{N}_{\mathrm{n}}\right)$

Na prática, a alcalinidade natural das águas residuárias poderá ter um valor inferior aquele necessário para manter um $\mathrm{pH}$ estável no reator onde ocorre a nitrificação. Isto é particularmente provável quando o sistema é inteiramente aeróbio, ou seja, quando 
a nitrificação se desenvolve, sem que a desnitrificação ocorra. Nesse caso, torna-se necessário aumentar a alcalinidade da água residuárias - o que geralmente é feito através de adição de cal. Sem adição de alcalinidade, o comportamento do sistema de lodo ativado será instável: haverá períodos de nitrificação eficiente e, consequentemente, redução da alcalinidade e do $\mathrm{pH}$ até que ele atinja um valor que não permite o desenvolvimento da nitrificação. Quando a nitrificação é inibida, automaticamente, a alcalinidade e o pH aumentarão pela introdução do afluente até que se criem novamente condições favoráveis para a nitrificação. Inicia-se, então, um novo ciclo. Se a desnitrificação é incluída no sistema de tratamento, então a diminuição da alcalinidade será menor e muitas vezes não haverá necessidade de adição de cal. Isto ocorre porque, no processo de desnitrificação, há produção de alcalinidade (VAN HAANDEL et al., 2009 In: PROSAB - Livro 2, Capítulo 6).

$\Delta \mathrm{alc}_{\mathrm{t}}=3,57\left(\mathrm{~N}_{\mathrm{aa}}-\mathrm{N}_{\mathrm{na}}-\mathrm{N}_{\mathrm{ae}}+\mathrm{N}_{\mathrm{ne}}\right)=3,57\left(\Delta \mathrm{N}_{\mathrm{a}}-\Delta \mathrm{N}_{\mathrm{n}}\right)$

Onde:

$\Delta \mathrm{Na}$ : variação da concentração de amônia no sistema

$\Delta \mathrm{N}_{\mathrm{n}}$ : variação da concentração de nitrato no sistema

Na equação 23, os parâmetros à direita podem ser determinados experimentalmente usando-se testes padronizados. Logo, é possível calcular teoricamente qual a variação da alcalinidade causada pelo efeito estequiométrico combinado de amonificação, nitrificação e desnitrificação. Este valor é, então, posteriormente comparado com a variação observada da alcalinidade. Na Figura 5 se observam resultados de variação teórica e experimental da alcalinidade, mostrando que há uma boa correlação entre teoria e experimento. 
Figura 5: Variação teórica versus variação experimental da alcalinidade para diferentes sistemas de lodo ativado. Fonte: (VAN HAANDEL E MARAIS,1999).

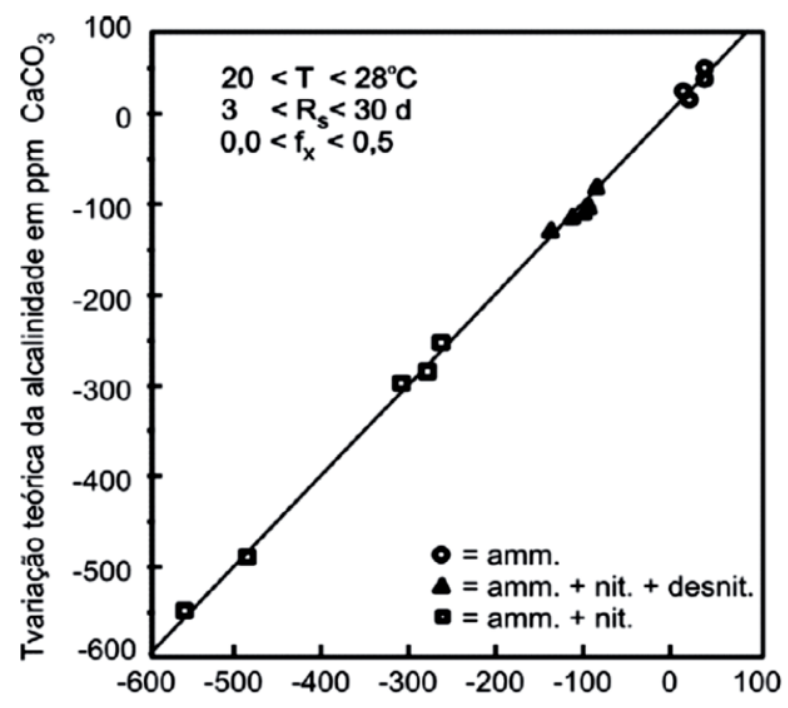

\subsection{Possibilidades de impacto do ciclo do nitrogênio na atmosfera}

Os óxidos de nitrogênio (NOx) podem ser caracterizados pelo óxido nítrico (NO), dióxido de nitrogênio $\left(\mathrm{NO}_{2}\right)$, trióxido de nitrogênio $\left(\mathrm{N}_{2} \mathrm{O}_{3}\right)$, pentóxido de nitrogênio $\left(\mathrm{N}_{2} \mathrm{O}_{5}\right)$ e óxido nitroso $\left(\mathrm{N}_{2} \mathrm{O}\right)$. Alguns óxidos de nitrogênio, tais como $\mathrm{NO}$ e $\mathrm{N}_{2} \mathrm{O}$, são produzidos por processos naturais como os relâmpagos, erupções vulcânicas e ações bacteriológicas nos solos e oceanos (LOUREIRO, 2005). O N $\mathrm{N}_{2} \mathrm{O}$, na natureza, é produzido por processos microbiológicos de nitrificação e desnitrificação em sistemas continentais e marinhos (solos, água e sedimentos) (GUIMARÃES e MELLO, 2008). Em inúmeras ações humanas ocorrem emissões de gases que podem acarretar danos ambientais locais e globais. Além dos processos naturais, as atividades humanas vêm acelerando ao longo do tempo os processos de emissão dos NOx, influenciando fortemente os ciclos biogeoquímicos. A fixação de $\mathrm{N}_{2}$ atribuída às atividades antrópicas se dá principalmente a partir de três processos, conforme descrito por Galloway (2004):

- o desenvolvimento do processo de Haber-Bosch;

- pelo cultivo de plantas fixadoras de $\mathrm{N}_{2}$ como soja e arroz;

- e a queima de combustíveis fósseis. 
O processo de Haber-Bosch produz amônia a partir da reação do nitrogênio gasoso à alta pressão (200 atm) e altas temperaturas $\left(450^{\circ} \mathrm{C}\right)$, acelerando o processo de incorporação de formas reativas de nitrogênio na atmosfera. Os alemães, com o objetivo de reduzir a importação de nitrato para munição do Chile, utilizavam para tal o amônio produzido como resultado do processo (OMETTO e MARTINELLI, 2008). Tal processo foi fundamental para que se desse início à produção de fertilizantes nitrogenados para aumento da produção de alimentos. Como a vegetação consegue reter apenas parte do material incorporado ao solo, o restante é perdido para o ambiente por processos de erosão, ou através da emissão para a atmosfera (FELIX e CARDOSO, 2004). A emissão de óxidos nitrosos na atmosfera também é consequência do aumento do cultivo de plantas fixadoras de nitrogênio, como extensos plantios de soja e arroz, de forma indiscriminada. A queima de combustíveis fósseis para produção de energia tem como principal consequência a geração de gases residuais incluindo os óxidos de nitrogênio $\mathrm{NOx}$ ( $\mathrm{NO}$ e $\mathrm{NO}_{2}$ ), mas principalmente NO. O nitrogênio que foi fixado durante anos pela planta, quando é queimado junta-se à oferta global de $\mathrm{N}$ na atmosfera na forma de NOx (GALLOWAY, et al., 2004). Neste contexto podem ser citados ainda o desenvolvimento de pastos para criação de gado, e a emissão em disposição e tratamentos de esgotos (PENNER, J. E., 1999). O $\mathrm{N}_{2} \mathrm{O}$ é o segundo composto de nitrogênio (N) mais abundante na atmosfera e origina-se, processos biológicos de nitrificação e desnitrificação, de fontes naturais (80\%) e antrópicas (20\%) (OLIVIER et al., 1998). Exerce importante papel no controle do ozônio $\left(\mathrm{O}_{3}\right)$ estratosférico, pois o $\mathrm{N}_{2} \mathrm{O}$ gerado é retirado da atmosfera por fotólise a partir da luz solar na estratosfera. Esta reação é a principal fonte de NO na estratosfera, que desempenha um papel fundamental no controle da quantidade e da distribuição do ozônio estratosférico, por reagir com o mesmo (COFALA, J., 1998). Além da ação na camada de ozônio, é responsável por $6 \%$ do efeito estufa, gerando cerca de 300 vezes mais calor que o dióxido de carbono (CO2) (HANSEN et al., 1997). Tendo em vista as informações citadas acima, fica claro que o aumento das emissões de dióxido de nitrogênio na atmosfera, resultante dos processos citados e do aumento da população mundial, é um fator determinante e de fundamental importância para os efeitos ambientais globais. Sendo assim, é importante que, além dos estudos já realizados sobre o mesmo, este óxido nitroso seja alvo da atenção de novas pesquisas a fim de compreender a melhor forma de prevenir danos ambientais causados por ele. 


\subsubsection{O óxido nitroso nas águas residuárias e a emissão de $\mathrm{N}_{2} \mathrm{O}$ em processos de lodos ativados}

Nas águas residuárias são encontrados materiais nitrogenados como nitrogênio amoniacal gasoso $\left(\mathrm{NH}_{3}\right)$, nitrogênio amoniacal salino $\left(\mathrm{NH}_{4}\right)$ e nitrogênio orgânico (ureia, aminoácidos e outras substâncias orgânicas com o grupamento amino), ocasionalmente ocorrem traços de formas oxidadas do nitrogênio (nitrito e nitrato). A soma da concentração de nitrogênio orgânico e o amoniacal é chamada de nitrogênio total de Kjeldahl (NKT) (VAN HAANDEL E MARAIS,1999). A resolução CONAMA $357 / 2005$, que dispõe sobre a classificação dos corpos de água e diretrizes ambientais para seu enquadramento e estabelece padrões de lançamento de efluentes, caracteriza o valor máximo permitido para concentração de $\mathrm{N}$ amoniacal como até 20 $\mathrm{mg} / \mathrm{L}$, não estabelece parâmetros para outros componentes nitrogenados. Ainda, ao classificar os corpos d'água, a mesma resolução apresenta padrões para as águas doces de classe 1, onde tais efluentes são lançados, como $\mathrm{DBO}_{5,20} \leq 3 \mathrm{mg} \cdot \mathrm{L}^{-1} \mathrm{O}_{2}$, $\mathrm{OD}$ $\geq 6 \mathrm{mg} \cdot \mathrm{L}^{-1} \mathrm{O}_{2}$, pH de 6,0 a 9,0, nitrato $\leq 10,0 \mathrm{mg} \cdot \mathrm{L}^{-1} \mathrm{~N}$, nitrito $\leq 1,0 \mathrm{mg} \cdot \mathrm{L}^{-1} \mathrm{~N}$ e nitrogênio amoniacal total de 0,5 a $3,7 \mathrm{mg} / \mathrm{L} \mathrm{N}$ variando conforme $\circ \mathrm{pH}$ de $7,5 \geq \mathrm{pH}>8,5$ (PICOLLI, 2010). O nitrogênio amoniacal encontrado nos corpos hídricos sofre influência dos fatores físicos e químicos no meio, como $\mathrm{pH}$, temperatura, salinidade, dentre outros, que podem proporcionar a produção de diferentes compostos de nitrogênio podendo estes serem tóxicos aos corpos hídricos. A amônia em altas concentrações atravessa, por difusão, as membranas respiratórias dos peixes, causando danos ao epitélio branquial dificultando a obtenção do $\mathrm{O}_{2}$, desestabilizando o sistema osmorregulador causando a morte (ARANA, 1997). O íon nitrato, quando encontrado na água, é um indicador de eutrofização dos corpos hídricos, evidenciando a existência de atividade bacteriana e de alterações orgânicas no manancial. Embora seja considerado como um composto de baixa toxicidade, caso ingerido em quantidades excessivas o nitrato pode ser reduzido a nitrito e este, em altas concentrações, oxida o átomo de ferro da molécula da hemoglobina do sangue, convertendo-a em meta-hemoglobina, molécula incapaz de transportar oxigênio para os tecidos, estabelecendo-se um quadro de hipóxia e cianose (ARANA, 1997). Sendo assim, os sistemas de tratamento de águas residuárias devem não somente visar à redução do nitrogênio amoniacal, mas também de todas as formas nitrogenadas e 
reduzir a emissão de $\mathrm{N}_{2} \mathrm{O}$. A emissão de $\mathrm{N}_{2} \mathrm{O}$ em estações de tratamento de esgotos está associada com a degradação dos componentes nitrogenados como ureia, amônia, nitrato e proteínas e podem ocorrer nas diversas unidades de uma Estação de Tratamento de Esgoto (ETE), como produto em processos de nitrificação ou desnitrificação (PICOLLI, 2010). Como há o ciclo biológico do nitrogênio na natureza, a remoção biológica do nitrogênio em efluentes também pode ocorrer através da transformação do nitrogênio orgânico em nitrogênio amoniacal, para posteriormente se oxidar a nitrito e nitrato e estes serem desnitrificados a nitrogênio molecular $\left(\mathrm{N}_{2}\right)$, reduzindo desta forma os níveis de $\mathrm{N}$ no esgoto tratado (VAN HAANDEL e MARAIS, 1999). Como visto anteriormente, o O $\mathrm{O}_{2}$ é um fator limitante e essencial no processo de nitrificação. O oxigênio dissolvido no reator em sistemas de lodo ativados atua como pré-requisito sendo que não é a continuidade, mas a eficácia da aeração que mantém a concentração de oxigênio dissolvido de maneira que ocorra a nitrificação. Esta concentração de oxigênio deve ser acima da concentração crítica $\left(\approx 0,2 \mathrm{mg} \cdot \mathrm{L}^{-1}\right)$ (BARNES \& BLISS apud VON SPERLING, 2002), e é a taxa de aeração que possibilita isso (PICOLLI, 2010). Entre as premissas de um projeto de ETE devem estar não somente a redução dos custos operacionais da mesma, mas também a minimização de impactos nos corpos hídricos e a redução de gases do efeito estufa. Isto é, ter como objetivo uma metodologia de tratamento que seja eficiente na remoção de matéria orgânica, mas com monitoramento e controle dos gases emitidos durante 0 processo.

\subsection{Generalidades sobre o processo de lodos ativados}

O processo de lodos ativados são sistemas biológicos amplamente utilizados para o tratamento de despejos domésticos e industriais, em nível mundial, devido, principalmente à qualidade do efluente e os baixos requisitos por área, além da possibilidade de se variar alguns processos. No entanto, o sistema de lodo ativado inclui um índice de mecanização superior ao de outros sistemas de tratamento, implicando em uma operação mais sofisticada e em maiores consumos de energia elétrica (VON SPERLING, 2002). A Figura 6 mostra as unidades que são partes integrantes da etapa biológica do sistema de lodos ativados: 
Figura 6: Esquema das unidades da etapa biológica do sistema de lodo ativado

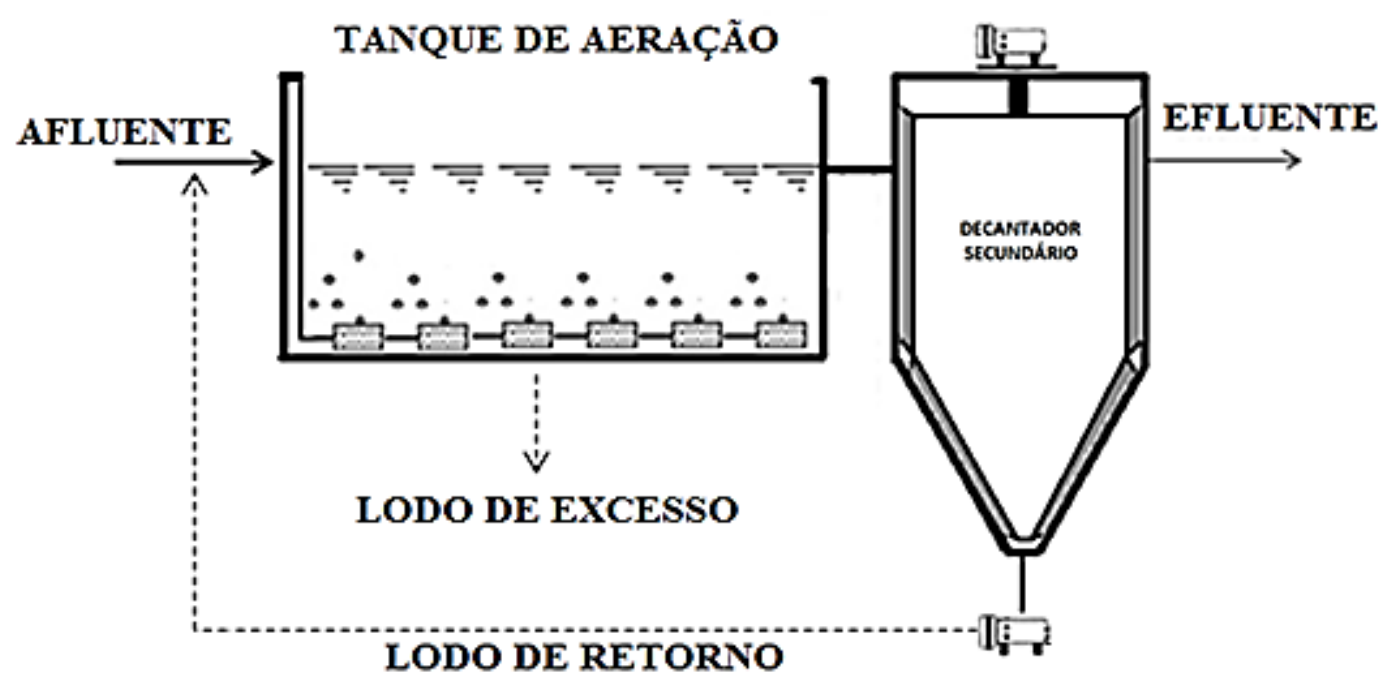

No tanque de aeração (reator) ocorrem as reações bioquímicas de remoção de matéria orgânica e, em determinadas condições, da matéria nitrogenada. A matéria orgânica é em parte convertida em biomassa bacteriana (lodo) e em parte mineralizada para $\mathrm{CO}_{2}$ e $\mathrm{H}_{2} \mathrm{O}$. Devido às boas características de sedimentabilidade do lodo, a biomassa bacteriana pode ser separada do efluente tratado por simples sedimentação no decantador secundário, permitindo que o efluente final saia clarificado (METCALF \& EDDY, 2013). Os sólidos sedimentados no fundo do decantador secundário são recirculados para o tanque de aeração, aumentando a concentração de biomassa ativa do mesmo, o que é responsável pela elevada eficiência do sistema. Em um sistema de lodo ativado convencional os sólidos são recirculados do fundo da unidade de decantação, por meio de bombeamento, para a unidade de aeração. No sistema de lodo ativado, o tempo de detenção do líquido é bem baixo, da ordem de horas, implicando em que o volume do tanque de aeração seja bem reduzido. No entanto, devido à recirculação dos sólidos, estes permanecem no sistema por um tempo superior ao do líquido. O tempo de retenção dos sólidos é denominado idade do lodo, ou seja, a idade de lodo representa o tempo médio que uma partícula de lodo permanece no sistema, e pode ser determinada pela razão: massa de lodo no reator pela massa de lodo descarregada diariamente (grosseiramente dividindo-se a quantidade de lodo (seco) contida no tanque de aeração pela quantidade diária de lodo (seco) retirada do sistema como lodo em 
excesso). É o parâmetro fundamental para o dimensionamento e operação de sistemas de lodo ativado (VAN HAANDEL E MARAIS,1999). Ainda, no tanque de aeração, devido à entrada contínua de alimento, na forma de DBO dos esgotos, os microrganismos crescem e se reproduzem continuamente. Para manter o sistema em equilíbrio, é necessário que se retire aproximadamente a mesma quantidade de biomassa que é aumentada por reprodução. Este é, portanto, o lodo biológico excedente, que pode ser extraído diretamente do tanque de aeração ou da linha de recirculação.

\subsubsection{Processos biológicos para remoção de nitrogênio}

Estudos mais recentes têm mostrado que a remoção biológica de nitrogênio pode acontecer de outras formas além da via comum: nitrificação e desnitrificação completas. Os novos processos consistem em rotas alternativas de remoção biológica de nitrogênio em águas residuárias. Abaixo é apresentada uma breve introdução aos diferentes tipos de tratamentos de remoção de nitrogênio tradicionais e mais recentes.

\subsubsection{Sistema de Lodos Ativados com pré-nitrificação}

Tendo em vista a necessidade não apenas da nitrificação do esgoto, como também a redução biológica do nitrato. Entende-se que, nos dias atuais, as alternativas de prédesnitrificação e de pós-desnitrificação, processos que podem ser associados aos sistemas de lodos ativados, são satisfatoriamente conhecidos. O reator possui uma zona anóxica seguida pela zona aeróbia. A nitrificação ocorre na zona aeróbia, conduzindo a formação de nitratos. Os nitratos são direcionados a zona anóxica por meio da recirculação interna, como se observa na Figura 7. Embora possa ser futuramente implantado nas ETEs em operação, o arranjo com pré-desnitrificação tem por principal aspecto desfavorável a necessidade de grandes vazões de recirculação de lodo da zona aerada para a zona anóxica (100 a 400\%) da vazão afluente, dependendo da concentração de nitrato a ser obtida no efluente final, acarretando elevação significativa dos custos operacionais em função do consumo de energia elétrica por estas elevatórias adicionais (METCALF \& EDDY, 2013). 
Figura 7: Representação esquemática de um sistema de lodo ativado com prédesnitrificação.

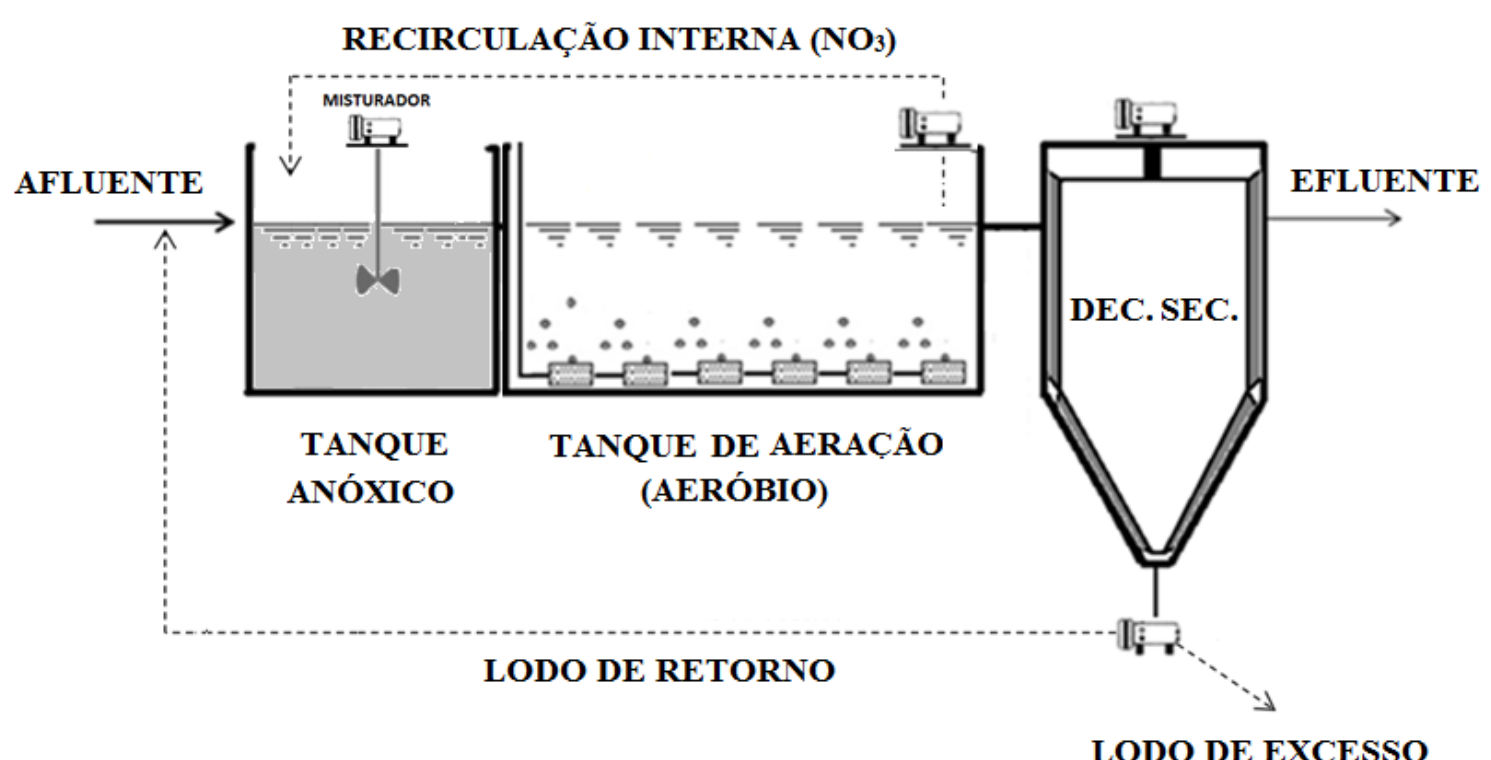

\subsubsection{Sistema de Lodos Ativados com pós-nitrificação}

O sistema é composto por um reator com uma zona aeróbia seguida por uma zona anóxica e, opcionalmente, uma zona aeróbia final. A remoção de carbono e a produção de nitratos ocorrem na zona aeróbia. Os nitratos formados entram na zona anóxica, onde são reduzidos a nitrogênio gasoso. Desta forma, não há necessidade de recirculações internas como no sistema de pré-desnitrificação. A desvantagem é que a desnitrificação ocorre em condições endógenas, já que a maior parte do carbono orgânico é removido na zona aeróbia. Em decorrência a taxa de desnitrificação é mais lenta $\left(0,015\right.$ a $\left.0,045 \mathrm{mgNO}_{3}-\mathrm{N} . \mathrm{mgSSV}^{-\mathrm{d}^{-1}}\right)$ (VON SPERLING, 2002) conforme se observa na Tabela 1 os valores típicos das taxas de desnitrificação por miligrama de sólidos ativos por dia, obtidas em sistemas de lodo ativado com pré-desnitrificação e pós-desnitrificação tendo como substrato esgoto bruto. Uma possibilidade para se aumentar a taxa de desnitrificação na zona anóxica é adição artificial de carbono orgânico ou de se direcionar parte do esgoto bruto diretamente à zona anóxica. No entanto, o uso do esgoto pode acarretar problemas na zona anóxica, devido à introdução de amônia não nitrificada, deteriorando a qualidade do efluente final. Em 
relação à adição artificial de carbono orgânico, há uma elevação significativa dos custos operacionais no sistema. A zona aerada final (opcional) é operada com baixo TDH (em torno de 30 minutos) (Figura 8). As principais finalidades são o desprendimento das bolhas de nitrogênio gasoso e a adição de oxigênio dissolvido antes da sedimentação (METCALF \& EDDY, 2013).

Tabela 1: Taxa de desnitrificação por miligrama de sólidos suspensos voláteis por dia, em sistemas de lodo ativado com pré-desnitrificação e pós-desnitrificação.

\begin{tabular}{|c|c|c|}
\hline \multicolumn{3}{|c|}{ Taxa de desnitrificação específica } \\
\hline Tipo & Posição da zona anóxica & $\begin{array}{l}\text { Taxa de desnitrificação } \\
\left(\mathrm{mgNO}_{3}^{-}-\mathrm{N}_{\mathrm{mgSSV}} \mathrm{d}^{-1}\right)\end{array}$ \\
\hline Esgoto bruto & $\begin{array}{l}\text { Zona anóxica a montante da zona } \\
\text { aerada (Pré-D) }\end{array}$ & $0,03-0,11$ \\
\hline $\begin{array}{l}\text { Metabolismo } \\
\text { endógeno }\end{array}$ & $\begin{array}{l}\text { Zona anóxica a jusante da zona } \\
\text { aerada (Pós-D) }\end{array}$ & $0,015-0,045$ \\
\hline
\end{tabular}

Fonte: (METCALF \& EDDY, 2013).

Figura 8: Representação esquemática de um sistema de lodo ativado com pósdesnitrificação.

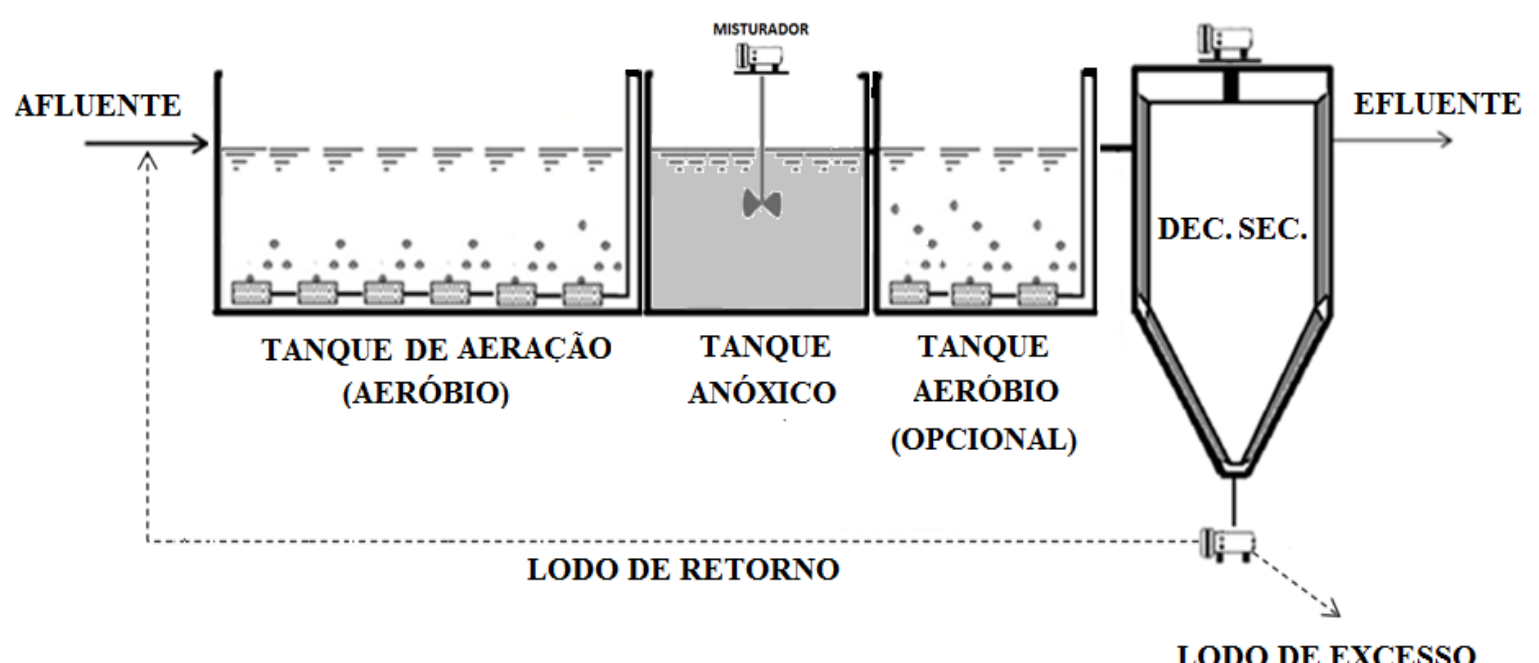

\subsubsection{Sistema de Lodos Ativados BARDENPHO}

O processo Bardenpho de 3 estágios corresponde a uma combinação dos dois arranjos (Pré-desnitrificação e Pós-desnitrificação), além da zona de re-aeração final (opcional), como se observa na Figura 9. A eficiência de remoção de nitrogênio é bastante elevada, da ordem de $90 \%$ ou mais, já que os nitratos não removidos na 
primeira zona anóxica podem ser removidos na segunda zona anóxica. No entanto o TRS na zona aerada deve ser suficiente para ocorrência da nitrificação.

A desvantagem desse sistema é a necessidade de reatores com volume total maior. Existem variantes desse sistema como o Bardenpho modificado de 3 estágios com o primeiro reator anaeróbio seguido de um anóxico e um aeróbio, e o Bardenpho modificado de 5 estágios (anaeróbio-anóxico-aeróbio-anóxico-aeróbio) que podem agregar a remoção biológica de fósforo na zona anaeróbia do sistema. No entanto, há uma tendência de formação de lodo filamentoso e a desnitrificação pode ser incompleta devido à falta de matéria orgânica (VON SPERLING, 2002 e VAN HAANDEL E MARAIS,1999).

Figura 9: Representação esquemática de um sistema de lodo ativado pelo processo Bardenpho de 3 estágios.

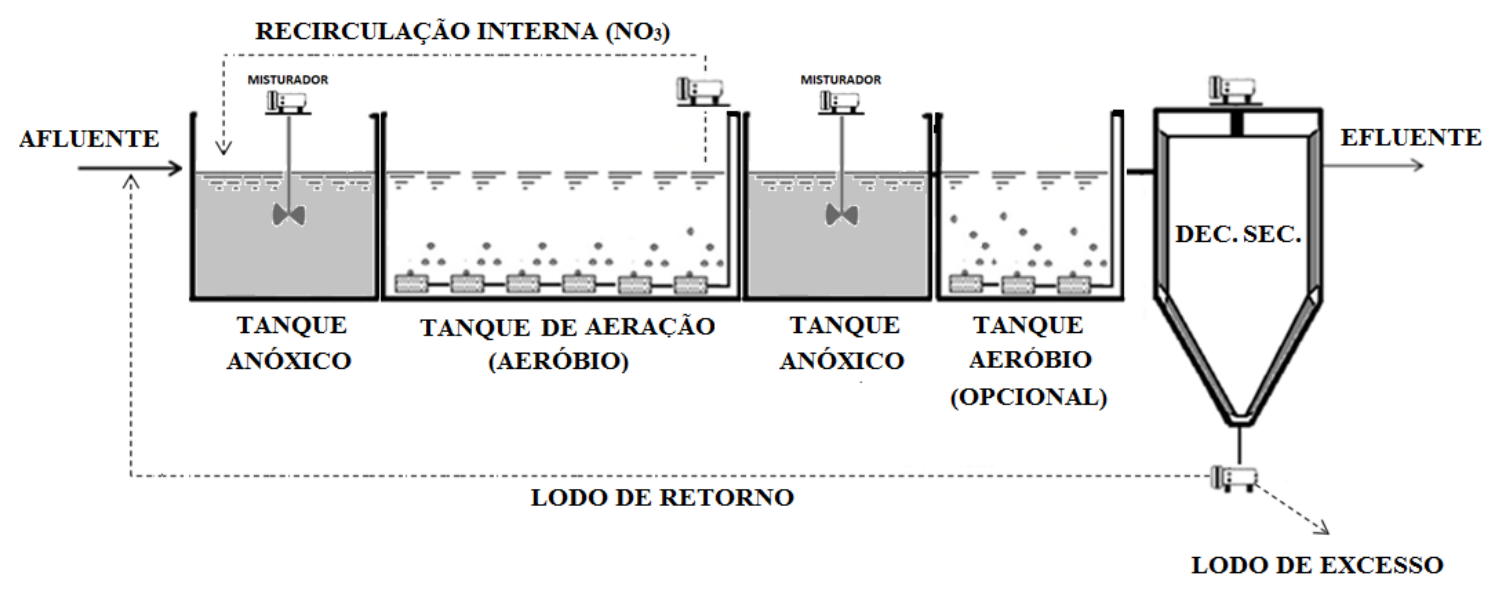

\subsubsection{Sistema de Lodos Ativados UCT (University of Cape Town)}

O sistema UCT que é um sistema de lodo ativado composto de 4 reatores sendo o primeiro anaeróbio, o segundo e o quarto anóxicos e o terceiro aeróbio, podendo ou não apresentar um quinto reator, sendo este aeróbio. Após a série de reatores há um decantador secundário. O sistema UCT, proposto por Raninowitz e Marais (1980) apud (VAN HAANDEL E MARAIS,1999), foi desenvolvido para que, simultaneamente, houvesse a remoção dos macronutrientes nitrogênio e fósforo. Para a remoção de 
fósforo nesse sistema, assim como para o sistema Bardenpho há necessidade da presença de uma zona anaeróbia e de material rapidamente biodegradável.

No sistema UCT (Figura 10) se evita a introdução de nitrato na zona anaeróbia (como ocorre no sistema Bardenpho modificado com 3 e/ou 5 reatores), introduzindo-se lodo da zona anóxica para a zona anaeróbia, recirculação "r". Na zona anóxica a concentração de nitrato é mantida baixa através do controle da taxa de recirculação "a" (Figura 10), de tal maneira que o nitrato disponível para desnitrificação na zona anóxica se iguala à capacidade de desnitrificação nesta.

O sistema UCT modificado foi desenvolvido para assegurar que não haja introdução de nitrato, mesmo quando a concentração de nitrato e da taxa de desnitrificação varia com o tempo. A zona anóxica do pré-desnitrificante está dividida em duas, descarregando-se o lodo de retorno do decantador na primeira parte e na segunda parte o lodo proveniente do reator aeróbio. Nessas condições, a remoção de nitrato na primeira parte será completa, havendo total proteção da zona anaeróbia, favorecendo assim a remoção de fósforo. Porém, ao configurar as zonas anóxicas dessa maneira, o efluente pode apresentar maiores concentrações de nitrato, visto que não existe uma zona anóxica para pós-desnitrificação e pode acarretar problemas como flotação do lodo no decantador secundário.

Figura 10: Representação esquemática de um sistema de lodo ativado pelo processo UCT com 5 reatores sequenciais (anaeróbio-anóxico-aeróbio-anóxico-aeróbio).

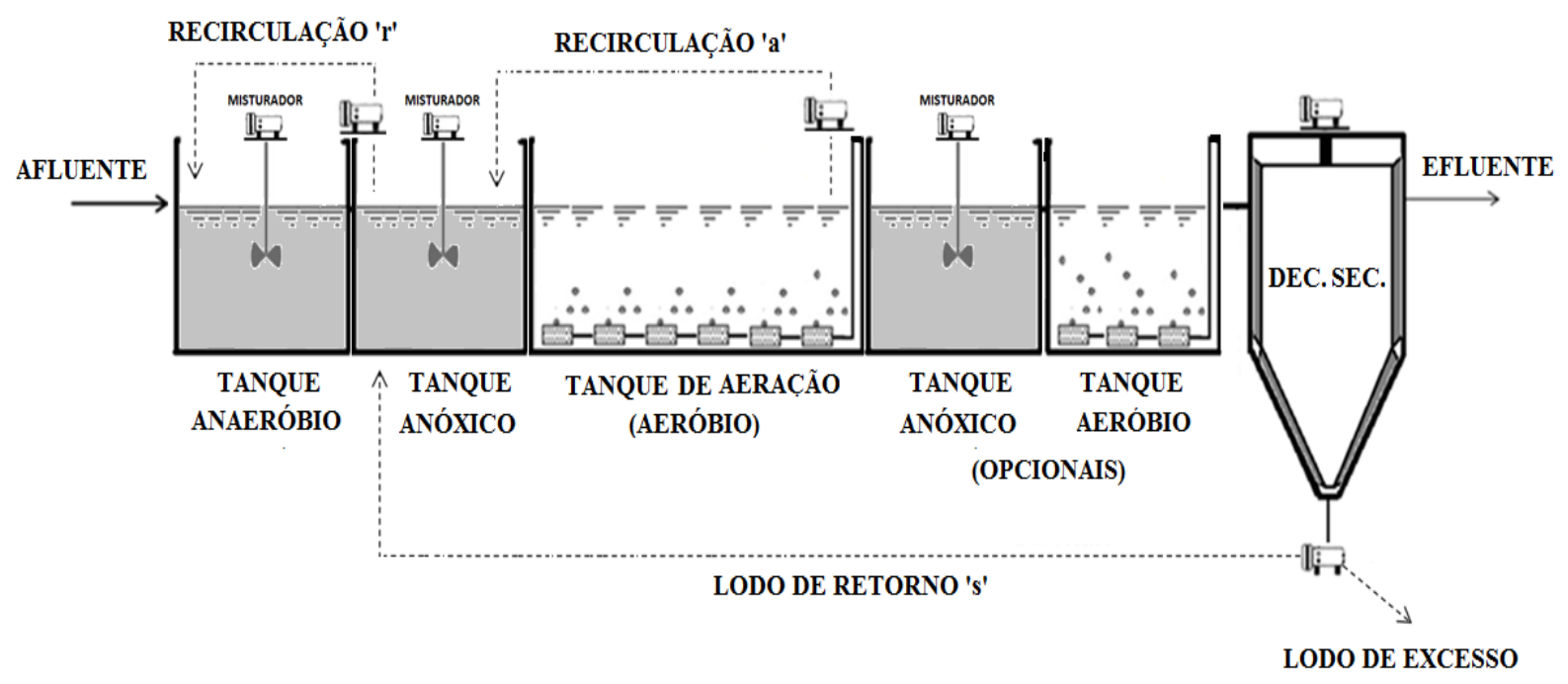




\subsubsection{Processo SHARON}

O processo SHARON (Single Reactor High Activity Ammonia Removal Over Nitrite) propõe a eliminação de nitrogênio em um único reator via nitrito. Embora não seja adequado para o tratamento de todos os tipos de águas residuárias, devido à alta dependência com a temperatura, este processo é ideal para a remoção de nitrogênio de efluentes com alta concentração amoniacal (SCHMIDELL e REGINALTTO, 2005; AHN, 2006). Nesse processo se estabelece um curto-circuito nos processos de nitrificação e desnitrificação. Um grupo de investigadores da Universidade Técnica de Delft na Holanda desenvolveu esse processo que é capaz de nitrificar parcialmente águas residuais e produzir quantidades consideráveis de nitrito (Hellinga et al., 1998). A nitrificação é interrompida numa etapa intermediária, em que a oxidação da amônia cessa na forma de nitrito para numa próxima etapa, sem aeração, haver conversão de nitrito a nitrogênio gasoso, economizando, dessa forma, energia e doadores de elétrons. A oxidação para nitrito só requer $3 / 4$ da demanda de oxigênio necessário para a oxidação para nitrato como também a desnitrificação do nitrito requer apenas 3/5 do material orgânico necessário para a remoção do nitrato (SCHMIDT et al., 2003). O sistema SHARON é operado sob curtos tempos de detenção hidráulica, altas temperaturas $\left(30^{\circ} \mathrm{C}\right.$ a $\left.35^{\circ} \mathrm{C}\right)$, elevadas vazões específicas de alimentação (alta concentração de amônia no efluente) e sem recirculação (VAN DONGEN, 2001). As reações envolvidas poderiam ser representadas segundo as Equações (24) e (25) (MULDER e KEMPEN, 1997).

\section{Nitritação:}

$\mathrm{NH}_{4+}+1,5 \mathrm{O}_{2} \rightarrow \mathrm{NO}_{2-}+\mathrm{H}_{2} \mathrm{O}+2 \mathrm{H}_{+}$

\section{Desnitritação:}

$6 \mathrm{NO}_{2}-+3 \mathrm{CH}_{3} \mathrm{OH}+3 \mathrm{CO}_{2} \rightarrow 3 \mathrm{~N}_{2}+6 \mathrm{H}_{2} \mathrm{CO}_{3}-+3 \mathrm{H}_{2} \mathrm{O}$

Geralmente, a nitritação é realizada sem retenção de lodo, em um TRH de 1 dia, temperatura que varia na faixa de 30 a $40 \stackrel{\circ}{\circ}$ e valores de $\mathrm{pH}$ entre 6,6 e 7. Sob essas condições, o processo de nitrificação é estável, tendo o nitrito como produto final 
(AHN, 2006). Fux et al. (2004) determinam que, para a operação em escala industrial, são recomendados reatores CSTR ou RBS com biomassa em suspensão. Baseados em experimentos com reatores de leito móvel com biofilme (MBBR), tanto em escala laboratorial quanto em escala piloto, descreveram que nenhum dos critérios de seleção aplicados como alta carga de amônio, alta concentração de amônia livre ou baixa concentração de OD levaram à seletiva supressão da oxidação de nitrito. Os mesmos autores ainda afirmaram que a produção de nitrito sem o acúmulo de nitrato em sistemas com biofilme pode não ser confiável, em virtude de o controle da idade do lodo ser dificultoso em tais sistemas.

\subsubsection{Processo ANAMMOX}

ANAMMOX (Anaerobic Ammonium Oxidation) que é realizado por microrganismos autotróficos e dispensa adição de fonte externa de carbono (JETTEN et al., 1999 apud VAN HAANDEL et al., 2009 In: PROSAB - Livro 2, Capítulo 6). Esse processo também já é operado em escala real e combina parte do nitrogênio, na forma de nitrito, com o nitrogênio amoniacal excedente e transforma a amônia a nitrogênio gasoso sob condições anaeróbias, reduzindo significativamente o consumo de oxigênio e DQO na Fase de desnitrificação (MULDER et al., 1995). O processo ANAMMOX geralmente requer um passo anterior de nitrificação parcial, que converte em nitrito parte do amônio presente no afluente. O nitrito pode ser produzido pelo processo SHARON à montante do tanque ANAMMOX, convertendo cerca de 50\% do amônio afluente em nitrito (VILLAVERDE, 2004). O processo envolve a oxidação de amônia com nitrito funcionando como aceptor final de elétrons para gerar nitrogênio gasoso (Equação 26). Além disso, os microrganismos que estão vinculados a esse processo utilizam $\mathrm{CO}_{2}$ como única fonte de carbono (Equação 27). A estequiometria do processo Anammox baseada no balanço de culturas enriquecidas está representada na Equação 28 (AHN, 2006).

$$
\mathrm{NH}_{4+}+\mathrm{NO}_{2-} \rightarrow \mathrm{N}_{2}+2 \mathrm{H}_{2} \mathrm{O}
$$


$\mathrm{CO}_{2}+\mathrm{NO}_{2-}+\mathrm{H}_{2} \mathrm{O} \rightarrow \mathrm{CH}_{2} \mathrm{O}+2 \mathrm{NO}_{3-}$

$\mathrm{NH}_{4+}+1,32 \mathrm{NO}_{2-}+0,066 \mathrm{HCO}_{3-}+0,13_{\mathrm{H}_{+}} \rightarrow 0,066 \mathrm{CH}_{2} \mathrm{O}_{0,5} \mathrm{NO}_{, 15}+1,02 \mathrm{~N}_{2}+0,26 \mathrm{NO}_{3}$

$0,26 \mathrm{NO}_{3}+0,26 \mathrm{NO}_{3}-2,03 \mathrm{H}_{2} \mathrm{O}$

Esta estequiometria indica um crescimento autotrófico limitado, ocasionado processos cujos "start-up" são bastante longos para permitir a obtenção de velocidades de processo mais adequadas. A estequiometria descrita propõe um fator de conversão de $0,11 \mathrm{gSSV} / \mathrm{gNH}^{+}-\mathrm{N}$ consumido, considerando as células com fórmula mínima $\mathrm{CH}_{2} \mathrm{O}_{0,5} \mathrm{~N}_{0,15}$ (Schmidell e Reginaltto, 2005). Este fator é ainda menor que o observado para a oxidação de amônio a nitrato. O produto principal do processo Anammox é o $\mathrm{N}_{2}$, embora $10 \%$ do nitrogênio alimentado seja convertido em nitrato ( $\mathrm{AHN}, 2006$ ). Deve-se tomar cuidado ao se operar o processo Anammox, tendo em vista o efeito inibitório imposto ao sistema quando operado na presença de oxigênio, ainda que a inibição seja reversível com a eliminação do inibidor $\left(\mathrm{O}_{2}\right)$.

\subsubsection{Processos SHARON e ANAMMOX acoplados}

Como já descrito, a eliminação de nitrogênio pode ser realizada pela oxidação anaeróbia de amônio (Processo Anammox). Entretanto, uma parcela do substrato sob a forma de amônio deve ser oxidada a nitrito (mas não a nitrato), antes que seja alimentado ao processo Anammox. Essa conversão poderia ser realizada pela parte aeróbia do processo SHARON. Desta forma, os dois processos (SHARON e Anammox), poderiam ser acoplados, congregando-os em um processo único. Um sistema combinado para a remoção de nitrogênio baseada na nitritação parcial com o processo Anammox tem muitas vantagens. Além de não necessitar a adição de carbono externa, gera pouca quantidade de lodo e requer menos energia e oxigênio que o processo convencional (AHN, 2006). Quando os dois processos mencionados são agrupados, o modo operacional do processo SHARON é modificado para a nitritação parcial (conversão de 55-60\% de amônio em nitrito) sem desnitrificação heterotrófica, permitindo condições adequadas para a reação Anammox, que completaria a degradação da amônia e nitrito, gerando nitrogênio gasoso e, em menor 
proporção, nitrato. No processo SHARON/Anammox, praticamente todo o nitrito é degradado e a maior parte do nitrogênio é liberado na forma de $\mathrm{N}_{2}$. Pequena parcela do nitrogênio presente no efluente final é atribuída ao nitrato. Jetten et al. (1997) reportaram que o processo SHARON-Anammox, quando tratando efluente de digestor, atingiu remoções de nitrogênio amoniacal de $83 \%$ quando a carga total de nitrogênio foi em torno de $0.8 \mathrm{kgN} \cdot \mathrm{m}^{-3} \cdot \mathrm{d}^{-1}$. A Figura 11 mostra o fluxograma de um processo SHARON associado ao Anammox.

Figura 11: Processo SHARON associado à ANAMMOX ANÓXICO. Fonte: Van Dongen et al. (2001).

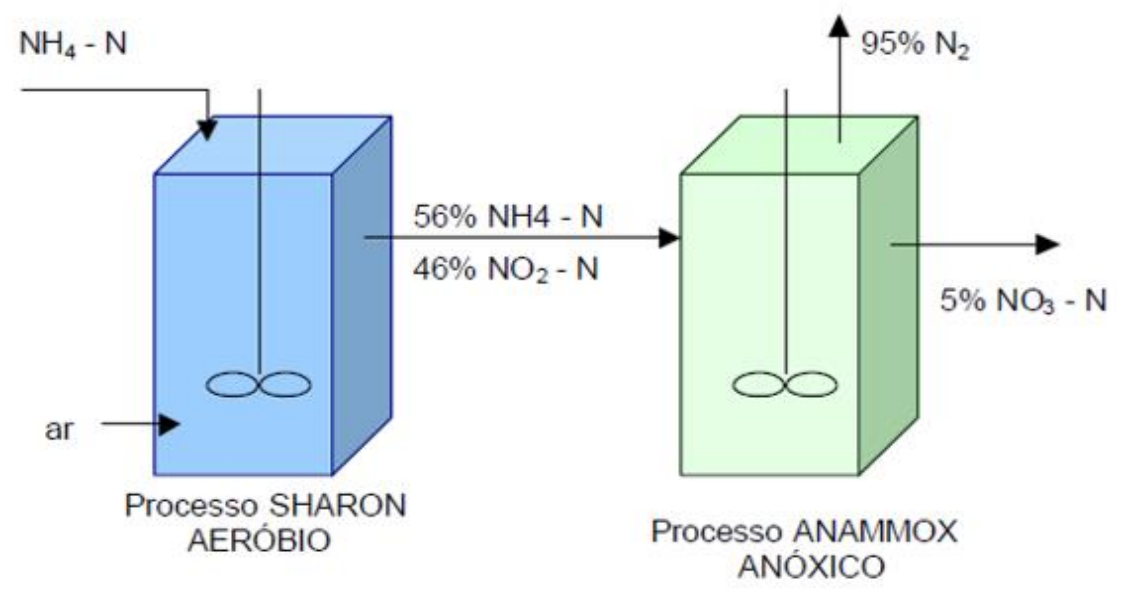

\subsubsection{Processo CANON}

O conceito embutido por trás do processo Canon (Completely Autotrophic Nitrogenremoval Over Nitrite) é também a combinação da nitritação parcial e reação Anammox, embora esse processo congregue as duas etapas (Equações 29 - 31) em um único reator aerado, implicando que os microrganismos aeróbios (Nitrosomonas) e os microrganismos anaeróbios (Planctomicetos) atuem em cooperação durante todo o processo (AHN, 2006). Os microrganismos nitrificantes seriam responsáveis pela oxidação de amônia a nitrito, consumindo boa parte do oxigênio e criando condições anóxicas para o processo Anammox, tendo em vista que as bactérias anaeróbias autotróficas atuantes neste último processo, responsáveis pela conversão de amônia e nitrito em nitrogênio gasoso, são reversivelmente inibidas por baixas concentrações 
de OD. Desta maneira, uma cooperação simbiótica estaria ocorrendo entre as populações de microrganismos presentes no reator (AHN et al., 2006; SCHIMIDELL e REGINATTO, 2005).

Eq. (29)

$\mathrm{NH}_{4+}+0,75 \mathrm{O}_{2}+\mathrm{HCO}_{3-} \rightarrow 0,5 \mathrm{NH}_{4+}+0,5 \mathrm{NO}_{2-}+\mathrm{CO}_{2}+1,5 \mathrm{H}_{2} \mathrm{O}$

$\mathrm{NH}_{4+}+1,32 \mathrm{O}_{2}+0,066 \mathrm{HCO}_{-}+0,13 \mathrm{H}+\rightarrow 0,066 \mathrm{CH}_{2} \mathrm{O}_{0,5} \mathrm{~N}_{0,15}+1,02 \mathrm{~N}_{2-}+0,26 \mathrm{NO}_{3-+}^{-+}$ $2,03 \mathrm{H}_{2} \mathrm{O}$

Eq. (31)

$\mathrm{NH}_{4+}+0,85 \mathrm{O}_{2} \rightarrow 0,44 \mathrm{~N}_{2-}^{-}+0,11 \mathrm{NO}_{3}^{-}+1,43 \mathrm{H}_{2} \mathrm{O}+0,14 \mathrm{H}^{+}$

\subsubsection{Processo OLAND}

Kuai e Verstraete (1998) apud Schmidell e Reginatto (2005), mostraram a possibilidade de efetuar a eliminação direta de nitrogênio a partir doamônio, em condições de limitação de OD. Este processo foi denominado "Oxygen Limited Autotrophic Nitrification Denitrification", ou simplesmente processo OLAND. A chave para este processo é o fornecimento de oxigênio, fazendo-se com que a nitrificação ocorra apenas até o nitrito. Posteriormente, devido às baixas concentrações de $\mathrm{OD}, \mathrm{O}$ nitrito é consumido para a oxidação de amônio. A limitação do fornecimento de OD ocasiona redução na velocidade específica de respiração celular. O processo OLAND pode ser realizado segundo as Equações 32 e 33, culminando na Reação global (Eq. 34) (Verstraete e Philips, 1998 apud Schmidell e Reginatto, 2005).

$0,5 \mathrm{NH}_{4+}+0,75 \mathrm{O}_{2} \rightarrow 0,5 \mathrm{NO}_{2-}+0,5 \mathrm{H}_{2} \mathrm{O}+\mathrm{H}^{+}$

$0,5 \mathrm{NH}_{4+}+0,5 \mathrm{O}_{2} \rightarrow 0,5 \mathrm{~N}_{2}+\mathrm{H}_{2} \mathrm{O}$ 


\section{Reação global}

$\mathrm{NH}_{4+}+0,75 \mathrm{O}_{2} \rightarrow 0,5 \mathrm{~N}_{2}+1,5 \mathrm{H}_{2} \mathrm{O}+\mathrm{H}^{+}$

A necessidade de se contar com uma cultura enriquecida em Nitrosomonas ou uma cultura pura destes microrganismos é crucial para que se consiga parar o processo nitrificante em nitrito (Schmidell e Reginatto, 2005).

\subsubsection{Sistemas cíclicos de lodos ativados (SCLA)}

Um dos processos de lodos ativados utilizados para remoção de matéria orgânica, nitrogênio e fósforo é o sistema em bateladas sequenciais (RBS). Segundo Jordão e Pessoa (2011), a constituição dos RBS se dá da seguinte forma:

- 1a Fase (Alimentação ou Enchimento) - o efluente é alimentado ao reator. Durante o enchimento o sistema de aeração fica desligado, ocorrem às reações de degradação da matéria orgânica e a formação do floco que irá sedimentar.

- $2^{\mathrm{a}}$ Fase (Aeração e reação) - ocorre a mistura do lodo com efluente e ar dissolvido. Nesta etapa os aeradores permanecem ligados.

- $3^{\text {a }}$ Fase (Sedimentação) - os aeradores são desligados, e os sólidos em suspensão sedimentam no interior do tanque.

- 4 $4^{a}$ Fase (Descarga do efluente) - o efluente clarificado tratado é removido pela parte superior do tanque, enquanto que a massa biológica permanece no reator.

- 5a Fase (Repouso ou ajustes) - ajuste do tempo entre o fim de um ciclo e o início de outro. $O$ excesso de lodo também é removido nessa fase.

Para operar um reator sequencial é preciso dividi-lo em duas partes superpostas: A zona de carga e a zona de lodo. Na zona de carga, ocorre o enchimento e esvaziamento do reator, o que determina a intermitência do fluxo do esgoto. Enquanto na zona de lodo é acumulado todo o lodo do reator, quando completada a sua sedimentação, uma vez decorrido o tempo de duração da sedimentação. O sistema cíclico de lodo ativado (SCLA) é uma variante do RBS, porém com três zonas de 
reação comunicantes com fluxo contínuo entre as zonas, associados a uma recirculação interna de lodo, durante a fase ativada de cada ciclo, conforme descreve Goronszy, et. al.(1995). A zona 1 recebe o esgoto bruto e parte da biomassa da zona 3, funciona como um bio-seletor. A zona 2 possui mistura hidráulica, é aqui que a maior fração de nitrogênio total é removida do sistema. A zona 3 contém a maior parte da biomassa do sistema. A Erro! Fonte de referência não encontrada.12 mostra o e squema básico de distribuição dessas zonas no SCLA.

Figura 12: Esquema básico de distribuição das zonas do SCLA

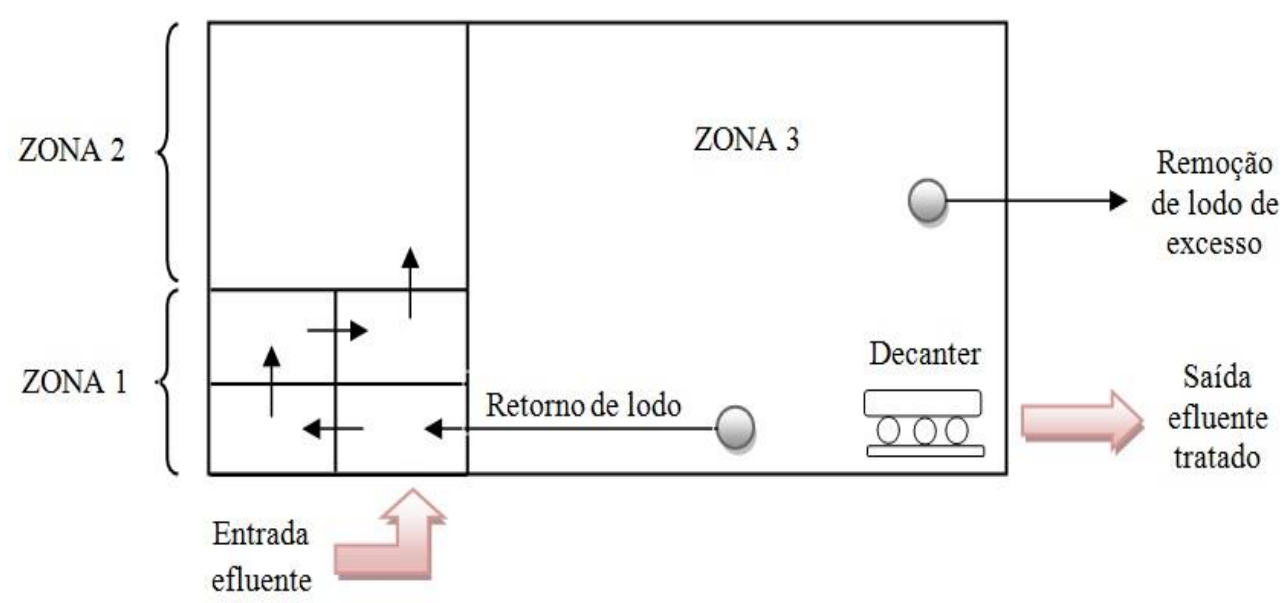

Fonte: Adaptado de Goronszy, et. al.(1995).

Para aplicações com esgoto sanitário as relações relativas ao volume dessas zonas são tipicamente 1:2: 17. A biomassa presente na zona 1 normalmente não é aerada e apresenta a maior atividade metabólica das três zonas devido as condições de alta carga orgânica que recebe do esgoto bruto. As reações nessa zona são essencialmente anóxicas-anaeróbias, removem principalmente a parcela rapidamente biodegradável do esgoto e possibilitam a desnitrificação, devido ao reciclo do lodo da zona 3 contendo nitrato. A concentração de sólidos no reciclo de lodo pode variar de $3500-5000 \mathrm{mg} / \mathrm{L}$ durante a fase aerada e pode chegar a $15.000 \mathrm{mg} / \mathrm{L}$ durante a fase não aerada. As condições da biomassa nas zonas 2 e 3 são sequencialmente expostas a simultâneas repetições anóxica-aerada e anaeróbias, isso é possível mediante ao controle do oxigênio dissolvido, regulando e interrompendo o seu suprimento ou pelo controle do potencial de oxirredução (ORP) que representa a capacidade de oxidação (ganha de elétrons) ou redução (perda de elétrons) de um efluente e pode variar de $-150 \mathrm{mV}$ e 100mV (GORONSZY, et al., 1993; DEMOULIN G. 
et al., 1997). A presença da zona 1 (bio-seletora) promove uma vantagem competitiva aos organismos acumuladores de fósforo (OAPs): estes são capazes de armazenar ácidos orgânicos voláteis (AOVs) na forma de poli- $\beta$-hidroxibutirato (PHB) utilizando energia proveniente da quebra e liberação do polifosfato previamente acumulado em suas células. Para o desenvolvimento dos OAPs é preciso que AOVs estejam presentes, o que deve ocorrer já que são produtos da fermentação realizada pelos organismos heterótrofos facultativos sobre a DQO rapidamente biodegradável do esgoto bruto (ALEM SOBRINHO, 1991). Na zona 3, em seu processo metabólico, os OAPs utilizam como substrato o PHB armazenado e como aceptor de elétrons o oxigênio do meio líquido de forma a obter crescimento celular e produzir polifosfato. Ao serem retornados à zona 1 , esses organismos carregam o polifosfato produzido na etapa aeróbia, que servirá como fonte de energia para armazenamento dos AOVs nessa zona, fechando o ciclo. Este processo de recirculação é responsável pelo aumento da concentração de sólidos em suspensão e o tempo de contato com o efluente, sendo que a permanência elevada desses microorganismos garante a eficiência do processo (JORDÃO e PESSOA, 2011). Assim a remoção do fósforo é obtida a partir do descarte do lodo da zona 3, rico em fósforo. O tempo do ciclo pode variar de acordo com a necessidade e características do esgoto a ser tratado. Goronszy, et. al. (1995), operou o SCLA em escala real, tratando esgoto sanitário típico. O tempo de detenção hidráulica na zona 3 foi de 24 horas com vazão de retorno de lodo de $20 \%$ da vazão média de alimentação. As etapas de alimentação, reação, sedimentação e descarte do esgoto tratado foram de 60 minutos cada. A concentração de sólidos em suspensão no tanque de aeração foi de 3500-5000mg/L e, concentração de OD na faixa de 0,0 - 2,5 $\mathrm{mgO}_{2} / \mathrm{L}$. O estudo avaliou a remoção biológica de DQO onde se obteve uma eficiência maior que 96,7\%. Em relação aos nutrientes os resultados se mostraram muito promissores com eficiências de 98,6\% de amônia e 91,4\% de fósforo. Ainda segundo o autor, as eficiências não sofreram significativas mudanças mesmo em condições de picos de vazão e em baixas temperaturas. No estudo publicado por Li Ying et al. (2011), foi posto em operação um SCLA em escala piloto, tratando esgoto doméstico com elevada concentração de nitrogênio amoniacal. O tempo de detenção hidráulico na zona 3 foi de 16 horas com variação na vazão de retorno de lodo em 50\%, 100\%, 150\%, 200\% e 250\%, da vazão média de alimentação. As etapas de alimentação e reação foram de 60 minutos, a de 
sedimentação de 90 minutos e o descarte do esgoto tratado de 20 minutos. A concentração de sólidos em suspensão no tanque de aeração foi de 4.000-4.500mg/L e, concentração de OD na faixa de 2,5 - 3,0 $\mathrm{mg} \mathrm{O} / \mathrm{L}$. O estudo avaliou a remoção biológica de $\mathrm{DQO}$ e nitrogênio amoniacal onde se obteve uma eficiência maior que 97\% e 88\%, respectivamente. Essa eficiência se deu com a vazão de retorno de lodo de $150 \%$. Os autores citam que para vazões acima desse valor a eficiência do sistema reduz consideravelmente.

\subsubsection{Reatores de leito móvel com biofilme (MBBR - Moving-bed biofilm reactor)}

Um reator de leito móvel (MBBR) utiliza elementos plásticos de suporte de baixa densidade imersos na massa líquida para crescimento de biomassa, mantidos no reator pelo uso de grades ou peneiras. Pode ser aplicado tanto em ambiente aeróbio quanto anóxico, sendo a agitação dos reatores obtida, em tanques aeróbios, pelo sistema de aeração difusa utilizada para o fornecimento de ar para o processo, e as unidades anóxicas misturadas com misturadas com misturados submersíveis de baixa velocidade (CAMPOS, 2014). Um MBBR não depende de recirculação de biomassa aderida aos suportes móveis já deve ser suficiente para a degradação dos compostos poluentes desejados. Os sistemas de MBBR podem ser utilizados para tratamento de esgotos domésticos ou de efluentes industriais. As primeiras plantas instaladas na Noruega ainda não apresentam sinais de desgaste dos suportes plásticos em mais de 15 anos de operação contínua (WEF, MOP N. 11, 2008).

Como vantagens de reatores de biofilme de leito móvel em comparação com sistemas de lodo ativado ou sistemas de biomassa aderida de leito fixo podem ser relacionadas:

- Menor volume dos reatores biológicos se comparado com o sistema de lodo ativado conjugado com as unidades de separação de sólidos, sejam decantadores secundários ou sistemas de membranas para alcançar os mesmos objetivos de tratamento;

- As taxas de aplicação de sólidos para as unidades de separação de sólidos são significantemente reduzidas quando comparadas às de sistemas de lodo ativado; 
- Não há necessidade de operações de retro lavagem para controle da espessura de biofilme ou desentupimento do meio suporte por se tratar de reatores de mistura completa e fluxo contínuo;

- Apresentam a flexibilidade de sistemas de lodo ativado para manobras no fluxograma de processo para alcance de objetivos específicos de tratamento sem a necessidade de bombeamento de retorno de lodo.

- É uma alternativa que apresenta uma reduzida quantidade de intervenções para a adequação de plantas existentes de tratamento de esgotos domésticos.

Rusten et al. (1995) desenvolveram pesquisa com MBBR em sistema com reatores em série envolvendo pré-desnitrificação por meio de recirculação interna. $O$ esgoto utilizado na pesquisa, desenvolvida na Noruega, demonstrou-se diluído e de baixa alcalinidade, recebendo anteriormente apenas tratamento preliminar. A temperatura ambiente era inferior a $10^{\circ} \mathrm{C}$.

\subsubsection{Lodo granular aeróbio (AGS - Aerobic granular sludge).}

Recentemente, estudos referentes à granulação aeróbia em reatores em bateladas sequenciais vêm sendo realizados, uma vez que tal processo gera uma biomassa ativa com características diferenciadas, quando comparadas aos sistemas de lodos ativados convencionais, que podem otimizar tal sistema. Nesta seção será apresentado o processo de granulação aeróbia, as características do lodo granular aeróbio (LGA) e sua diferenciação em relação aos flocos de lodos ativados, os fatores que influenciam no processo de formação do lodo granular aeróbio, bem como estudos de aplicação desta tecnologia no tratamento de esgoto industrial, doméstico, sintético, e em escala real. A separação eficiente do lodo a partir do efluente tratado sempre foi o foco de pesquisadores, uma vez que tal processo é de grande importância no desempenho de sistemas de tratamento de esgoto (LI et al., 2006).

Estudos referentes ao LGA foram realizados por diversos autores ao longo dos anos (SCHMIDT \& AHRING, 1996; GONZALEZ-GIL et al., 2001; LEE et al., 2004; MOLINA et al., 2008; MEULEPAS et al., 2010; BASSIN, 2012). O LGA vem ganhando o interesse de estudiosos por possuir, como principal característica, boas propriedades de sedimentação. O LGA apresenta diversas vantagens sobre os flocos aeróbios de lodos ativados, tais como a matriz coesa e forte, rápida sedimentação característica, 
retenção de biomassa elevada e capacidade de resistir a elevadas cargas orgânicas (NOR-ANUAR et al., 2012). De acordo com Liu et al. (2005), a granulação aeróbia pode ser definida como um processo de agrupamento de células por meio de autoimobilização, formando-se então, uma associação estável e multicelular. Segundo Di laconi et al. (2007), em sistemas com biomassa granular, a mesma cresce como grânulos microbianos compactos e densos, permitindo maior retenção de biomassa. Em comparação aos flocos de lodos ativados, os grânulos aeróbios possuem características diferentes, como estrutura física regular, forte e densa, excelente capacidade de sedimentação, elevada retenção de biomassa e capacidade de tratar esgotos com alta concentração e suportar cargas de choque. (LIU \& TAY, 2004). Além disso, quando o grânulo aeróbio tem estrutura compacta com tamanho entre 0,5 e $2 \mathrm{~mm}$, a resistência à transferência de massa, principalmente oxigênio, é maior do que no floco de lodo ativado convencional (LIU \& TAY, 2006). Segundo De Kreuk (2006), a remoção de nutrientes por meio de grânulos aeróbios é semelhante ao mecanismo utilizado em sistemas convencionais de lodos ativados, podendo ocorrer o processo de nitrificação e desnitrificação simultâneas. De acordo com Bueno (2011), nitrificação e desnitrificação simultâneas (NDS) implicam que os dois processos ocorrem no mesmo reator sob condições de operação idênticas. No processo de NDS, o oxigênio dissolvido e o substrato solúvel presentes na parte exterior do floco difundem-se na zona aeróbia. De acordo com a concentração de oxigênio dissolvido, amônia e DQO biodegradável, o oxigênio dissolvido poderá ser consumido rapidamente no interior do floco tornando-se indisponível na camada interna. O nitrato produzido na zona aeróbia pode difundir-se em direção à camada interna em conjunto ao substrato, ocorrendo a desnitrificação. A remoção de nutrientes por meio de grânulos aeróbios pode ser obtida por diferentes zonas, anaeróbias, anóxicas e aeróbias, no interior do grânulo. A existência dessas zonas cria um ambiente favorável para o crescimento de bactérias facultativas e aeróbias, fazendo com que seja possível a remoção de carbono, nitrogênio e fósforo simultaneamente em um único reator (JUNGLES, 2011; BASSIN, 2012). Segundo Bassin (2012), na estrutura dos grânulos aeróbios ocorrem processos simultâneos, sendo que na fase anaeróbia, cria-se uma zona também anaeróbia no grânulo que libera fosfato e acumula polihidroxialcanoatos através da conversão de DQO (ácidos graxos voláteis), conforme se observa na Figura 13. Os processos de nitrificação e desnitrificação ocorrem simultaneamente nas diferentes camadas dos 
grânulos aeróbios durante a fase aeróbia do sistema. Na região externa ocorre a nitrificação, onde há as bactérias autotróficas nitrificantes. $O$ nitrito e 0 nitrato formados durante o processo de nitrificação podem difundir-se para o interior do grânulo, região com características anóxicas, e assim serem desnitrificados. Os PHAs que foram armazenados durante a fase anaeróbia podem exercer função de doador de elétrons para o processo de desnitrificação, sendo esta etapa geralmente associada à remoção anóxica de fosfato, processo denominado de desfosfatação desnitrificante, realizado por organismos acumuladores de polifosfato desnitrificantes (DPAO).

Figura 13: Zonas aeróbia, anóxica e anaeróbia em grânulos aeróbios. Fonte: Adaptado de Bassin, 2012.
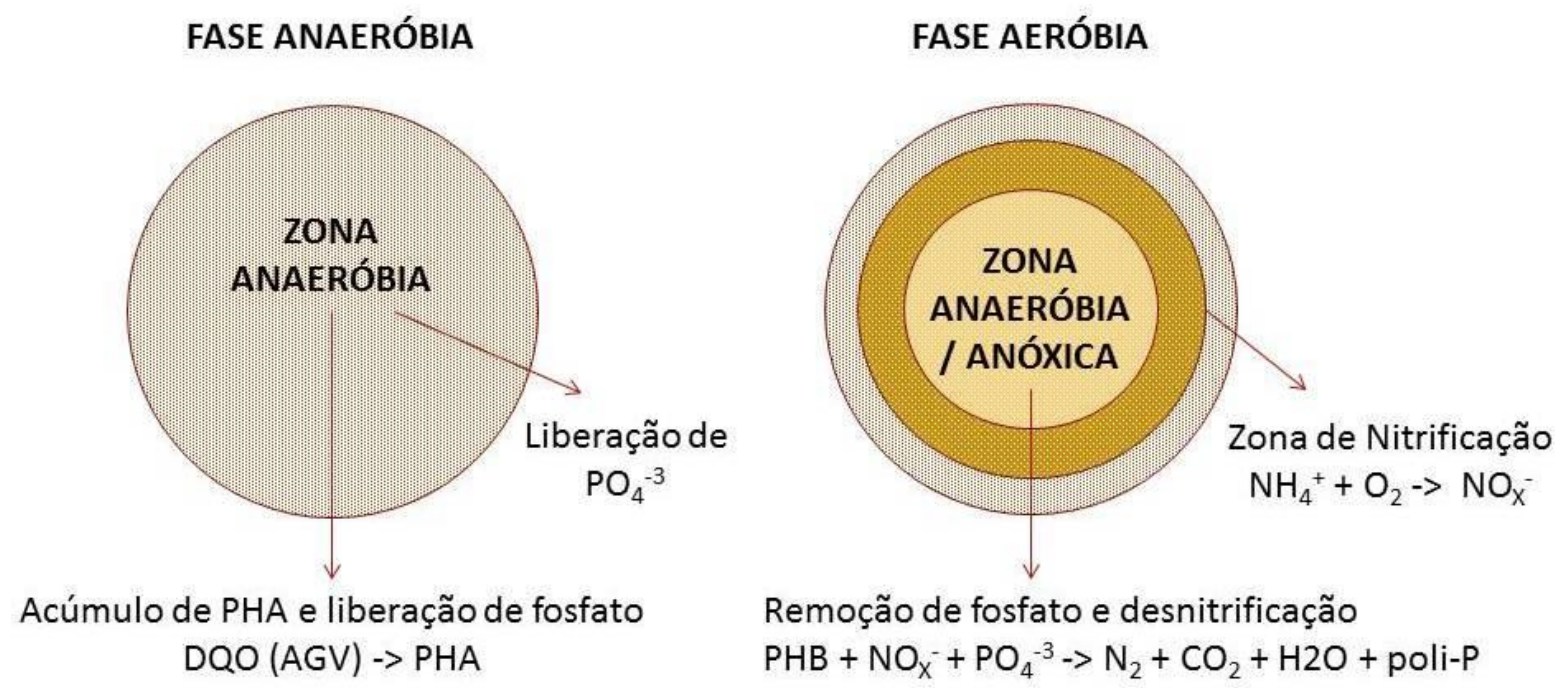


\subsection{Nitrificação e Desnitrificação Simultânea (NDS) em processos de lodos ativados}

\subsubsection{Fundamentos}

A remoção de nitrogênio em sistemas de reator único tem sido proposta desde o início da tecnologia de sistemas de lodo unitário (PASVEER, 1969; MATSCHÉ, 1970 apud VAN HAANDEL et al., 2009), mas, recentemente, tem-se visto vários artigos propondo de novo este método. Nos primeiros dias de remoção biológica de nitrogênio, normalmente usava-se aeradores de superfície que eram muito populares na época. Neste caso, a estratificação de OD em reatores aeróbios pode ser muito grande, o que facilitava o desenvolvimento de regiões anóxicas no licor misto (onde a desnitrificação ocorre). Isto é mais provável na medida em que o reator é mais profundo, criando, desta forma, uma distância maior entre os pontos de OD mínimo e máximo (perto dos aeradores). Como a demanda de oxigênio é variável e geralmente se aplica uma aeração estática, a concentração de OD variará com o tempo e estas zonas anóxicas terão volume variável. Por esta razão, a magnitude da desnitrificação é irregular: quando a carga é baixa, a demanda de oxigênio será pequena, a concentração de OD alta e a desnitrificação limitada. Em momentos de maior carga, a desnitrificação se desenvolverá mais, mas poderá haver nitrificação incompleta devido à falta de oxigênio dissolvido. No entanto, nos últimos anos, tem-se observado um grande interesse pela remoção de nitrogênio em reator unitário pelo processo de nitrificação e desnitrificação simultânea, devido ao uso de aeração por ar difuso (que é introduzido no fundo do reator), neste caso haverá menos estratificação e, mediante ao uso de um sistema automatizado de controle da concentração de OD que pode ser ajustado para atender as variações de carga. A remoção biológica de nitrogênio nessas condições pode ser obtida com ótimo desempenho e estabilidade, como pode ser observada nesse estudo.

\subsubsection{Condições necessárias para nitrificação e desnitrificação simultânea}

Nitrificação e desnitrificação simultâneas (NDS) implicam que os dois processos ocorrem no mesmo reator sob condições de operação idênticas. Segundo Pasveer, 
1969 e Matsché, 1970 apud Van Haandel (2009), uma quantidade significativa de nitrogênio pode ser removida em um sistema de lodos ativados de estágio único sem que haja uma região específica em condições anóxicas. Esta observação foi feita em lodos ativados com mistura completa com aeradores superficiais em valos de oxidação, sistemas com tempo de retenção hidráulica e de residência celular elevado, nas quais os processos de nitrificação e desnitrificação podem ocorrer simultaneamente, havendo regiões de baixa concentração de oxigênio dissolvido no lodo do tanque de aeração, seu consumo torna o ambiente favorável para o surgimento de reações anóxicas. O oxigênio dissolvido e o substrato solúvel presentes na parte exterior do floco difundem-se na zona aeróbia e, dependendo da concentração de oxigênio dissolvido, de amônia e de DQO biodegradável, o oxigênio dissolvido poderá ser consumido rapidamente no interior do floco de forma que se torna indisponível na camada interna. O nitrato produzido na zona aeróbia pode difundir-se em direção à camada interna conjuntamente com o substrato, ocorrendo a desnitrificação, conforme a ilustração da Figura 14.

Figura 14: Esquema dos transportes e transformações que podem ocorrer em um floco em meio com baixa concentração de oxigênio dissolvido. Fonte: Adaptado de (METCALF \& EDDY, 2013).

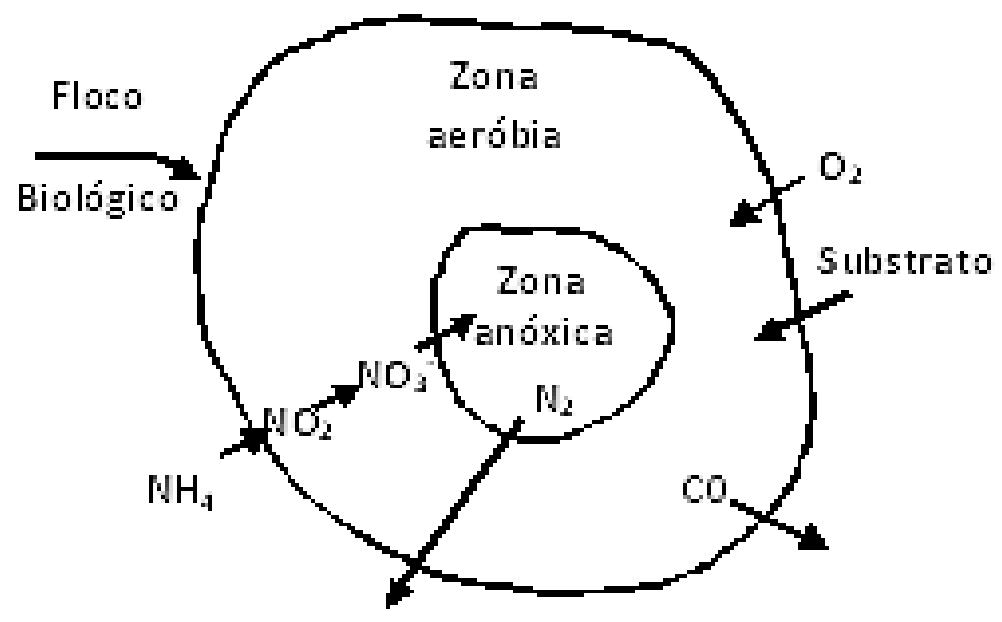

Considerando-se que pode ocorrer desnitrificação aeróbia, muitos autores (ROBERTSON e KUENEN, 1984; RITTMANN e LANGELAND, 1985; POTH, et al., 1985; HELMER et al., 1998; VAN LOOSDRECHT e JETTEN, 1998; YOO, et al. 1999; POCHANA e KELLER, 1999; VILLABERDE et al., 2000; ZHANG et al., 2001; SATOH 
et al, 2003), realizaram experimentos com nitrificação e desnitrificação simultâneas em reatores aeróbios e levantaram as seguintes hipóteses sobre o processo de NDS:

(a) de natureza física ("teoria de microambiente"): os gradientes de concentração de OD dentro dos flocos ou biofilmes microbianos (de diâmetro de 100 a $150 \mu \mathrm{m}$ ) formam populações diferenciadas ao longo do biofilme devido às limitações difusionais: as nitrificantes ocupam zonas de altas concentrações de OD e as desnitrificantes localizam-se em regiões de concentrações mais baixas;

(b) de natureza biológica: existência de bactérias desnitrificantes aeróbias e nitrificantes heterotróficas. Supõe-se que os microrganismos responsáveis pela desnitrificação são capazes de reduzir nitrogênio por determinado tempo, mesmo quando a concentração de oxigênio dissolvido começa a aumentar, considerando que a biomassa esteja submetida a baixas concentrações de OD.

(c) de controle operacional e ambiental: O controle automatizado da concentração de OD em baixas concentrações é um fator "chave" para o desenvolvimento e estabilidade do processo NDS; Elevado tempo de retenção de sólidos (TRS); Matéria orgânica disponível; Temperatura que favoreçam a nitrificação

Os estudos realizados por Pochana e Keller (1999) mostraram que a adição de matéria orgânica prontamente biodegradável resulta em aumento da velocidade de desnitrificação. Stenstron e Song, apud Rusten et al. (1995), observaram que a velocidade de nitrificação não depende apenas da concentração de oxigênio dissolvido no lodo, mas também da quantidade de DBO presente. Quanto maior a DBO solúvel, a velocidade de utilização do oxigênio é maior, reduzindo a velocidade de nitrificação e a disponibilidade de oxigênio dissolvido na parte mais interna do floco. As velocidades de nitrificação e desnitrificação devem ocorrer em níveis semelhantes para que esses processos ocorram simultaneamente. A velocidade de nitrificação é reduzida pela baixa concentração de oxigênio dissolvido, enquanto que a velocidade de desnitrificação é reduzida pela baixa concentração de substrato solúvel na parte mais interna do floco. Apenas os sistemas com tempos de detenção elevados como 
os processos com aeração prolongada são capazes de acomodar simultaneamente a nitrificação e a desnitrificação. Os sistemas com pré-desnitrificação são desfavorecidos pela necessidade de razões elevadas de recirculação interna de lodo, isto é, recirculação de lodo da zona aerada para a câmara anóxica, dependendo da concentração desejada de nitrato no efluente. Os sistemas com pós-desnitrificação são dificultados pela necessidade de introdução de fonte externa de carbono para permitir a desnitrificação. O balanço de alcalinidade é essencial para o equilíbrio e avaliação dos fenômenos que ocorrem nesses processos, sendo que há consumo de alcalinidade na nitrificação e reposição de apenas parte da alcalinidade consumida aproximadamente a metade - na desnitrificação. Foram observados níveis elevados de nitrificação e desnitrificação em valos de oxidação operando com concentração de oxigênio dissolvido na faixa de 0,1 a $0,4 \mathrm{mg} \cdot \mathrm{L}^{-1}$ e com idades do lodo elevadas (RITTMAN e LANGELAND, 1985, apud TCHOBANOGLOUS, 2004). A baixa concentração de oxigênio dissolvido resulta em velocidade de nitrificação mais baixa e os flocos de lodos ativados serão mantidos apenas parcialmente aeróbios. As velocidades de nitrificação e desnitrificação são dependentes da cinética da reação, tamanho, estrutura e densidade do floco, carga de DQO rapidamente biodegradável e concentração de oxigênio dissolvido no lodo. O modelo de Monod pode ser adaptado para estimar o efeito da baixa concentração de oxigênio dissolvido nas velocidades de nitrificação e desnitrificação e no desempenho do sistema. $O$ efeito da concentração de oxigênio dissolvido sobre a idade do lodo Rs para obtenção de concentração de $\mathrm{N}-\mathrm{NH}_{4+}$ no efluente de 1,0 mg.L-1 é mostrado na Figura 15.

Figura 15: Relação entre concentração de oxigênio dissolvido e idade do lodo para obtenção de efluente com 1,0 mg.L-1 de N-NH4+, a $20^{\circ} \mathrm{C}$ para Ko= 0,5 mg.L-1.

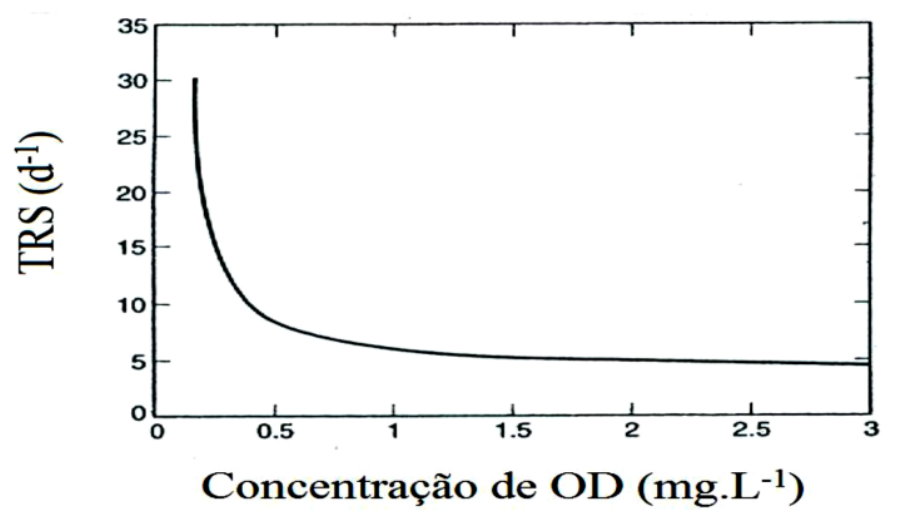


Com base na equação 35 a velocidade de nitrificação à concentração de oxigênio dissolvido de $0,2 \mathrm{mg} \cdot \mathrm{L}^{-1}$ corresponde a $24 \%$ da velocidade à concentração de oxigênio dissolvido de 2,0 mg. $\mathrm{L}^{-1}$, exigindo idades do lodo de 19,9 e 4,7 dias, respectivamente. A velocidade de desnitrificação pode ser relacionada com a velocidade de utilização do substrato conforme a equação 35 .

$$
r_{s u}=-\left(\frac{k X S}{K_{S}+S}\right)\left(\frac{N O_{3}}{K_{S, N O_{3}}+N O_{3}}\right)\left(\frac{K_{O}^{\prime}}{K_{O}^{\prime}+O D}\right) \eta
$$

Sendo:

rsu: velocidade de utilização do substrato;

k: velocidade máxima de utilização do substrato;

$\mathrm{X}$ : Concentração de biomassa;

$\mathrm{Kd}$ : Constante de meia velocidade;

$\mathrm{KS}, \mathrm{NO}_{3}$ : Constante de meia velocidade para reação limitada por $\mathrm{NO}_{3}$;

K'O: Coeficiente de inibição por oxigênio;

$\eta$ : Relação entre a taxa de utilização do substrato com $\mathrm{NO}_{3} \times \mathrm{OD}$ como aceptor de elétrons

A velocidade de utilização de nitrato pode ser relacionada com a velocidade de utilização do substrato conforme a equação acima, seguindo procedimento em que primeiro é relacionada com a velocidade de utilização de oxigênio, dada por:

Oxigênio Consumido $=\mathrm{DQO}$,removida $-\mathrm{DQO}$ lodo descartado

ro $=Q\left(S_{0}-S\right)-1,48 P_{x, \text { bio }}($ ro em kg/d e Px,bio em kgSSV/d)

Dividindo-se por V (volume do reator):

$\mathrm{ro}=-\mathrm{rsu}_{\mathrm{su}}-1,48 \mathrm{rg}_{\mathrm{g}}$

Onde:

ro : velocidade de utilização de oxigênio, $\mathrm{g} / \mathrm{m}^{3} \cdot \mathrm{d}$;

$r_{\text {su: }}$ velocidade de utilização de substrato, $\mathrm{g} / \mathrm{m}^{3} . d$;

$r_{g}$ : velocidade de crescimento líquido de biomassa, $\mathrm{g} / \mathrm{m}^{3} . \mathrm{d}$;

Mas $r_{g}=-r_{s u}-k_{d x}$ 
$\mathrm{ro}=-(1-1,48 \mathrm{Y}) \mathrm{r}_{\mathrm{su}}+1,42 \mathrm{kdX}_{\mathrm{d}}$

Semi-reações por mol de e- transferidos:

$0,25 \mathrm{O}_{2}+\mathrm{H}^{+}+\mathrm{e}^{-} \rightarrow 0,25 \mathrm{H}_{2} \mathrm{O}$

$0,20 \mathrm{NO}_{3}+1,2 \mathrm{H}^{+}+\mathrm{e}^{-} \rightarrow 0,1 \mathrm{~N}_{2}+0,6 \mathrm{H}_{2} \mathrm{O}$

$0,33 \mathrm{NO}_{3}+1,33 \mathrm{H}^{+}+\mathrm{e}^{-} \rightarrow 0,67 \mathrm{~N}_{2}+0,17 \mathrm{H}_{2} \mathrm{O}$

$0,25 \times 32 \mathrm{~g} \mathrm{O}_{2} \rightarrow 0,20 \times 14$ (em equivalentes de $\mathrm{N}$ )

Portanto: $8 \mathrm{gO}_{2} \rightarrow 2,8 \mathrm{gN}$

$E$, portanto: $\mathrm{O}_{2} / \mathrm{NO}_{3}(\mathrm{em} \mathrm{N})=8 / 2,8=2,86$

Usando 2,86 equivalentes $\mathrm{O}_{2}$ / g N-NO 3 , tem-se:

$\mathrm{rNO}=\mathrm{ro} / 2,86$

rNO3: velocidade de redução de $\mathrm{N}-\mathrm{NO}_{3}, \mathrm{em} \mathrm{g} / \mathrm{m}^{3} . \mathrm{d}$

Eq. (38)

$r_{\mathrm{NO}_{3}}=-\left(\frac{1-1,48 Y}{2,86}\right) \cdot r_{s u}+\left(\frac{1,48}{2,86}\right) k_{d} \cdot X \cdot \eta$

Eq. (39)

$r_{\mathrm{NO}_{3}}=-\left(\frac{1-1,48 Y}{2,86}\right)\left(\frac{k X S}{K_{S}+S}\right)\left(\frac{N O_{3}}{K_{S, N O_{3}}+N O_{3}}\right)\left(\frac{K_{O}^{\prime}}{K_{O}^{\prime}+O D}\right)+\left(\frac{1,48}{2,86}\right) k_{d} \cdot X \cdot \eta$

A velocidade de redução de nitrato pode ser expressa em função das concentrações de $\mathrm{DQO}$ rapidamente biodegradável, $\mathrm{N}-\mathrm{NO}_{3}, \mathrm{OD}$ e biomassa. $\mathrm{O}$ coeficiente de inibição k'0 é de difícil determinação, dependendo do tamanho e estrutura do floco. Na Figura 15, o efeito da concentração de OD na velocidade de desnitrificação é lançado em gráfico para valores de k'0 (coeficiente de inibição) de $0,02 \mathrm{mg} \cdot \mathrm{L}^{-1}$ e $0,20 \mathrm{mg} \cdot \mathrm{L}^{-1}$. $\mathrm{Na}$ Tabela 2 são apresentados os coeficientes cinéticos utilizados na construção da Figura 16. 
Tabela 2: Coeficientes cinéticos típicos do processo de nitrificação

\begin{tabular}{|c|c|c|c|}
\hline Coeficiente & Unidade & Faixa & Valor Típico \\
\hline$\mu \mathrm{nm}$ & $\mathrm{gSSV}^{-1} \cdot \mathrm{gSSV}^{-1} \cdot \mathrm{d}^{-1}$ & $0,20-0,90$ & 0,75 \\
\hline $\mathrm{KN}_{\mathrm{N}}$ & $\mathrm{gN}-\mathrm{NH}_{4}{ }^{+} \cdot \mathrm{m}^{3}$ & $0,5-1,0$ & 0,74 \\
\hline $\mathrm{Y}_{\mathrm{n}}$ & $\mathrm{gSSV}^{-1} \cdot \mathrm{gN}-\mathrm{NH}_{4}^{+}$ & $0,10-0,15$ & 0,12 \\
\hline Kdn & $\mathrm{gSSV}^{-1} \cdot \mathrm{gSSV}^{-1} \cdot \mathrm{d}^{-1}$ & $0,05-0,15$ & 0,18 \\
\hline $\mathrm{K}_{\mathrm{o}}$ & g.m $\mathrm{m}^{3}$ & $0,40-0,60$ & 0,50 \\
\hline \multicolumn{4}{|c|}{ Valores de $\theta$ (Coeficiente para correção devida à Temperatura) } \\
\hline$\mu_{\mathrm{nm}}$ & - & $1,06-1,123$ & 1,07 \\
\hline $\mathrm{K}_{\mathrm{N}}$ & - & $1,03-1,123$ & 1,053 \\
\hline Kdn & - & $1,03-1,08$ & 1,04 \\
\hline
\end{tabular}

Figura 16: Efeito da concentração de OD na velocidade de desnitrificação. Fonte: Adaptado de (METCALF \& EDDY, 2013).

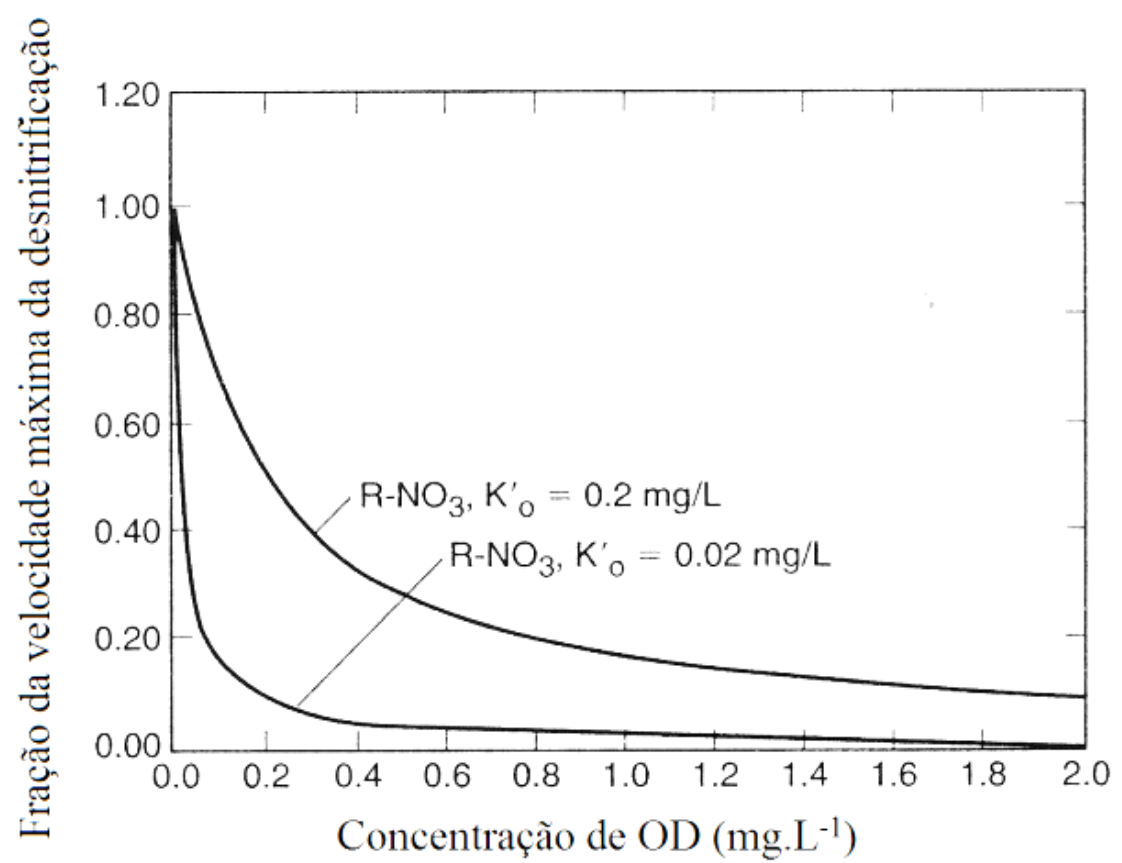

Observa-se que, para concentração de $O D$ de $0,20 \mathrm{mg} \cdot \mathrm{L}^{-1}$, a velocidade de desnitrificação pode ser $10 \%$ ou $50 \%$ da máxima. Em uma concentração de OD ao redor de $0,5 \mathrm{mg} \cdot \mathrm{L}^{-1}$ a velocidade de nitrificação se iguala à velocidade de desnitrificação. Holman e Wareham (2005) contestam a ideia de que a concentração 
ideal de OD seja de 0,5 mg. $\mathrm{L}^{-1}$ para ocorrência de NDS. Estudos realizados por Peng Zhang e Zhou Qi (2007) relatam que a taxa de nitrificação teve eficiência de 93\% sob uma concentração de OD entre 0,3-0,8 mg. $\mathrm{L}^{-1}$, sem afetar o desenvolvimento da NDS. No entanto, concentrações maiores que $1,0 \mathrm{mg}^{-L^{-1}}$ inibem a desnitrificação aeróbia. Os autores relataram que com a cultura de bactérias NDS estabelecida no reator, as desnitrificantes aeróbias podem continuar a reduzir nitrogênio em ambiente aeróbio por tempo limitado, desde que as concentrações de OD não excedam $1,0 \mathrm{mg} \cdot \mathrm{L}^{-1}$. Para sistemas com idade do lodo elevada (tempo de retenção hidráulica entre 18 e 30 horas), o tempo é suficiente para obtenção de eficiência elevada na redução de NO3, mesmo ocorrendo inibição devido à presença de OD em baixas concentrações. Conclusivamente, pode ser afirmado que um sistema de lodos ativados com aeração prolongada de fluxo contínuo pode ser adaptado para garantir também a desnitrificação do esgoto, implantando-se um sistema controlador da introdução de oxigênio dissolvido. A demanda deve ser suprida sem que ocorra ou deficit ou superavit excessivo, ou seja, mantendo-se a concentração de OD na faixa de 0,3 a $0,8 \mathrm{mg} \cdot \mathrm{L}^{-1}$, apesar da variação da carga orgânica afluente.

\subsubsection{Principais sistemas de remoção biológica de nitrogênio pelo processo de NDS}

Muitos estudos de remoção biológica de nitrogênio sob condições aeróbias com baixa concentração de oxigênio dissolvido foram realizados desenvolvendo o processo de NDS (COLLOVOGNARELLI e BERTANZA, 1999; HELMER et al., 1998; TURK e MAVINIC, 1989). Segundo os autores Collovognarelli e Bertanza, (1999) uma das vantagens do uso da NDS é a remoção da DQO e de nitrogênio na eficiência de processos tradicionais, com menor consumo de energia elétrica na aeração (cerca de $30-40 \%$ a menos), em comparação com um processo de pré-desnitrificação convencional. Outra vantagem é a produção de alcalinidade devido a desnitrificação conjunta e a produção de um efluente com baixa concentração de nitrogênio $(<3,0$ mgN.L-1) como obtidas em sistemas do tipo OrbalTM e Sym-BioTM (METCALF \& EDDY, 2013). Ainda, o processo elimina a necessidade de tanques para desnitrificação convencionais e, consequentemente, simplifica 0 projeto, 
economizando espaço e tempo. No entanto, uma limitação é a necessidade de um sistema de controle de aeração rigoroso e operação especializada, outra limitação é o tamanho dos tanques que necessitam de grandes volumes. Essas vantagens e limitações se aplicam a maioria dos sistemas que desenvolvem o processo de NDS (KELLER et al., 1997; SEN E DENTEL, 1998; ZHAO, H. W. et al., 1998; YOO et al., 1999; ZHAO, H. W., et al., 1999; METCALF \& EDDY, 2013). O processo de NDS foi aplicado a uma ampla gama de processos de tratamento biológico de águas residuais, tais como:

- Sistemas de biofilme aeróbio (HELMER et al., 1998);

- Sistemas de Membranas (CHANG e TSENG, 1999; WANG, et al., 2005; BAEK e PAGILLA, 2008);

- Sistema de remoção biológica de fósforo reforçada (ZENG et al., 2003);

- Sistemas de reatores de leito fluidizado (SEN e DENTEL, 1998; HALLINGSORENSEN e NIELSEN, 1996);

- Sistemas de reator em bateladas sequenciais - SBR (MUINCH et al., 1996; ZENG et al., 2003; CHIU, Y. C., et al., 2007; ASLAN, S., 2009);

- Sistemas de valos de oxidação (VON HUYSSTEEN, apudTCHOBANOGLOUS et al., 2004; GUO, J. H., 2010; TRIVEDI e HEINEN, 2000 apud METCALF \& EDDY, 2013);

- Sistemas de fluxo misto de lodos ativados (PENG ZHANG E ZHOU QI, 2007; THAURÉ et al., 2008; BUENO, 2011).

Dos sistemas citados acima, os de maior interesse para o presente estudo são discutidos abaixo.

\subsubsection{Valo de oxidação com baixa concentração de OD e monitoramento Sym- BioTM}

Estudos em valos de oxidação realizados por Treivedi e Heinen (2000) apud Metcalf \& Eddy (2013), mostram que é possível obter uma concentração de $\mathrm{NO}_{3}-\mathrm{N}$ e $\mathrm{NH}_{4}-\mathrm{N}$, menores que 3,0 mgN.L-1 e 1,0 mgN.L-1 no efluente final pelo processo de NDS. Para manter a concentração de OD abaixo de $0,5 \mathrm{mg} \cdot \mathrm{L}^{-1}$, o sistema de aeração pode ser controlado manualmente ou por um sistema automatizado. No estudo foram utilizados aeradores ao longo do canal do valo de oxidação como se observa na Figura 17, formando zonas anóxicas e aeróbias ao decorrer do sistema, permitindo um melhor controle do oxigênio. Além desse controle, os pesquisadores monitoraram as mudanças de NADH (enzima nicotinamida adenina dinucleotídeos) produzida pelas 
bactérias envolvidas na NDS no lodo ativado, através de uma sonda de medição, conhecido como processo de Sym-BioTM.

Figura 17: Representação esquemática de um sistema de lodo ativado de remoção de nitrogênio, modificado para operar com baixa concentração de OD.

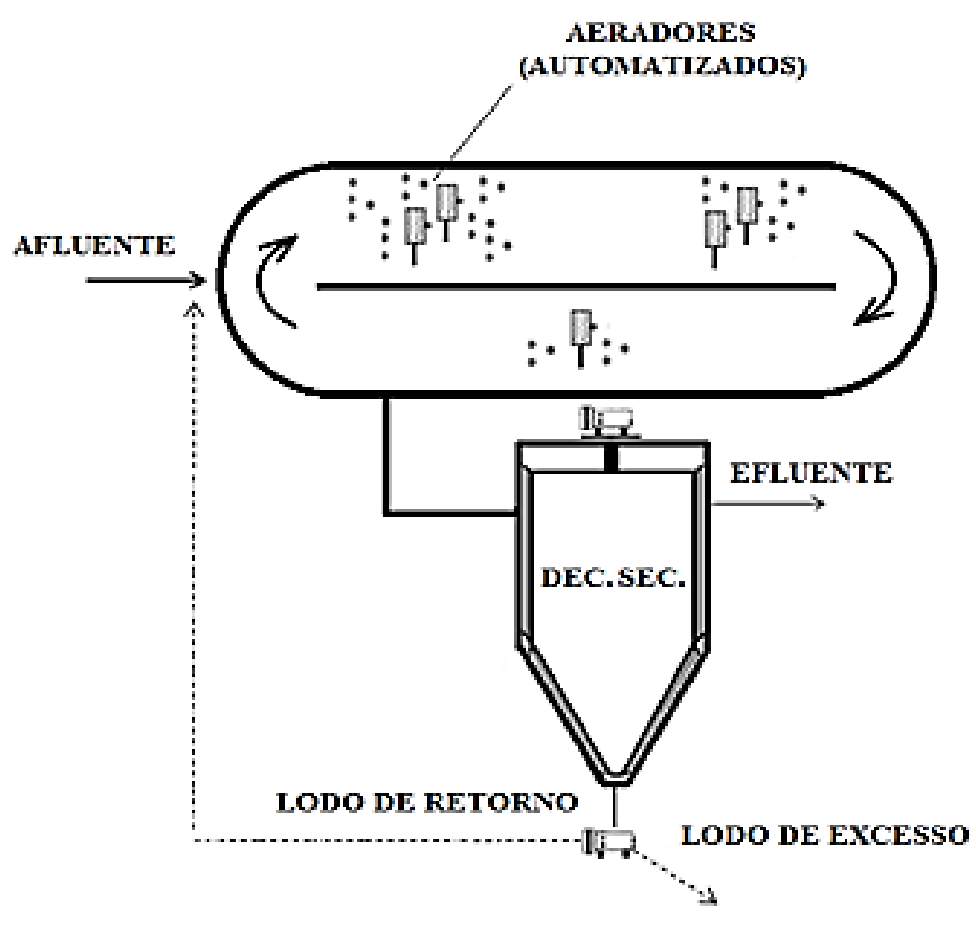

\subsubsection{Sistema de lodo ativado com diferentes concentrações de OD do tipo OrbalTM}

Outro arranjo do sistema de lodo ativado para remoção de nitrogênio pelo processo de NDS, é o sistema Orbal ${ }^{T M}$ (METCALF \& EDDY, 2013), onde o sistema é operado em canais em série, com diferentes concentrações de OD, conforme se observa na Figura 18. Sendo o primeiro canal operado com OD praticamente zero $\left(<0,3 \mathrm{mg} \cdot \mathrm{L}^{-1}\right)$, o segundo canal de 0,5 a 1,5 mg. $\mathrm{L}^{-1}$, e o terceiro canal com alta concentração de OD na faixa de 2,0 a 3,0 mg. $\mathrm{L}^{-1}$. O primeiro canal recebe o esgoto afluente e o lodo de retorno (geralmente cerca de $50 \%$ do volume total). Os volumes do segundo e terceiro canal, são cerca de 1/3 e 1/6 do volume total, respectivamente. O reciclo de licor misto interno, para os canais externos permite a desnitrificação de nitratos resultantes da nitrificação nos canais internos. Variações do processo podem operar com ou sem reciclo interno do terceiro para o primeiro canal. O sistema opera com um TRS de 10 a 30 dias, com uma concentração de SSV no licor misto na faixa de 2,0 a 4,0 g.L $\mathrm{L}^{-1}$. O 
TDH de operação total, normalmente fica entre 10 a 20 horas, sendo de 6 a 10 horas na zona anóxica e de 3 a 6 horas na zona aeróbia. A vantagem desse sistema é a possível economia com o gasto de energia elétrica para aeração, a produção de alcalinidade devido a desnitrificação conjunta, a produção de um efluente com baixa concentração de nitrogênio $\left(<3,0 \mathrm{mgN} \cdot \mathrm{L}^{-1}\right)$, facilidade da incorporação e construção dos sistemas. No entanto como limitações, é necessário um sistema de controle rigoroso e operação especializada, outra desvantagem é o tamanho dos tanques que necessitam de grandes volumes. Essas vantagens e limitações se aplicam ao sistema do tipo Sym-BioTM e aos principais processos de NDS.

Figura 18: Representação esquemática de um sistema de lodo ativado tipo OrbalTM de remoção de nitrogênio, modificado para operar com baixa concentração de $O D$ promovendo o processo de NDS. Fonte: Adaptado de (METCALF \& EDDY, 2013).

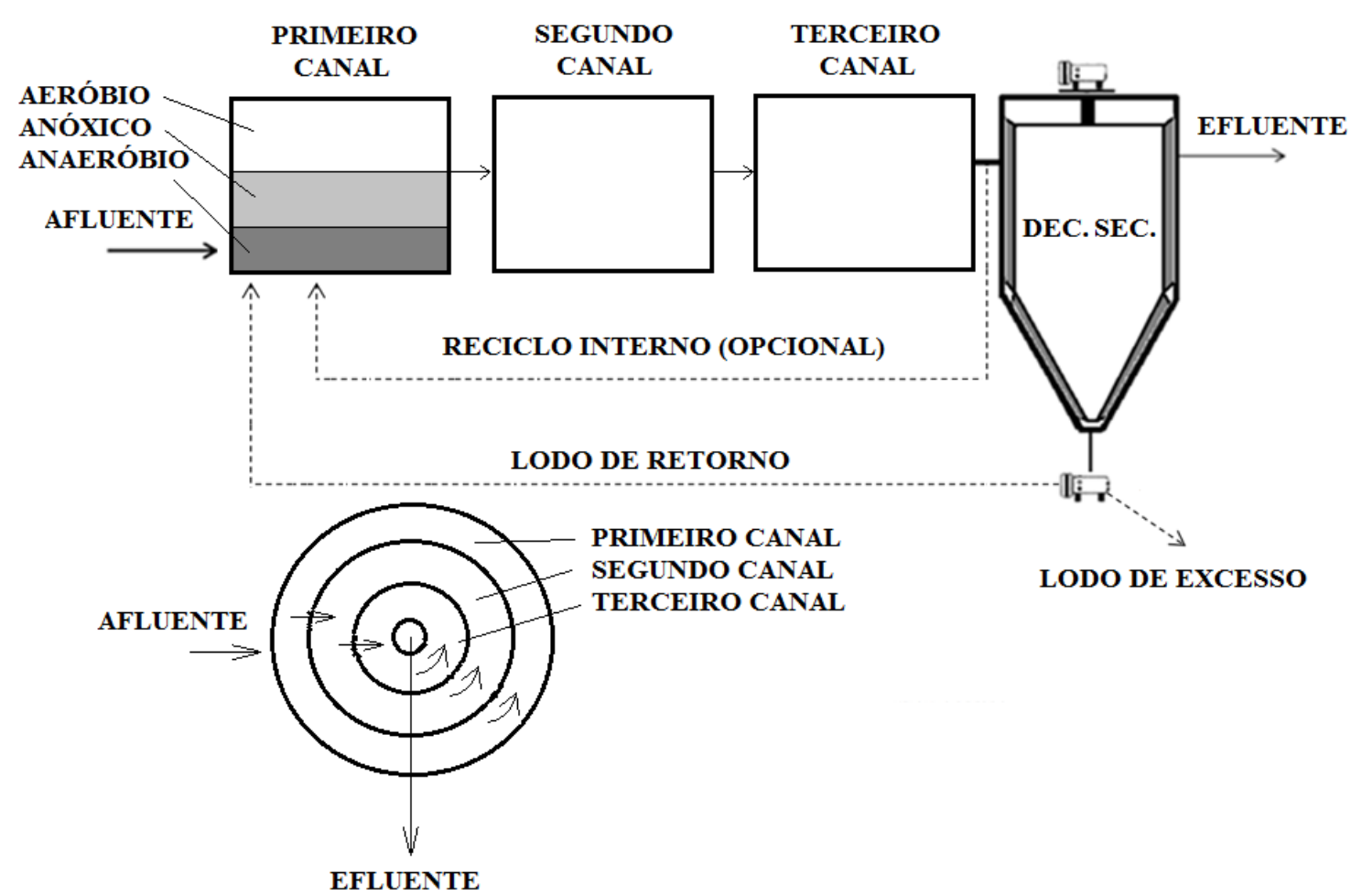




\subsubsection{Sistema de lodos ativados por aeração prolongada de fluxo contínuo}

O sistema de lodos ativados por aeração prolongada, operam com uma idade de lodo elevada entre 18 a 30 dias e com tempo de TDH em torno de 16 a 24 horas. Recomenda-se esse tipo de processo para que se tenha a promoção satisfatória da nitrificação, visto que as bactérias nitrificantes são de crescimento lento em comparação com as bactérias heterotróficas que oxidam a matéria orgânica. Quando o sistema recebe a mesma carga de DBO de esgoto bruto que o sistema convencional, haverá menor disponibilidade de alimento para as bactérias, ou seja, a relação alimento / microrganismos $(\mathrm{A} / \mathrm{M})$ é menor que no processo convencional e a quantidade de biomassa (KgSSVTA) maior. O volume do tanque de aeração é também mais elevado. Portanto, há menos matéria orgânica por unidade de biomassa no tanque de aeração. Em decorrência as bactérias, para sobreviver, passam a utilizar de forma mais intensa nos seus processos metabólicos a própria matéria orgânica biodegradável componente das suas células (VON SPERLING, 2002). Esta matéria orgânica celular é convertida em gás carbônico e água através da respiração. Isto corresponde a uma estabilização da biomassa, ocorrendo no próprio tanque de aeração. No entanto para a estabilização do lodo no tanque de aeração há um consumo adicional de oxigênio (respiração endógena) que é significativo e pode ser maior que o consumo para metabolizar o material orgânico afluente (respiração exógena). Deste modo, os sistemas de aeração prolongada usualmente não possuem decantadores primários, para evitar a necessidade de se estabilizar o lodo primário. Com isto, obtém-se uma grande simplificação no fluxograma do processo, sendo o sistema composto de basicamente de tanque de aeração e decantador secundário. $A$ consequência desta simplificação do sistema é o gasto elevado com energia para aeração quando comparado com outros sistemas, já que o lodo é estabilizado aerobiamente no tanque de aeração. Estudos realizados por Alem Sobrinho e Kato (1999) e Alem Sobrinho e Jordão (2001) comparam o gasto com energia elétrica na aeração para os principais sistemas de lodo ativado e suas principais características no tratamento de esgotos domésticos, como se observa na Tabela 3. Como veremos posteriormente, uma das maneiras de se reduzir o gasto com energia elétrica em um sistema de aeração prolongada, sem reduzir a eficiência dos processos, é adaptando o sistema para operar em condições controladas com baixas concentrações de 
oxigênio dissolvido, desenvolvendo o processo de nitrificação e desnitrificação simultânea, tema desse estudo. Que além da economia com o gasto de energia elétrica na aeração nos traz o benefício da desnitrificação no sistema.

Tabela 3: Principais características dos sistemas de lodos ativados utilizados para o tratamento de esgotos domésticos

\begin{tabular}{|c|c|c|c|c|}
\hline \multirow[b]{2}{*}{ Item geral } & \multirow[b]{2}{*}{ Item específico } & \multicolumn{3}{|c|}{ Modalidade } \\
\hline & & Convencional & $\begin{array}{c}\text { Aeração } \\
\text { prolongada }\end{array}$ & $\begin{array}{l}\text { UASB-lodos } \\
\text { ativados }\end{array}$ \\
\hline Idade do lodo & Idade do lodo $\left(\mathrm{d}^{-1}\right)$ & $4-10$ & $18-30$ & $6-10$ \\
\hline Relação A/M & $\begin{array}{c}\text { Relação A/M } \\
\left(\mathrm{kgDBO} \mathrm{KgSSVTA}^{-1} \mathrm{~d}^{-1}\right)\end{array}$ & 0,25 a 0,50 & 0,07 a 0,15 & 0,25 a 0,40 \\
\hline \multirow{7}{*}{$\begin{array}{l}\text { Eficiência de } \\
\text { remoção }\end{array}$} & $\mathrm{DBO}(\%)$ & $85-95$ & $93-98$ & $85-95$ \\
\hline & DQO (\%) & $85-90$ & $90-95$ & $83-90$ \\
\hline & Sólidos em suspensão (\%) & $85-95$ & $85-95$ & $85-95$ \\
\hline & Amônia (\%) & $85-95$ & $90-95$ & $75-90$ \\
\hline & (1) Nitrogênio (\%) & $25-30$ & $15-25$ & $15-25$ \\
\hline & (1) Fósforo (\%) & $25-30$ & $10-20$ & $10-20$ \\
\hline & Coliformes (\%) & $60-90$ & $70-95$ & $70-95$ \\
\hline \multirow{2}{*}{ Massa de lodo } & $\begin{array}{c}\text { A ser tratado } \\
\left(\mathrm{L}^{-1} \text { lodo.hab.ano }\right)\end{array}$ & $60-80$ & $40-45$ & $20-30$ \\
\hline & $\begin{array}{c}\text { A ser disposto } \\
\left(\mathrm{L}^{-1} \text { lodo.hab.ano }\right)\end{array}$ & $30-45$ & $40-45$ & $20-30$ \\
\hline \multirow{2}{*}{$\begin{array}{l}\text { (2) Volume de } \\
\text { lodo }\end{array}$} & $\begin{array}{c}\text { A ser tratado } \\
\left(\mathrm{g}^{-1} \text { ST.hab.dia }\right)\end{array}$ & $3,5-8,0$ & $3,5-5,5$ & $0,5-1,0$ \\
\hline & $\begin{array}{c}\text { A ser disposto } \\
\left(\mathrm{g}^{-1} \text { ST.hab.dia }\right)\end{array}$ & $0,10-0,25$ & $0,10-0,25$ & $0,05-0,15$ \\
\hline \multirow[b]{2}{*}{ (3) Energia } & Potência instalada (w.hab) & $2,5-4,5$ & $3,5-5,5$ & $1,8-3,5$ \\
\hline & $\begin{array}{c}\text { Consumo energético } \\
\text { (kwh.hab.ano) }\end{array}$ & $18-26$ & $20-35$ & $14-20$ \\
\hline
\end{tabular}

Fonte: Adaptada parcialmente de (ALEM SOBRINHO e KATO, 1999; ALEM SOBRINHO e JORDÃO, 2001).

Considerações:

(1): Pode-se alcançar eficiências maiores na remoção de $N$ (especialmente no lodo ativado convencional e na aeração prolongada) e de $\mathrm{P}$ (especialmente no lodo ativado convencional) através de etapas específicas (desnitrificação e desfosfatação). A modalidade UASB - lodo ativado não é eficiente na remoção biológica de $\mathrm{N}$ e P;

(2): O volume de lodo é função da concentração de sólidos totais (ST), a qual depende dos processos utilizados no tratamento da Fase líquida e da Fase sólida. A faixa superior do volume per capita de lodo a ser disposto está associada ao desaguamento por centrífuga e filtro de correia (menores concentrações de ST no lodo desidratado), ao passo que a faixa inferior está associada a leitos de secagem ou filtros-prensa (maiores concentrações de ST);

(3): A potência instalada deve ser suficiente para suprir a demanda de $\mathrm{O}_{2}$ em cargas de pico. O consumo energético pressupõe certo controle do fornecimento do $\mathrm{O}_{2}$, reduzindo-o em momentos de menor demanda. 


\subsubsection{Otimização do processo de lodos ativados com aeração prolongada para o desenvolvimento da NDS}

Os autores Pen Zhang e Zhou Qi, 2007 realizaram pesquisas em um sistema piloto de lodo ativado por aeração prolongada alimentado em fluxo contínuo com esgoto sintético. Os autores operaram o sistema com TRS elevados, na faixa de 60, 45 e 30 dias com razões de A/M de 0,05-0,30 gDQO.gSSVLM.d ${ }^{-1}$. A concentração de OD no tanque de aeração foi mantida na faixa de $0,3-0,8 \mathrm{mg} \cdot \mathrm{L}^{-1}$. O estudo mostra a ocorrência do processo de NDS em todas as condições. Porém, na condição onde o TRS de 45 dias com razão de A/M de 0,1 gDQO.gSSVLM.d ${ }^{-1}$ e uma relação $\mathrm{C} / \mathrm{N}$ de 10, o sistema apresentou uma melhor eficiência, chegando a $93 \%$ na nitrificação, e acima de $60 \%$ na remoção de nitrogênio total. Estudos com baixa concentração de OD (0,5 mg. $\left.\mathrm{L}^{-1}\right)$ conduzidos por Thauré et al. (2008) em uma ETE localizada próxima de Toulouse com capacidade de $1.000 \mathrm{~m} 3 / \mathrm{d}(11,6 \mathrm{~L} / \mathrm{s})$, obteve uma redução significativa de energia elétrica na aeração, na ordem de 10 a 50\%. A ETE foi operada com TRS de 30 a 40 dias, com razão A/M de 0,03 a 0,05 kgDQO.kgSSVLM.d ${ }^{-1}$ e concentração de SSV no licor misto de 3 a $4 \mathrm{~g} \cdot \mathrm{L}^{-1}$. Os autores ainda relatam que não foi observado o aparecimento de bactérias filamentosas no licor misto e a ocorrência do processo de NDS durante o controle de OD em baixas concentrações. Com base na revisão apresentada, nota-se, que é possível obter o processo de NDS com eficiência elevada em um arranjo praticamente simples, que é o caso do sistema escolhido nesta pesquisa.

\subsection{Modelo cinético da remoção dos compostos orgânicos no processo de lodos ativados}

\subsubsection{Cinética do processo de remoção de material orgânico}

Esclarece-se que a terminologia e o modelo cinético utilizado nesta pesquisa para a determinação da cinética do processo de remoção de material orgânico e do material nitrogenado é o modelo simplificado da teoria de lodo ativado, descrito por Van Haandel e Marais (1999). 


\subsubsection{Balanço de massa de material orgânico}

Em um sistema de lodo ativado, uma fração da massa de material orgânico afluente (mSta) não é removida da Fase líquida e deixa o sistema junto com o efluente (mSte); outra é transformada em lodo orgânico e deixa o sistema como lodo de excesso (mSxv); e a fração restante é oxidada para produtos inorgânicos gasosos (mSo). As frações de material orgânico que deixam o sistema na forma de lodo, oxidada e no efluente, em termos de DQO, permitem fazer o balanço de massa do material orgânico (Bo) (Equação 40). De acordo com Van Haandel e Marais (1999), quando o balanço fecha, ou seja, quando Bo = 1 o sistema é dito operar sob condições de carga orgânica constante e que os erros analíticos normalmente cometidos não são significativos.

Eq. (40)

Bo $=($ MSte + MSxv + MSo $) / M S t a=1$

Sendo:

MSta: fluxo de DQO afluente (mgDQO.d-1)

MSte: fluxo de DQO efluente (mgDQO.d-1)

MSxv: fluxo de DQO que sai no lodo de excesso $\left(\mathrm{mgDQO}^{-1} \mathrm{~d}^{-1}\right)$

MSo: fluxo de DQO oxidada (mgDQO.d-1)

\subsubsection{Fatores cinéticos da utilização de material orgânico}

O principal fator a ser considerado, quando se pretende determinar a cinética da utilização do material orgânico, é a taxa de utilização deste material. Essa taxa corresponde à velocidade com que os processos oxidativos e de síntese ocorrem em sistemas de lodo ativado. A taxa de crescimento das bactérias heterotróficas é proporcional à taxa de utilização de substrato. A concentração do substrato influencia a taxa de utilização desse substrato. Assim, o crescimento bacteriano ocorre em função da disponibilidade de material orgânico. Quando há pouca disponibilidade de substrato, a taxa de crescimento é proporcionalmente reduzida e quando não se tem 
limitação de substrato essa taxa de crescimento é máxima (VAN HAANDEL E MARAIS,1999). A Equação 41 expressa a relação entre a taxa específica máxima de crescimento e a disponibilidade desse substrato.

$\mu_{\mathrm{m}}=\mu_{\operatorname{máx}}{ }^{*}[\mathrm{~S} /(\mathrm{S}+\mathrm{Ks})]$

Sendo:

$\mu_{\mathrm{m}}$ : taxa específica de crescimento $\left(\mathrm{d}^{-1}\right)$;

$\mu$ máx: taxa específica máxima de crescimento $\left(\mathrm{d}^{-1}\right)$;

Ks: constante de meia saturação;

S: concentração de substrato $\left(\mathrm{mg} \cdot \mathrm{L}^{-1}\right)$.

Quando a quantidade de substrato é máxima, de modo que não limita o metabolismo bacteriano, $S$ > $\mathrm{Ks}$, pode-se considerar que $\mu \mathrm{m}$ é igual ao valor de $\mu$ máx, sendo $\mu$ máx determinado conforme a Equação 42 (VAN HAANDEL E MARAIS,1999).

$\mu_{\text {máx }}=\left(Y^{*} r_{\text {máx }}\right) / X a$

Sendo:

$\mathrm{X}_{\mathrm{a}}$ : concentração das bactérias heterotróficas $\left(\mathrm{mg}^{\mathrm{L}} \mathrm{L}^{-1}\right)$;

Y: coeficiente de rendimento das bactérias heterotróficas $\left(0,45 \mathrm{mgXa}^{*} \mathrm{mgDQO}^{-1}\right)$ (VAN HAANDEL E MARAIS,1999);

rmáx: taxa de utilização máxima do material carbonáceo (mgDQO.mgXa-1.d-1 ${ }^{-1}$, determinada, por exemplo, através de testes respirométricos.

A Equação 43 apresenta uma forma simples de determinar a taxa máxima de utilização do material carbonáceo.

Eq. (43) 
$r_{\text {máx }}=3^{*} \mathrm{TCO}_{\mathrm{exo}} / \mathrm{Xa}$

Sendo:

rmáx: taxa de utilização máxima do material carbonáceo $\left(\mathrm{mgDQO}^{*} \mathrm{mg} \mathrm{X}_{\mathrm{a}}-1^{*} \mathrm{~d}^{-1}\right)$;

TCO exo: taxa de consumo de oxigênio exógena (a DQO oxidada é equivalente a TCOexo $\times 3$, visto que 1/3 do material biodegradável adicionado é oxidado.

Observando as Equações 42 e 43, percebe-se que, tendo-se determinado a TCOexo (através dos testes respirométricos), para se calcular rmáx (Equação 43) e $\mu$ máx (Equação 42) é necessária a determinação da concentração de lodo ativo $X_{a}$ (Equação 44). É importante destacar que nem todo material volátil é biomassa ativa. $O$ valor desse parâmetro pode ser estabelecido por dois critérios independentes segundo Marais e Ekama, (1976):

(1) a teoria de lodo ativado mostra que a concentração de lodo ativo se expressa como:

$\mathrm{Xa}=\mathrm{Y}{ }^{*} \mathrm{Rh}{ }^{*} \mathrm{Sta} /\left(1+\mathrm{bh}{ }^{*} \mathrm{Rs}\right){ }^{*} \mathrm{Rh}$

Sendo:

$R_{h}$ : tempo de permanência do líquido $\left(d^{-1}\right)$;

Sta: DQO do afluente $\left(\mathrm{mg} \cdot \mathrm{L}^{-1}\right)$;

$b_{h}$ : constante de decaimento de lodo ativo $\left(d^{-1}\right)$;

Rs: idade de lodo $\left(\mathrm{d}^{-1}\right)$;

(2) a partir da TCO endógena, determinada na ausência de material extracelular, também se pode determinar o valor de Xa:

A Equação 45 apresenta mais uma maneira de cálculo utilizado para determinar a concentração das bactérias heterotróficas ativas no sistema. Para melhor estimativa de Xa, usa-se a média dos resultados obtidos pelos dois métodos.

$\mathrm{Xa}=\mathrm{TCOend} /\left[\mathrm{fcr}{ }^{*}(1-\mathrm{f}){ }^{*} \mathrm{bh}\right]$

Sendo: 
bh: constante de decaimento para as bactérias heterotróficas $(0,24$ * 1,04(t-20), onde t é a temperatura de operação) (VAN HAANDEL E MARAIS,1999);

$\mathrm{X}_{\mathrm{a}}$ : concentração das bactérias heterotróficas $\left(\mathrm{mgSSV}^{-1} \cdot \mathrm{L}^{-1}\right)$;

TCOend: taxa de consumo de oxigênio endógena $\left(\mathrm{mgO} 2 \cdot \mathrm{L}^{-1} \cdot \mathrm{h}^{-1}\right)$;

$\mathrm{f}_{\mathrm{cv}}$ : fator de conversão de DQO para material ativo heterotrófico $\left(1,5 \mathrm{mgDQO} . \mathrm{mgSSV}\right.$ - $^{-}$ 1) (VAN HAANDEL E MARAIS,1999);

f: fração não biodegradável após total decaimento do lodo = 0,2 (resíduo endógeno).

$\mathrm{Na}$ Tabela 4 se observam os valores típicos das constantes de crescimento específico máximo das bactérias heterotróficas $\left(\mu_{\mathrm{m}}\right)$, as taxas de utilização de material orgânico das bactérias heterotróficas ( $r$ máx) e as constantes de meia saturação de Monod.

Tabela 4: Valores de referência das constantes cinéticas de utilização de material orgânico

\begin{tabular}{|c|c|c|}
\hline \multicolumn{3}{|c|}{ Fatores cinéticos de utilização de material orgânico } \\
\hline Constante & Valores & Referências \\
\hline \multirow{3}{*}{$\mu_{m}\left(d^{-1}\right)$} & 3,7 & $\begin{array}{l}\text { LAWRENCE et al., (1970) apud BAILEY E OLLIS, } \\
\text { (1977). }\end{array}$ \\
\hline & $2,4-7,2$ & HORAN (1990). \\
\hline & $1,5-5,0$ & METCALF \& EDDY (2013). \\
\hline \multirow{2}{*}{$\begin{array}{c}r_{\text {máx }} \\
\left(m g D Q O . L^{-1}\right)\end{array}$} & 20 & DOLD et al., (1980) apud VAN HAANDEL (2006). \\
\hline & $5,0-40,0$ & METCALF \& EDDY (2013). \\
\hline \multirow{2}{*}{$\begin{array}{c}\mathrm{K}_{\mathrm{s}} \\
\left(\mathrm{mgDQO} \cdot \mathrm{L}^{-1}\right)\end{array}$} & 5 & DOLD et al., (1980) apud VAN HAANDEL (2006). \\
\hline & $1,0-5,0$ & METCALF \& EDDY (2013). \\
\hline
\end{tabular}

Fonte: adaptado de (VAN HAANDEL e MARAIS, 1999; METCALF \& EDDY, 2013).

\subsection{Modelo cinético da remoção dos compostos nitrogenados no processo de lodos ativados}

A nitrificação se desenvolve em dois passos sequenciais, mas geralmente se considera somente o primeiro passo (oxidação de amônia para nitrito), que tem maior importância para a cinética do processo. Quando à população das bactérias nitrificantes estão bem estabelecidas, o segundo passo, a oxidação de nitrito para nitrato, desenvolve-se tão rapidamente, que, para efeitos práticos, pode ser considerada instantânea. Downing et al. (1964) foram os primeiros a mostrar que o 
crescimento de Nitrosomonas na oxidação de amônia para nitrito pode ser descrito adequadamente com auxílio da equação de Monod:

$(d X n / d t)=(d X n / d t) c+(d X n / d t) d$

Com: $(d X n / d t) c=\mu X n=\mu m$ Xn.Na $/(N a+K n)$ e $(d X n / d t) d=-b n X n$

Onde:

Xn: concentração de Nitrosomonas (mgSVS.L-1 ${ }^{-1}$;

(dXn/dt): taxa de variação da concentração de Nitrosomonas (mgSVS.L $\left.{ }^{-1} \cdot d^{-1}\right) /$ taxa de crescimento líquido;

$(\mathrm{dXn} / \mathrm{dt}) \mathrm{c}$ : taxa de crescimento de Nitrosomonas $\left(\mathrm{mgSVS} . \mathrm{L}^{-1} \cdot \mathrm{d}^{-1}\right) /$ taxa de crescimento bruto;

$(\mathrm{dXn} / \mathrm{dt}) \mathrm{d}$ : taxa de decaimento de Nitrosomonas (mgSVS. $\left.\mathrm{L}^{-1} \cdot \mathrm{d}^{-1}\right)$;

$\mu$ : taxa específica de crescimento de Nitrosomonas $\left(\mathrm{d}^{-1}\right)$;

$\mu_{\mathrm{m}}$ : taxa específica máxima de crescimento de Nitrosomonas $\left(\mathrm{d}^{-1}\right)$;

$b_{n}$ : constante de decaimento de Nitrosomonas $\left(\mathrm{d}^{-1}\right)$;

$\mathrm{k}_{\mathrm{n}}$ : constante de meia saturação de Monod $\left(\mathrm{mgN}^{-1} \mathrm{~L}^{-1}\right)$.

$\mathrm{Na}$ equação de MONOD, a constante $\mu$ representa o crescimento bruto dos microrganismos por unidade de tempo. Assim, um valor $\mu=0,6 \mathrm{~d}^{-1}$ significa que a massa de microrganismos sintetizada tem uma taxa de $60 \%$ ao dia. Como a taxa de crescimento é exponencial, quando não há limitação de substrato, o crescimento em um dia seria $\mathrm{N} 1 / \mathrm{N} 0=\exp \left(0,6^{*} 1\right)=1,81$, ou seja, a massa pode aumentar em um dia até um fator 1,81 ou $81 \%$. A equação 46 mostra que o valor de $\mu$ depende da concentração do substrato $(\mathrm{Na})$, sendo que para uma concentração alta (saturação) se atinge o valor $\mu \mathrm{m}$. A constante Kn é igual à concentração do substrato quando $\mu=$ $1 / 2 \mu \mathrm{m}$ e por esta razão é chamada de constante de meia saturação. Para calcular a concentração residual de amônia em um sistema de lodo ativado completamente misturado e operado sob condições estacionárias, usa a equação básica de DOWNING et al. (1964). Nessas condições, não há variação de massa de Nitrosomonas: a taxa de crescimento líquida (que é igual à taxa de crescimento bruto 
menos a taxa de decaimento de Nitrosomonas) é igual à taxa de descarga de lodo de excesso (supõe-se que o lodo seja retirado continuamente do reator biológico). Portanto:

$((d X n / d t)=0=(d X n / d t) c+(d X n / d t) d+(d X n / d t) e$

A taxa de variação da concentração de Nitrosomonas devido à descarga de lodo (dXn/dt)e, pode ser expressa como:

$(\mathrm{dXn} / \mathrm{dt}) \mathrm{e}=-\mathrm{Xn} / \mathrm{Rs}$

Usando-se as Equações 46 e 48 na Equação 47, tem-se:

$(\mathrm{dXn} / \mathrm{dt})=0=\mu \mathrm{mXnNa} /(\mathrm{Na}+\mathrm{Kn})-\mathrm{bnXn}-\mathrm{Xn} / \mathrm{Rs}=\mu \mathrm{m} . \mathrm{Na} /(\mathrm{Na}+\mathrm{Kn})-\mathrm{bn}-1 / \mathrm{Rs}$

Ou, rearranjando:

Eq. (50)

$\mathrm{Na}=\mathrm{Kn}(\mathrm{bn}+1 / \mathrm{Rs}) /[\mu \mathrm{m}-(\mathrm{bn}+1 / \mathrm{Rs})]$

A Equação 50 dá o valor da concentração de amônia no licor misto, em um sistema de lodo ativado completamente misturado, e, portanto, também no efluente. Essa concentração residual, que é indicativa para a eficiência da nitrificação, depende das três constantes cinéticas $\mu \mathrm{m}, \mathrm{K}_{n}$ e $\mathrm{b}_{\mathrm{n}}$ e de uma variável do processo: a idade de lodo Rs. É notável que a concentração residual não dependa da sua concentração inicial. Naturalmente, a concentração residual de amônia nunca pode ser superior à concentração no afluente de amônia disponível para nitrificação. Esta condição define uma idade de lodo mínima expressa como: 
Eq. (51)

$N_{a} \ll N_{p}=K_{n}\left(b_{n}+1 / R_{s n}\right) /\left(\mu_{m}-b_{n}-1 / R_{s n}\right)$

ou

$R_{s n}=\left(1+K_{n} / N_{p}\right) /\left[\mu_{m}-b_{n}\left(1+K_{n} / N_{p}\right)\right]$

Eq. (52)

$R_{s n}=1 /\left(\mu_{m}-b_{n}\right)$

Onde:

$\mathrm{N}_{\mathrm{p}}$ : concentração de amônia disponível para nitrificação (mg.L-1 $)$.

Para águas residuárias municipais a concentração de amônia disponível para nitrificação é sempre muito maior que $K_{n}$. Nesse caso, a razão $K_{n} / N_{p}$ é $\ll 1$, e a Equação 51 se simplifica para:

Eq. (53)

$R_{s n}=1 /\left(\mu_{m}-b_{n}\right)$

A Equação 52 expressa que, até uma idade de lodo $R_{s n}=1 /\left(\mu_{m}-b_{n}\right)$, a nitrificação não se desenvolve porque a taxa de retirada de Nitrosomonas é maior que a taxa máxima de crescimento líquido. Para idades de lodo superiores à mínima $R_{s n} a$ nitrificação desenvolver-se-á e a sua eficiência dependerá da idade de lodo e dos valores das constantes $K_{n}, \mu_{m}$ e $b_{n}$. Após o trabalho pioneiro de Downing et al. (1964), vários pesquisadores realizaram investigações experimentais para determinar as constantes cinéticas de nitrificação no sistema de lodo ativado. Van Haandel e Marais (1999), analisando a influência de diferentes valores das constantes de nitrificação sobre a eficiência de oxidação de amônia em sistemas de lodo ativado, concluíram três aspectos: $O$ primeiro é que a faixa de variação das constantes de decaimento $\mathrm{e}$ de meia saturação $\left(0<b_{n}<0,1 \mathrm{~d}^{-1}\right.$ e $\left.0<K_{n}<2 \mathrm{mg} \cdot \mathrm{L}^{-1}\right)$ tem, relativamente, pouca importância sobre a nitrificação. Para efeitos práticos podem ser considerados $b_{n}=$ $0,04(1,123)^{(t-20)}$ e $K_{n}=1,0(1,123)^{(t-20)}$. Nas Tabelas 5 e 6 se observam os valores típicos das constantes de decaimento $\left(b_{n}\right)$ e das constantes de meia saturação de amônia na equação de Monod para o crescimento de Nitrosomonas $\left(K_{n}\right)$. 
Tabela 5: Valores de referência das constantes de decaimento de Nitrosomonas (bn)

\begin{tabular}{cccc}
\hline & \multicolumn{3}{c}{ Constante de decaimento de Nitrosomonas $\left(\mathbf{b}_{\mathbf{n}}\right)$} \\
\hline $\mathbf{b}_{\mathbf{n t}}\left(\mathbf{d}^{\mathbf{- 1}}\right)$ & $\mathbf{T}\left({ }^{\circ} \mathbf{C}\right)$ & $\mathbf{b}_{\mathbf{n} 20}\left(\mathbf{d}^{-1}\right)$ & Referência \\
\hline 0,0 & 20 & 0,0 & DOWNING et al, (1964) \\
\hline 0,0 & 15 & 0,0 & DOWNING et al, (1964) \\
\hline 0,0 & 10 & 0,0 & GUJER $(1979)$ \\
\hline 0,04 & 20 & 0,04 & EKAMA \& MARAIS (1976) \\
\hline 0,12 & 29 & 0,09 & LIJKELMA (1973) \\
\hline 0,12 & 23 & 0,11 & PODUSKA \& ANDREWS (1974) \\
\hline- & 20 & $0,05-0,15$ & METCALF \& EDDY (2013)
\end{tabular}

Fonte: adaptado de (VAN HAANDEL e MARAIS, 1999) e (METCALF \& EDDY, 2013).

Tabela 6: Valores das constantes de meia saturação de amônia para as Nitrosomonas (Kn)

\begin{tabular}{cccc}
\hline \multicolumn{5}{c}{ Constante de meia saturação de amônia para o crescimento de } \\
Nitrosomonas $\left(\mathbf{K}_{\mathbf{n}}\right)$
\end{tabular}

Fonte: adaptado de (VAN HAANDEL e MARAIS, 1999) e (METCALF \& EDDY, 2013).

Em segundo lugar, em contraste, a influência do valor da constante de crescimento máximo de nitrificantes $\mu_{\mathrm{m}}$ sobre a idade de lodo mínima de nitrificação é muito grande e idealmente deve ser determinada antes que se faça o projeto do sistema de tratamento. Geralmente, porém, não se dispõe da água residuária quando se faz o sistema de tratamento e, neste caso, pode se adotar como valor estimado $\mu_{\mathrm{m}} 20=0,4$ $\mathrm{d}^{-1}$. Por fim, tendo em vista que a idade mínima de lodo depende, principalmente, do valor de $\mu_{\mathrm{m}}$, torna-se necessário analisar por que razões há uma variação tão grande nos valores dessa constante. Os valores que influenciam o valor $\mu \mathrm{m}$ podem ser divididos em duas categorias: fatores relacionados com a origem ou a natureza das águas residuárias e fatores que se referem às condições operacionais prevalecentes 
no sistema de tratamento. Referente às condições operacionais do sistema de lodo ativado, pode-se distinguir os seguintes fatores que influenciam o valor de $\mu_{\mathrm{m}}$ : temperatura; concentração de oxigênio dissolvido; $\mathrm{pH}$ do licor misto; nitrificação em sistemas com zonas não aeradas. Na Tabela 7, podem-se observar os valores típicos das constantes de crescimento específico máximo de Nitrosomonas $\left(\mu_{\mathrm{m}}\right)$.

Tabela 7: Valores das constantes de crescimento específico máximo de Nitrosomonas $(\mu \mathrm{m})$.

\begin{tabular}{cccc}
\hline \multicolumn{4}{c}{ Constantes de crescimento específico máximo de Nitrosomonas $\left(\boldsymbol{\mu}_{\mathrm{m}}\right)$} \\
\hline $\boldsymbol{\mu}_{\mathrm{mT}}\left(\mathbf{d}^{-1}\right)$ & $\mathbf{T}\left({ }^{\circ} \mathbf{C}\right)$ & $\boldsymbol{\mu}_{\mathbf{m} 20}\left(\mathbf{d}^{-1}\right)$ & Referências \\
\hline 0,33 & 15 & 0,66 & BARNARD $(1991)$ \\
\hline 0,47 & 15 & 0,45 & KAYSER $(1991)$ \\
\hline 0,45 & 15 & 0,73 & ECKENFELDER $(1992)$ \\
\hline 0,53 & 25 & 0,26 & SUTTON et al, $(1979)$ \\
\hline $0,40-0,50$ & 14 & $0,80-1,00$ & GUJER $(1977)$ \\
\hline $0,33-0,65$ & 20 & $0,33-0,65$ & EKAMA \& MARAIS $(1976)$ \\
\hline $1,08-1,44$ & 23 & $0,75-1,02$ & PODUSKA \& ANDREWS (1974) \\
\hline 0,57 & 16 & 0,76 & GUJER \& JENKINS $(1975)$ \\
\hline $0,34-0,40$ & 12 & $0,86-1,01$ & GUJER \& JENKINS (1975) \\
\hline 0,50 & 20 & 0,50 & LAWRENCE \& BROWN $(1973)$ \\
\hline 0,94 & 29 & 0,33 & LIJKELMA (1973) \\
\hline 0,33 & 20 & 0,33 & DOWNING et al, (1964) \\
\hline- & - & $0,20-0,90$ & METCALF \& EDDY $(2013)$ \\
\hline
\end{tabular}

Fonte: adaptado de (VAN HAANDEL e MARAIS, 1999; METCALF \& EDDY, 2013). 


\section{MATERIAIS E MÉTODOS}

\subsection{Localização da Estação de Tratamento de Esgoto da SABESP ETE - LIMOEIRO}

O estudo foi desenvolvido na Estação de Tratamento de Esgoto (ETE - LIMOEIRO) sob concessão da Companhia de Saneamento Básico do Estado de São Paulo (SABESP) unidade de negócio baixo Paranapanema. A ETE está localizada na Rodovia Júlio Budisk, km 8, Presidente Prudente, São Paulo, Latitude (-22.117246º) e Longitude $\left(-51.468686^{\circ}\right)$. A Figura 19 mostra um panorama geral da ETE Limoeiro com suas principais unidades.

Figura 19: Estação de tratamento de esgoto Limoeiro (SABESP)

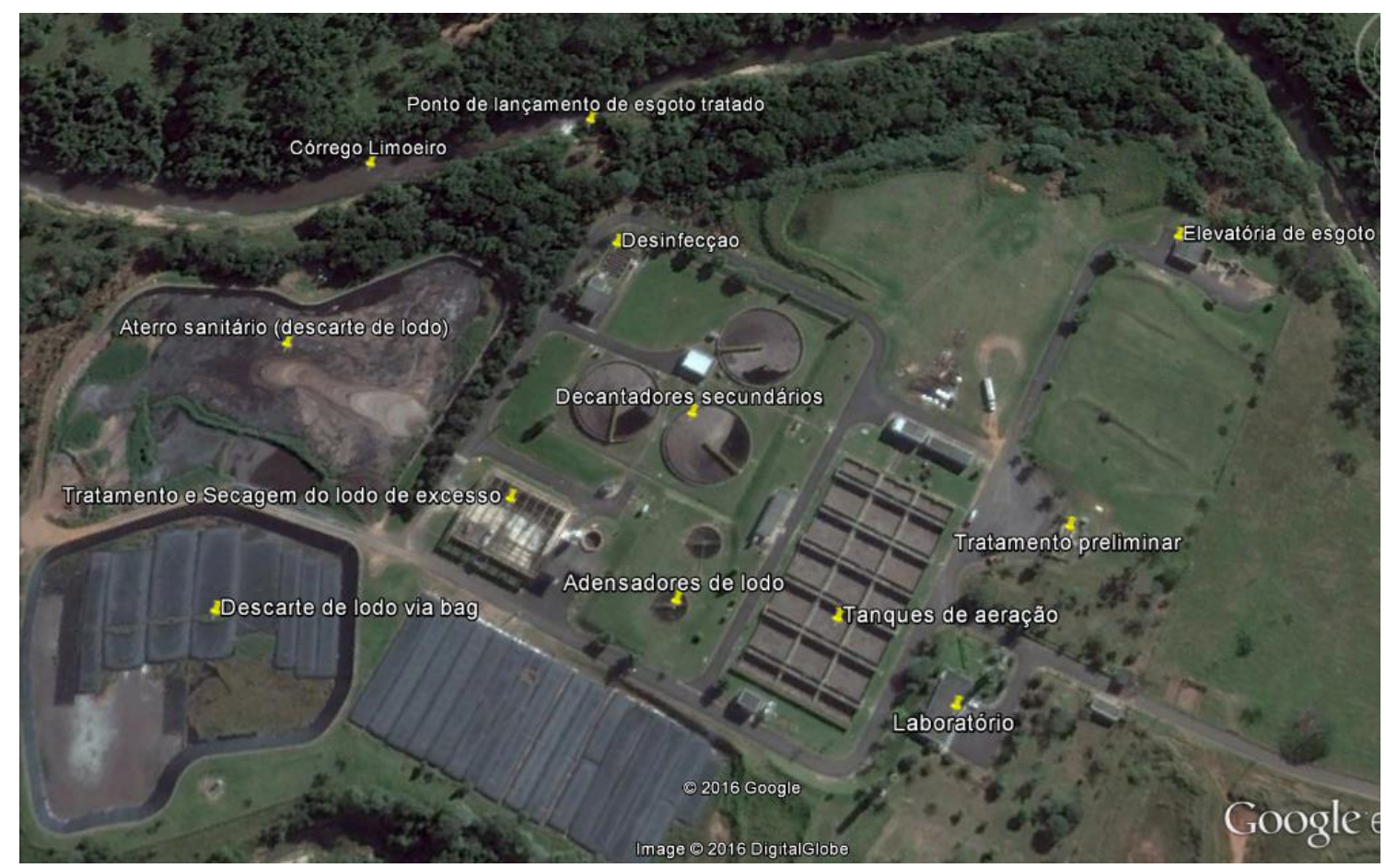

\subsection{Características principais da ETE Limoeiro da SABESP}

O esgoto chega na ETE oriundo de um sistema de captação composto por rede coletora, coletores tronco, interceptores e emissário de $1.200 \mathrm{~mm}$ de diâmetro. No ano de 2014, esse complexo sistema de coleta contava com mais de 802 km em extensão. O sistema de esgotamento sanitário do município conta com $100 \%$ de coleta e tratamento, com mais de 80.467 economias atendidas e população de 215.381 
habitantes (SNIS, 2014). A estação também recebe o esgoto do município vizinho Alvares Machado. A vazão média de tratamento de esgoto à entrada do processo foi de $475 \mathrm{~L} / \mathrm{s}$ com picos de $713 \mathrm{~L} / \mathrm{s}$ no ano de 2015.

\subsubsection{A ETE Limoeiro existente é composta de:}

$\checkmark$ Grade grossa de limpeza manual, seguida de grade fina de limpeza mecanizada;

$\checkmark$ Estação Elevatória

$\checkmark$ Desarenador gravitacional, do tipo tanque de areia de caixa quadrada, com remoção mecanizada da areia retida;

$\checkmark$ Sistema de lodos ativados composto de 03 tanques de aeração, 03 decantadores secundários e sistema de recirculação e de descarte de excesso de lodos ativados;

$\checkmark 02$ adensadores por gravidade de excesso de lodos ativados;

$\checkmark 02$ decanters centrífugos com seus acessórios para desaguamento de lodo.

\subsubsection{Gradeamento, estação elevatória e desarenação}

O esgoto que chega na ETE passa por um sistema de retenção de sólidos grosseiros, constituído de uma grade grossa manual (abertura de $50 \mathrm{~mm}$ ) e duas grades finas de limpeza automática (tipo cremalheira, com abertura de $10 \mathrm{~mm}$ ), sendo que o material retirado verte numa esteira transportadora que direciona o resíduo para caçambas e posteriormente este é disposto em aterro sanitário. A seguir, passa por um sistema de medição de vazão constituído de uma calha Parshall com medidor ultrassônico, chegando no poço de sucção da estação elevatória de esgoto bruto. A Figura 20 mostra as principais características do tratamento preliminar do esgoto à entrada do processo de lodos ativado. 
Figura 20: Tratamento preliminar do esgoto à entrada do processo de lodos ativados
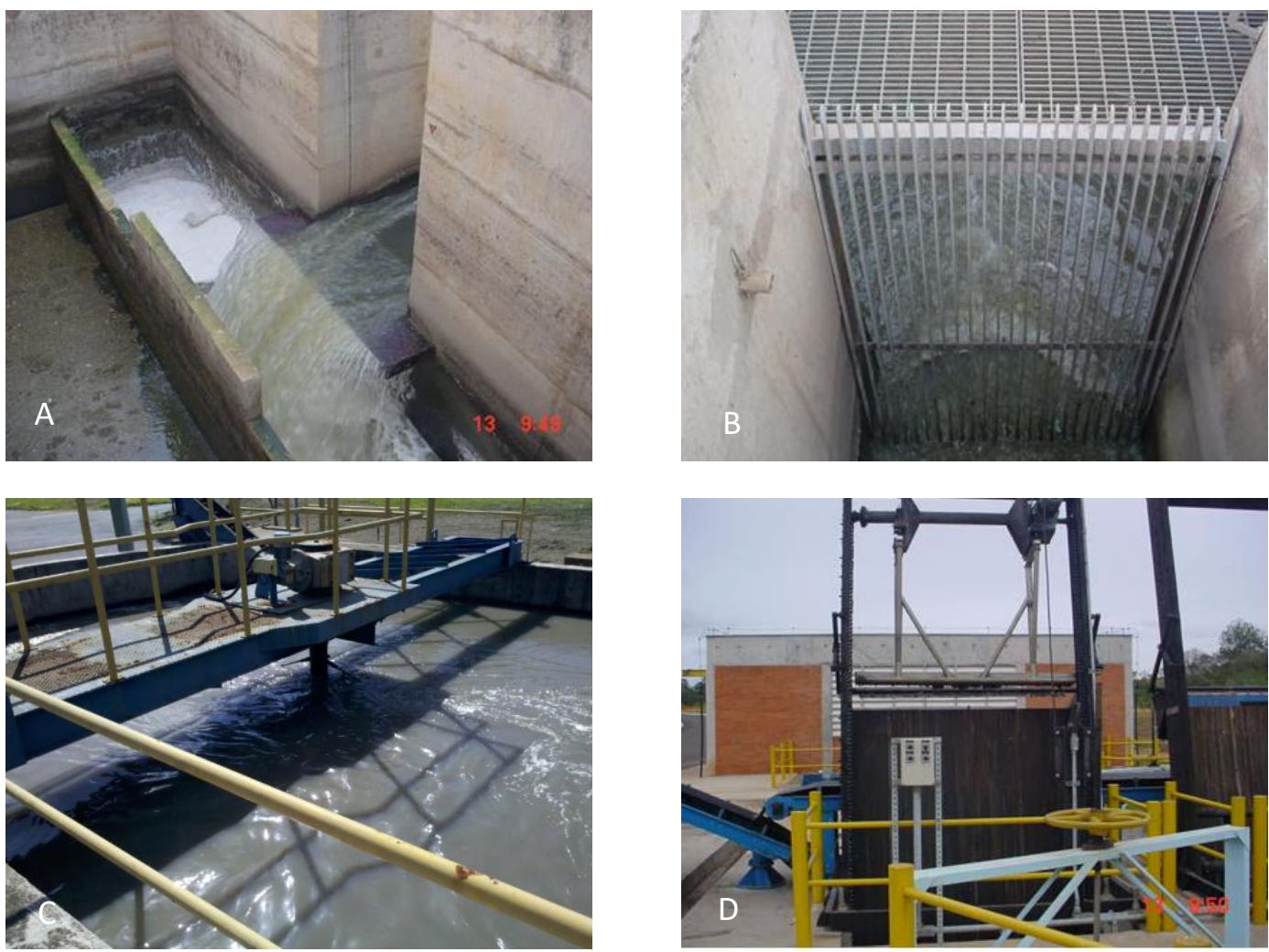

Legenda: Canal de chegada do esgoto bruto (A); Gradeamento grosseiro (B); Desarenador mecanizado (C) e Gradeamento fino com limpeza mecanizada (D).

\subsubsection{Estação Elevatória de Esgoto Bruto}

Na estação ocorre o bombeamento do esgoto acumulado no poço de sucção através de três conjuntos moto-bombas de $75 \mathrm{kw}$ cada (vazão máxima de $385 \mathrm{~L} / \mathrm{s}$ cada conjunto), sendo que o sistema trabalha automaticamente utilizando recursos como CLP e inversor de frequência e ainda, para a situação de falta de energia elétrica, existe um gerador de $275 \mathrm{KVA}$ que garante o contínuo funcionamento da unidade. $\mathrm{O}$ recalque do esgoto tem como ponto de chegada, a entrada do desarenador. A Figura 21 mostra o conjunto moto-bomba instalado na ETE Limoeiro. 
Figura 21: Conjunto moto-bomba de recalque de esgoto à entrada do desarenador
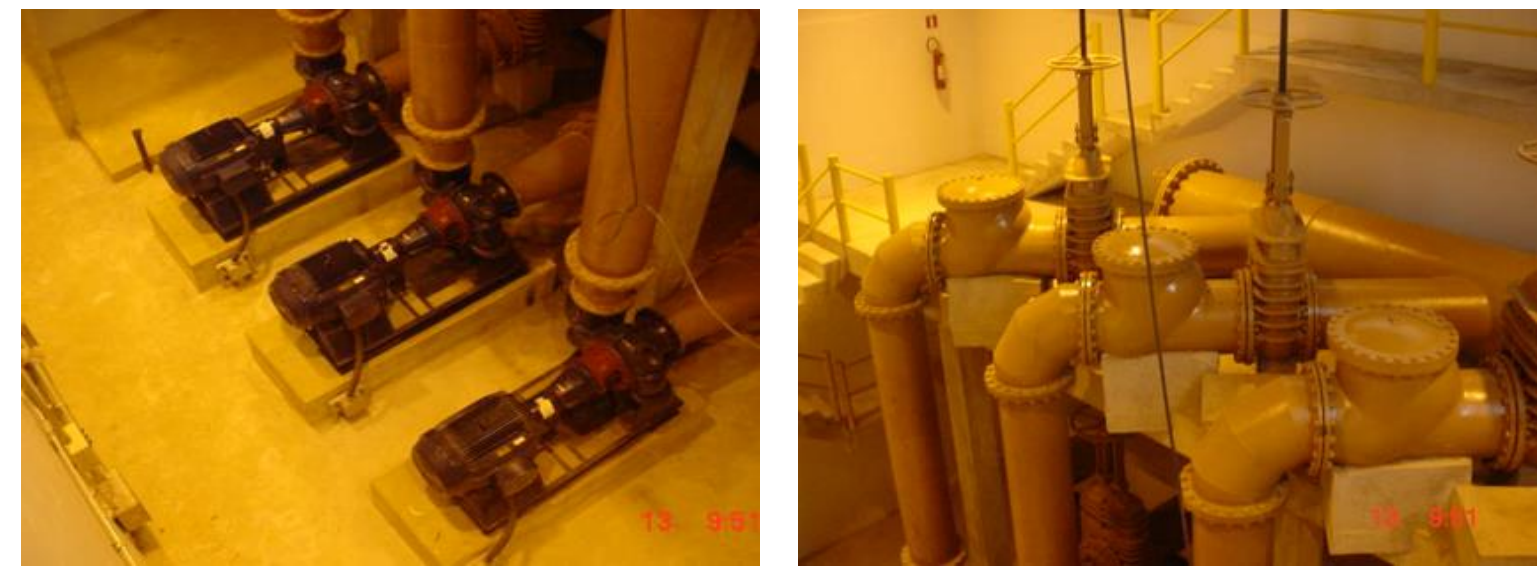

\subsubsection{Desarenadores}

São duas unidades do tipo tanque quadrado, que trabalham em paralelo. Nestes equipamentos, há uma redução da velocidade do esgoto, o que faz com que a areia se deposite no fundo, de onde um sistema de raspadores e transportadores helicoidais remove para caçambas. A areia retirada é enviada para aterro sanitário. Na sequência o fluxo do esgoto flui por gravidade até a caixa distribuidora de vazão.

Principais características das unidades:

$\checkmark$ Lados do tanque $=7,0 \mathrm{~m} \times 7,0 \mathrm{~m}$

$\checkmark$ Largura do canal $=1,0 \mathrm{~m}$

$\checkmark$ Área superficial $=49,0 \mathrm{~m}^{2}$ por unidade;

$\checkmark$ Área superficial total $=98,0 \mathrm{~m}^{2}$ no total;

Remoção da areia - através de parafuso rosca sem fim, com deposição temporária da areia em caçambas, com aplicação de cal sobre o material acumulado. A Figura 22 mostra o desarenador do tipo tanque quadrado com limpeza mecanizada instalado na ETE Limoeiro. 
Figura 22: Desarenador do tipo tanque quadrado com limpeza mecanizada
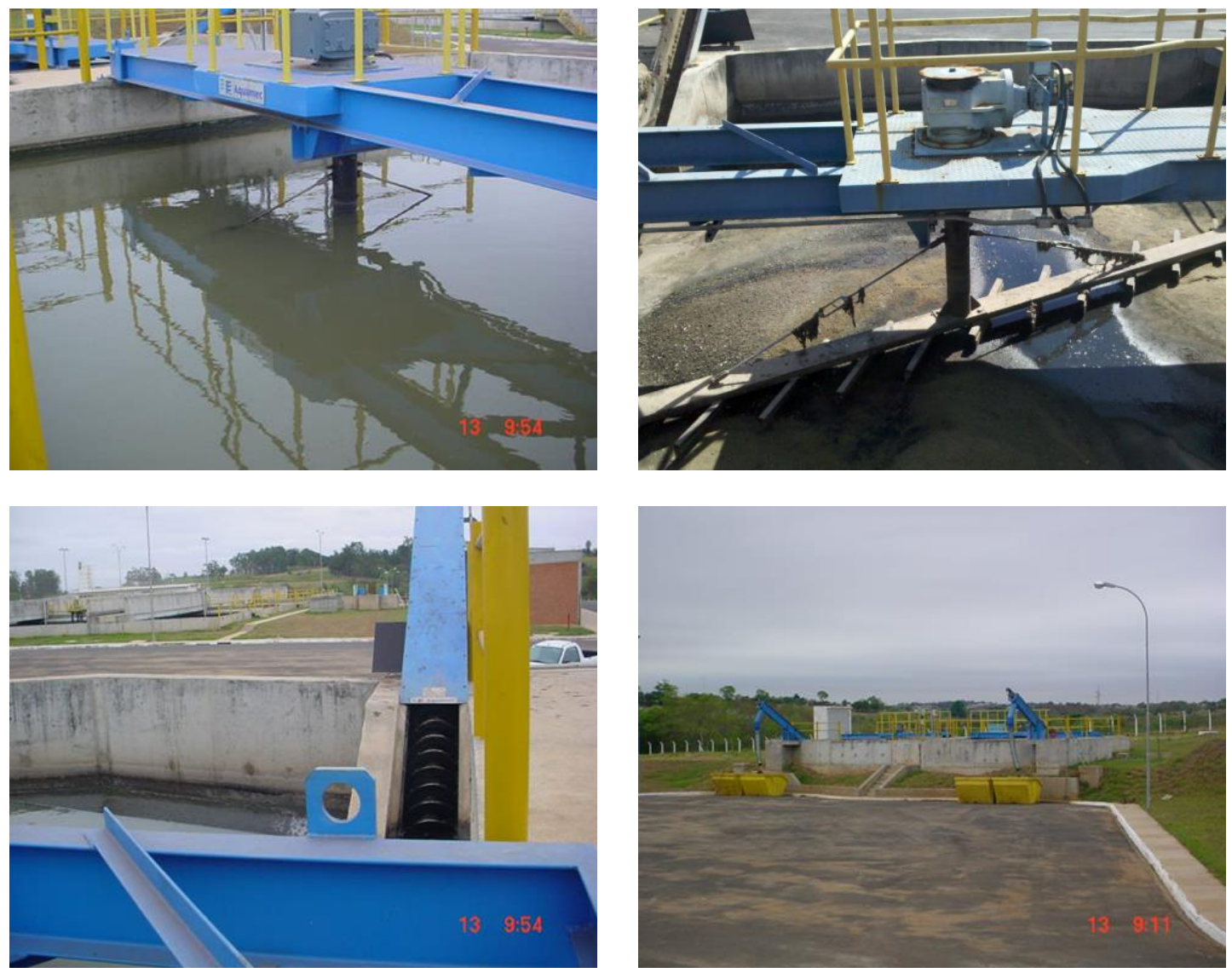

\subsubsection{Caixa distribuidora de vazão}

Na Figura 23, observa-se a caixa distribuidora de vazão, nesse local é feito a mistura do lodo recirculado, o chamado lodo ativado com o esgoto que está chegando, oriundo do desarenador, para tratamento, e a distribuição da mistura resultante para os três tanques de aeração.

Figura 23: Caixa distribuidora de vazão de esgoto

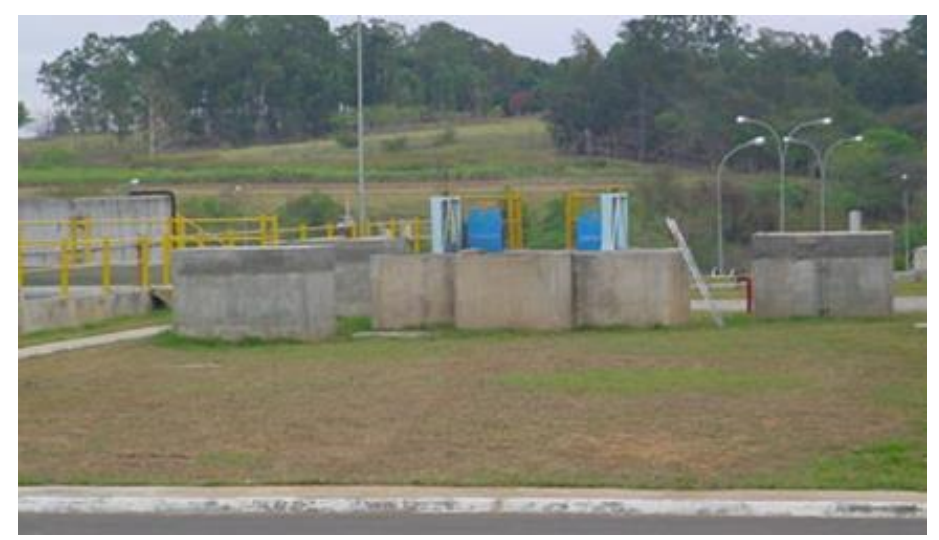




\subsubsection{Características dos tanques e do sistema de aeração da ETE Limoeiro}

A ETE Limoeiro é do tipo lodo ativado com aeração prolongada de fluxo contínuo, possuindo 03 (três) tanques de operação alimentados com os esgotos em paralelo. Características de cada tanque de aeração:

Comprimento $=102,0 \mathrm{~m}$

Largura $=17,3 \mathrm{~m}$

Profundidade útil $=5,3 \mathrm{~m}$

"free board" = 0,5 m

Volume útil de cada tanque $=9.353 \mathrm{~m}^{3}$

\subsubsection{Sistema de aeração e mistura do lodo ativado}

$\mathrm{Na}$ concepção original da ETE, o sistema de aeração era feito por aeradores / misturadores do tipo hyperbolic classic Invent (Modelo HCRBKG/2500-30kW - 42 rpm) com motor de $30 \mathrm{~kW}(40 \mathrm{cv})$, cada tanque contava com 08 aeradores. No decorrer da operação do processo de lodos ativados, o sistema de aeração foi substituído por difusores circulares de membrana de bolha fina, com sistema triplo, ante entupimento, com elevada transferência de oxigênio, com vazão de trabalho mínima de $0,020 \mathrm{~m}^{3} / \mathrm{min}$ e máximo de $0,120 \mathrm{~m}^{3} / \mathrm{min}$ (Marca: $B \& F$ dias).A substituição completa do sistema de aeração teve término no mês de maio de 2012. A Figura 24 mostra a substituição do aerador/misturador hiperbólico para o sistema de ar difuso.

Figura 24: Substituição do sistema de aeração dos tanques da ETE Limoeiro
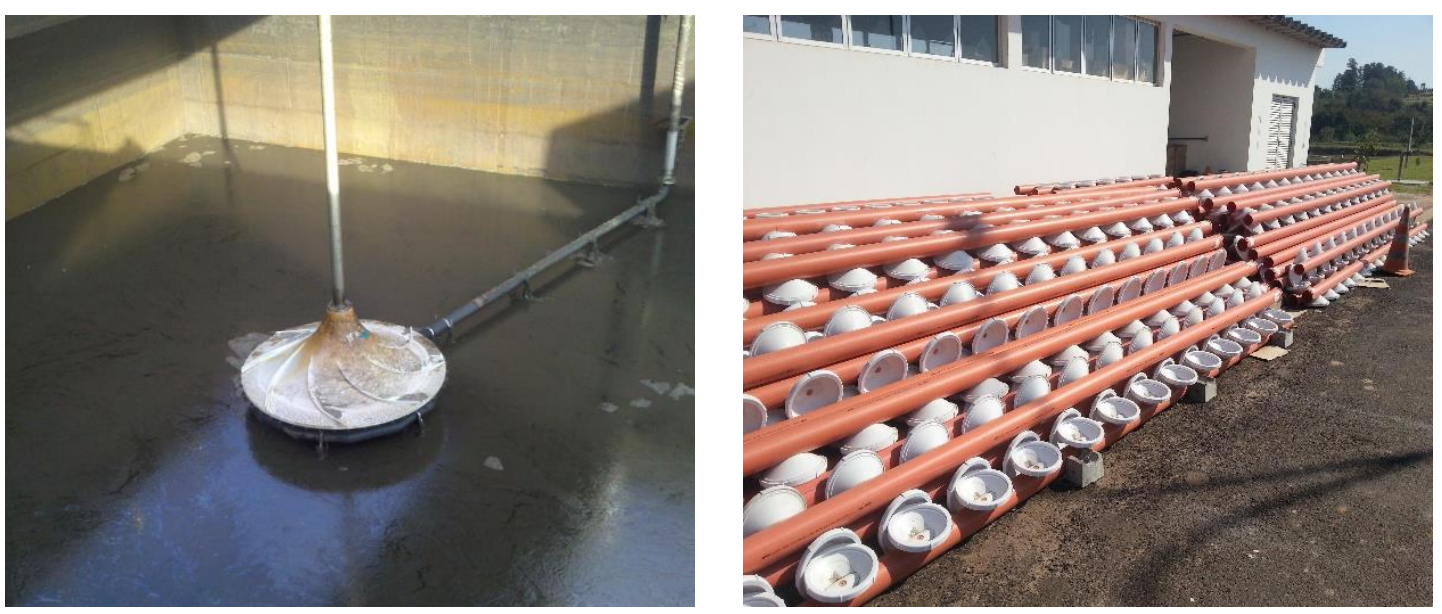


\subsubsection{Fornecimento e controle da aeração}

O fornecimento de ar é feito por meio de 05 (cinco) sopradores tipo roots com capacidade, cada um, para até $6.120 \mathrm{Nm}^{3} \mathrm{Ar} / \mathrm{h}$, para o soprador com $1.970 \mathrm{rpm}$ (motor com 1.750 rpm). Para 04 (quatro) sopradores em operação, a capacidade total de produção de ar é de $24.480 \mathrm{Nm}^{3}$.ar/hora. Para a entrada do quinto soprador, nas horas de pico, pode chegar a $30.600 \mathrm{Nm}^{3}$.ar/hora. Cada conjunto de soprador tem motor de $200 \mathrm{cv}$, todos controlador por meio de inversores de frequência. Na operação anterior ao estudo, existia 01 (um) sensor de concentração de oxigênio dissolvido (OD) em cada tanque para o comando da vazão de ar a ser fornecida pelos sopradores. Como os tanques de aeração possuem relação comprimento / largura da ordem de 6/1, o comportamento do regime de escoamento não é o de mistura completa ideal. Neste caso, ocorre maior consumo de oxigênio no trecho inicial do tanque de aeração, por onde ingressa a carga orgânica, reduzindo-se progressivamente ao longo do comprimento até a saída no lado oposto, ponto em que a carga já foi substancialmente reduzida.

Desta forma é preciso que os sopradores de ar enviem quantidades proporcionais de oxigênio para os diversos setores do tanque de aeração, para a racionalização do processo e do consumo de energia. Nesta pesquisa, para o desenvolvimento da nitrificação e desnitrificação simultânea (NDS), foi necessário a otimização do sistema de controle de OD nos tanques de aeração para o comando da vazão dos sopradores de ar. Assim, foram implantados 03 (três) sensores de OD em cada tanque de aeração, de forma a produzir três zonas de lodo com oxigenação controlada de forma independente, permitindo o controle mais rigoroso do valor estabelecido para o OD na fase experimental. A Figura 25 mostra o arranjo experimental e disposição das sondas de OD instaladas nos tanques de aeração. 
Figura 25: Arranjo experimental e disposição das sondas de OD nos tanques de aeração.

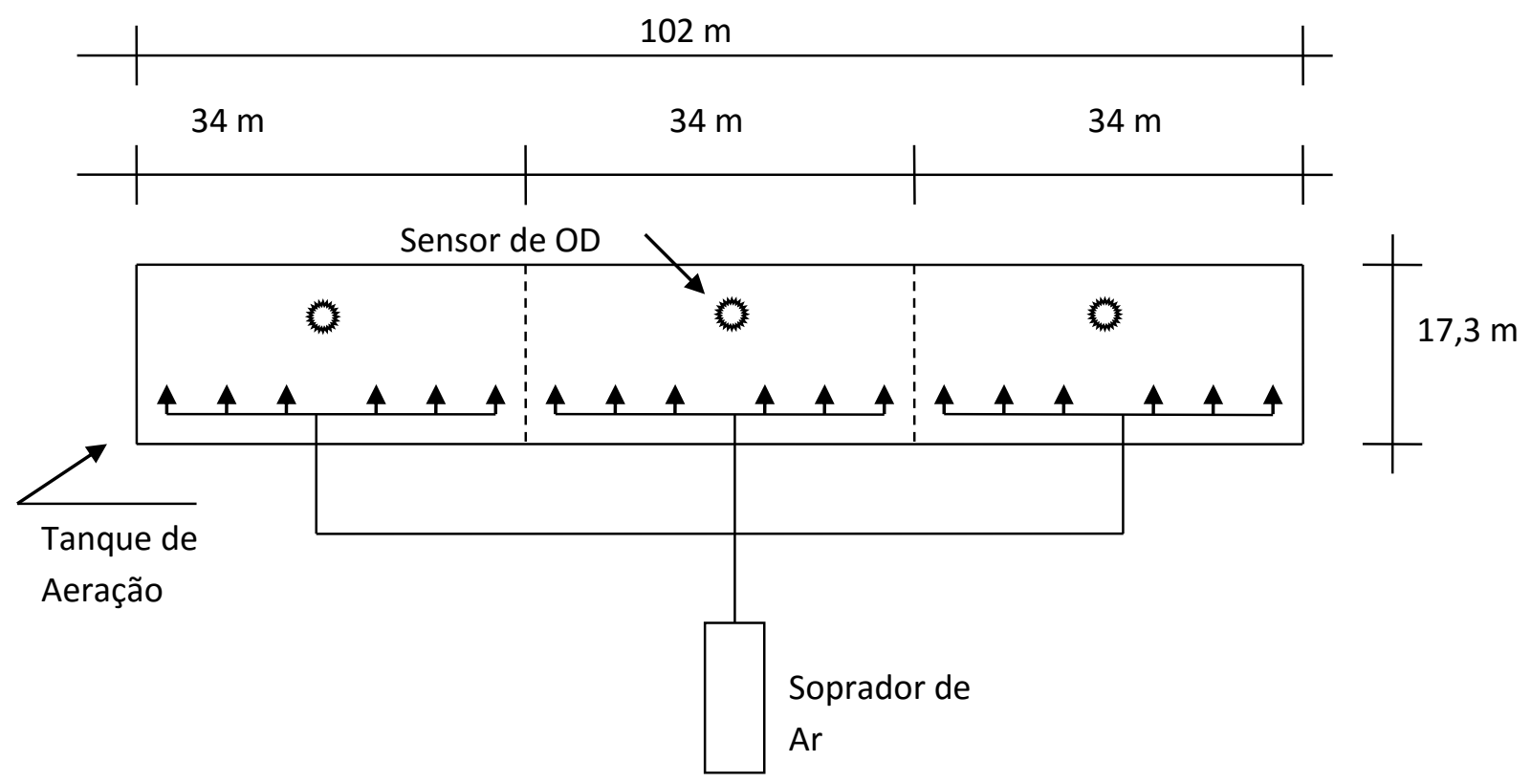

Para o controle da aeração, levou-se em conta o comportamento dinâmico da estação de tratamento de esgoto, em relação às variações de vazão e cargas afluentes, de modo a melhorar o desempenho do processo, redução de custos operacionais, estabilidade do sistema e o desenvolvimento da NDS. A Figura 26 ilustra o comportamento esperado com a otimização do sistema de aeração.

Figura 26: Variação no tempo da entrada e saída de processo (a) não-controlado e (b) controlado. Adaptado de Andrews, 1974

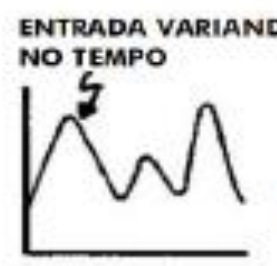

(a)
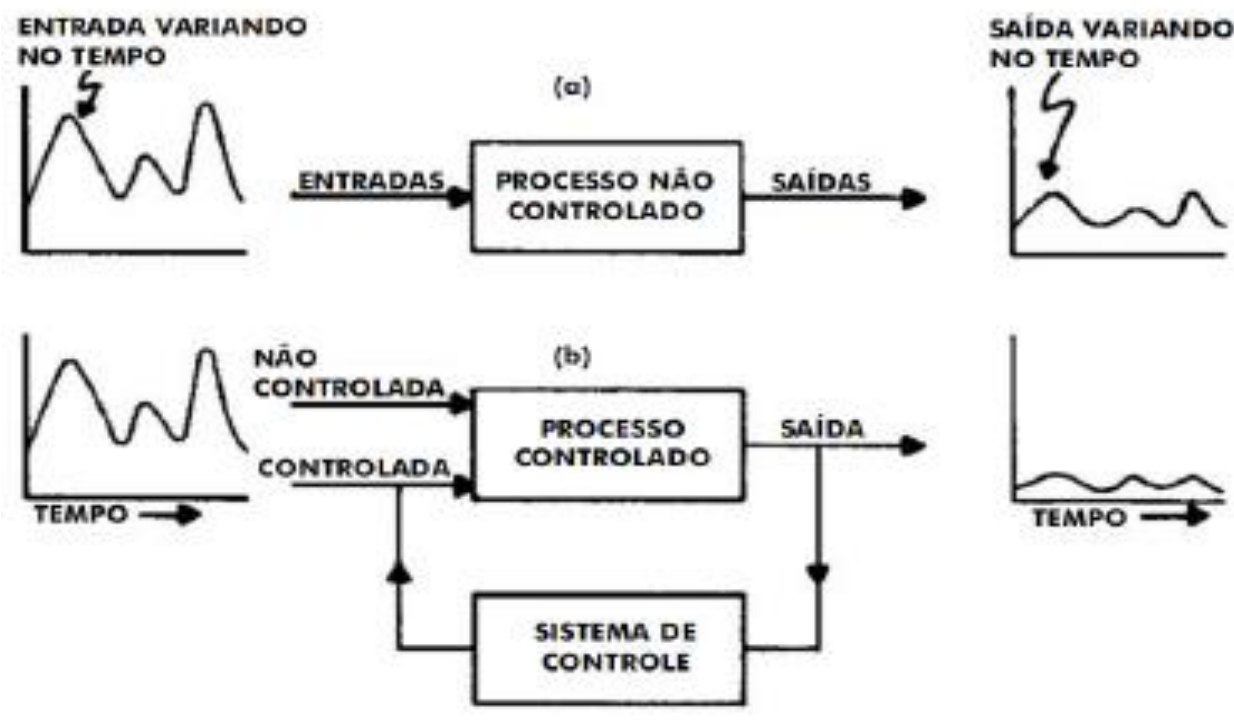
O principal desafio no controle da aeração é determinar a alteração necessária na variável manipulada para que a variável controlada seja mantida próxima ao "setpoint" estabelecido. Para isso existem diversas metodologias, indo das mais elementares, como liga-desliga (manual), até metodologias com algoritmos mais sofisticados como predição e adaptação. No controle do sistema de aeração, a principal variável controlada é a concentração de oxigênio dissolvido no tanque de aeração, enquanto a variável manipulada correspondente está relacionada com o fornecimento de ar/oxigênio. No caso de aeradores por ar difuso, a variável manipulada será a vazão de ar, que pode ser determinada pela abertura ou fechamento de uma válvula ou com a variação da rotação de um soprador. Na ETE Limoeiro, o controle da vazão de ar foi por meio da variação da rotação do soprador, que só é possível com inversores de frequência, que permite aumentarmos ou diminuirmos a vazão de ar de maneira estável de modo a suprir a demanda de OD dentro dos tanques de aeração sem que haja prejuízos para o processo de tratamento. A Figura 27 mostra o fluxograma resumido do sistema de controle da aeração implantado na ETE Limoeiro.

Figura 27: Estrutura resumida do controle de oxigênio dissolvido no tanque de aeração.

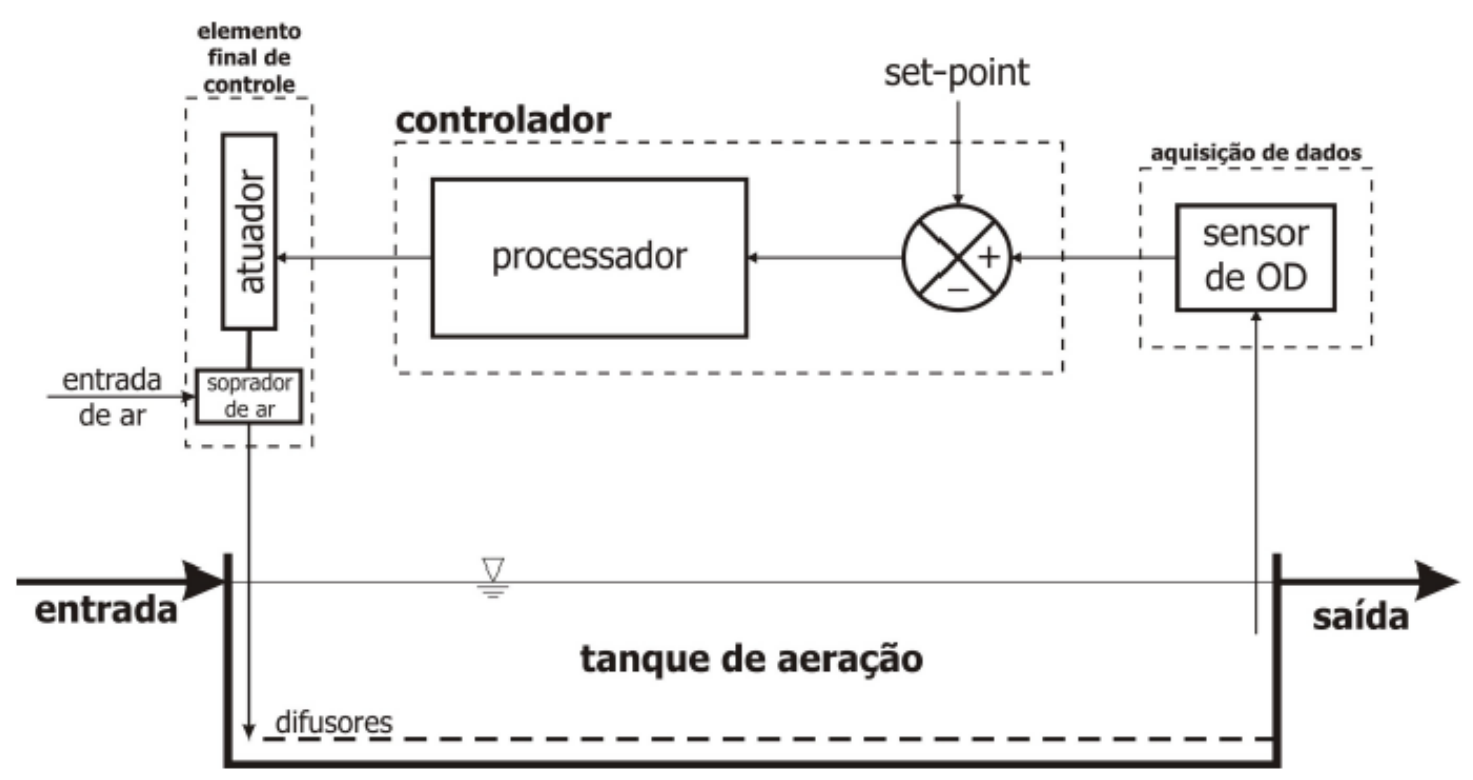




\subsubsection{Características dos controladores e sensores de monitoramento online de OD, pH, REDOX e Nitrato implantados na ETE Limoeiro}

O controlador do sistema de aeração e das variáveis de monitoramento online foi o modelo SC1000, da Hach, origem EUA. Cada controlador possui 4 entradas/saídas digitais ou analógicas para sensores de processo, com transmissão de dados via RS485 ou MODBUS. Os sensores de oxigênio dissolvido foram os de LDO (oxigênio dissolvido luminescente) modelo 2, da Hach, origem EUA. Os sensores de LDO são de resposta rápida, calibração automática, baixa manutenção. A faixa de medição é de 0,00 a $20,00 \mathrm{mgO}_{2} / \mathrm{L}$, com resolução de $0,01 \mathrm{mgO}_{2} / \mathrm{L}$ e precisão de $<0,05 \mathrm{mgO}_{2} / \mathrm{L}$. Ainda, nos tanques de aeração foram instalados sensores de $\mathrm{pH}$ de processo com leitura na faixa de 0 a 14 e eletrodo de potencial redox (ORP) na faixa de medição de $-1500 \mathrm{a}+1500 \mathrm{mV}$, ambos da marca Hach. Todos os dados transmitidos pelos sensores foram registrados e enviados ao supervisório por meio de um CLP da marca Schneider. A Figura 28 mostra o controlador e o CLP instalados na ETE Limoeiro e a Figura 29 mostra os sensores de LDO, pH e Redox instalados no tanque de aeração.

Figura 28: Equipamentos de controle do sistema de aeração

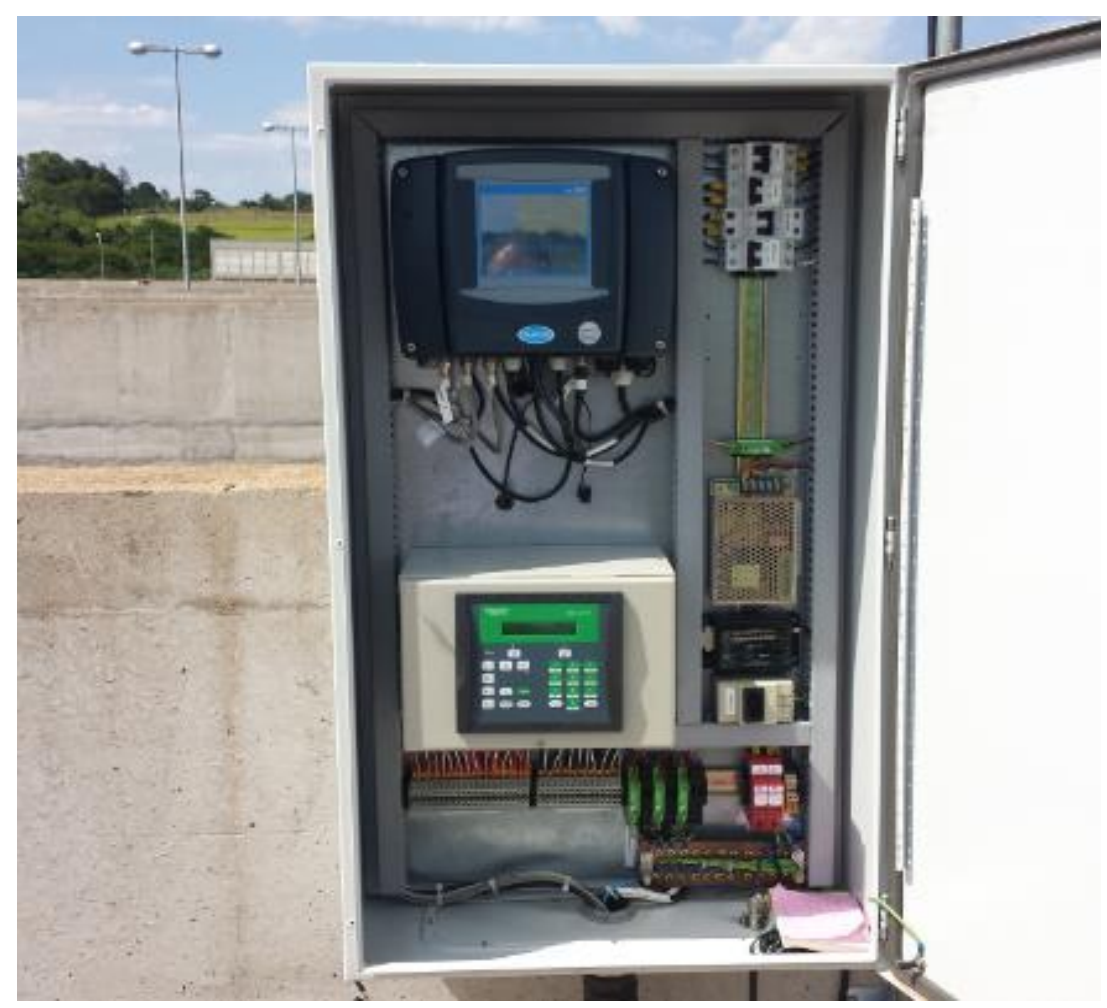


Figura 29: Vista dos sensores de LDO, pH e Redox instalados no tanque de aeração

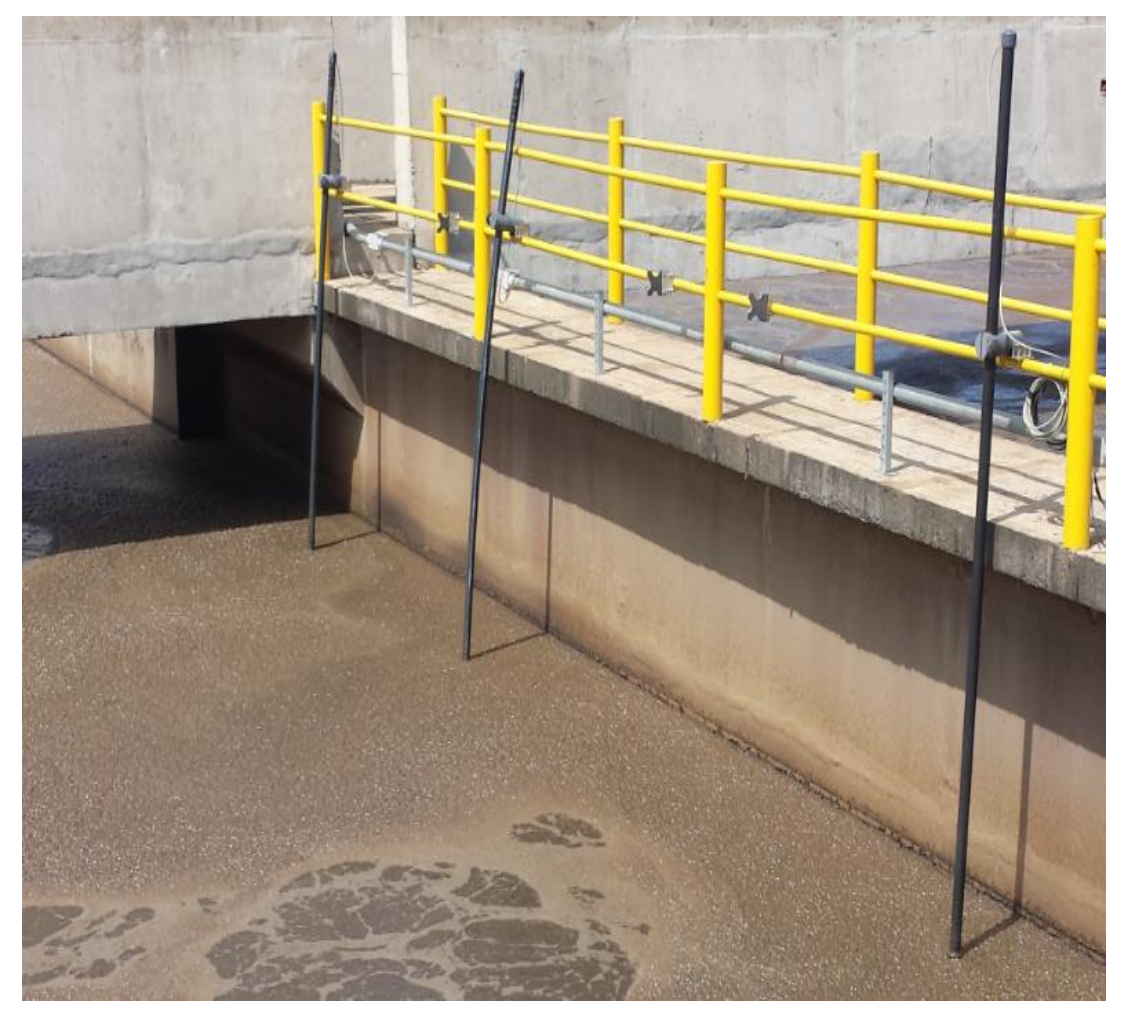

O sensor de nitrato foi instalado no canal de entrada do tanque de contato, onde a agitação do esgoto era menor, porém antes da dosagem de cloro no esgoto tratado. O sensor utilizado foi o $\mathrm{NO}_{3} \mathrm{D}$ SC, marca Hach, origem EUA.

Características do sensor:

* Princípio de Medição: Ion Seletivo

* Faixa de Medição: 0 - $1000 \mathrm{mg} / \mathrm{L} \mathrm{NO}{ }_{3}-\mathrm{N}$

* Precisão: $5 \%$ do valor medido ou +/- 0,2 mg/L (com solução padrão)

* Tempo de Resposta (T90): menos que 3 minutos

* Temperatura de Operação: -20 à $45^{\circ} \mathrm{C}$

* Temperatura da Amostra: 2 à $40^{\circ} \mathrm{C}$

* pH da Amostra: 5 à 9

* Profundidade de Imersão Sensor: 0,3 à 3,0 metros

* Pressão Máxima Sensor: 0,3 Bar (4,4 psi)

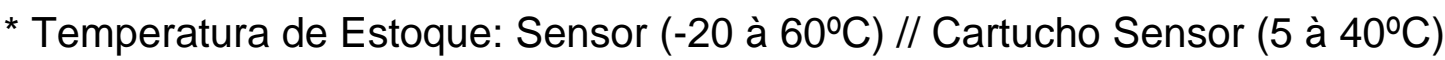


* Calibração: calibração de fábrica, inserção de código presente no cartucho do sensor.

* Material do Sensor: aço inox 316 com partes em Ryton

Para evitar desgaste do sensor e interferência de sólidos foi instalado um compressor específico de limpeza do sensor nitrato/amônia, modelo SC115V, marca Hach. A Figura 30 mostra o ponto de instalação do sensor e o painel de controle da medição.

Figura 30: Sistema de controle de Nitrato instalado no canal do efluente final
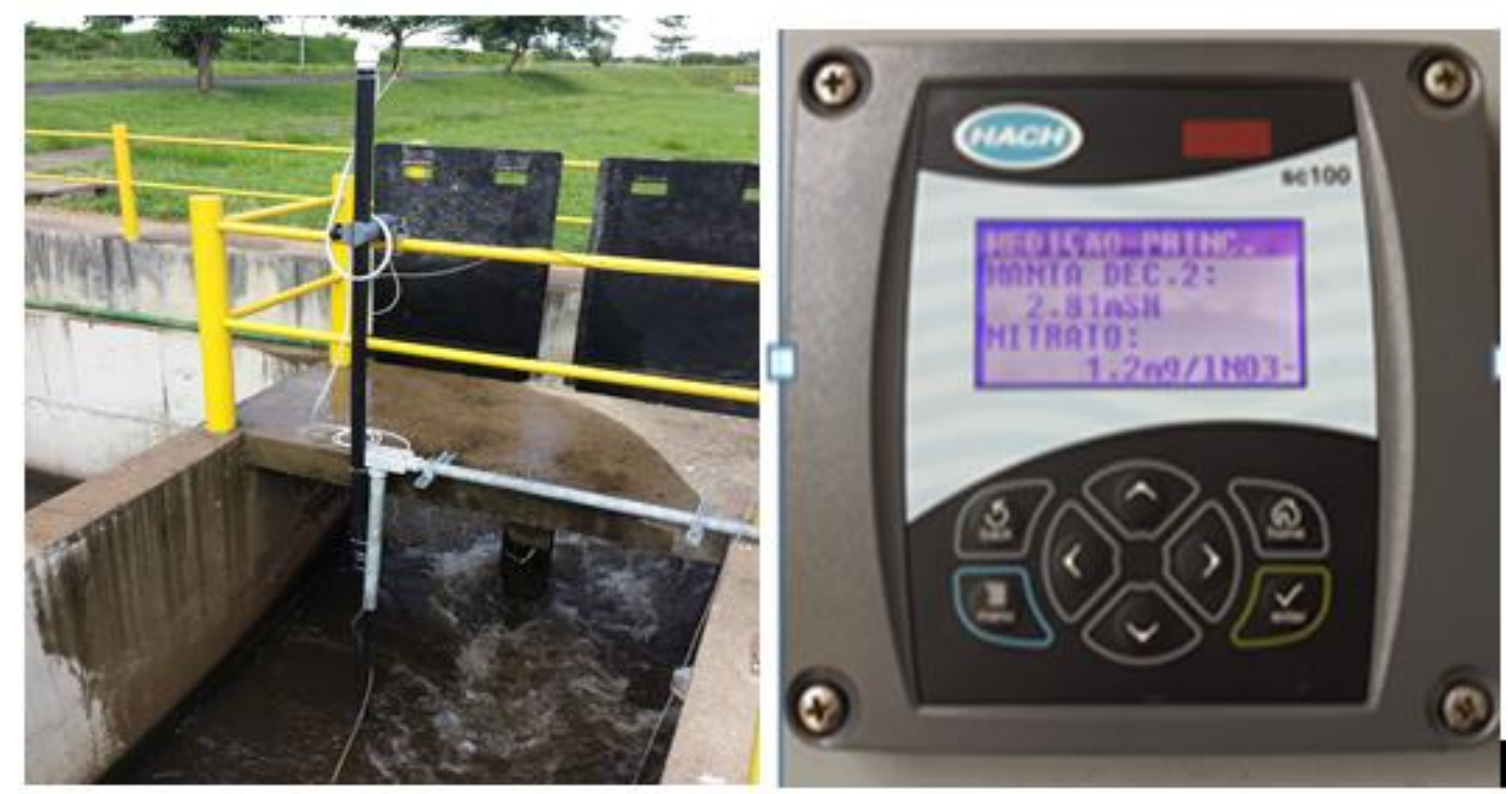

\subsubsection{Decantadores secundários}

O esgoto tratado nos tanques de aeração flui para os decantadores entrando nos mesmos pelo centro e vai fluindo lentamente para as bordas, fazendo com que o lodo sedimente e seja retirado pelo fundo, saindo o esgoto decantado já tratado pela canaleta coletora externa de onde é encaminhado para o tanque de contato. Características dos decantadores:

Número de unidades implantadas $=03$

Diâmetro dos decantadores $=36,0 \mathrm{~m}$

Área por decantador $=1.017,9 \mathrm{~m}^{2}$

Área total de decantação $=3.053,6 \mathrm{~m}^{2}$ 
A Figura 31, mostra os decantadores secundários implantados na ETE Limoeiro.

Figura 31: Vista dos decantadores secundários da ETE Limoeiro
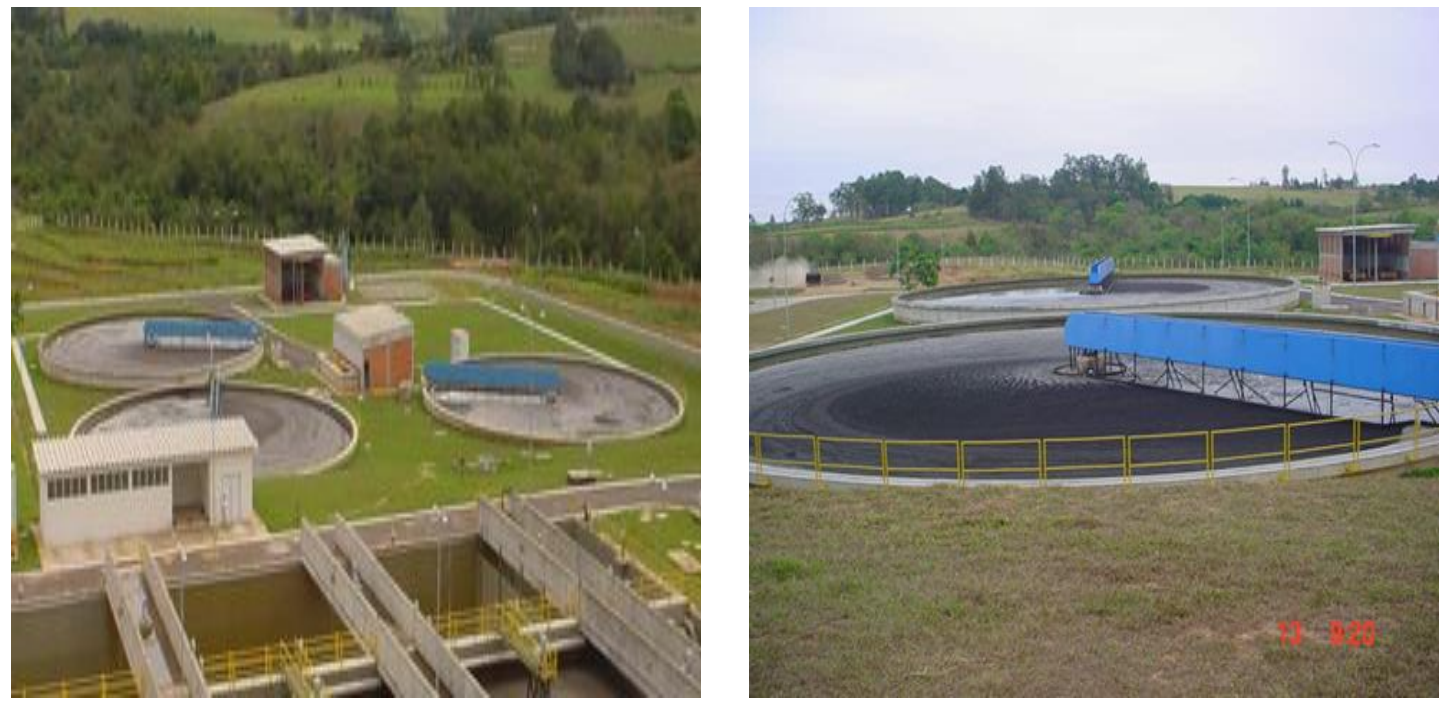

\subsubsection{Estação Elevatória de Recirculação de Lodo}

O lodo retirado dos decantadores secundários é bombeado por meio de 03 conjuntos moto-bombas de $75 \mathrm{CV}$ (cada) de volta para o processo de aeração, retornando para a caixa divisora de vazão situada após os desarenadores (Figura 32). O excesso de lodo é retirado e enviado para o sistema de desidratação, ou seja, aos adensadores de lodo.

Figura 32: Caixa divisora de vazão e conjunto moto-bombas
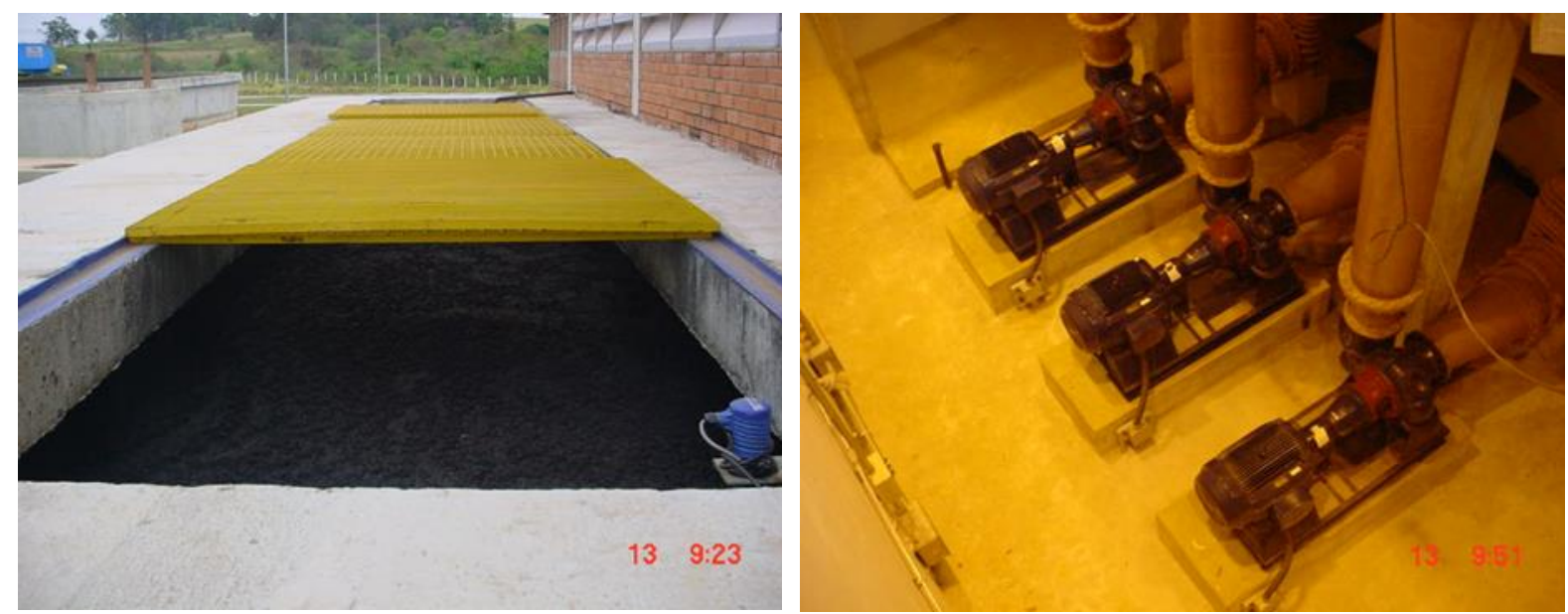


\subsubsection{Adensamento do excesso de lodo ativado}

Constitui-se no primeiro processo para a retirada do excesso de água do lodo na ETE Limoeiro, onde o teor de sólidos atinge um valor próximo a 2,5 por cento. São dois adensadores por gravidade com 13 metros de diâmetro e 3,8 metros de profundidade com área de $132,7 \mathrm{~m}^{2}$, cada tanque. Nestes tanques, o lodo a ser desidratado entra pelo centro e flui lentamente para as bordas, onde sai o líquido a ser extraído. O lodo adensado vai para o fundo de onde é enviado para o tanque de armazenamento de lodo que alimenta as centrífugas. O tanque de armazenamento de lodo possui diâmetro de $9,0 \mathrm{~m}$ e volume útil de $200 \mathrm{~m}^{3}$, e a homogeneização do lodo é feito por meio de misturador vertical flutuante. A Figura 34, mostra os adensadores e o tanque de armazenamento implantados na ETE Limoeiro.

Figura 33: Adensadores e tanque de armazenamento de lodo
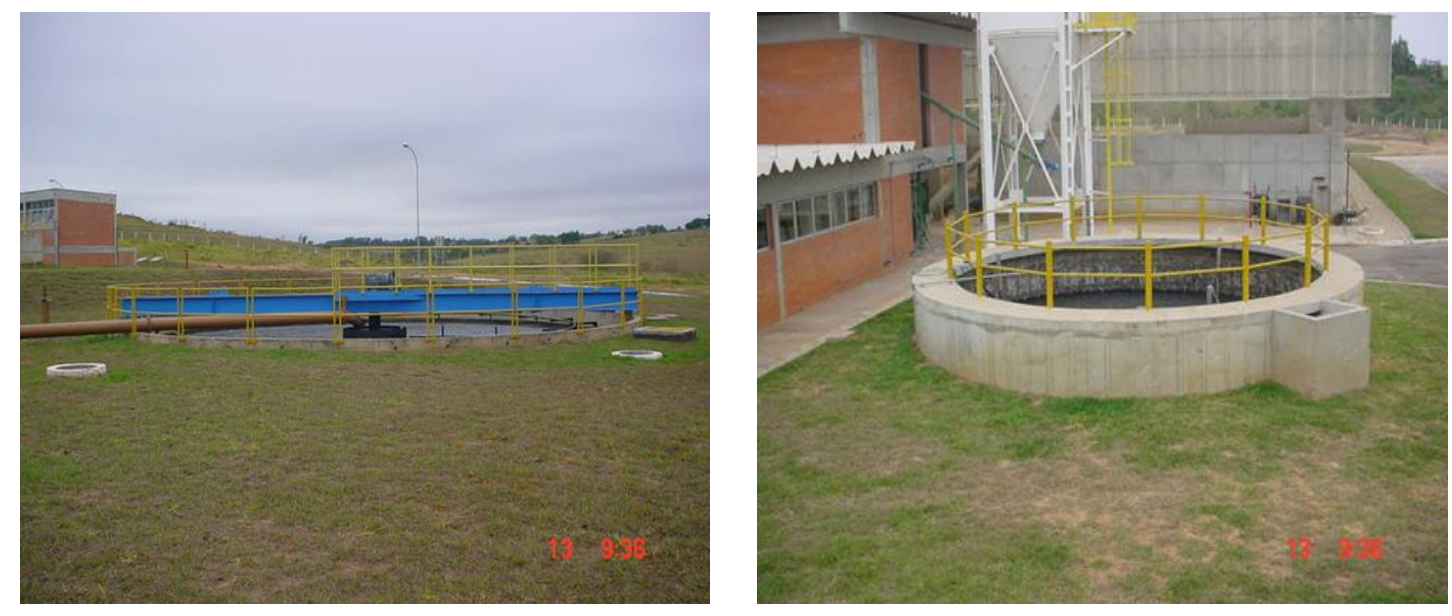

\subsubsection{Desaguamento do lodo}

O desaguamento do excesso de lodo ativado é efetuado por meio de decanters centrífugos, com aplicação de polímeros, que recebem o lodo proveniente dos adensadores e retiram a água em excesso até o teor de sólidos atingir um valor próximo a 25\% (vinte e cinco por cento). O lodo desidratado sai das centrífugas e é enviado para o sistema de mistura, onde é feita a dosagem de cal virgem para ajuste do pH do lodo. Após a mistura, o lodo é enviado para o pátio de estocagem. 
Características dos decanters centrífugos:

Número de unidades $=02$

01: Modelo - Jumbo 2 da Pieralisi

Capacidade fornecida pelo fabricante, para lodo $=15$ a $22 \mathrm{~m} 3 / \mathrm{h}$, para lodo afluente com teor de sólidos de 2 a 3\%, resultando em capacidade de sólidos de 300 a $400 \mathrm{~kg}$ sólidos/hora.

01: Modelo - Jumbo 4 da Pieralisi (instalada no ano de 2013)

Capacidade fornecida pelo fabricante, para lodo $=30$ a $44 \mathrm{~m}^{3} / \mathrm{h}$, para lodo afluente com teor de sólidos de 2 a 3\%, resultando em capacidade de sólidos de 600 a $800 \mathrm{~kg}$ sólidos/hora.

Alimentação dos decanters - 03 bombas rotativas de deslocamento positivo, para 15 a $22 \mathrm{~m}^{3} / \mathrm{h}$.

Preparo e dosagem de polímeros - sistema automatizado para uso de polímero em pó, aplicado diluído a 0,1 a 0,3\%, com capacidade de aplicação para até 3 linhas, com mais de $15 \mathrm{~kg}$ poliel./hora por linha, com injeção do polímero próximo à entrada do decanter em misturador estático, utilizando bombas dosadoras rotativas, de deslocamento positivo. A Figura 34 mostra os equipamentos implantados para o desaguamento do lodo na ETE Limoeiro.

Figura 34: Desaguamento do lodo por meio de decanters centrífugos
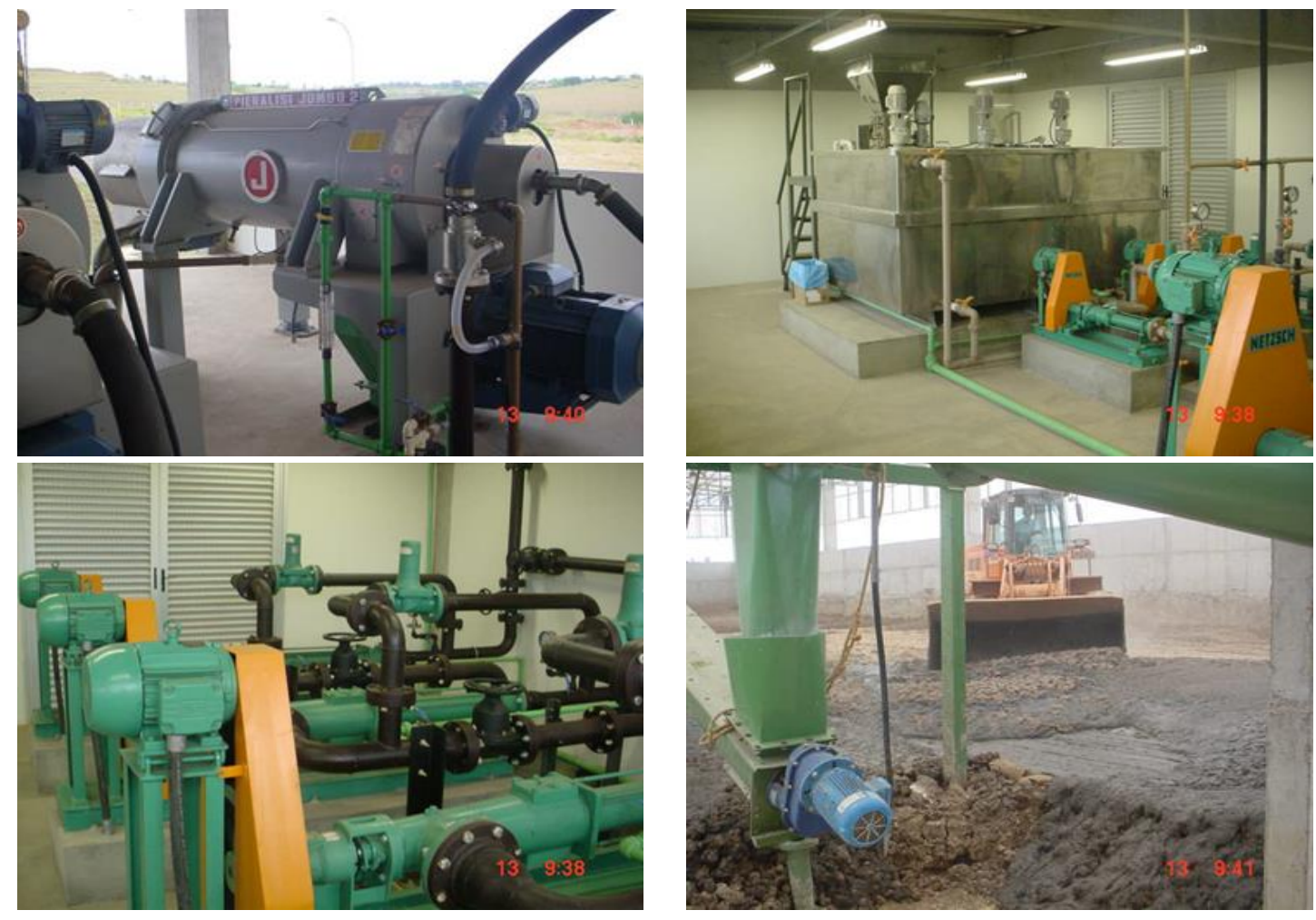


\subsubsection{Pátio para estocagem do lodo desidratado}

O pátio é coberto por um telhado transparente onde o lodo desidratado permanece por um período mínimo de 30 dias sob ventilação controlada. O elevado $\mathrm{pH}$ e a alta temperatura devido à reação exotérmica da cal virgem com a umidade do lodo, somados ao ar da ventilação levam a inativação do lodo produzido, possibilitando sua aplicação controlada na agricultura ou a destinação ao aterro sanitário na própria ETE e em casos de emergência o lodo é disposto em bags. A Figura 36, mostra o pátio de estocagem do lodo após desaguamento, o aterro sanitário e os bags.

Figura 35: Pátio de estocagem de lodo, aterro sanitário e bags.
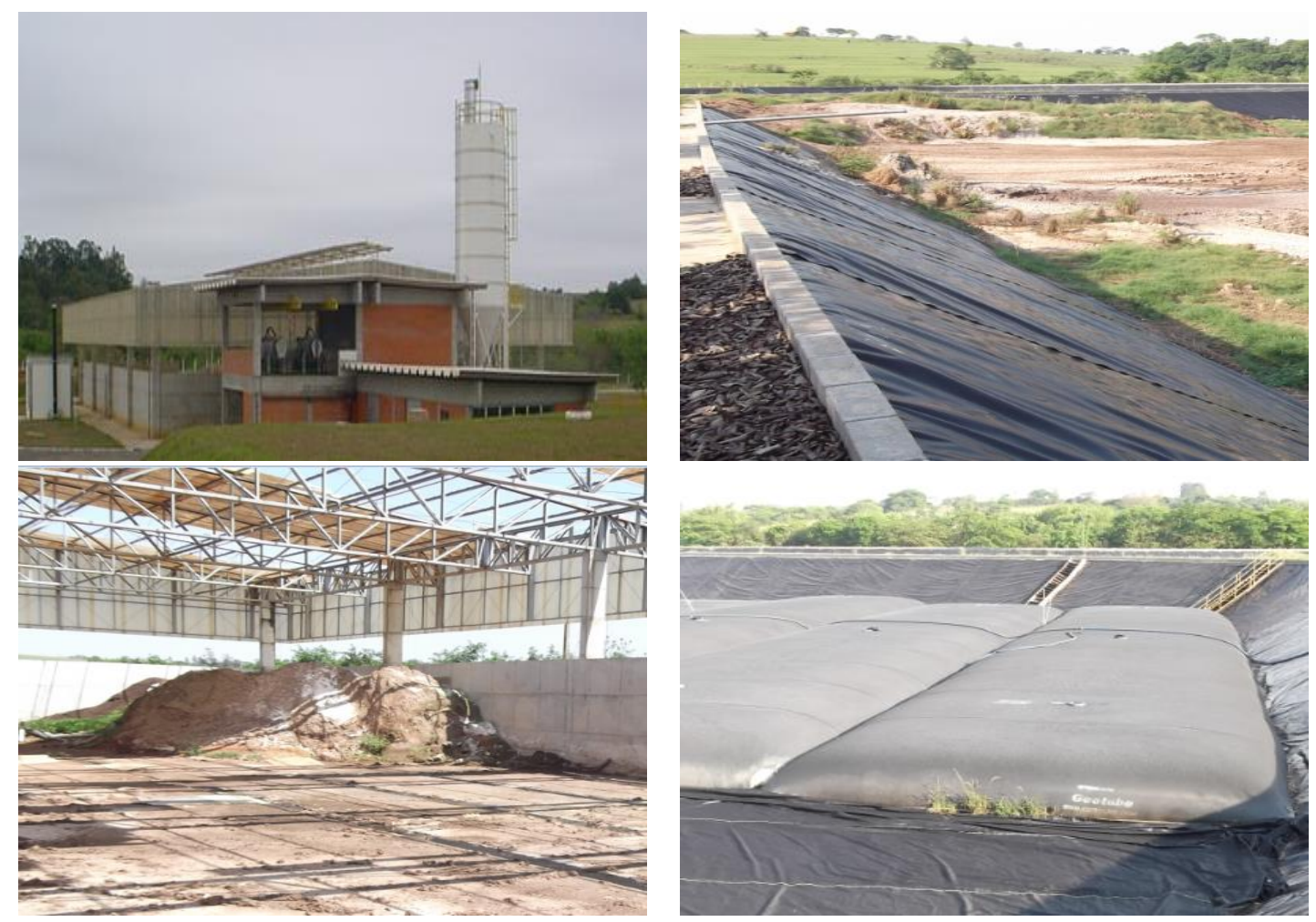

\subsubsection{Desinfecção do esgoto tratado}

A desinfecção é feita com cloro gás, aplicado à entrada do tanque de contato de cloro, que tem as seguintes características:

Número de canais $=11$ 
Comprimento de cada canal $=11,0 \mathrm{~m}$

Largura de cada canal $=1,40 \mathrm{~m}$

Profundidade $=2,10 \mathrm{~m}$

Volume do tanque de contato $=280 \mathrm{~m}^{3}$

As dosagens de cloro atualmente utilizadas para desinfecção são de ordem de 2,0 $\mathrm{mgCl}_{2} / \mathrm{L}$.

A Figura 37 mostra o tanque de contato de cloro e o local de armazenamento do cloro gás.

Figura 36: Tanque de contato e armazenamento do cloro gás
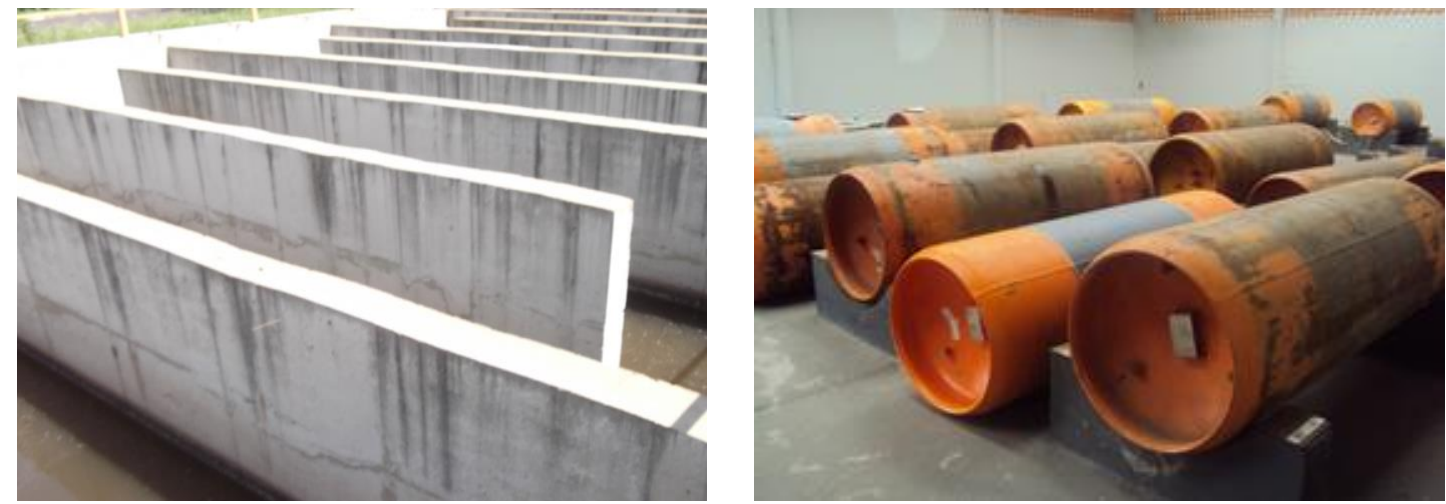

\subsubsection{Lançamento do esgoto tratado}

Após passar por uma Calha Parshall com medidor online de vazão, o esgoto desinfetado no tanque de contato é encaminhado para uma escada hidráulica, capaz de garantir um esgoto tratado final com OD maior que 2,0 mgO2/L. A Figura 37 mostra a Calha Parshall e a escada hidráulica instalados na ETE Limoeiro.

Figura 37: Calha Parshall seguido de escada hidráulica
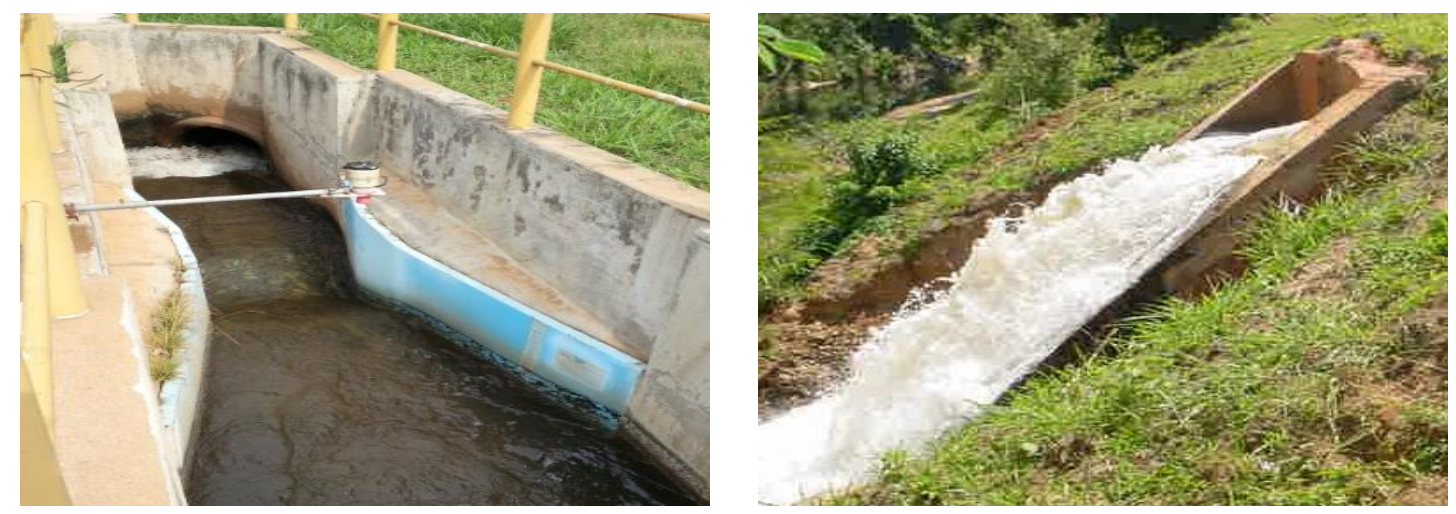


\subsubsection{Corpo Receptor}

O corpo receptor dos efluentes da ETE Limoeiro de Presidente Prudente é o Córrego Limoeiro. No ponto de lançamento, a área de drenagem é de apenas XXX km2, com vazão média plurianual estimada em XXXX l/s, vazão com permanência de $95 \%$ estimada em XXX 1/s. A vazão mínima $Q_{7,10}$ é estimada em apenas XXX 1/s. O Córrego do Limoeiro, está enquadrado na Classe 4, com os parâmetros de qualidade de água definidos na Resolução 357 de março de 2.005, do CONAMA, destacando-se o OD $\geq$ 2,0 mgO2/L. Não existem dados disponíveis sobre a qualidade do corpo receptor.

Em vista do enquadramento do corpo receptor, as principais características a serem atendidas pelo efluente da ETE são:

$$
\begin{array}{ll}
> & \mathrm{DBO}<60 \mathrm{mgO} / \mathrm{L} \\
> & \mathrm{N}-\text { Amoniacal }<20 \mathrm{mgN} / \mathrm{L} \\
> & \mathrm{OD}>2,0 \mathrm{mgO} / \mathrm{L}
\end{array}
$$

\subsection{Procedimentos Operacionais Rotineiros}

Diariamente, as condições operacionais de todos os equipamentos da ETE, principalmente os sensores instalados nos tanques de aeração, eram inspecionados pelos operadores da ETE.

\subsubsection{Determinação das Características do Afluente e dos Efluentes}

Pontos de Amostragem:

Ponto 1: Afluente aos tanques de aeração (esgoto à saída do tratamento preliminar) Ponto 2: Efluente reunido à saída dos decantadores secundários, antes da desinfecção 


\subsubsection{Variáveis Controladas, Pontos de Amostragem e Frequências}

As coletadas das amostras foram compostas de 24 horas nos pontos 1 e 2. A composição das amostras foi feita pela mistura de alíquotas coletadas em volumes proporcionais às vazões dos instantes da coleta. Para a realização das coletas foi implantado dois amostradores automáticos da marca Hach, modelo Sigma SG900. Para a proteção do amostradores foi construído dois nichos de proteção um à entrada e outro à saída da ETE. A Figura 39 mostra os amostradores instalados no local.

Figura 38: Amostrador automático com nicho de proteção implantado na ETE
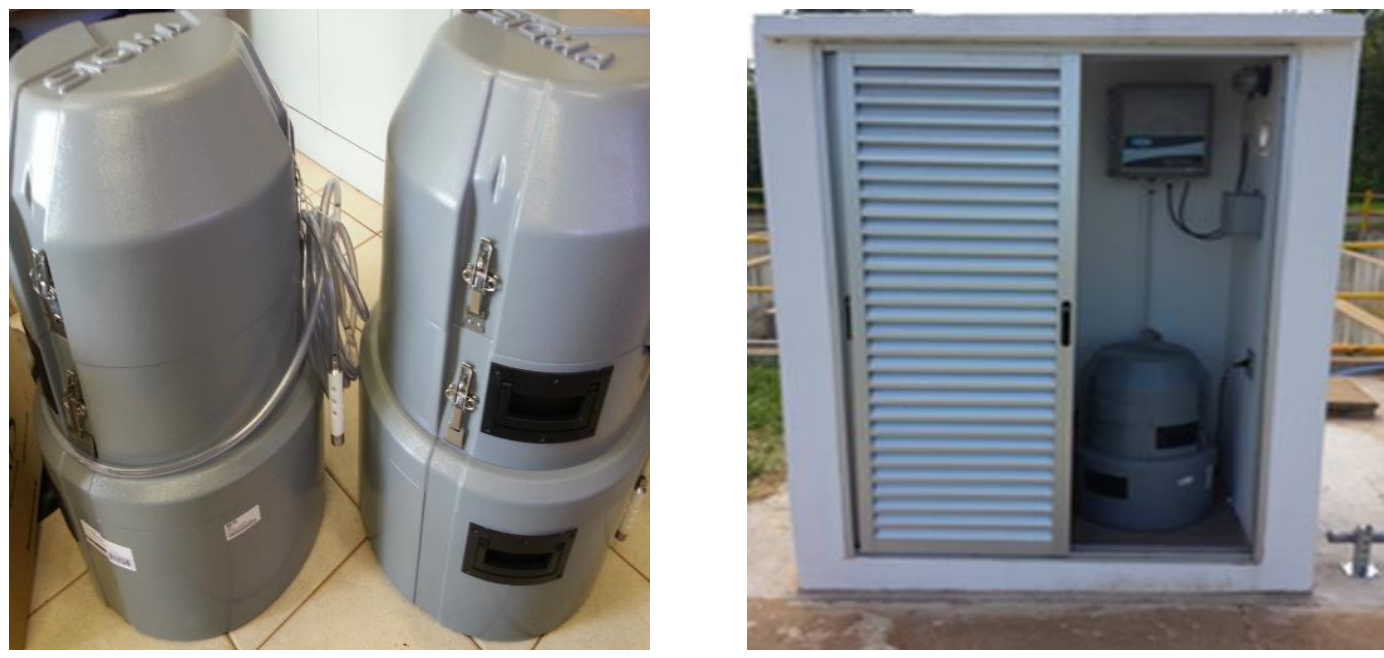

As variáveis monitoradas $\mathrm{e}$ as frequências das análises laboratoriais são apresentadas na Tabela 8 . As metodologias analíticas utilizadas seguiram à $21^{\text {a }}$ edição do Standard Methods for Examination of Water and Wastewater, da APHA / AWWA / WEF (2005). As concentrações de amônia, nitrito, nitrato e fósforo, foram quantificados em um cromatógrafo de íons (Dionex-100, coluna ASCR2_mm e CSCR2_mm). As análises foram realizadas no próprio laboratório do controle sanitário da SABESP instalado na ETE Limoeiro e em paralelo no Laboratório de Saneamento Prof. Lucas Nogueira Garcez da Escola Politécnica da USP. 
Tabela 8: Variáveis controladas nos afluentes e efluentes, pontos de amostragem e frequências

\begin{tabular}{l|c|c|c}
\hline \multicolumn{1}{c|}{ Variáveis } & $\begin{array}{c}\text { Pontos de } \\
\text { Amostragem }\end{array}$ & $\begin{array}{c}\text { Frequência das } \\
\text { Análises }\end{array}$ & $\begin{array}{c}\text { Referência Standard } \\
\text { Methods }\end{array}$ \\
\hline DQO $_{\text {total }}$ & 1 e 2 & $2 \times$ semana & Método $-5220-\mathrm{B}$ \\
\hline DQO $_{\text {solúvel }}$ & 1 e 2 & $2 \times$ semana & Método $-5220-\mathrm{B}$ \\
\hline DBO $_{5,20}$ & 1 e 2 & $2 \times$ semana & Método $-5210-\mathrm{B}$ \\
\hline DBO5,20-solúvel & 1 e 2 & $2 \times$ semana & Método $-5210-\mathrm{B}$ \\
\hline Nitrogênio Total Kjeldahl & 1 e 2 & $2 \times$ semana & Método $-4500-\mathrm{B}$ \\
\hline Nitrogênio Amoniacal & 1 e 2 & $2 \times$ semana & Método $-4500-\mathrm{B} / \mathrm{C}$ \\
\hline $\mathrm{N}-$ Nitrito & 1 e 2 & $2 \times$ semana & Método $-4110-\mathrm{B}$ \\
\hline $\mathrm{N}-$ Nitrato & 1 e 2 & $2 \times$ semana & Método $-4110-\mathrm{B}$ \\
\hline Fósforo & 1 e 2 & $1 \times 15$ dias & Método 4500-P \\
\hline Série Completa de Sólidos & 1 e 2 & $2 \times$ semana & Método -2540 \\
\hline Alcalinidade & 1 e 2 & $2 \times$ semana & Método $-2320-\mathrm{B}$ \\
\hline pH & 1 e 2 & $2 \times$ dia & Método $-4500 \mathrm{H}^{+}-\mathrm{B}$ \\
\hline Temperatura & 1 e 2 & $2 \times$ dia & Método $-2550-\mathrm{B}$ \\
\hline
\end{tabular}

\subsubsection{Monitoramento do óxido nitroso no processo de lodos ativados}

A avaliação da emissão de óxido nitroso $\left(\mathrm{N}-\mathrm{N}_{2} \mathrm{O}\right)$ no tanque de aeração foi realizada durante 48 horas, durante dois dias consecutivos, em dois locais diferentes, conforme mostra a Figura 39. De acordo com a estratégia operacional para o desenvolvimento do processo de NDS a concentração de OD estava na faixa de 0,3 a $0,8 \mathrm{mgO}_{2} / \mathrm{L}$ e a taxa de fluxo de ar foi em medida em torno de $10.000 \mathrm{~m}^{3} / \mathrm{h}^{-1}$.

Figura 39: Pontos de amostragem de $\mathrm{N}_{2} \mathrm{O}$ no tanque de aeração

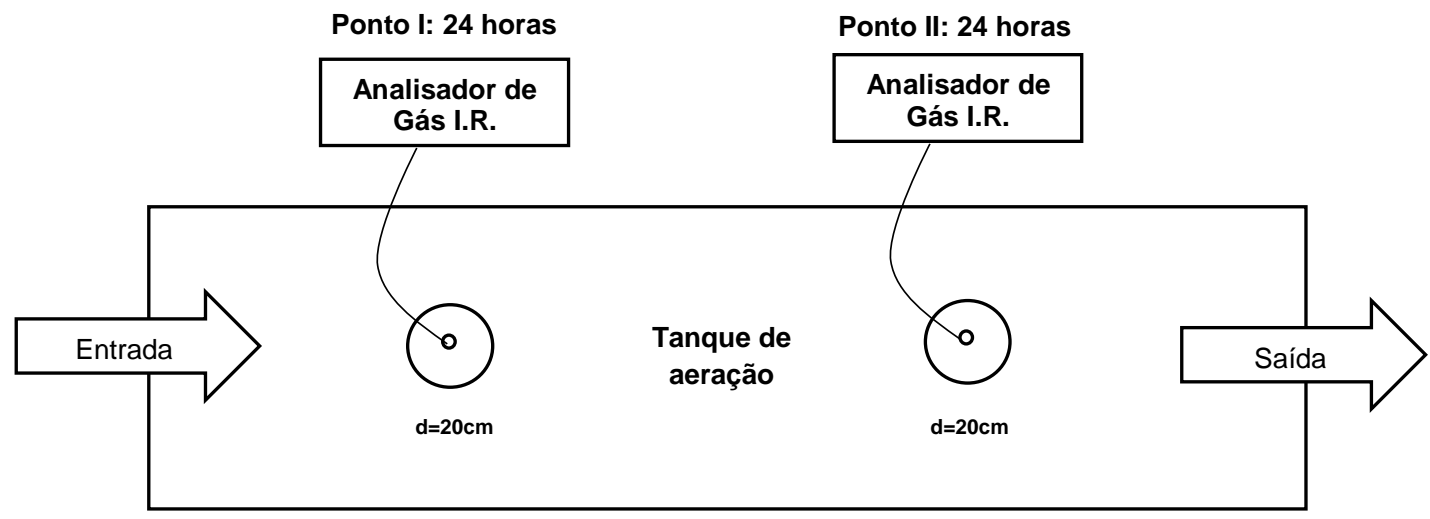


No tanque de aeração foi instalado uma câmara flutuante para o recolhimento do gás com área superficial de $0,05 \mathrm{~m}^{2}$, a amostragem de $\mathrm{N}_{2} \mathrm{O}$ no efluente gasoso retido na expansão da câmara era encaminhado para um analisador de gás de infravermelho modelo Los Gatos Research Inc., EUA, o fluxo de arraste foi controlado em 0,5 L.min1. A concentração de $\mathrm{N}_{2} \mathrm{O}$ foi registrada a cada segundo no período de 48 horas. $\mathrm{A}$ taxa de emissão de $\mathrm{N}_{2} \mathrm{O}$ foi calculado multiplicando a concentração $\Delta \mathrm{N}_{2} \mathrm{O}$ (diferença entre a concentração de $\mathrm{N}_{2} \mathrm{O}$ no ar retirado a partir da concentração de líquido e $\mathrm{N}_{2} \mathrm{O}$ no ar) com a vazão de ar (Q) medido in situ (de Mello et al., 2013; Rodriguez-Caballero et al., 2014) e com a relação de área entre a câmara flutuante e tanque de aeração (Alocal / Aaeração), como mostra a Eq. (54). A taxa de fluxo de ar foi medida por meio de rotâmetro digital.

$\mathrm{N}_{2} \mathrm{O}_{\text {taxa de emissão }}\left(\mathrm{g} \mathrm{N} \mathrm{h}^{-1}\right)=\Delta \mathrm{N}_{2} \mathrm{O}_{\text {concentraçăo }} \times \mathrm{Q} \times\left(\mathrm{A}_{\text {local }} \mathrm{A}_{\text {Tq.araçăo }}\right) \times(28 / 44)$

A Figura 40 mostra o cromatógrafo de infravermelho e a câmara flutuante utilizada para amostragem do gás.

Figura 40: Medidor infravermelho e câmara flutuante de amostragem de gás
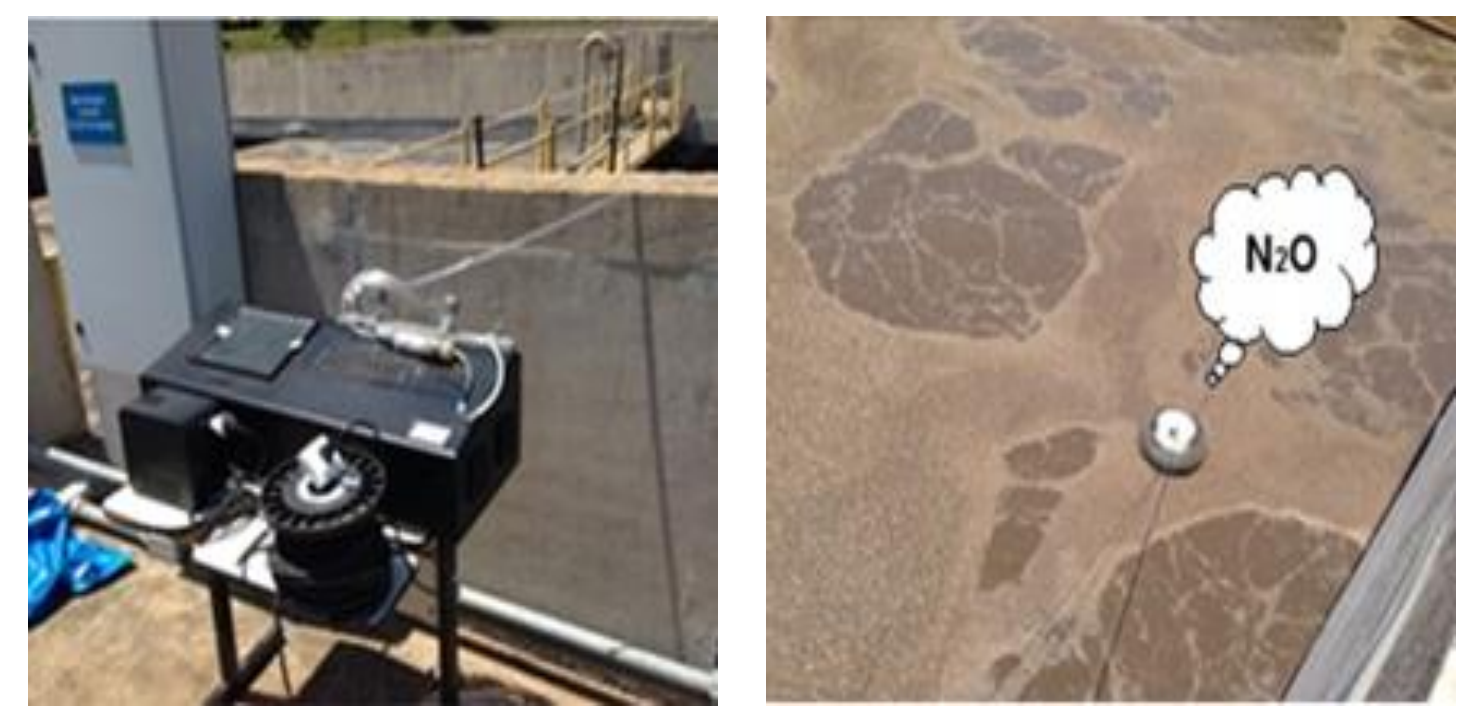


\subsubsection{Determinação das Características dos Lodos dos Reatores Biológicos}

Pontos de Amostragem:

Ponto 3: Lodo do tanque de aeração 1

Ponto 4: Lodo do tanque de aeração 2

Ponto 5: Lodo do tanque de aeração 3

\subsubsection{Variáveis Controladas, Pontos de Amostragem e Frequências}

As variáveis controladas nos lodos ativados e as frequências das análises laboratoriais são apresentadas na Tabela 9.

Tabela 9: Variáveis controladas nos lodos, pontos de amostragem e frequências

\begin{tabular}{l|c|c|c}
\hline \multicolumn{1}{c|}{ Variável } & $\begin{array}{c}\text { Pontos de } \\
\text { Amostragem }\end{array}$ & $\begin{array}{c}\text { Frequência das } \\
\text { Análises }\end{array}$ & Observações \\
\hline $\begin{array}{l}\text { Série Completa de Sólidos } \\
\begin{array}{l}\text { Sólidos Sedimentáveis 30 } \\
\text { minutos }\end{array}\end{array}$ & 3,4 e 5 & $2 \times$ semana & Método -2540 \\
\hline Oxigênio Dissolvido & 3,4 e 5 & $1 \times$ dia & Método -2540 \\
\hline pH & 3,4 e 5 & contínuo & LDO Hach \\
\hline Temperatura & 3,4 e 5 & contínuo & pH Hach \\
\hline $\begin{array}{l}\text { Potencial redox } \\
\text { Microbiologia } \\
\text { (microscopia) }\end{array}$ & 3,4 e 5 & contínuo & ORP Hach \\
\hline $\begin{array}{l}\text { Bactérias nitrificantes } \\
\text { Bactérias desnitrificantes }\end{array}$ & 3,4 e 5 & $1 \times$ semana & Marca Olympus CH-2 \\
\hline $\begin{array}{l}\text { Taxa de utilização de } 5 \\
\text { oxigênio (TCO) }\end{array}$ & 3,4 e 5 & $1 \times$ semana & Respirometria \\
\hline $\begin{array}{l}\text { Velocidade de } \\
\text { sedimentação }\end{array}$ & 3,4 e 5 & $1 \times$ semana & Respirometria \\
\hline
\end{tabular}

As determinações de concentração de oxigênio dissolvido nos lodos biológicos, pH, temperatura e potencial de óxido-redução formam determinados de forma contínua por meio de sensores instalados nos tanques de aeração. Todas as análises, exames 
e ensaios com os lodos dos tanques de aeração foram realizados nos três pontos nas regiões onde as sondas foram instaladas.

\subsubsection{Determinação da velocidade de sedimentação do lodo}

A velocidade de sedimentação da interface do lodo foi determinada experimentalmente através de testes em colunas de sedimentação acopladas a agitadores magnéticos, a metodologia foi adaptada de Von Sperling, 2002. O procedimento do teste teve as seguintes etapas:

- Colunas de vidro com diâmetro de $10 \mathrm{~cm}$ e altura de $50 \mathrm{~cm}$ (Figura 41);

- Homogeneização do lodo ativado através de mistura em todo o volume da coluna (agitação controlada entre 1 e 2 rpm);

- Após homogeinização do lodo foi desligado a agitação permitindo a sedimentação;

- Medição do nível da interface em intervalos de tempo pré-definidos;

- Término da medição quando o lodo não estiver mais sedimentando;

- Analisar os dados em forma gráfica (alturado da interface x tempo);

- Determinação da velocidade de sedimentação do lodo através da inclinação do trecho retilíneo do gráfico.

Figura 41: Aparato experimental utilizado nos testes de sedimentabilidade do lodo.

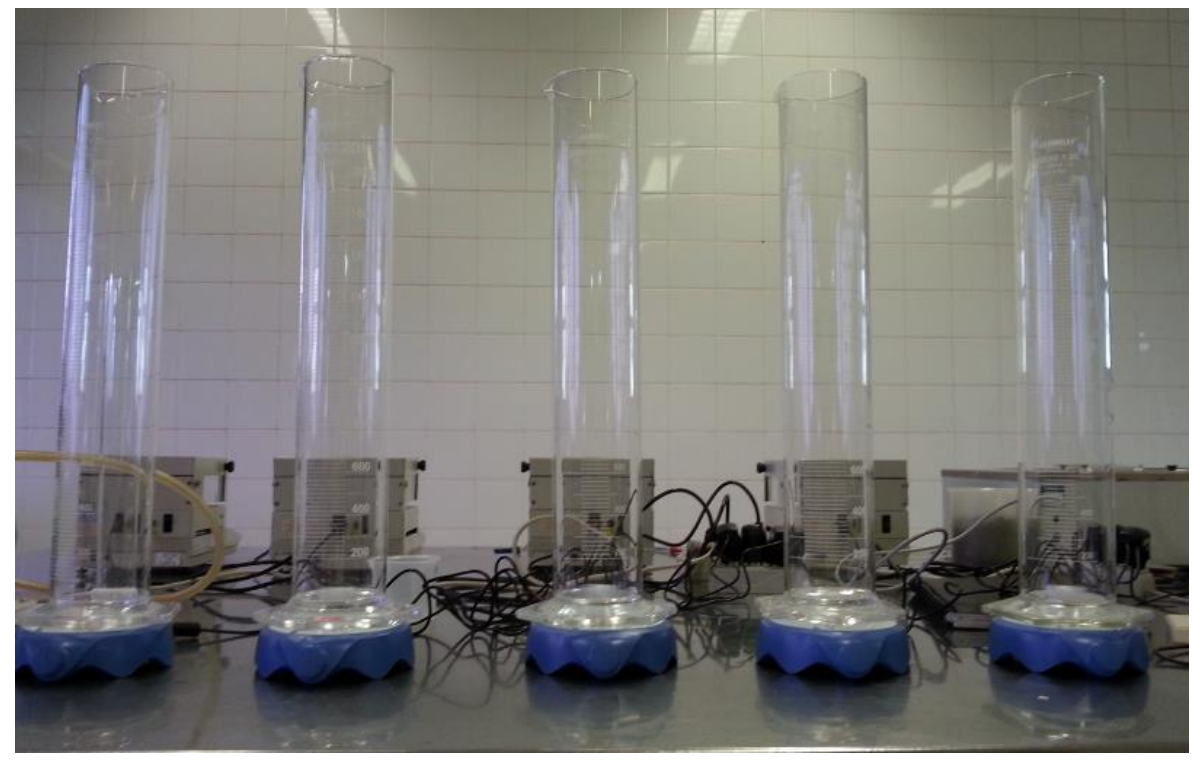


A velocidade de sedimentação $v$ é função da concentração de sólidos em suspensão $X$, decrescendo com o aumento de X. Há várias relações empíricas para expressar v em função de $X$, mas a mais frequentemente utilizada é:

$V=V_{0}^{*} e^{-k \cdot x}$

onde:

$\mathrm{v}=$ velocidade de sedimentação da interface na concentração $X(\mathrm{~m} / \mathrm{h})$

$X=$ concentração de sólidos em suspensão no lodo ativado $\left(\mathrm{kg} / \mathrm{m}^{3}\right)$

$\mathrm{V}_{\mathrm{o}}=$ coeficiente, expressando a velocidade de sedimentação da interface numa concentração $X=0(\mathrm{~m} / \mathrm{h})$

$\mathrm{K}=$ coeficiente de sedimentação $\left(\mathrm{m}^{3} / \mathrm{kg}\right)$

\subsubsection{Caracterização morfológica do floco de lodo ativado por meio de programas computacionais}

A metodologia adotada foi desenvolvida no laboratório de saneamento ambiental da Escola Politécnica da USP, o detalhamento da técnica assim como a validação do procedimento está descrito em Bueno, 2011. Resumidamente, se apresenta os passos para a determinação do diâmetro dos flocos de forma automática:

Coleta e preparação das amostras: Segundo Jenkins, et al. (2003), a elevada concentração de biomassa em processos de lodos ativados dificultam a observação visual do floco, sendo necessária a diluição das amostras para uma posterior análise. O autor recomenda uma quantidade de aproximadamente 20 flocos para observação visual. A diluição é importante também para a análise computadorizada da imagem, pois se deve evitar a aglomeração de partículas que exige do software o uso de ferramentas que as segmente, o que muitas vezes induz ao erro, uma vez que esta segmentação pode alterar a imagem original, aumentando-se, consequentemente, os erros referentes ao uso da técnica em estudo. O lodo estudado apresentava concentrações de sólidos totais na faixa de 2500 - 3500mg/L, nesse caso as diluições que permitiram uma boa visualização e a permanência de pelo menos 20 flocos no retículo foram as de 1:50, 1:70 e 1:100. Nesse caso nenhum floco ficou sobreposto e foi considerada adequada à captura de imagem. Utilizando a diluição estabelecida, 
um mililitro de amostra foi depositado em uma câmara de Sedgwick Rafter e levada ao microscópio óptico, com aumento de 40 vezes.

Processamento e análise das imagens: $O$ programa utilizado para o tratamento e obtenção das informações das imagens dos flocos do lodo ativado foi o Image $\mathrm{J}$ versão $1.45 \mathrm{~s}$. É um software gratuito de domínio público para processamento de imagem, desenvolvido pelo National Institutes of Health, USA, (Ferreira e Rasband, 2011). O programa permite o cálculo da área, distâncias, ângulos, diâmetros, entre outras funções que auxiliam na obtenção de dados de maneira mais rápida e precisa, se comparada ao método manual. Para que o programa ImageJ consiga identificar os flocos é necessário converter as imagens para a forma binária, isso é feito no próprio programa. As etapas básicas do processo aplicado são apresentadas na Figura 42, sendo que este pode ser automatizado, descartando a necessidade de se inserir comandos manuais para cada uma das etapas.

Figura 42: Fluxograma do processo básico de tratamento e dimensionamento das imagens para a quantificação e medição da geometria dos flocos.

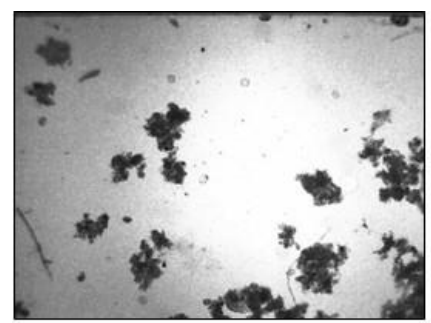

1. Abertura da imagem em 8 bit no ImageJ e inserção de escala.

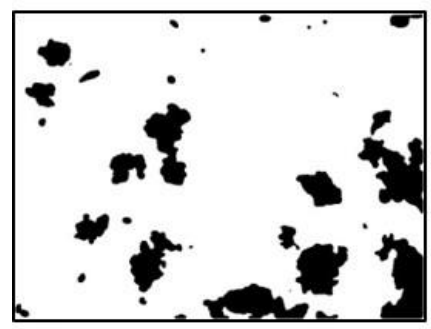

4. Remoção de resíduos e definição final dos flocos.
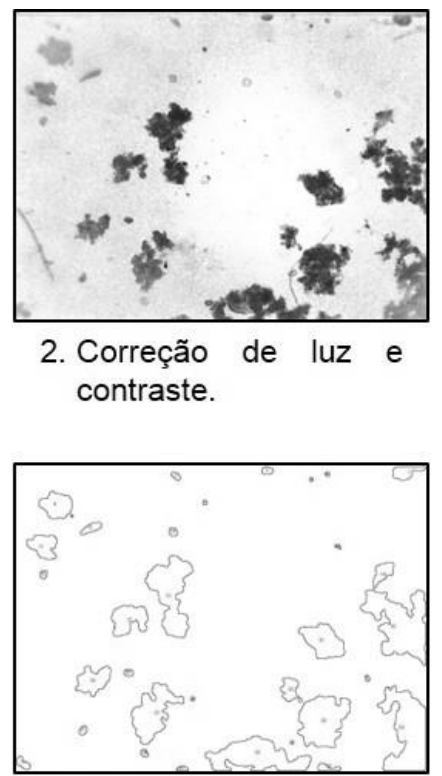

5. Dimensionamento dos flocos e geração de imagem com identificação numérica dos flocos.

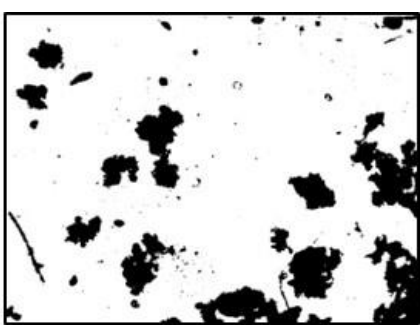

3. Passagem ao formato binário.

\begin{tabular}{|c|c|c|c|c|}
\hline \multicolumn{5}{|c|}{ Results } \\
\hline & Edit Font & Resul & & \\
\hline & Area & Perim. & Circ. & Feret \\
\hline & $4.277 \mathrm{E}-4$ & 0.092 & 0.630 & 0.041 \\
\hline & 0.006 & 0.414 & 0.418 & 0.159 \\
\hline & 0.002 & 0.192 & 0.814 & 0.075 \\
\hline & 0.006 & 0.637 & 0.187 & 0.181 \\
\hline & $1.555 \mathrm{E}-4$ & 0.042 & 1 & 0.018 \\
\hline
\end{tabular}

6. Geração de tabela com a identificação numérica dos flocos e os respectivos valores de seus parâmetros dimensionados.

A Figura 43 mostra um exemplo da imagem original dos flocos do lodo ativado reconhecidas pelo programa ImagemJ após tratamento. As tabelas geradas pelo 
ImageJ com os valores de diâmetro de Feret dos flocos dimensionados foram exportadas para o programa Microsoft $\Theta$ Excel$\circledast$ 2013, onde sofreram o tratamento estatístico.

Figura 43: Comparação entre as imagens originais e os flocos reconhecidos pelo Image J - A) lodo ativado aeração prolongada, B) lodo ativado convencional
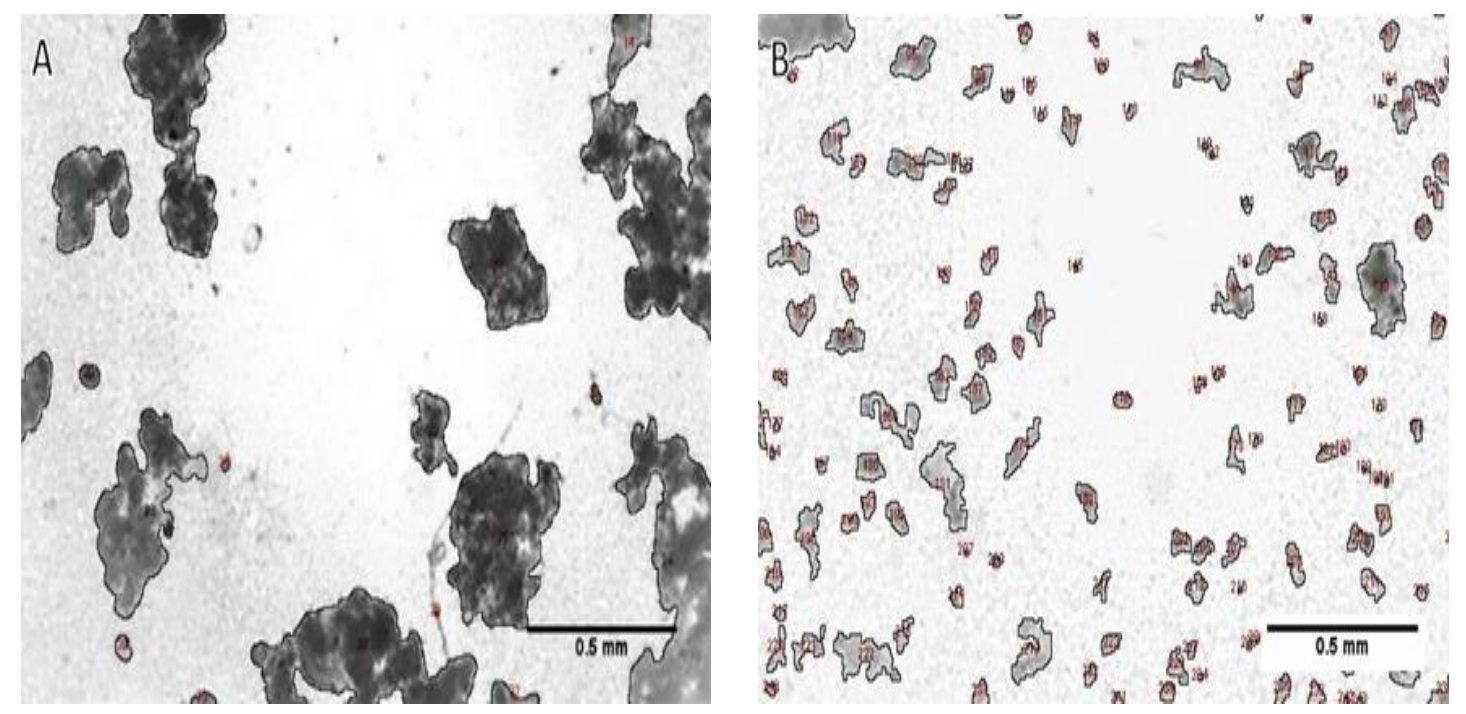

\subsubsection{Medição da TCO total "in loco" no processo de lodos ativados}

As determinações da TCO nos lodos ativados foram feitas online, por meio de medições de OD registradas em função do tempo, dentro da faixa de estudo $(0,3$ a 0,8 mg. $\left.\mathrm{L}^{-1}\right)$, ou seja, o OD inicial considerado para o teste foi $0,8 \mathrm{mg} \cdot \mathrm{L}^{-1} \mathrm{e}, \mathrm{em}$ seguida, quando a aeração era interrompida, os valores de OD foram registrados em função do tempo até que o valor de OD chegasse a uma concentração baixa $\left(0,3 \mathrm{mg} \cdot \mathrm{L}^{-1}\right)$ para, então, finalizar o teste e religar a aeração. Para o cálculo da TCO utilizou-se a equação 3.1. A TCO foi utilizada para monitorar a atividade metabólica do lodo e para calcular o balanço de massa.

Eq. (56)

$\mathrm{TCO}=\mathrm{dOD} / \mathrm{dt}=\left(\mathrm{OD}\right.$ máximo $\left.-O D_{\text {mínimo }}\right) /\left(\mathrm{t}_{1}-\mathrm{t}_{\mathrm{o}}\right)$ 


\subsubsection{Balanços de massa do material orgânico e nitrogenado}

\subsubsection{Balanço de massa do material orgânico}

Os cálculos do balanço de massa do material orgânico do sistema de lodo ativado por aeração prolongada foram realizados conforme descrito no item 3.8. As equações referentes ao balanço encontram-se na Tabela 10. O detalhamento de cada termo contido nessas equações está descrito na Lista de Símbolos. A Equação 57, possibilita a determinação de ( $\left.m S_{t e}\right)$ que é a massa de DQO detectada no efluente dos sistemas. Considerando os sistemas estudados em estado estacionário e, assim o valor de DQO determinado no efluente de cada sistema era equivalente ao material não biodegradável solúvel, já que somente esta fração da DQO poderia ter sido expulsa como efluente líquido. A Equação 58 apresenta a fração de DQO afluente que é descarregada com o lodo de excesso $\left(\mathrm{mS}_{\mathrm{xv}}\right)$. A Equação 59 expressa à fração de DQO afluente que é oxidada no sistema (mSo). Por fim, o balanço de massa do material orgânico para o sistema, $\left(\mathrm{B}_{\circ}\right)$, pode ser determinado através do uso da Equação 60.

Tabela 10: Equações utilizadas para determinação do balanço de massa do material orgânico

\begin{tabular}{lc}
\hline Equações para o balanço de massa do material orgânico & Equação \\
\hline$m S_{t e}=S_{t e} / S_{t a}$ & Eq. $(57)$ \\
\hline$m S_{x v}=\left(q / Q_{a}\right)^{*} f_{c v}{ }^{*} X_{v} / S_{t a}$ & Eq. (58) \\
\hline$m S_{0}=\left(V_{r} / Q_{a}\right)^{*} T C O_{c} / S_{t a}$ & Eq. (59) \\
\hline$B o=\left(M S_{t e}+M S_{x v}+M S_{o}\right)$ & Eq. (60) \\
\hline
\end{tabular}

\subsubsection{Balanço de massa do material nitrogenado}

Os cálculos do balanço de massa do material orgânico do sistema de lodo ativado por aeração prolongada foram realizados conforme no item 3.9. As equações referentes ao sistema encontram-se na Tabela 11. O detalhamento de cada termo contido nessas equações está descrito na Lista de Símbolos. A Equação 61 possibilita a determinação do fluxo de material nitrogenado no lodo de excesso ( $\left.\mathrm{MN} \mathrm{N}_{\mathrm{I}}\right)$. A Equação 62 e 63 possibilitam a determinação do fluxo de material nitrogenado afluente $\left(\mathrm{MN}_{\mathrm{ta}}\right)$ 
e efluente $\left(\mathrm{MN}_{\mathrm{te}}\right)$ do sistema de lodo ativado. O fluxo de material nitrogenado desnitrificado no sistema pode ser determinado pela Equação 64. Por fim, o balanço de massa do material nitrogenado para o sistema de lodo ativado $\left(B_{n}\right)$, pode ser determinado através do uso da Equação 65.

Tabela 11: Equações utilizadas para determinação do balanço de massa do material nitrogenado

\begin{tabular}{lc}
\hline \multicolumn{1}{c}{ Equações para o balanço de massa do material nitrogenado } & Equação \\
\hline $\mathrm{MN}_{\mathrm{l}}=\mathrm{f}_{\mathrm{n}}{ }^{*} \mathrm{~V}_{\mathrm{r}}{ }^{*} \mathrm{X}_{\mathrm{v}} / \mathrm{R}_{\mathrm{s}}$ & Eq. (61) \\
\hline $\mathrm{MN}_{\mathrm{ta}}=\mathrm{Q}_{\mathrm{a}}{ }^{*}\left(\mathrm{~N}_{\mathrm{oa}}+\mathrm{N}_{\mathrm{aa}}+\mathrm{N}_{\mathrm{na}}\right)=\mathrm{Q}_{\mathrm{a}}{ }^{*} \mathrm{~N}_{\mathrm{ta}}$ & Eq. (62) \\
\hline $\mathrm{MN}_{\mathrm{te}}=\mathrm{Q}_{\mathrm{a}}{ }^{*}\left(\mathrm{~N}_{\mathrm{oe}}+\mathrm{N}_{\mathrm{ae}}+\mathrm{N}_{\mathrm{ne}}\right)=\mathrm{Q}_{\mathrm{a}}{ }^{*} \mathrm{~N}_{\mathrm{te}}$ & Eq. (63) \\
\hline $\mathrm{MN}_{\mathrm{d}}=\left(\mathrm{Q}_{\mathrm{a}}+\mathrm{q}\right)^{*} \Delta \mathrm{N}_{\mathrm{n}}$ & Eq. (64) \\
\hline $\mathrm{B}_{\mathrm{n}}=\left(\mathrm{MN} \mathrm{N}_{\mathrm{l}}+\mathrm{MN} \mathrm{N}_{\mathrm{te}}+\mathrm{MN} \mathrm{N}_{\mathrm{d}}\right) / \mathrm{MN} \mathrm{N}_{\mathrm{ta}}$ & Eq. (65) \\
\hline
\end{tabular}

\subsubsection{Uso da Respirometria para determinação das constantes cinéticas da nitrificação}

Para a determinação das taxas de consumo de oxigênio (TCO), usou-se um respirômetro modelo Beluga do tipo aberto acoplado a um aerador e um agitador para medições de forma semi-contínua, ligados a um computador e controlado através do software S4.0C, (Figura 44). A concentração de OD foi estabelecida na faixa de 0,3 a 0,8 $\mathrm{mg} \cdot \mathrm{L}^{-1}$, reproduzindo as mesmas condições de operação da ETE Limoeiro promovendo a NDS. Foi possível manter essa baixa concentração de OD sem erros de leitura, pois o respirômetro foi configurado para ligar a aeração quando a concentração de $O D$ era menor que o limite de referência inferior $\left(0,3 \mathrm{mg} \cdot \mathrm{L}^{-1}\right)$, aumentando a concentração de OD. Quando esta chegava ao valor de referência superior $\left(0,8 \mathrm{mg} \cdot \mathrm{L}^{-1}\right)$, a aeração era interrompida e observava-se a diminuição da concentração de OD devido a respiração. Ao atingir novamente o valor de referência inferior, a aeração era ligada novamente e iniciava-se outro ciclo. Desta maneira determinava-se a TCO semi-continuamente (VAN HAANDEL e CATUNDA, 1982), como é possível observar no respirograma de OD e TCO na Figura 45. Os dados de TCO, OD e temperatura foram registrados através do software em arquivos do Excel. 
Figura 44: Respirômetro do tipo aberto e semi-contínuo

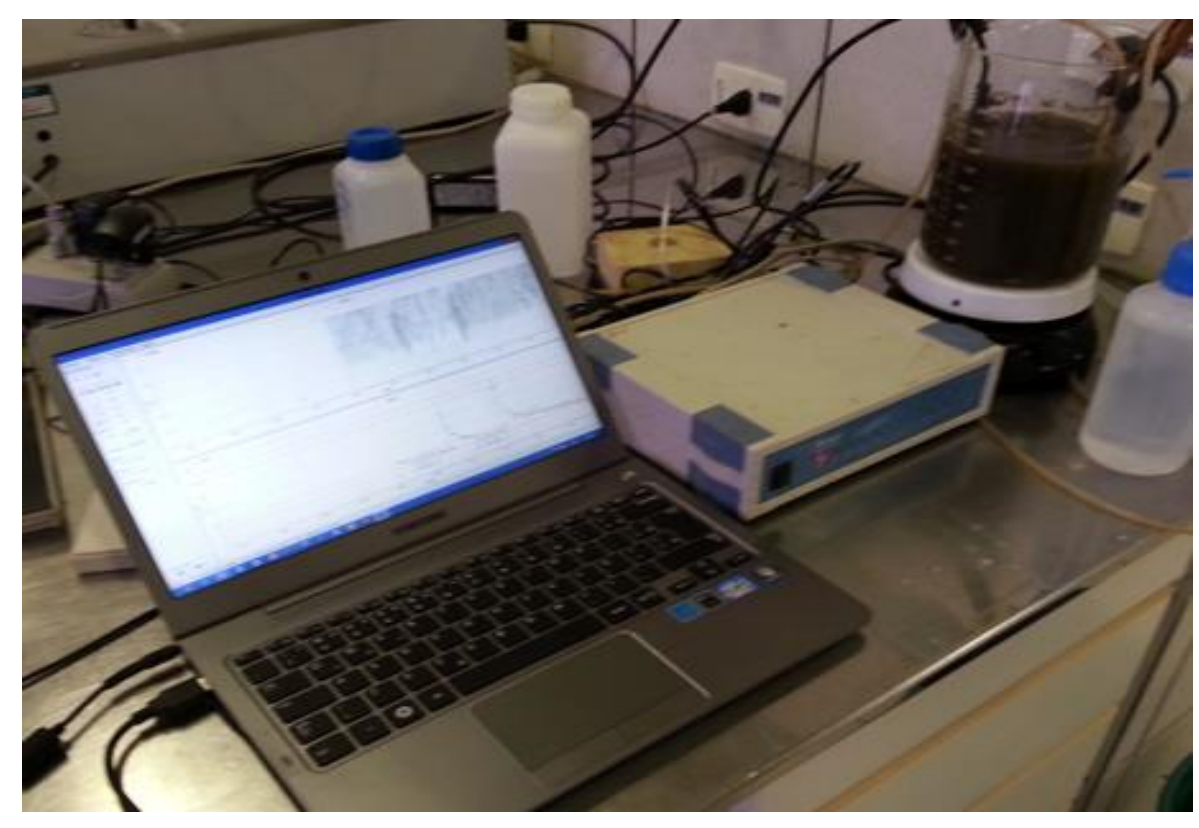

Figura 45: Respirograma experimental com medições de OD na faixa de $(0,3-0,8$ mg.L-1) e TCO endógena.

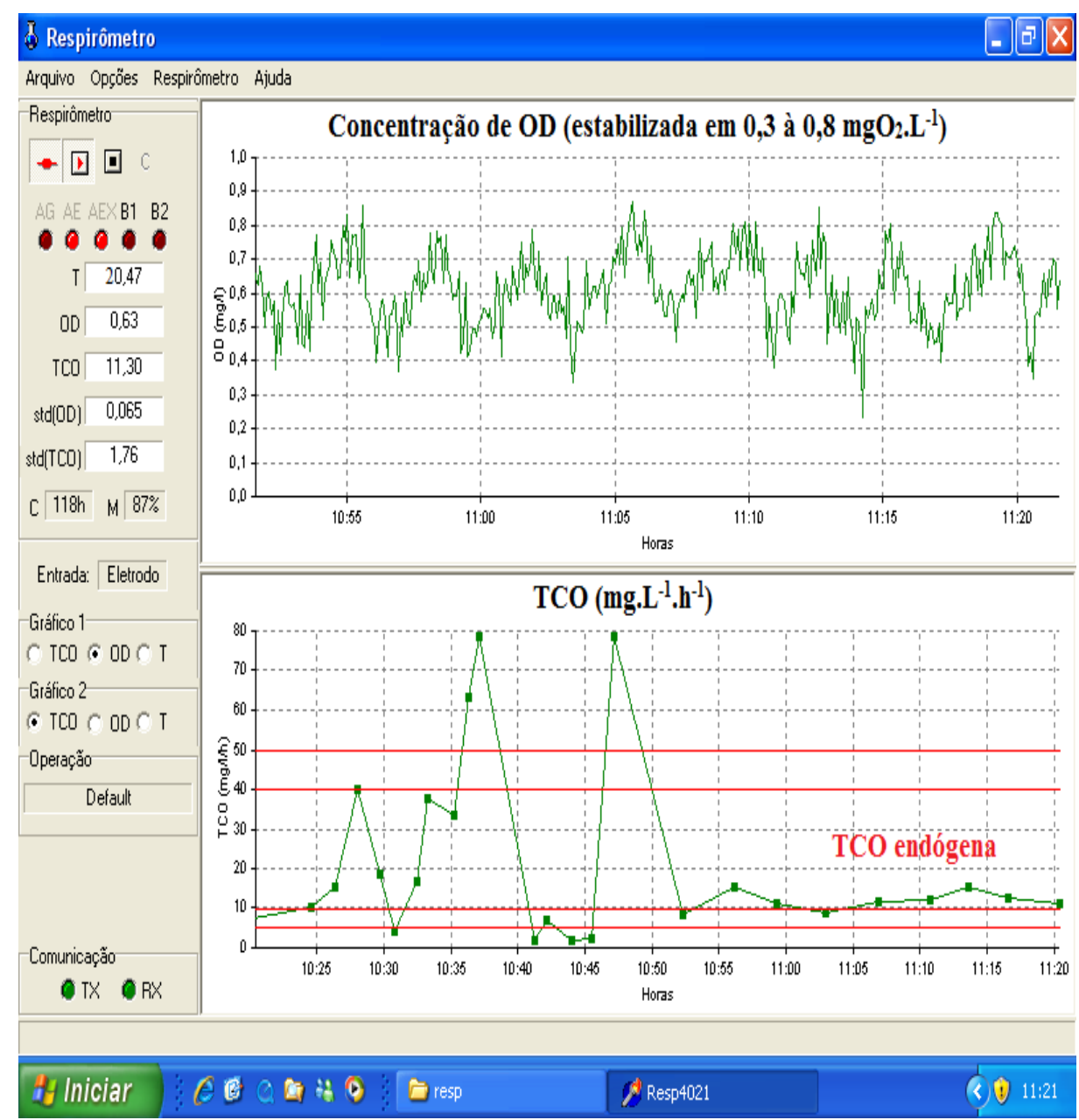


Com o intuito de minimizar a influência de possível transferência do gás oxigênio atmosférico para a massa líquida empregada no teste, foi desenvolvido um pequeno reator com tampa e abertura para introdução da sonda, hélice de agitação e aeradores. Ressalta-se que a hélice utilizada para promover a mistura do lodo foi feita de plástico a fim de não causar ruído no sinal da sonda para o equipamento. A Figura 46 ilustra todo o aparato empregado no teste.

Figura 46: Reator utilizado nos testes respirométricos, (a) reator e haste para mistura, (b) sistema montado para realização do teste.

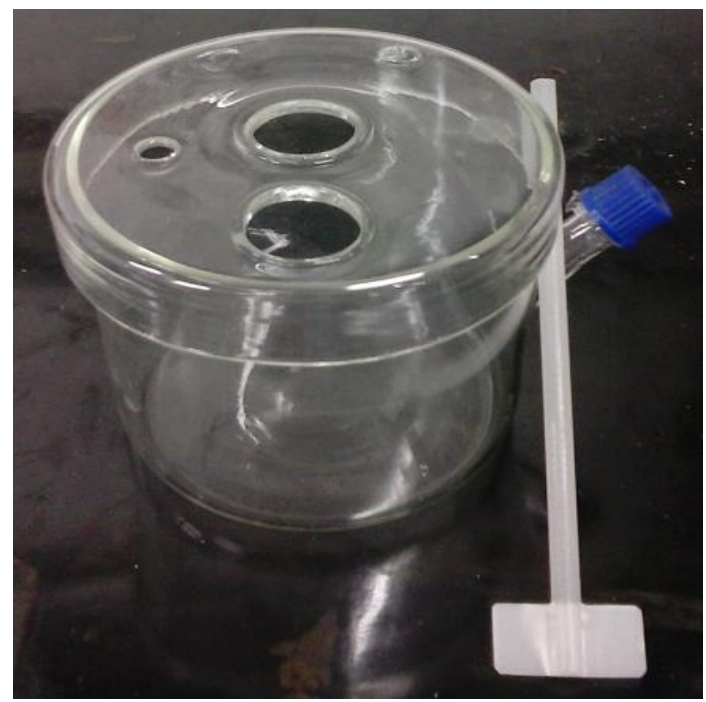

(a)

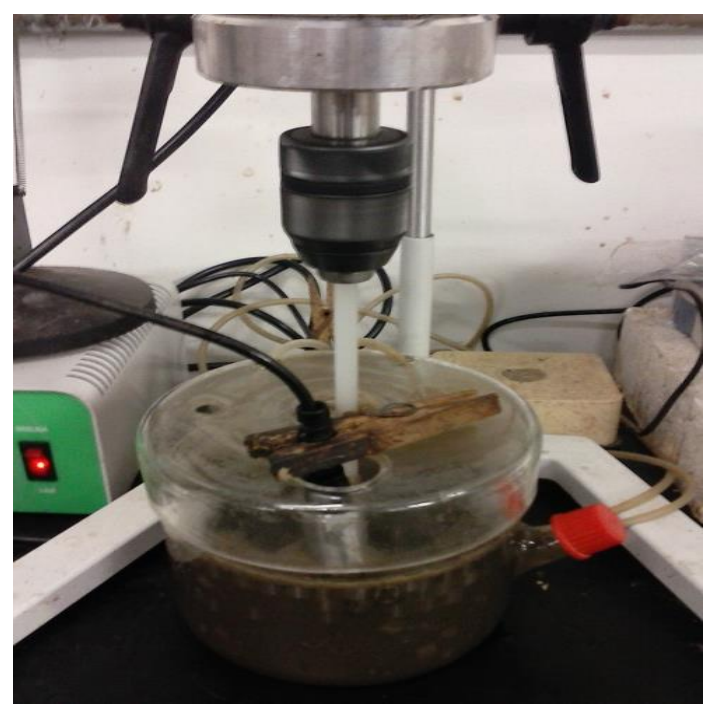

(b)

\subsubsection{Investigação experimental da atividade bacteriana autotrófica}

Para realização dos testes respirométricos e avaliação da atividade das bactérias autotróficas no processo de lodos ativados, foram utilizados substratos específicos para cada grupo de bactérias. O consumo de substrato adicionado era traduzido pelo consumo de OD, registrado pelo respirômetro, calculando também a TCO. Os substratos utilizados para os grupos de bactérias de interesse nesse estudo são apresentados na Tabela 12. 
Tabela 12: Substratos para os testes respirométricos com bactérias autotróficas nitrificantes

\begin{tabular}{ccc}
\hline Grupo de bactéria & Substrato Específico & Oxidante \\
\hline Bactérias autotróficas nitritadoras & Cloreto de Amônio $\left(\mathrm{NH}_{4} \mathrm{Cl}\right)$ & Oxigênio \\
\hline Bactérias autotróficas nitratadoras & Nitrito de Sódio $\left(\mathrm{NaNO}_{2}\right)$ & Oxigênio \\
\hline
\end{tabular}

A seguir, detalha-se a metodologia empregada para realização do teste:

- Inicialmente liga-se o respirômetro e aguarda-se 10 minutos para então se calibrar o eletrodo de oxigênio com o valor de saturação da temperatura ambiente e altitude local;

- Retira-se uma alíquota (2 litros) do lodo ativado do tanque de aeração, o processo deve estar sob condições estacionárias, desenvolvendo a nitrificação. Esta alíquota será submetida à agitação e aeração controlada (condições previamente configuradas no respirômetro), afim de que todo substrato extracelular disponível no lodo seja utilizado, estabelecendo uma TCO mínima e constante correspondente à respiração endógena (TCO endógena);

- Estabelecida a respiração endógena, a alíquota será separada em duas partes sendo 1 litro utilizado para análises de caracterização físico-químicas, como controle sem adição de substrato, e a outra alíquota (1 litro) efetivamente para o teste; deve-se realizar a determinação da alcalinidade do meio e, caso necessário, a adição externa (solução de $\mathrm{NaHCO}_{3}$ ) com o intuito de que tal variável não seja limitante para o processo;

- Após atingir a TCO endógena será adicionado o substrato específico (Cloreto de Amônia ou Nitrito de Sódio). Deve-se adicionar uma quantidade suficiente de substrato para que o mesmo não seja limitante do processo (substrato $>>K_{s}$ ), permitindo que a nitritação ou nitratação se desenvolva sob taxa máxima;

- Determina-se então a TCO em função do tempo, inicialmente tendo-se uma TCO alta e constante (TCO máxima ou exógena), correspondente à taxa máxima de nitrificação; 
- A TCO permanecerá alta até que se conclua o consumo do substrato, observando-se então uma repentina diminuição, até que se obtenha o valor que existia antes da adição, ou seja, da TCO endógena;

- Ainda, em paralelo, para efeito de controle, foram retiradas alíquotas do lodo $(10 \mathrm{~mL}$ ) durante o teste com intervalos de 10 minutos e logo em seguida adicionado sulfato de mercúrio para inibição das atividades biológicas. As alíquotas foram ser centrifugadas por 15 minutos à $3500 \mathrm{rpm}$, e o sobrenadante foi utilizado para a determinação de amônia, nitrito e nitrato em função do tempo.

A taxa de utilização máxima de amônia ( $r_{n}$.nitritante) e de nitrito ( $\left.r_{\text {n.nitratante) }}\right)$ podem ser obtidas com o emprego das Equações (31) e (32) descritas na seção X, e, de posse desses valores, obter suas respectivas taxas máximas de crescimento $(\mu \max )$, com base na Equação (30) na mesma seção. Dentro do mesmo teste é possível, ainda, determinar a constante de meia saturação $\left(K_{n}\right)$, cujo valor é igual à concentração do substrato quando $1 / 2 \mu=\mu_{\max }$ ou $T C O_{n}=1 / 2 T C O_{n}$.máx. A importância dessa constante se deve ao fato de que quando a TCO começa a decrescer, o substrato (amônia ou nitrito) torna-se um fator limitante para o crescimento das bactérias nitrificantes.

A seguir, apresenta-se a metodologia utilizada.

- Após um teste respirométrico onde se adicionou um substrato de amônia ou nitrito, com uma concentração conhecida, obte-se um respirograma;

- Através do respirograma e dos dados armazenados no Excel, determina-se o momento em que a $\mathrm{TCO}_{n}$ é metade da máxima $\left(\mathrm{TCO}_{n}=1 / 2 \mathrm{TCO}\right.$.máx $)$;

- Após determinar a $\mathrm{TCO}_{\mathrm{n}}$, determina-se a área hachurada que corresponde ao substrato residual em $\left(\mathrm{mgO} . \mathrm{L}^{-1}\right)$, através da soma de trapézios;

- Por fim, calcula-se a concentração do substrato amônia ou nitrito, como a razão do valor da área hachurada pelos respectivos coeficientes estequiométricos de oxigênio por mol do substrato considerado $\left(K_{n}=\right.$ amônia $/ 4,57$ e $K_{n}=$ nitrito $/ 1,14)$.

$\mathrm{Na}$ Figura 47, podem-se observar o comportamento de um respirograma genérico durante a adição de um substrato solúvel a uma batelada de lodo e, na Figura 48 um 
respirograma experimental obtido neste estudo, onde foi adicionado uma concentração de amônia como substrato (10mgN.L-1).

Figura 47: Respirograma genérico da adição de um substrato solúvel a uma batelada de lodo ativado

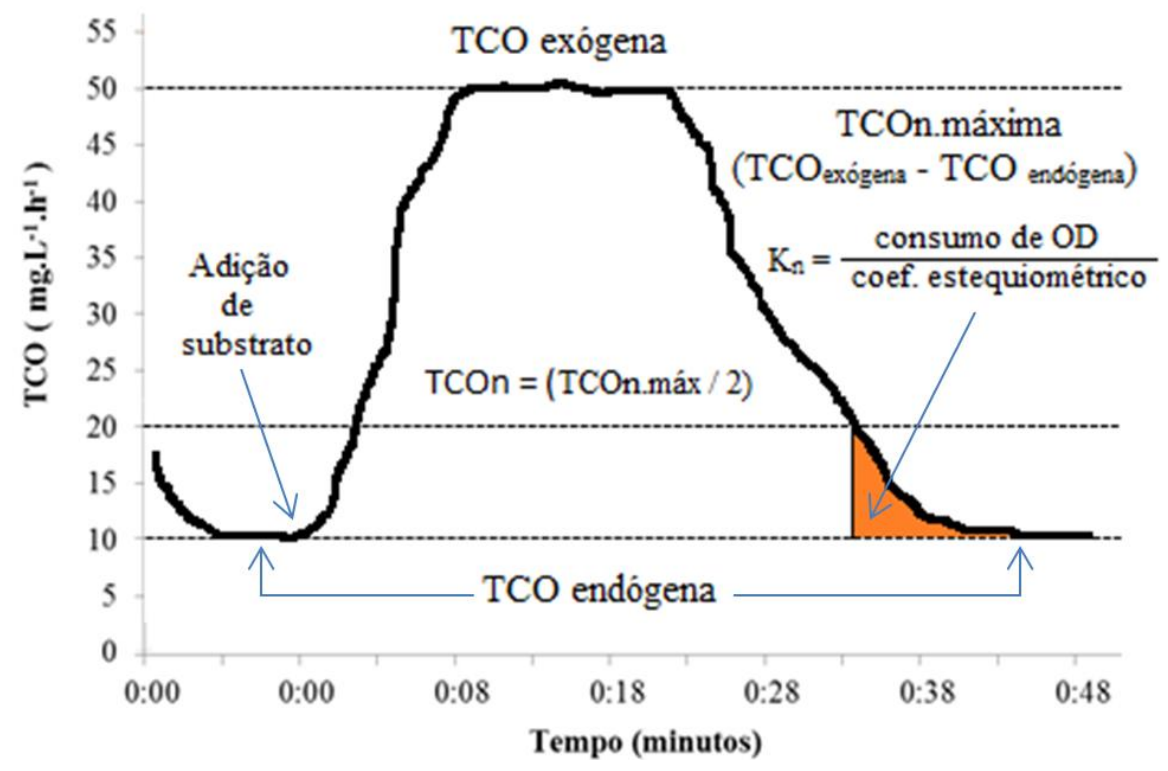

Figura 48: Exemplo de um respirograma experimental com adição de amônia como substrato em uma batelada de lodo ativado

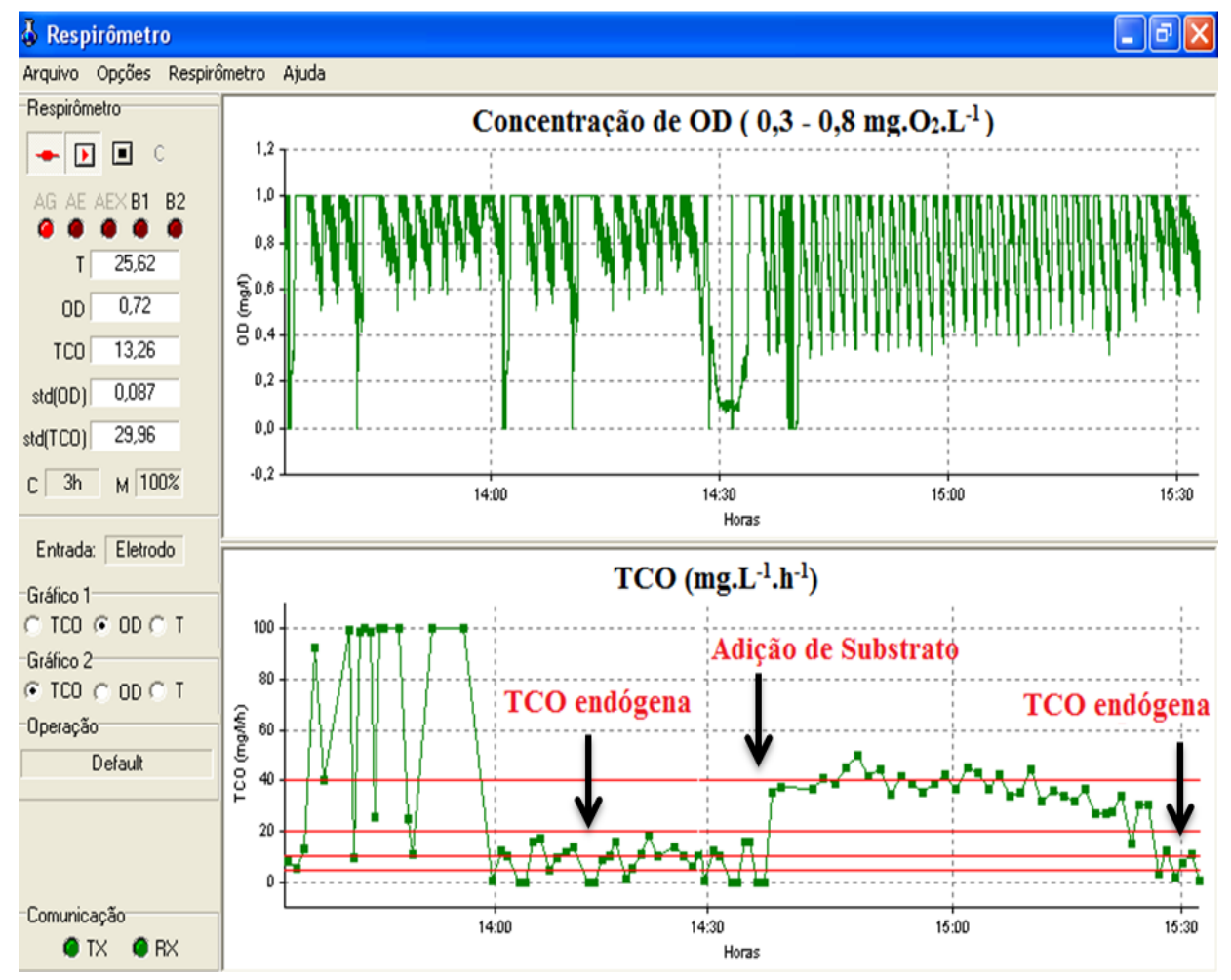




\subsubsection{Estimativa das constantes de crescimento específico $(\mu \mathrm{m})$, constante de}

meia saturação de Monod $(\mathrm{Kn})$ e da taxa máxima de nitritação e nitratação (rn.max).

\section{Constante de crescimento específico máximo $\left(\mu_{\mathrm{m}}\right)$}

Para determinar a taxa específica de crescimento " $\mu \mathrm{m}$ " foi utilizada a equação de Monod, Equação (66) (Monod, 1949).

$\mu \mathrm{m}=\mu$ máx $[S /(S+K s)]$

\section{Sendo:}

$\mu_{m}$ : taxa específica de crescimento $\left(\mathrm{d}^{-1}\right)$;

Hmáx: taxa específica máxima de crescimento $\left(\mathrm{d}^{-1}\right)$;

Ks: constante de meia saturação ( $\mathrm{K}_{n}$ para as nitrificantes ou nitratadoras);

S: concentração de substrato.

Observa-se que se a quantidade de substrato adicionada é muito grande ( $\mathrm{S}>\mathrm{Ks}$ ), o valor de $\mu \mathrm{m}$ é igual ao valor de $\mu$ máx, sendo $\mu$ máx determinado através da respirometria, conforme a Equação 67 (VAN HAANDEL E MARAIS,1999).

$\mu_{\text {máx }}=\left(Y^{*} r_{\text {máx }}\right) / X$

Sendo:

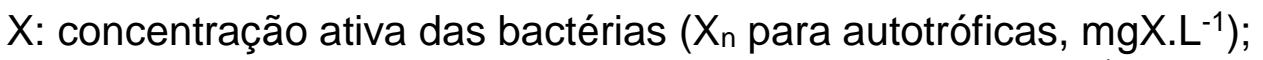

$\mathrm{Y}$ : coeficiente de rendimento das bactérias $\left(0,1 \mathrm{mgX}_{\mathrm{n}} \cdot \mathrm{mgN}^{-1}\right.$ para autotróficas);

rmáx: taxa máxima de consumo do substrato $\left(\mathrm{mgS} \cdot \mathrm{L}^{-1} \cdot \mathrm{h}^{-1}\right)$, determinada através da TCO.

Conforme a cinética de Monod, a concentração de bactérias autotróficas pode ser calculada a partir dos dados dos valores analíticos obtidos nas análises físicoquímicas (VAN HAANDEL e MARAIS,1999). Para constante de decaimento $\left(b_{n}\right)$ foi adotado um valor típico de 0,04(1,13)(T-20), sugerido por EKAMA \& MARAIS (1976).

$\mathrm{X}_{\mathrm{n}}=\mathrm{Y}_{\mathrm{n}} \mathrm{R}_{\mathrm{s}} \mathrm{N}_{\mathrm{c}} /\left(1+\mathrm{b}_{\mathrm{n}} \mathrm{R}_{\mathrm{s}}\right) \mathrm{R}_{\mathrm{h}}$

Onde: 
$Y_{n}$ : coeficiente de rendimento das bactérias nitrificantes $\left(0,10 \mathrm{mgN}^{-1}\right)$

$X_{n}$ : a concentração das bactérias autotróficas $\left(\mathrm{mgX}_{\mathrm{n}} \mathrm{L}^{-1}\right)$

$\mathrm{N}_{\mathrm{c}}$ : a concentração de amônia nitrificada (mgN. $\left.\mathrm{L}^{-1}\right)$

$\mathrm{R}_{\mathrm{s}}$ : a idade de lodo $\left(\mathrm{d}^{-1}\right)$

Rh: o tempo de permanência $\left(d^{-1}\right)$

$b_{n}$ : a constante de decaimento $\left(b n=0,04(1,03)^{(t-20)}(\right.$ VAN HAANDEL e MARAIS, 1999)

$\mathrm{t}$ : a temperatura $\left({ }^{\circ} \mathrm{C}\right)$

Onde se tem que:

$\mathrm{N}_{\mathrm{c}}=\mathrm{NTK}_{\mathrm{a}}-\mathrm{NTK}_{\mathrm{e}}-\mathrm{N}$

A concentração de amônia nitrificada ( $\mathrm{Nc}$ ) se calculou como a diferença entre a concentração do Nitrogênio Total Kejdhal (NTK) afluente e efluente do sistema, subtraindo-se a concentração de nitrogênio necessário para a produção de lodo, onde a fração de nitrogênio no lodo é de aproximadamente 0,1 (COURA, 2002; DERKS; 2007). Sendo Nı determinado conforme a Equação 69:

$\mathrm{N} I=f_{n} X_{v} V_{r} / R_{s} Q_{a}$

Onde:

Ni é a concentração de nitrogênio necessário para a produção de lodo (mgN.L-1) $f_{n}$ é a fração de lodo volátil que é nitrogênio (10\%)

$X_{v}$ é a concentração de lodo volátil $\left(\mathrm{mgN}_{\mathrm{L}} \mathrm{L}^{-1}\right)$

$V_{r}$ é o volume dos reatores do sistema de tratamento $\left(L^{-1}\right)$

$Q_{a}$ é a vazão afluente $\left(L^{-d^{-1}}\right)$

Por outro lado, a TCO máxima da nitrificação das nitritadoras ou nitratadoras (TCOn.máx) é obtida através dos dados do respirômetro como:

$\mathrm{TCO}_{\text {n.máx }}=\mathrm{TCO}_{\text {exo,máx }}-\mathrm{TCO}_{\text {end }}$

Onde:

TCOexo,máx é a taxa de consumo de oxigênio exógena máxima $\left(m g \cdot \mathrm{L}^{-1} \mathrm{~h}^{-1}\right)$ TCOn.máx é a taxa de consumo de oxigênio máxima para nitritação ou nitratação (mg.L$\left.{ }^{1} h^{-1}\right)$

TCO end é a taxa de consumo de oxigênio endógena $\left(\mathrm{mg} \cdot \mathrm{L}^{-1} \mathrm{~h}^{-1}\right)$ 
Assim, conforme a teoria de lodo ativado (VAN HAANDEL e MARAIS,1999), pode-se calcular a taxa máxima de nitritação ou nitratação como se segue:

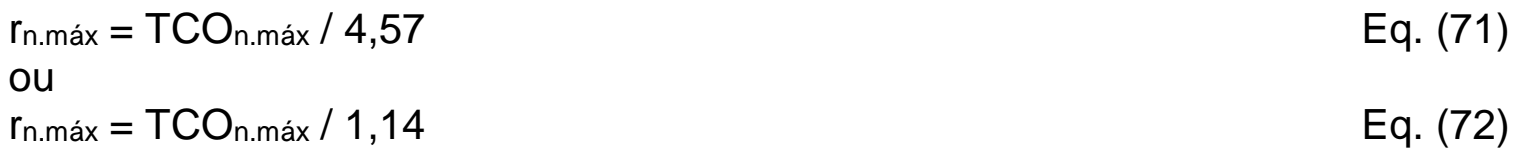

OU

$r_{\text {n.máx }}=$ TCOn.máx $/ 1,14$

Sendo:

TCOn.máx: TCO total devido à nitrificação $\left(\mathrm{mg} \cdot \mathrm{L}^{-1} \cdot \mathrm{h}^{-1}\right)$;

rn.máx: taxa de utilização máxima de amônia $\left(\mathrm{mgNH}_{4} \cdot \mathrm{mgX}_{\mathrm{n}} \cdot \mathrm{d}^{-1}\right)$;

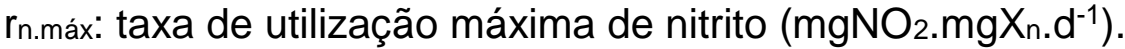

Os denominadores 4,57 e 1,14 da Equação 71 e 72 respectivamente dão o consumo estequiométrico de oxigênio por mol do substrato considerado (amônia e nitrito, respectivamente).

Agora se pode determinar a constante $(\mu \mathrm{m})$ usando a Equação 73 , sendo:

$\mu_{m}=\left(Y_{n}^{*} r_{n \cdot m a ́ x}\right) / X_{n}$

Constante de meia saturação de amônia e nitrito $(\mathrm{Kn})$

Como se pode observar na Figura 47 e 48, quando a TCO começa a decrescer, o substrato (amônia ou nitrito) torna-se um fator limitante para o crescimento das bactérias nitrificantes. De acordo com a cinética de Monod, para estimar o valor da constante de meia saturação $\left(K_{n}\right)$ para nitritantes ou nitratantes, deve-se determinar a concentração de substrato no momento em que $\mu$ for $=1 / 2 \mu$ máx, ou que a TCOn $=$

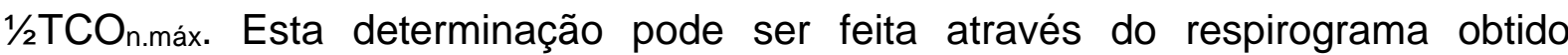
conforme a metodologia descrita no item 4.3.8.1 sendo realizada da seguinte maneira:

(1) Após um teste respirométrico realizado conforme o item 4.3.8.1, onde se adicionou um substrato de amônia ou nitrito, com uma concentração conhecida, obtemos um respirograma; 
(2) Através do respirograma e dos dados armazenados no Excel, determina-se o momento em que a $\mathrm{TCO}_{n}$ é metade da máxima $\left(\mathrm{TCO}_{\mathrm{n}}=1 / 2 \mathrm{TCO}\right.$.máx);

(3) Após determinar a TCOn, determina-se a área hachurada que corresponde ao substrato residual em (mgO.L $\left.{ }^{-1}\right)$, através da soma de trapézios.

(4) E por fim calcula-se a concentração do substrato amônia ou nitrito, como a razão do valor da área hachurada pelos respectivos coeficientes estequiométricos de oxigênio por mol do substrato considerado ( $\mathrm{K}_{\mathrm{n}}=$ amônia /4,57 e $K_{n}=$ nitrito /1,14).

\subsubsection{Frações biodegradáveis de matéria orgânica do esgoto sanitário}

Para a determinação das frações biodegradáveis da matéria orgânica do esgoto sanitário, foram realizados testes respirométricos, conforme o procedimento descrito anteriormente, com os passos adicionais seguintes:

(1) Após a sedimentação do lodo foi sifonado o sobrenadante, o volume sifonado foi completado com esgoto sanitário afluente;

(2) Antes de ser iniciada a aeração do conteúdo do béquer foram adicionados 10 $\mathrm{mg} \cdot \mathrm{L}^{-1}$ de uma solução de alil-tiouréia para inibir a atividade das bactérias autotróficas;

(3) O teste foi realizado, sendo controlado pelo respirômetro que mantinha a concentração de OD no intervalo adotado;

$\mathrm{Na}$ Figura 49, podem-se observar um respirograma experimental onde se vê na janela inferior o gráfico da TCO, expressa em mgO. $\mathrm{L}^{-1} \cdot \mathrm{h}^{-1}$. Identificam-se nesse gráfico, logo no começo do teste, a utilização do material biodegradável e solúvel e, portanto, rapidamente biodegradável e a do material biodegradável e particulado (que apresenta valor em declínio) e a TCO endógena que representa o valor medido mais baixo e constante do gráfico. As áreas definidas entre a respiração exógena e 
endógena dão o valor da $\mathrm{DQO}$ utilizada e, assim, determinam-se as frações biodegradáveis do esgoto.

Figura 49: Respirograma experimental da determinação das frações do material orgânico.

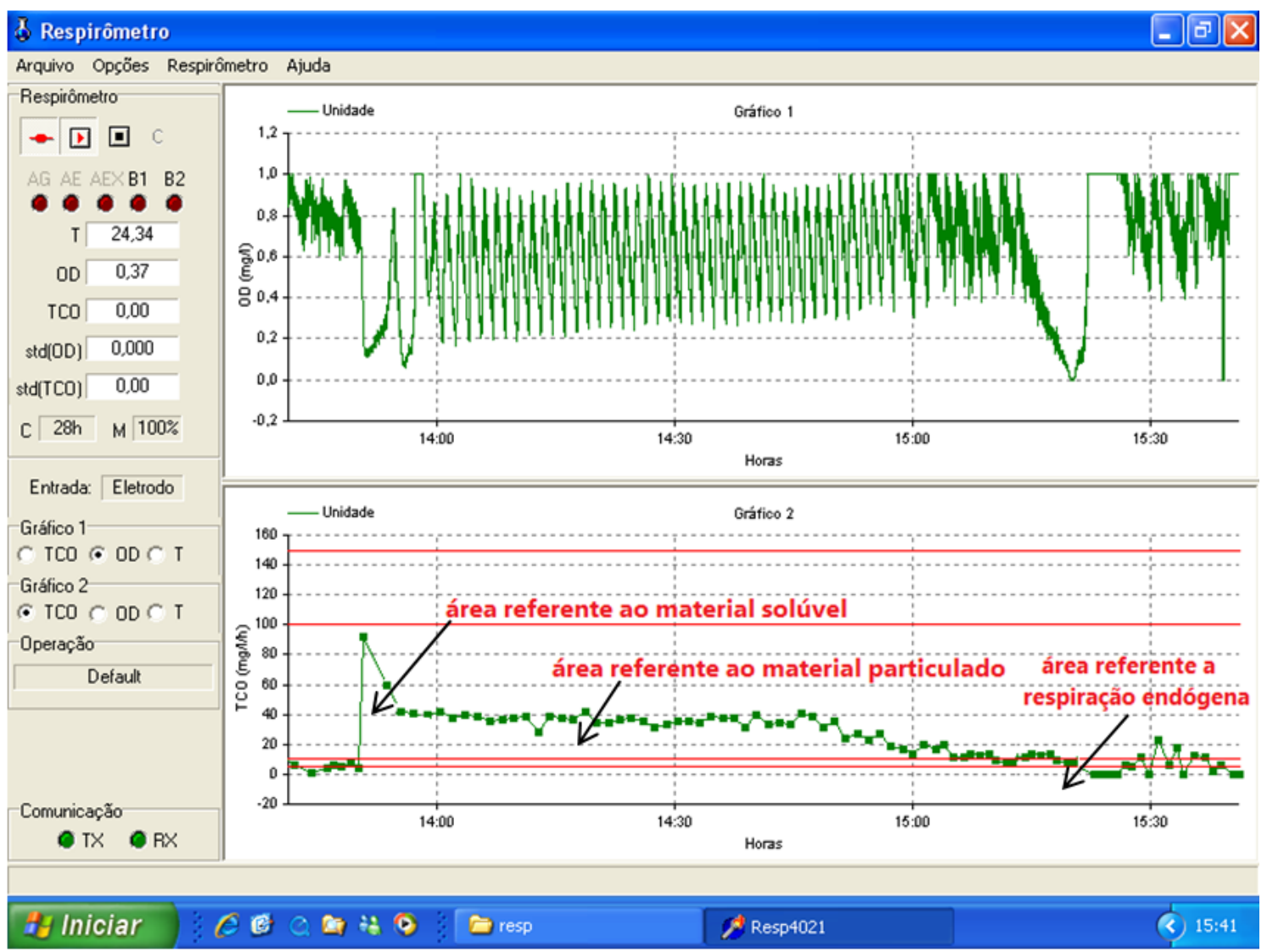

Segundo a teoria de lodo ativado (VAN HAANDEL e MARAIS, 1999) quanto à composição do material orgânico do afluente, a fração não biodegradável e solúvel (fus) pode ser calculada a partir dos valores da concentração da DQO no efluente e no afluente conforme a Equação 74:

$f_{\text {us }}=S_{\text {te }} / S_{\text {ta }}$

A fração não biodegradável e particulada (fup) pode ser calculada a partir da concentração de lodo volátil (que é a soma da concentração de lodo ativo $\left(\mathrm{X}_{\mathrm{a}}\right)$, resíduo endógeno $\left(\mathrm{X}_{\mathrm{e}}\right)$ e lodo inerte $\left.\left(\mathrm{X}_{\mathrm{i}}\right)\right)$. Segundo Van Haandel e Marais: 
A fração biodegradável e solúvel (fbs) pode ser determinada com auxílio da Respirometria. Já a determinação da DQO biodegradável afluente ao sistema (Sba) foi determinada segundo a Equação 76 .

$S_{\text {ba }}=\left(1-f_{\text {us }}-f_{\text {up }}\right) * S_{\text {ta }}$

\subsubsection{Investigação experimental da atividade bacteriana heterotrófica}

Com uso da respirometria e determinações analíticas realizou-se uma investigação experimental para comparar a taxa de oxidação de material orgânico tendo como oxidante o oxigênio dissolvido e o nitrato em ambiente com baixa concentração de $O D$ (0,3-0,8 $\left.\mathrm{mgL}^{-1}\right)$ promovendo a NDS. Para tanto, usou-se bateladas do licor misto do sistema de lodo ativado. Destas bateladas foram determinadas a TCO e a TCO equivalente (via nitrato) com material orgânico solúvel (acetato de sódio), simulando uma DQO rapidamente biodegradável e com substrato particulado (suspensão de amido comercial) simulando uma DQO lentamente biodegradável e com o próprio esgoto sanitário afluente. Nos testes de TCO equivalente foi adicionado uma concentração de $10 \mathrm{mgN} \cdot \mathrm{L}^{-1}$ de nitrato de potássio. Os testes foram realizados conforme a metodologia descrita a seguir:

(1) Após o estabelecimento da TCO endógena (conforme descrito na seção 4.3.81), mantinha-se a aeração na faixa de $\left(0,3-0,8 \mathrm{mg}^{-\mathrm{L}^{-1}}\right)$, para promover a NDS;

(2) Verificou-se a TCO referente ao consumo endógeno. Em seguida era adicionada uma concentração de material orgânico como: acetato de sódio, amido ou esgoto sanitário, equivalente a (100 mg. $\mathrm{L}^{-1}$ de DQO).

Após a determinação da TCO endógena inicial, calcula-se a concentração de lodo ativo (Xa) pela Equação 3.5.1 (VAN HAANDEL e MARAIS, 1999):

$\mathrm{TCO}_{\text {end }}=f_{\mathrm{cv}}(1-f){ }^{*} \mathrm{~b}_{n} X_{\mathrm{a}}$

Eq. (77) 
Onde:

TCOend: taxa de consumo de oxigênio para respiração endógena;

$f_{\mathrm{cv}}$ : fator de conversão de sólidos voláteis em DQO;

f: fração de lodo ativo que ao decair permanece como resíduo endógeno $=0,2$;

bn: constante de decaimento de lodo ativo $=0,24(1,04)^{(T-20)}$;

Xa: concentração de lodo ativo.

\subsubsection{Caracterização dos grupos de microrganismos atuantes no processo por Biologia Molecular - FISH}

Os grupos microbianos responsáveis pelos processos de nitrificação e desnitrificação que ocorrem nos lodos ativados foram identificados por meio da técnica FISH. Foi possível identificar grupos microbianos presentes no lodo como bactérias nitritantes, nitratantes e desnitrificantes. Nessa técnica, sondas oligonucleotídicas foram utilizadas para identificar os organismos específicos de modo qualitativo. A Tabela 13 apresenta algumas das sondas que foram empregadas nesse estudo.

Tabela 13: Sondas oligonucleotídicas e os grupos microbianos alvo.

\begin{tabular}{c|c|c|c}
\hline Sonda & Sequência (5'-3') & Grupo alvo & Referência \\
\hline Nso 1225 & CGC CAT TGT ATT ACG TGT GA & Nitritantes & Mobarry et al. (1996) \\
\hline Nit3 & CCT GTG CTC CAT GCT CCG & Nitratantes & Mobarry et al. (1996) \\
\hline Pae997 & TCTGGAAAGTTCTCAGCA & Desnitrificantes & Daims et al. (1999) \\
\hline
\end{tabular}

As análises de biologia molecular foram realizadas no laboratório do departamento de saúde e saneamento ambiental da fundação Oswaldo Cruz do Rio de Janeiro. O detalhamento do procedimento analítico está descrito em Mabub, 2010.

\subsection{Estação de tratamento de esgoto em escala piloto}

Apesar da otimização do sistema de lodos ativados em escala real e de um controle operacional rigoroso no período de estudo, houve ocasiões de limitações nas retiradas de lodo de excesso que junto às variações de vazão de esgoto à entrada da ETE dificultou o controle da idade do lodo no sistema, essas dificuldades acarretaram em determinados períodos um esgoto tratado com concentrações de sólidos superiores 
aos encontrados em processos de lodos ativados com aeração prolongada. Nesse caso, foi oportuno a implantação de uma estação de tratamento em escala piloto em paralelo a ETE em escala real. A ETE piloto foi operada sob as mesmas condições do processo de lodos ativados de modo a promover o processo de NDS. A manutenção da aeração no tanque de aeração foi feita por meio de uma válvula solenoide controlada por um medidor de oxigênio dissolvido (OD) da marca Prominet. O sistema de aeração foi de ar difuso e o fornecimento de ar era feito por compressor. A concentração de OD foi mantida na faixa de 0,3 a $0,8 \mathrm{mg} \cdot \mathrm{L}^{-1}$, similar ao da escala real. O volume útil do tanque de aeração foi de 500 Litros. A concentração de $\mathrm{OD}, \mathrm{pH}$, temperatura e potencial de oxidação-redução (ORP), foram medidos e monitorados durante todo o estudo, por meio de sensores instalados no tanque de aeração. Os dados foram registrados em um computador, por um data logger. A Figura 50 mostra o arranjo experimental da ETE piloto implantada no local da ETE Limoeiro.

Figura 50: Corte esquemático do sistema de lodo ativado com sensores de medição online

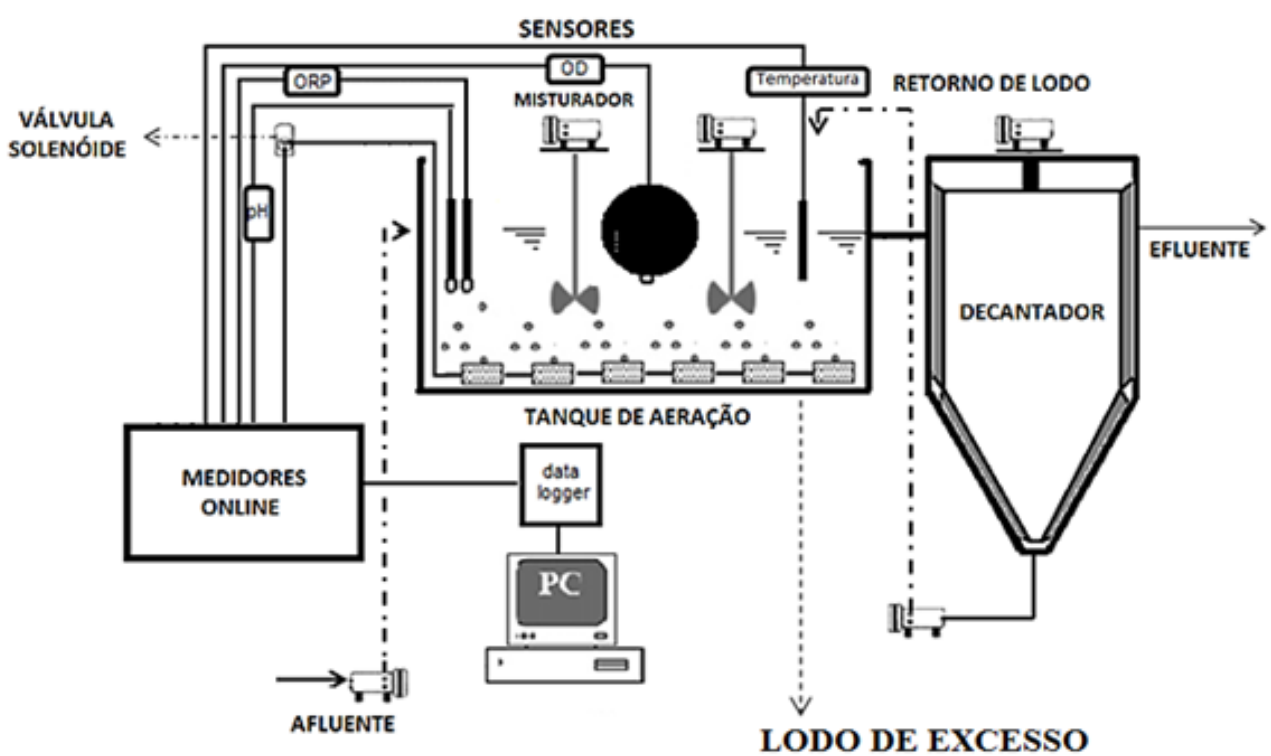

O controle da vazão de esgoto à entrada do processo de lodos ativados e a vazão de retorno de lodo para o tanque de aeração foram feitos por meio de bombas da marca Netzsch, tipo NEMO, com capacidade máxima de bombeamento de 150L/h. A vazão foi controlada por meio de inversores de frequência. Para efeito de controle da idade do lodo, era descartado diariamente um volume de lodo de excesso a partir da linha de retorno da ETE piloto. Esse volume era ajustado continuamente em função dos 
resultados das análises laboratoriais para determinação das variáveis envolvidas. $\mathrm{Na}$ Equação (53) apresenta a fórmula utilizada.

$Q_{w}=\frac{\left[V_{r} * X_{v}-\left(R_{S} * Q_{\text {total }} * X_{e}\right)\right]}{R_{S} *\left(X_{r}-X_{e}\right)}$

Sendo que:

$Q_{w}=$ vazão de descarte de lodo $\left(\mathrm{m}^{3} \cdot \mathrm{d}^{-1}\right)$;

$X_{e}=$ sólidos em suspensão voláteis no efluente $\left(\mathrm{mg} \mathrm{L}^{-1}\right)$;

$\mathrm{X}_{\mathrm{r}}=$ sólidos em suspensão voláteis no lodo de retorno $\left(\mathrm{mg}^{\mathrm{L}} \mathrm{L}^{-1}\right)$.

A Figura 51 mostra a imagem da ETE Piloto implantada no local do estudo, durante o estudo foi necessário revestir a piloto com material escuro para evitar a formação de algas devido a alta incidencia de luz no local. O controle operacional e as determinações análiticas foram as mesmas realizadas em escala real, apresentadas anteriormente.

Figura 51: ETE piloto implantada no local da pesquisa

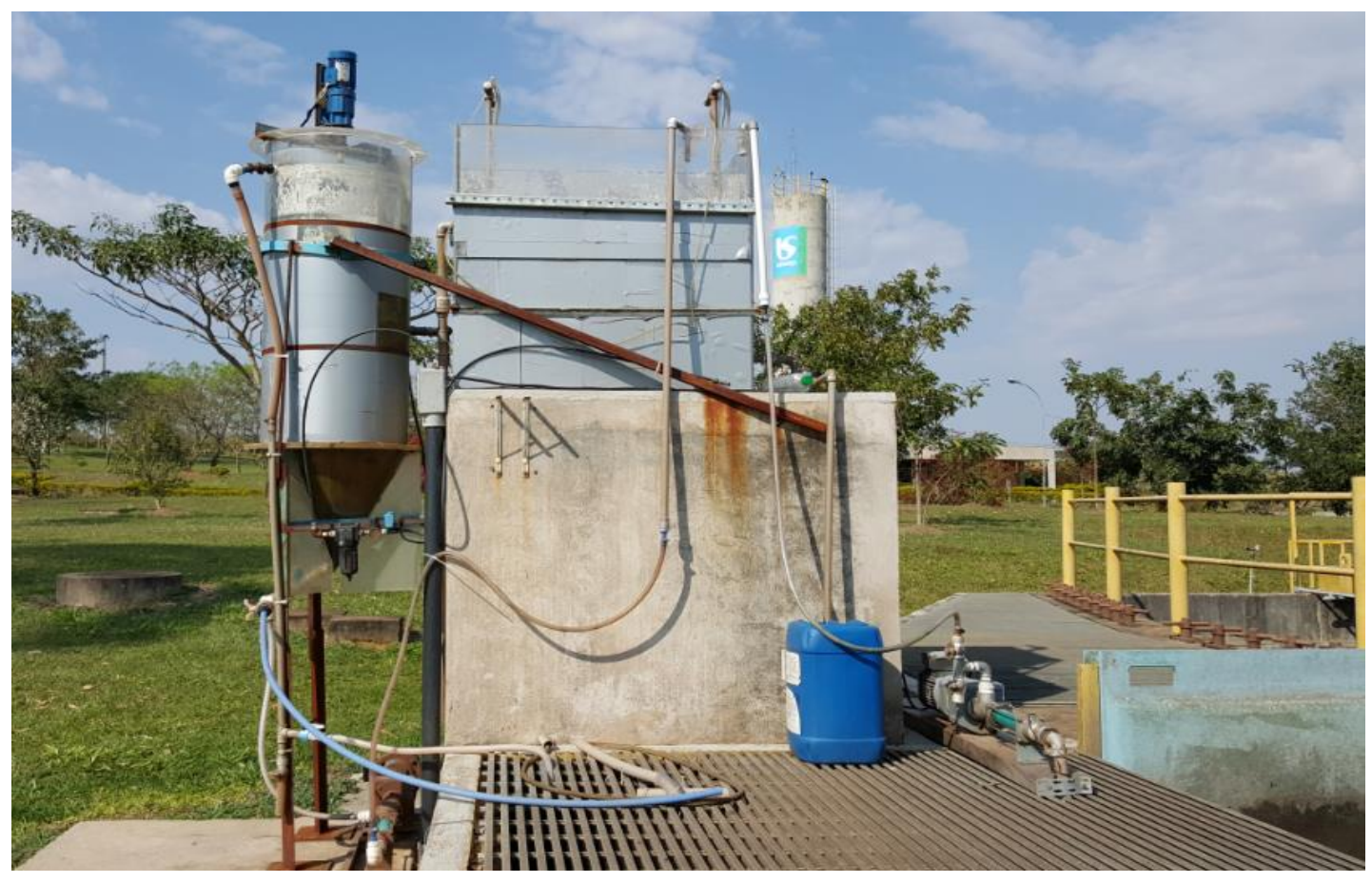




\section{APRESENTAÇÃO DOS RESULTADOS E DISCUSSÕES}

\subsection{Introdução}

Neste item são apresentados os resultados obtidos experimentalmente durante o período de 2012 a 2015 do estudo, considerando-se os parâmetros de interesse para o processo de nitrificação e desnitrificação simultânea e o desempenho do sistema.

\subsection{CONTROLE LABORATORIAL E MONITORAMENTO ONLINE DAS PRINCIPAIS VARIÁVEIS EXERCIDAS NO PROCESSO DE LODO ATIVADO}

\subsubsection{Vazão de esgoto da ETE Limoeiro}

Os dados de vazão do esgoto à entrada e saída do processo de lodos ativados foram obtidos por meio de medições online durante todo o estudo e são apresentados nas Tabelas 14 e 15, respectivamente.

Tabela 14: Vazão de esgoto afluente ao processo de lodos ativados

\begin{tabular}{c|c|c|c|c}
\hline \multicolumn{5}{c}{ Vazão afluente (L/s) } \\
\hline Variável & 2012 & 2013 & 2014 & 2015 \\
\hline Média & 430 & 470 & 466 & 475 \\
\hline Máximo & 641 & 722 & 618 & 713 \\
\hline Mínimo & 146 & 341 & 254 & 318 \\
\hline DP & 67 & 51 & 47 & 49 \\
\hline CV (\%) & 16 & 11 & 10 & 10 \\
\hline $\mathrm{N}$ & 203 & 365 & 365 & 365 \\
\hline
\end{tabular}

Tabela 15: Vazão de esgoto efluente ao processo de lodos ativados

\begin{tabular}{c|c|c|c|c}
\hline \multicolumn{5}{c}{ Vazão efluente (L/s) } \\
\hline Variável & 2012 & 2013 & 2014 & 2015 \\
\hline Média & 373 & 398 & 426 & 435 \\
\hline Máximo & 695 & 654 & 615 & 699 \\
\hline Mínimo & 256 & 270 & 319 & 305 \\
\hline DP & 65 & 55 & 48 & 50 \\
\hline CV $(\%)$ & 17 & 14 & 11 & 12 \\
\hline $\mathrm{N}$ & 305 & 365 & 365 & 365 \\
\hline
\end{tabular}


Na Tabela 14 observa-se a ocorrência de acréscimo da vazão afluente do ano de 2012 a 2013, de 430 L/s em média para 470 L/s, motivado pela implantação de novos trechos de rede coletora de esgoto. Nos demais anos não há diferença significativa permanecendo em uma vazão média de 470 L/s. Ao comparar os resultados das Tabelas 14 e 15, não foi possível obter uma justificativa plausível para as diferenças entre as vazões de entrada e saída, ambas determinadas por meio de sensores online instalados sobre medidor Parshall, com leituras ao longo das 24 horas diárias. A vazão de descarte do lodo ativado em excesso é de menor magnitude em relação às diferenças observadas. Com os dados do monitoramento online de vazão, construímos a Figura 52, onde se observa a mediana, os quartis (inferior e superior) e a dispersão dos dados das vazões durante todo o período de estudo. Nota-se, mais uma vez que não houve diferença significativa na mediana dos anos de 2013 a 2015.

Figura 52: Diagramas Box-Whiskers das vazões afluente e efluente - ETE LimoeiroSabesp

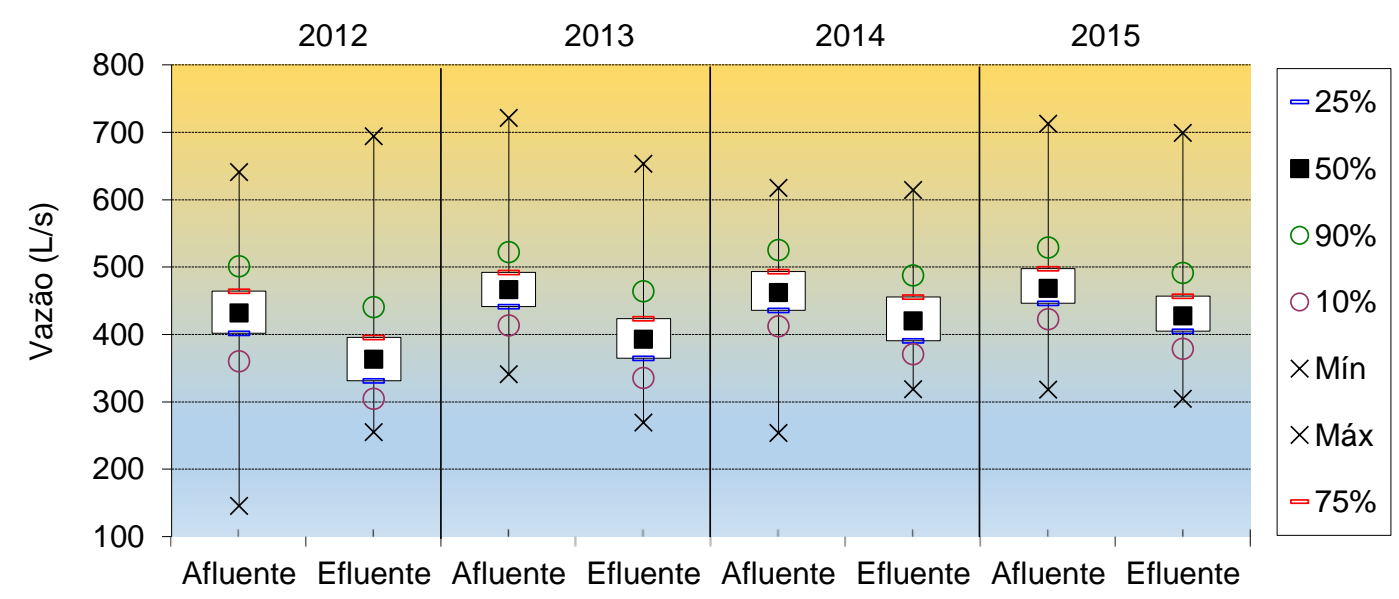

No ano de 2012, compondo-se a vazão média com a $\mathrm{DBO}_{5}$ do esgoto afluente de 353 $\mathrm{mg} / \mathrm{L}$ e com a DQO de $729 \mathrm{mg} / \mathrm{L}$, tem-se a carga de DBO afluente à ETE no período de $13.115 \mathrm{~kg} / \mathrm{dia}$ e a carga de DQO de $27.084 \mathrm{~kg} / \mathrm{dia}$. No ano de 2013, a DBO5 do afluente resultou em $356 \mathrm{mg} / \mathrm{L}$, enquanto que a DQO resultou $753 \mathrm{mg} / \mathrm{L}$, compondo as cargas respectivas de $14.456 \mathrm{kgDBO} / \mathrm{dia}$ e de $30.578 \mathrm{kgDQO} / \mathrm{dia}$. No ano de 2014, a $\mathrm{DBO}_{5}$ do afluente resultou em $345 \mathrm{mg} / \mathrm{L}$, enquanto que a DQO resultou $772 \mathrm{mg} / \mathrm{L}$, compondo as cargas respectivas de $13.891 \mathrm{kgDBO} / \mathrm{dia}$ e de $31.083 \mathrm{kgDQO} / \mathrm{dia}$ e no ano de 2015, a $\mathrm{DBO}_{5}$ do afluente resultou em $345 \mathrm{mg} / \mathrm{L}$, enquanto que a DQO resultou 
$708 \mathrm{mg} / \mathrm{L}$, compondo as cargas respectivas de $13.891 \mathrm{kgDBO} / \mathrm{dia}$ e de 29.056 kgDQO/dia. A Tabela 16 mostra o resumo das cargas orgânicas tratadas durante o estudo.

Tabela 16: Resumo das cargas orgânicas tratadas no período de 2012 a 2015 na ETE Limoeiro - SABESP.

\begin{tabular}{c|c|c|c|c}
\hline Carga & 2012 & 2013 & 2014 & 2015 \\
\hline $\mathrm{kgDBO} / \mathrm{dia}$ & 13.115 & 14.456 & 13.891 & 14.159 \\
\hline $\mathrm{kgDQO} / \mathrm{dia}$ & 27.084 & 30.578 & 31.083 & 29.056 \\
\hline
\end{tabular}

\subsubsection{Concentrações de sólidos nos tanques de aeração no processo de lodos ativados}

Conforme apresentado no item 4 (materiais e métodos), a ETE Limoeiro possui 03 tanques de aeração que foram operados sob condições similares durante todo o estudo. Em decorrência da carga orgânica afluente e do controle exercido sobre a idade do lodo, as concentrações de sólidos em suspensão totais e voláteis resultantes nos tanques de aeração são apresentadas nas Tabelas 17 e 18. Ainda, com os dados das determinações da série de sólidos, construímos a Figura 53, onde observa-se a mediana, os quartis (inferior e superior) e a dispersão dos dados obtidos durante o período de estudo.

Tabela 17: Sólidos em suspensão nos tanques de aeração (2012 e 2013)

\begin{tabular}{c|c|c|c|c|c|c}
\hline \multicolumn{7}{c}{ Sólidos em Suspensão - (mg/L) } \\
\hline & \multicolumn{7}{|c|}{2012} & \multicolumn{3}{c}{2013} \\
\hline Variável & Total & Fixo & Volátil & Total & Fixo & Volátil \\
\hline Média & 4490 & 1303 & 3188 & 4404 & 1434 & 2970 \\
\hline Máximo & 7485 & 2692 & 6015 & 7930 & 3850 & 6025 \\
\hline Mínimo & 2358 & 517 & 1842 & 2590 & 670 & 1020 \\
\hline DP & 783 & 305 & 555 & 914 & 394 & 611 \\
\hline CV (\%) & 17 & 23 & 17 & 21 & 27 & 21 \\
\hline N & 359 & & 309 & \\
\hline
\end{tabular}


Tabela 18: Sólidos em suspensão nos tanques de aeração (2014 e 2015)

\begin{tabular}{c|c|c|c|c|c|c}
\hline \multicolumn{7}{|c}{ Sólidos em Suspensão - (mg/L) } \\
\hline & \multicolumn{2}{|c|}{2014} & \multicolumn{3}{c}{2015} \\
\hline Variável & Total & Fixo & Volátil & Total & Fixo & Volátil \\
\hline Média & 4447 & 1302 & 3146 & 4444 & 1385 & 3069 \\
\hline Máximo & 6995 & 4100 & 4845 & 7200 & 2630 & 6250 \\
\hline Mínimo & 3210 & 490 & 2245 & 1605 & 195 & 1140 \\
\hline DP & 662 & 316 & 432 & 780 & 323 & 579 \\
\hline CV (\%) & 15 & 24 & 14 & 18 & 23 & 19 \\
\hline N & 284 & & \multicolumn{5}{c}{359} \\
\hline
\end{tabular}

Figura 53: Diagramas Box-Whiskers da Série de Sólidos nos tanques de aeração



Os resultados mostram que nos quatro períodos os tanques de aeração operaram com concentrações de SST e SSV nos lodos muito próximas entre si e relativamente elevadas, típicas dos processos com idade do lodo mais avançada (aeração prolongada). A relação SSV/SST resultou em $0,71,0,67,0,71$ e 0,69 nos lodos dos tanques nos anos de 2012, 2013, 2014 e 2015, respectivamente. Estes números estão associados a um bom nível de digestão do lodo, sendo possível a secagem sem digestão complementar.

Considerando-se as cargas de DBO apresentadas na Tabela 16, as concentrações de SSV das Tabelas 17 e 18 e o volume útil total dos tanques de aeração de 27.570 $\mathrm{m}^{3}$, a relação alimento/microrganismos resultantes são de $0,15,0,18,0,16$ e 0,17 kgDBO/kgSSV.dia para os anos de 2012, 2013, 2014 e 2015, respectivamente. Com exceção do ano de 2012, os valores resultaram acima da referência de 0,15 
kgDBO/kgSSV.dia apresentada na literatura como valor limite para lodo ativado com aeração prolongada.

\subsubsection{Sólidos em suspensão totais no esgoto à saída do processo de lodos ativados}

$\mathrm{Na}$ Tabela 19, apresenta-se as concentrações de sólidos em suspensão totais no esgoto à saída do processo de lodos ativados obtidas durante o período de 2012 a 2015 da pesquisa. Com os dados das determinações da série de sólidos, construímos a Figura 54, onde observa-se a mediana, os quartis (inferior e superior) e a dispersão dos dados obtidos durante o período de estudo.

Tabela 19: Sólidos em suspensão total no efluente final da ETE

\begin{tabular}{c|c|c|c|c}
\hline \multicolumn{5}{c}{ SST (mg/L) } \\
\hline Variável & $\mathbf{2 0 1 2}$ & $\mathbf{2 0 1 3}$ & $\mathbf{2 0 1 4}$ & $\mathbf{2 0 1 5}$ \\
\hline média & 206 & 208 & 66 & 117 \\
\hline máximo & 530 & 745 & 310 & 375 \\
\hline mínimo & 0 & 0 & 0 & 10 \\
\hline DP & 206 & 208 & 66 & 117 \\
\hline CV (\%) & 64 & 68 & 93 & 65 \\
\hline $\mathbf{n}$ & 305 & 296 & 195 & 204 \\
\hline
\end{tabular}

Figura 54: Diagramas Box-Whiskers da concentração de SST no Afluente e Efluente da ETE

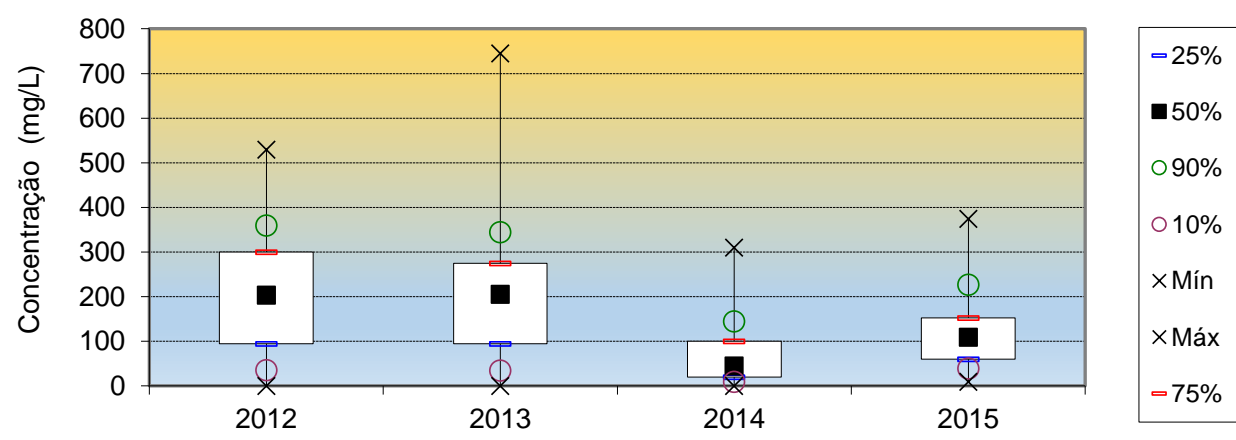


Os resultados mostram uma forte ocorrência de perdas de sólidos em suspensão no efluente nos anos de 2012 e 2013 com médias de 206 e 208 mg/L, respectivamente. Esses valores podem ser atribuídos ao fato da falta de um controle mais efetivo na operação do processo e pela dificuldade no período na retirada de sólidos no sistema. Em uma parte do ano de 2013 e mais efetivamente nos anos de 2014 e 2015, foram instalados os controladores e sensores de monitoramento online dos parâmetros de interesse da pesquisa e a instalação de uma centrifuga de maior capacidade para retirada dos sólidos em excesso do sistema. Essas modificações diminuíram a perca de sólidos no processo resultando em concentrações médias de SSV de 66 e 117 mg/L nos anos de 2014 e 2015, respectivamente. No entanto, apesar da melhora na qualidade do efluente final nesse período, em momentos de vazão máxima o arraste de sólidos chegou a concentrações na faixa de 310 a 375 mg/L dificultando a manutenção da idade do lodo no processo.

\subsubsection{Idade do lodo ativado}

Os resultados do controle da idade do lodo ativado exercido durante o estudo são apresentados na Tabela 20 e, em forma de Diagramas Box-Whiskers na Figura 55.

Tabela 20: Valores médios da idade do lodo no sistema de tratamento

\begin{tabular}{c|c|c|c|c}
\hline \multicolumn{5}{c}{ Idade do Lodo (dias) } \\
\hline Variável & 2012 & 2013 & 2014 & 2015 \\
\hline Média & 8 & 10 & 12 & 12 \\
\hline Máximo & 27 & 32 & 30 & 26 \\
\hline Mínimo & 3 & 3 & 3 & 2 \\
\hline DP & 4 & 6 & 4,1 & 5 \\
\hline CV (\%) & 44,2 & 58,1 & 36,0 & 42,0 \\
\hline N & 305 & 305 & 312 & 195 \\
\hline
\end{tabular}


Figura 55: Diagramas Box-Whiskers da idade do lodo ativado na ETE Limoeiro

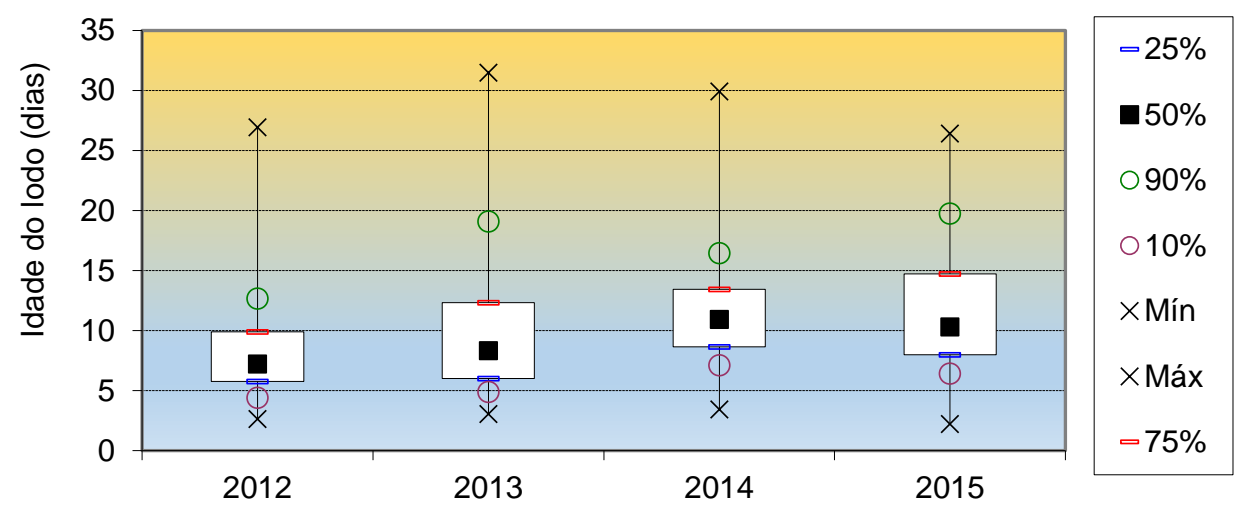

Os resultados da Tabela 20 e da Figura 55, mostram a ocorrência de variação de idade do lodo em faixa ampla em ambos os períodos. Isto deveu-se principalmente à variação na perda de sólidos com o efluente final, que ocorreu de forma excessiva no ano de 2012 e em boa parte do ano de 2013. Levando-se em conta a perda de sólidos, a idade do lodo média foi de 8, 10, 12 e 12 dias nos anos de 2012, 2013, 2014 e 2015, respectivamente. Conforme já mencionado, em parte do ano de 2013 e no período de 2014 a 2015 foi feito um melhor controle operacional no processo de tratamento, foi realizada a instalação dos controladores e medidores online das variáveis de interesse do estudo e, a instalação de uma centrifuga de maior capacidade para retirada de sólidos. Essas alterações resultaram em uma melhor estabilidade operacional do sistema que foi mais efetiva nos anos de 2014 e 2015 o que resultou em uma idade média do lodo 12 dias. Embora a ocorrência de idade do lodo baixa em determinados períodos, foi possível obter a nitrificação e desnitrificação no processo, isto demonstra que não há grande diferença entre a idade do lodo mínima para a nitrificação entre os processos com baixa concentração de OD nos tanques, em torno de $0,5 \mathrm{mgO}_{2} / \mathrm{L}$ e os com condições normais de aeração, em que se mantém o OD na faixa de 1,5 mg/L. Esta constatação é bastante motivadora, por indicar que é possível obter a nitrificação/desnitrificação simultânea em faixa de idade do lodo mais ampla do que era suposto na literatura. 


\subsection{5 Índice volumétrico do lodo}

$\mathrm{Na}$ Tabela 21, apresenta-se os resultados do índice volumétrico do lodo (IVL) obtido durante o período de estudo, com esses resultados construímos a Figura 56, onde observa-se a mediana, os quartis (inferior e superior) e a dispersão dos dados obtidos durante o período de estudo.

Tabela 21: Índice volumétrico do lodo no tanque de aeração

\begin{tabular}{c|c|c|c|c}
\hline \multicolumn{6}{c}{ IVL (mL/g) } \\
\hline Variável & $\mathbf{2 0 1 2}$ & $\mathbf{2 0 1 3}$ & $\mathbf{2 0 1 4}$ & $\mathbf{2 0 1 5}$ \\
\hline Média & 203 & 179 & 191 & 194 \\
\hline Máximo & 291 & 447 & 269 & 368 \\
\hline Mínimo & 121 & 22 & 69 & 72 \\
\hline DP & 34 & 45 & 31 & 44 \\
\hline CV (\%) & 17 & 25 & 16 & 23 \\
\hline N & 282 & 311 & 308 & 309 \\
\hline
\end{tabular}

Figura 56: Diagramas Box-Whiskers do IVL no tanque de aeração da ETE Limoeiro

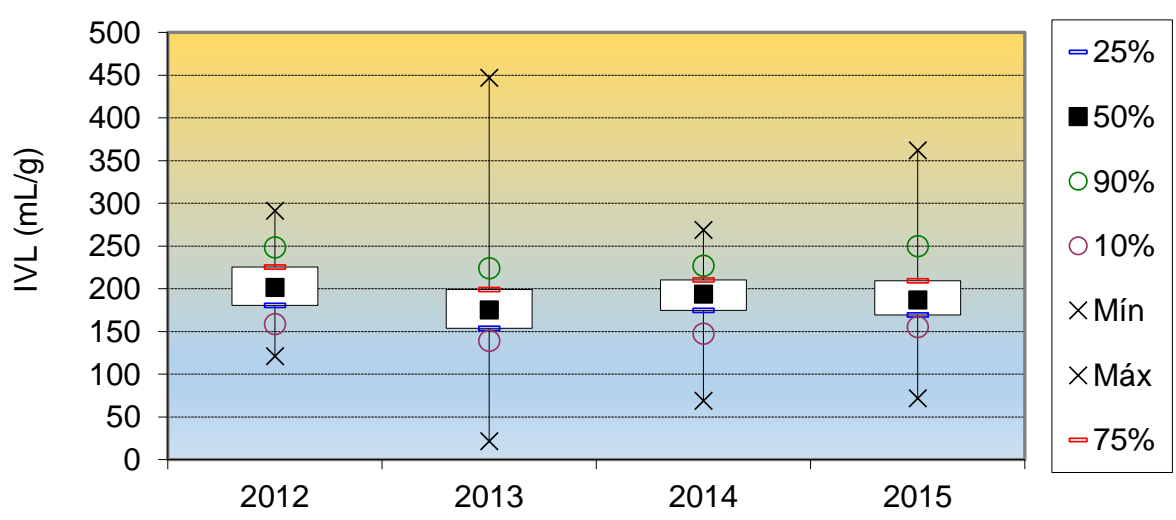

Os resultados da Tabela 21 mostram valores médios de IVL de 203, 179, 191 e 194 $\mathrm{mL} / \mathrm{g}$ para os anos de 2012, 2013, 2014 e 2015, respectivamente. Tendo-se o valor de $100 \mathrm{~mL} / \mathrm{g}$ como referência para a indicação de boa condição de sedimentabilidade, observa-se na Figura 56 valores bem acima, com pico de $447 \mathrm{~mL} / \mathrm{g}$. Valores elevados de IVL em sistemas de lodos ativados operados com baixa aeração são descritos na literatura. No estudo de Schuyler, et al. (2009), os resultados de IVL foram de 300 a 
$600 \mathrm{~mL} / \mathrm{g}$ com OD na faixa de 0,65 a $0,90 \mathrm{mgO} / \mathrm{L}$ e idade do lodo de 5 dias e, na faixa de 200 a $380 \mathrm{~mL} / \mathrm{g}$ com o OD na faixa de $0,50 \mathrm{mgO} / \mathrm{L}$ e idade do lodo de 12 dias. No estudo de Bueno, 2011 com OD na faixa de 0,3 a 0,8 $\mathrm{mg} \mathrm{O}_{2} / \mathrm{L}$ o IVL ficou na faixa de $189 \pm 40$ para idade do lodo em torno de 40 dias e $210 \pm 9$ para idade do lodo de 30 dias e 170 \pm 20 para idade do lodo de 20 dias. Os resultados mostram que independentemente da idade do lodo e relação A/M sistemas operados com baixa concentração de OD no tanque de aeração tendem a apresentar valores de IVL maiores que os processos tradicionais. De fato, essas condições evidenciam os riscos da ocorrência de perda excessiva de sólidos com o efluente final.

\subsubsection{Determinação da velocidade de sedimentação do lodo}

As Tabelas 22 e 23 mostram a variação da alturara da interface do lodo em diferentes concentrações de sólidos em função do tempo durante o teste de sedimentabilidade. Os testes foram feitos em triplicatas, a diluição do lodo ativado foi feita com esgoto tratado da própria estação. Os testes foram realizados em duas condições, uma com o lodo coletado diretamente do tanque de aeração com o OD na faixa de 0,3 a 0,8 $\mathrm{mgO}_{2} / \mathrm{L}$ e outra com OD na faixa de 1,0 a $1,5 \mathrm{mgO}_{2} / \mathrm{L}$ (o lodo era submetido previamente por aeração de 2 horas antes do teste, a aeração foi controlada pelo respirômetro).

Tabela 22: Altura da interface do lodo em diferentes tempos do teste $(O D=0,3$ a 0,8 $\left.\mathrm{mgO}_{2} / \mathrm{L}\right)$

\begin{tabular}{c|c|c|c|c|c|c|c|c|c|c|c|c|c}
\hline Condições & \multicolumn{10}{c}{ Altura da interface (metros) } \\
\hline $3,5\left(\mathrm{kgSSV} / \mathrm{m}^{3}\right)$ & 0,50 & 0,50 & 0,48 & 0,46 & 0,42 & 0,38 & 0,34 & 0,30 & 0,28 & 0,26 & 0,24 & 0,22 & 0,20 \\
\hline $2,8\left(\mathrm{kgSSV} / \mathrm{m}^{3}\right)$ & 0,50 & 0,49 & 0,45 & 0,38 & 0,34 & 0,30 & 0,26 & 0,24 & 0,22 & 0,16 & 0,14 & 0,12 & 0,10 \\
\hline $2,1\left(\mathrm{kgSSV} / \mathrm{m}^{3}\right)$ & 0,50 & 0,46 & 0,34 & 0,28 & 0,24 & 0,18 & 0,15 & 0,12 & 0,10 & 0,08 & 0,07 & 0,07 & 0,07 \\
\hline $1,4\left(\mathrm{kgSSV} / \mathrm{m}^{3}\right)$ & 0,50 & 0,44 & 0,32 & 0,22 & 0,18 & 0,14 & 0,12 & 0,11 & 0,10 & 0,09 & 0,08 & 0,07 & 0,06 \\
\hline $0,7\left(\mathrm{kgSSV} / \mathrm{m}^{3}\right)$ & 0,50 & 0,42 & 0,28 & 0,20 & 0,16 & 0,12 & 0,11 & 0,10 & 0,09 & 0,08 & 0,08 & 0,07 & 0,07 \\
\hline Tempo $(\mathrm{min})$ & 0 & 1 & 2 & 5 & 10 & 15 & 20 & 25 & 30 & 45 & 60 & 75 & 90 \\
\hline
\end{tabular}


Tabela 23: Altura da interface do lodo em diferentes tempos do teste $(O D=1,0$ a 1,5 $\left.\mathrm{mgO}_{2} / \mathrm{L}\right)$

\begin{tabular}{c|c|c|c|c|c|c|c|c|c|c|c|c|c}
\hline Condições & \multicolumn{10}{c}{ Altura da interface (metros) } \\
\hline $3,5\left(\mathrm{kgSSV} / \mathrm{m}^{3}\right)$ & 0,50 & 0,50 & 0,45 & 0,38 & 0,32 & 0,28 & 0,24 & 0,20 & 0,18 & 0,18 & 0,16 & 0,15 & 0,15 \\
\hline $2,8\left(\mathrm{kgSSV} / \mathrm{m}^{3}\right)$ & 0,50 & 0,49 & 0,40 & 0,35 & 0,30 & 0,26 & 0,22 & 0,18 & 0,13 & 0,13 & 0,12 & 0,11 & 0,10 \\
\hline $2,1\left(\mathrm{kgSSV} / \mathrm{m}^{3}\right)$ & 0,50 & 0,40 & 0,35 & 0,30 & 0,22 & 0,16 & 0,10 & 0,08 & 0,06 & 0,06 & 0,05 & 0,05 & 0,05 \\
\hline $1,4\left(\mathrm{kgSSV} / \mathrm{m}^{3}\right)$ & 0,50 & 0,35 & 0,30 & 0,22 & 0,14 & 0,06 & 0,06 & 0,06 & 0,05 & 0,05 & 0,05 & 0,05 & 0,05 \\
\hline $0,7\left(\mathrm{kgSSV} / \mathrm{m}^{3}\right)$ & 0,50 & 0,35 & 0,28 & 0,15 & 0,08 & 0,04 & 0,04 & 0,04 & 0,04 & 0,04 & 0,04 & 0,04 & 0,04 \\
\hline Tempo $(\mathrm{min})$ & 0 & 1 & 2 & 5 & 10 & 15 & 20 & 25 & 30 & 45 & 60 & 75 & 90 \\
\hline
\end{tabular}

Desprezando-se o ponto inicial $\mathrm{t}=0$ minutos e os pontos a partir de $\mathrm{t}=45$ minutos, que não configuram um trecho retilíneo, tem-se a reta de melhor ajuste aos pontos $t$ $=1$ minutos a $\mathrm{t}=30$ minutos. A reta de melhor ajuste e a sua inclinação podem ser observadas nas Figuras 57 e 58.

Figura 57: Altura da interface do lodo em função do tempo (OD = 0,3 a 0,8 mg/L)

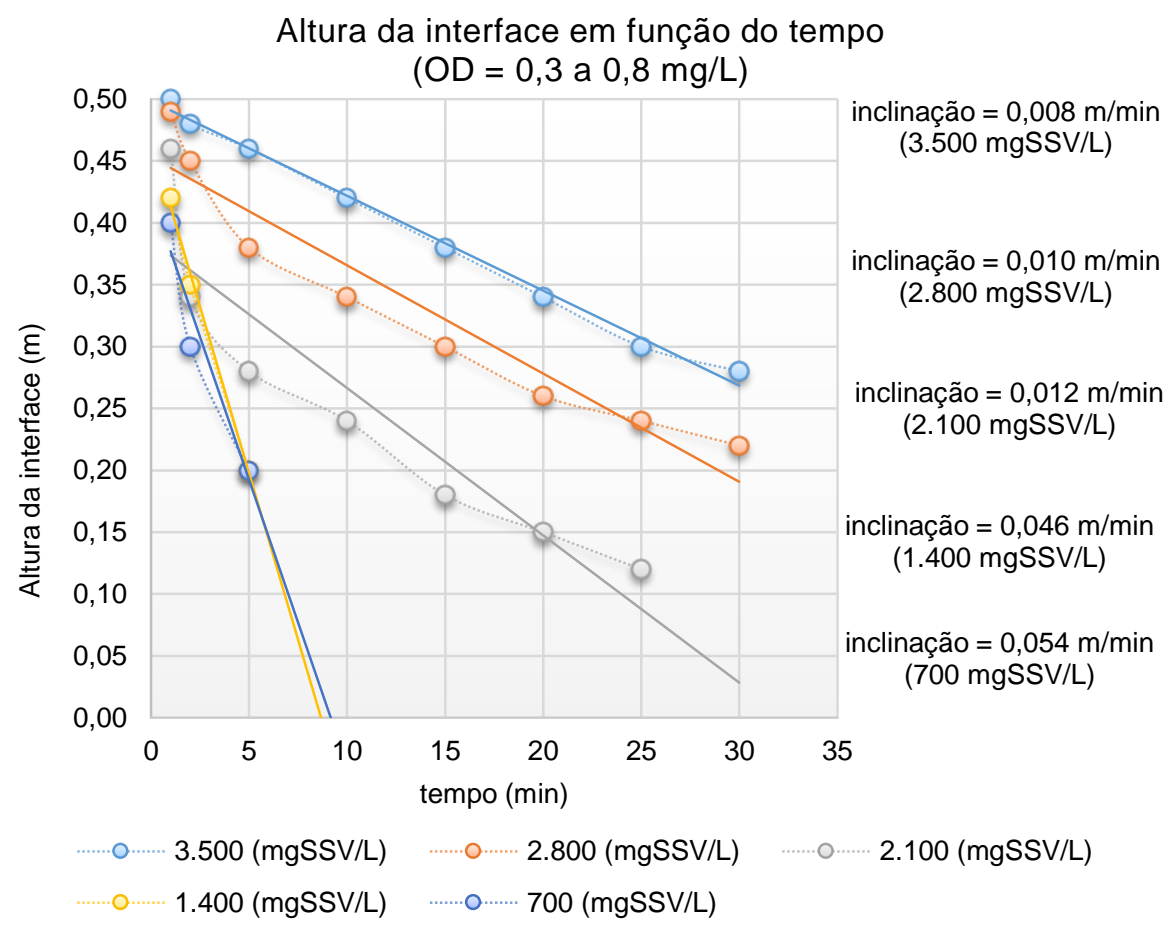


Figura 58: Altura da interface do lodo em função do tempo (OD = 1,0 a 1,5 mg/L)

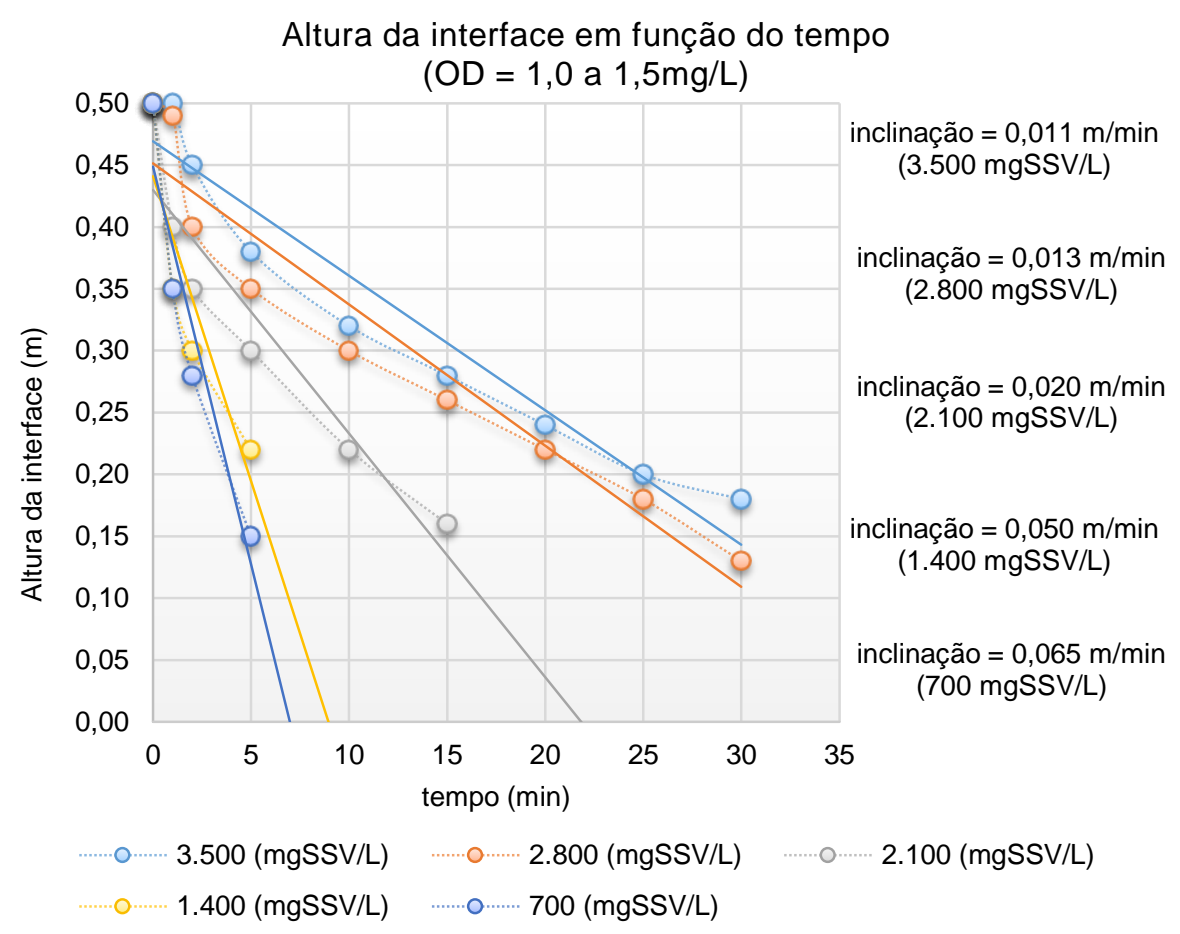

A análise de regressão linear com os dados de altura da interface do lodo $x$ tempo de sedimentação, resultou em condições normais de operação velocidades de $0,48,0,60$, $0,72,2,76$ e $3,24 \mathrm{~m} / \mathrm{h}$ e nos testes em bancada com OD na faixa de 1,0 a $1,5 \mathrm{mgO} / \mathrm{L}$ as velocidades foram de $0,66,0,78,1,20,3,00$ e 3,90 m/h para as concentrações de $0,7,1,4,2,1,2,8$ e $3,5 \mathrm{kgSSV} / \mathrm{m}^{3}$, respectivamente.

Para o cálculo de sedimentação v pode ser calculado pela equação:

$\mathrm{V}=\mathrm{V}_{0}{ }^{*} \mathrm{e}^{-\mathrm{k} . \mathrm{C}}$ ou $\quad \ln \mathrm{V}=\ln \mathrm{V}_{\mathrm{o}}-\mathrm{K}^{*} \mathrm{C}$

Onde:

$\mathrm{V}_{\mathrm{o}}=$ coeficiente, expressando a velocidade de sedimentação da interface numa concentração hipotética $\mathrm{C}=0(\mathrm{~m} / \mathrm{h})$;

$\mathrm{K}=$ coeficiente de sedimentação $\left(\mathrm{m}^{3} / \mathrm{kg}\right)$.

Combinando os resultados da regressão linear com as concentrações de sólidos construímos a Figura 59, onde se observa a velocidade de sedimentação da interface do lodo em função da concentração de sólidos. 
Figura 59: Velocidade de sedimentação da interface do lodo em função da concentração de sólidos
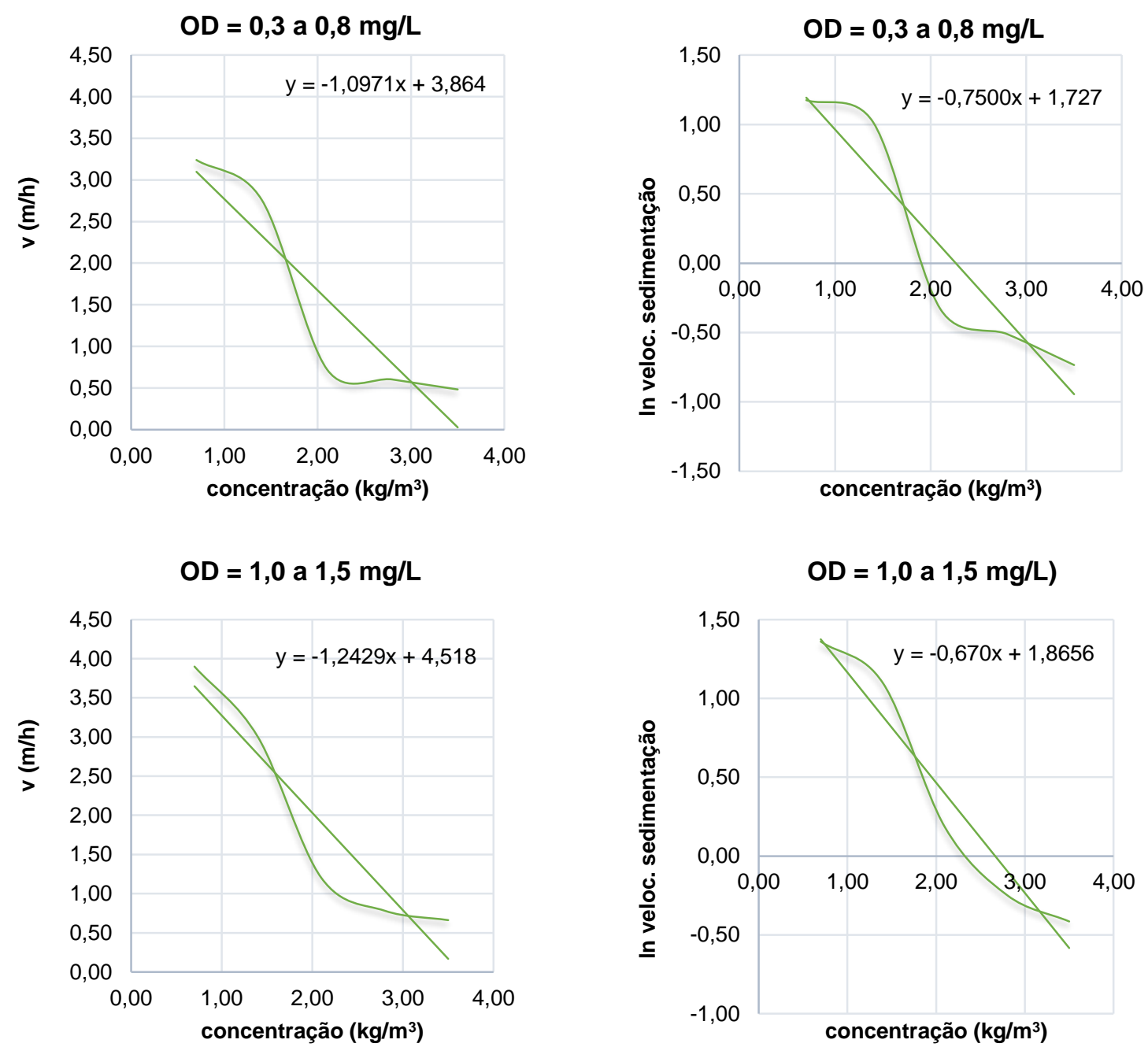

Com os dados do gráfico da Figura 59 calculamos os coeficientes da equação X que são apresentados na Tabela 24.

Tabela 24: Coeficientes do teste de sedimentabilidade do lodo ativado

\begin{tabular}{c|c|c}
\hline Variáveis & OD (0,3 a $\mathbf{0 , 8} \mathbf{~ m g} / \mathbf{L})$ & OD (1,0 a 1,5 $\mathbf{~ g} / \mathbf{L})$ \\
\hline $\ln \mathrm{V}_{\circ}$ & 1,73 & 1,93 \\
\hline $\mathrm{V}_{\circ}(\mathrm{m} / \mathrm{h})$ & 5,62 & 6,90 \\
\hline $\mathrm{K}\left(\mathrm{kg} / \mathrm{m}^{3}\right)$ & 0,75 & 0,67 \\
\hline
\end{tabular}


Com os coeficientes dos testes de sedimentabilidade do lodo contruímos a Tabela 25, onde se apresenta as velocidades de sedimentação do lodo variando de 0 a 5,0 $\mathrm{kgSSV} / \mathrm{m}^{3}$.

Tabela 25: Velocidades de sedimentação para diferentes concentrações de sólidos

\begin{tabular}{|c|c|c|c|}
\hline$C\left(\mathrm{~kg} / \mathrm{m}^{3}\right)$ & $\begin{array}{l}\text { Condições normais } \\
O D=0,3 \text { a } 0,8 \mathrm{mg} / \mathrm{L}\end{array}$ & $\begin{array}{l}\text { Teste após aeração } \\
O D=1,0 \text { a } 1,5 \mathrm{mg} / \mathrm{L}\end{array}$ & $\begin{array}{c}\text { Valores de Referência } \\
\text { para lodos ativados } \\
\text { (VON SPERLING, 1997) }\end{array}$ \\
\hline & $v(m / h)$ & $\mathbf{v}(\mathrm{m} / \mathrm{h})$ & $v(\mathrm{~m} / \mathrm{h})$ \\
\hline 0,0 & 5,62 & 6,89 & 7,40 \\
\hline 0,5 & 3,84 & 4,93 & 5,29 \\
\hline 1,0 & 2,62 & 3,53 & 3,79 \\
\hline 1,5 & 1,79 & 2,52 & 2,71 \\
\hline 2,0 & 1,22 & 1,80 & 1,94 \\
\hline 2,5 & 0,83 & 1,29 & 1,39 \\
\hline 3,0 & 0,57 & 0,92 & 0,99 \\
\hline 3,5 & 0,39 & 0,66 & 0,71 \\
\hline 4,0 & 0,27 & 0,47 & 0,51 \\
\hline 4,5 & 0,18 & 0,34 & 0,36 \\
\hline 5,0 & 0,12 & 0,24 & 0,26 \\
\hline
\end{tabular}

Os resultados com o lodo sob as condições de baixa aeração foram inferiores aos obtidos em processos de lodo ativado com aeração prolongada, onde temos valores típicos de $\mathrm{V}_{0}$ de 8,6 a $10,0 \mathrm{~m} / \mathrm{h}$ indicando de média a ótima sedimentabilidade e valores entre 5,6 a 6,2 m/h indicando péssima à ruim sedimentabilidade do lodo (VON SPERLING, 2002). No entanto, no teste onde o lodo foi submetido a uma prévia aeração (2 horas) na faixa de 1,0 a 1,5 mgO2/L, nota-se uma melhora significativa na velocidade de sedimentação do lodo, com valor médio de $\mathrm{V}_{\mathrm{o}}=6,9 \mathrm{~m} / \mathrm{h}$. Nesse caso, quando se compara os dados da Tabela 25 com os valores da referencia temos uma boa aproximação dos valores, indicando uma melhora na floculação do lodo biológico. Na ETE Limoeiro, devido a limitações no sistema de aeração não foi possível testar valores maiores de OD no tanque de aeração. No entanto, os resultados mostram que é possível uma melhora significativa na sedimentabilidade do lodo ao se operar os 
tanques de aeração com uma concentração mais elevada nas porções finais de cada tanque. As Figuras 60 e 61 mostram o teste realizado em condições normais e o teste após a aeração.

Figura 60: Teste de sedimentabilidade em condições normais de operação

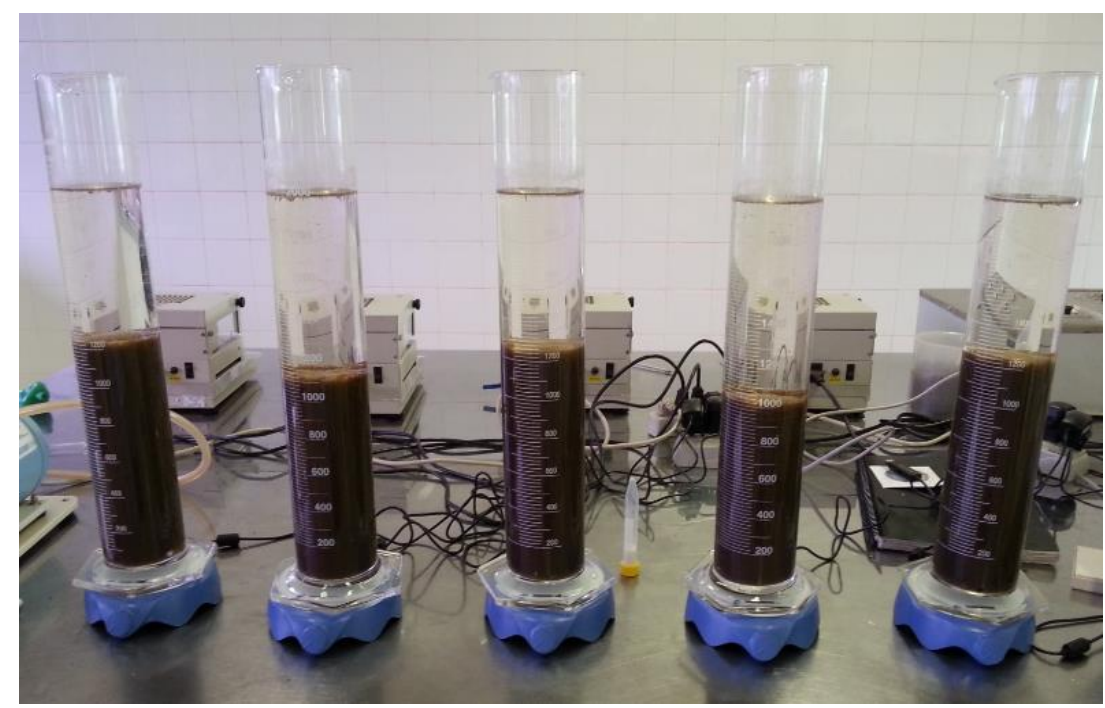

Figura 61: Teste de sedimentabilidade após 2 horas de aeração do lodo

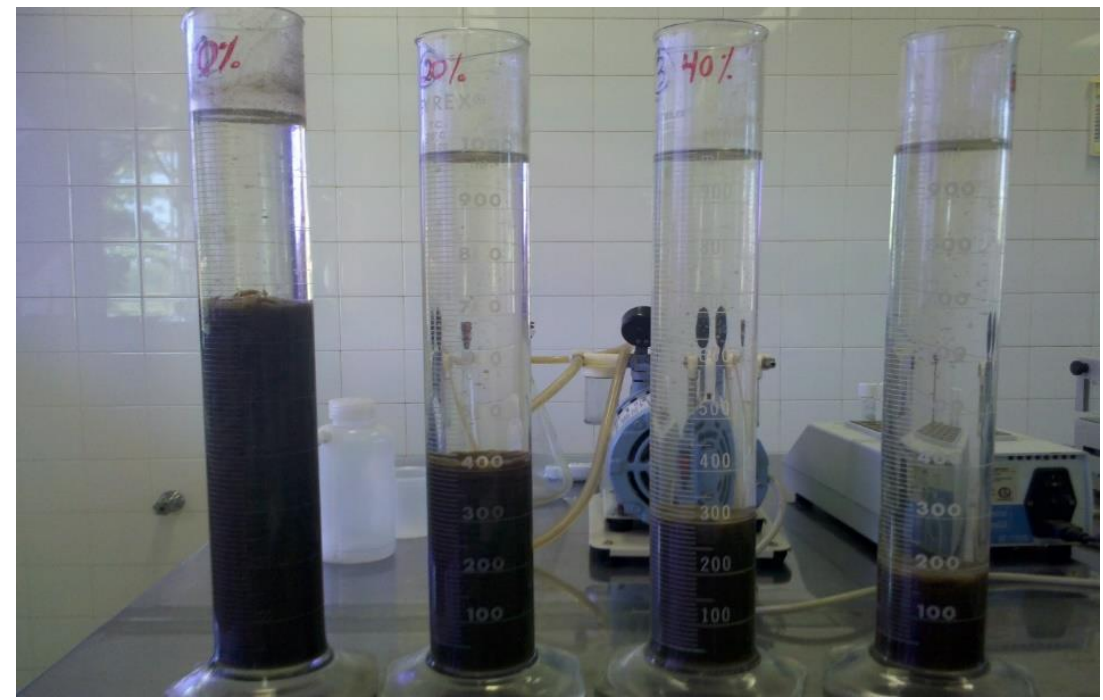

\subsubsection{Caracterização morfológica dos flocos do lodo ativado}

A Figura 62 apresenta um dos testes com as imagens dos flocos do lodo ativado analisados durante o período de estudo. Com os dados obtidos na caracterização dos 
flocos construímos a Tabela 26 onde são apresentados os resultados estatísticos do diâmetro dos flocos.

Figura 62: Imagens digitais adquiridas por microscopia (aumento 40X) e tratadas no programa Image (a) imagem dos flocos identificadas pelo progrma (b) imagem tratada para análise estatística.
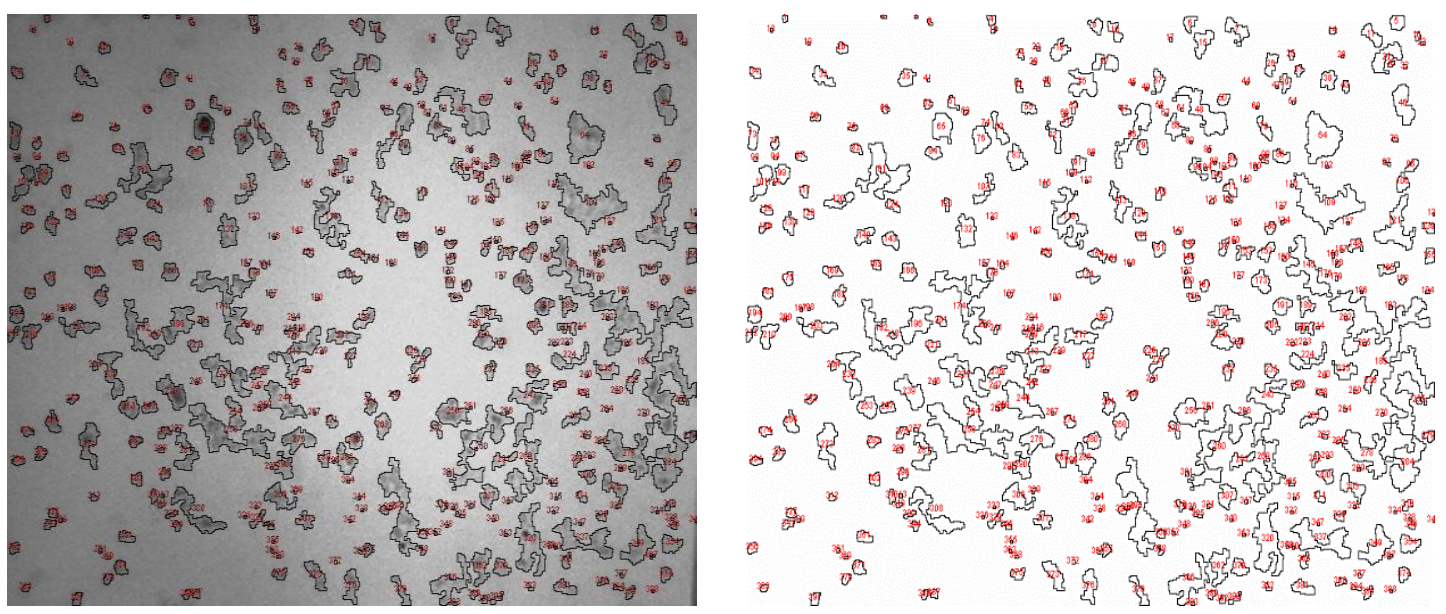

Tabela 26: Estatística descritiva do diâmetro dos flocos do lodo

\begin{tabular}{c|c}
\hline \multicolumn{2}{|c|}{ Diâmetro $\left(\mu_{\mathrm{m}}\right)$} \\
\hline Média & 90 \\
\hline Máximo & 400 \\
\hline Mínimo & 11 \\
\hline DP & 41 \\
\hline CV $(\%)$ & 5 \\
\hline N & 4.913 \\
\hline
\end{tabular}

Os resultados mostram uma grande variação no diâmetro dos flocos que foi de 11 a $400 \mu \mathrm{m}$, com valor médio de $90 \mu \mathrm{m}$. Segundo Jordão \& Pessoa, valores entre $100 \mathrm{a}$ $300 \mu \mathrm{m}$ representam uma boa sedimentabilidade do lodo. Nota-se que os valores encontrados nesse estudo ficaram abaixo do recomendado. Esses resultados junto com os testes de sedimentabilidade reforçam a necessidade de se manter uma zona a jusante dos tanques de aeração com concentrações de OD mais elevadas para uma melhor floculação do lodo biológico.

\subsubsection{Concentrações de OD nos tanques de aeração}

Na Figura 63, observa-se os valores diários em série temporal com médias móveis de 4 termos das concentrações de OD nos tanques de aeração. Esses valores 
correspondem à média das medições de OD realizada e registrada a cada segundo diariamente durante todo o período do estudo.

Figura 63: Série temporal (média diária): OD nos tanques de aeração
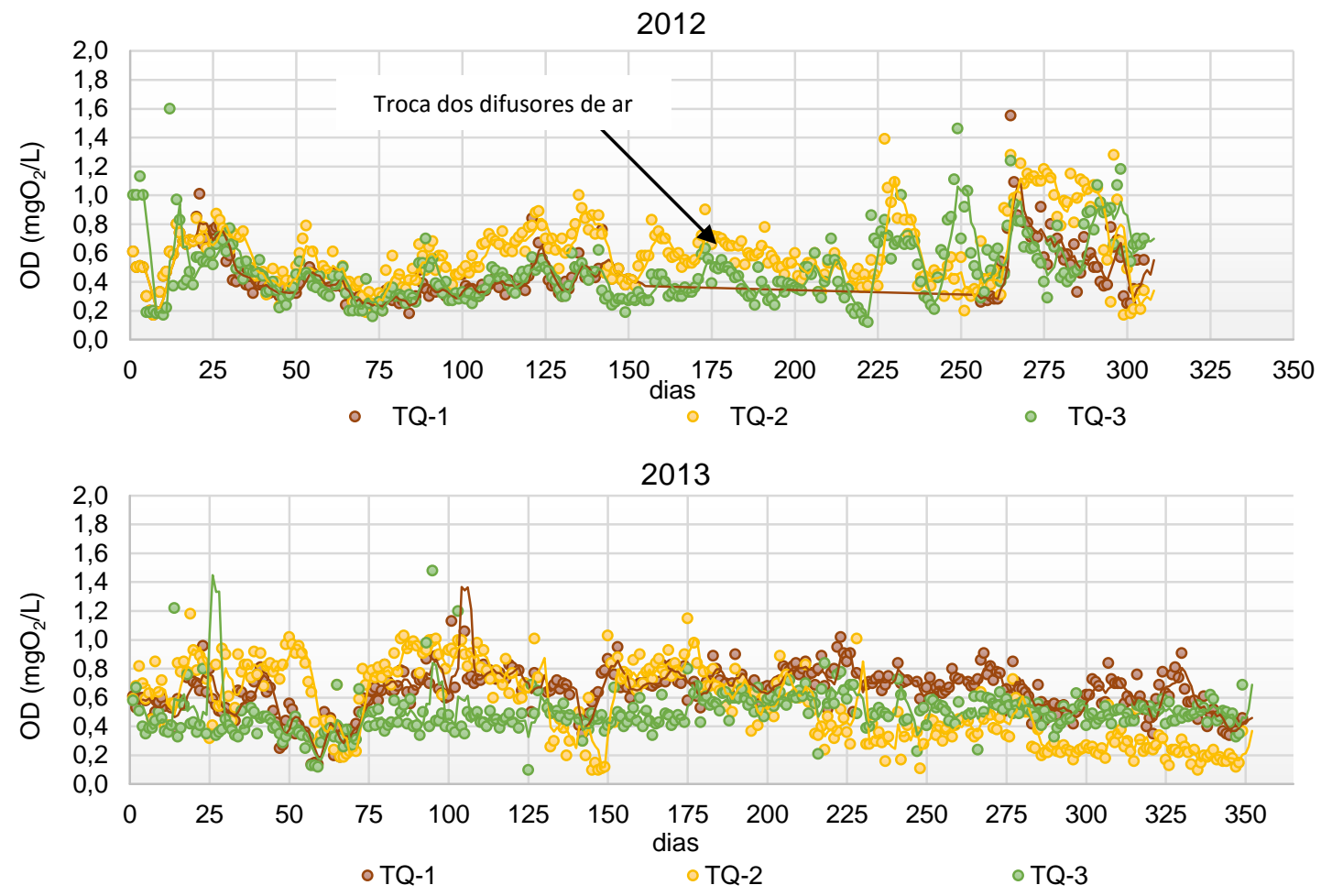

2014

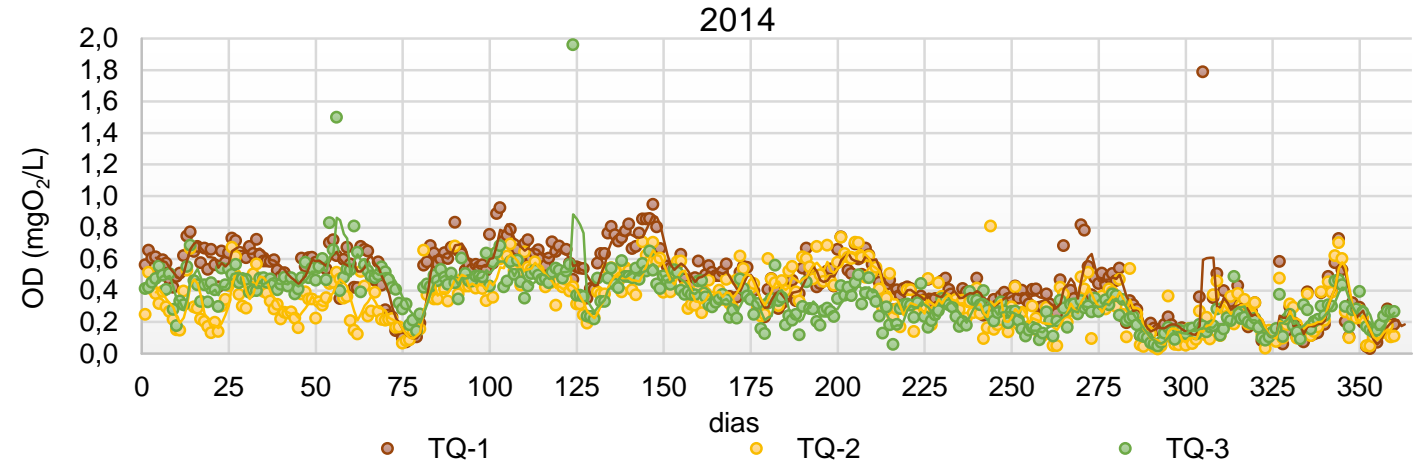

2015

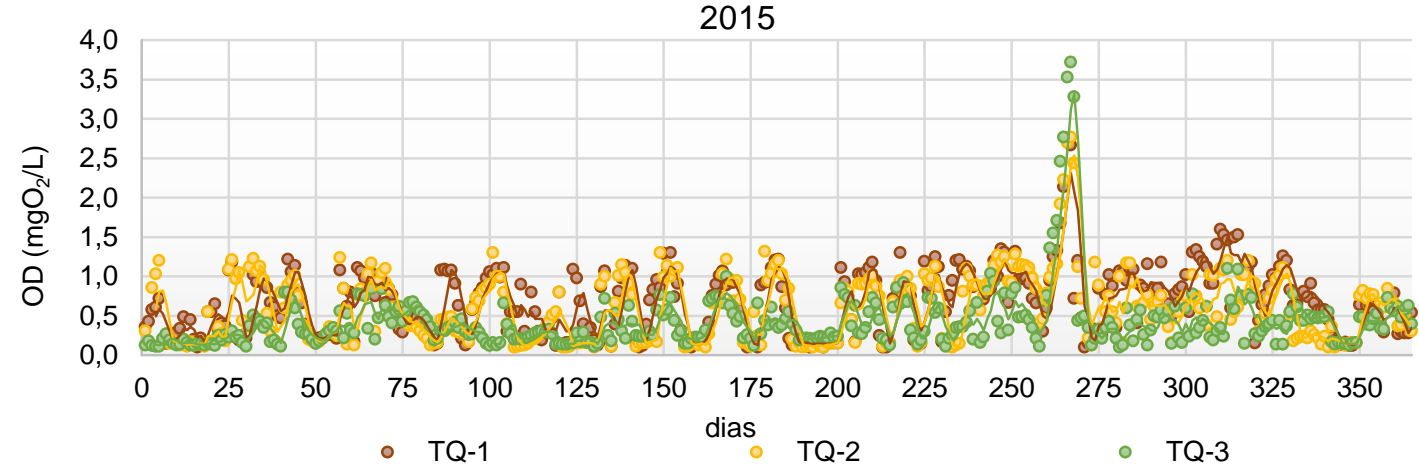


No ano de 2012, início do estudo, o controle e monitoramento do OD nos tanques foram realizados por meio de sondas instaladas na porção final de cada tanque de aeração, não era feito o controle online do OD nas porções iniciais e médias dos tanques, esses ajustes eram pontuais por meio de medidores portáteis de OD. Ainda, no período de $150^{\circ}$ a $260^{\circ}$ dias o tanque 1 foi desativado para a troca do sistema de aeração, o que sobre carregou os outros tanques. No entanto, mesmo com o controle debilitado da aeração observa-se na Figura 63 que no ano de 2012 foi possível controlar razoavelmente a concentração de OD nos tanques de aeração dentro da

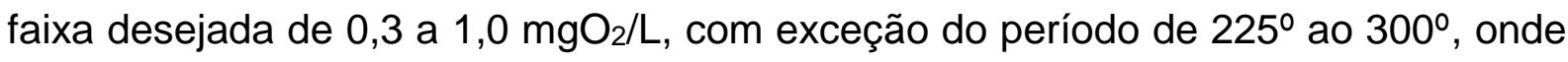
tivemos picos de $\sim 1,5 \mathrm{mgO}_{2} / \mathrm{L}$. No ano de 2013, todos os controladores e sensores online de OD foram instalados e colocados em operação, isso possibilitou o controle mais efetivo da aeração e manter a concentração de OD dentro da faixa proposta no estudo. Na Figura 63, observa-se que praticamente em todo período o OD ficou na faixa entre 0,3 a 1,0 mgO $/ \mathrm{L}$, essas condições se repetem no ano de 2014 e 2015, nesse último, com picos de $\sim 3,5 \mathrm{mgO} / \mathrm{L}$ no período de $260^{\circ}$ ao $270^{\circ}$ devido a manutenções e justes operacionais. Com os dados da série histórica construímos as Tabelas 27 e 28 e a Figura 64, onde apresentam os resultados médios do controle exercido sobre o sistema de aeração no período de estudo.

Tabela 27: Concentrações de OD nos tanques de aeração (2012-2013)

\begin{tabular}{c|c|c|c|c|c|c}
\hline \multicolumn{7}{c}{ Oxigênio Dissolvido (mgO2/L) } \\
\hline \multirow{2}{*}{ Variável } & \multicolumn{7}{c}{$\mathbf{2 0 1 2}$} & \multicolumn{3}{c}{$\mathbf{2 0 1 3}$} \\
\cline { 2 - 7 } & Tanque 01 & Tanque 02 & Tanque 03 & Tanque 01 & Tanque 02 & Tanque 03 \\
\hline Média & 0,46 & 0,60 & 0,48 & 0,65 & 0,55 & 0,50 \\
\hline Máximo & 1,55 & 1,39 & 1,60 & 2,30 & 1,18 & 2,61 \\
\hline Mínimo & 0,17 & 0,17 & 0,12 & 0,14 & 0,10 & 0,10 \\
\hline DP & 0,19 & 0,23 & 0,23 & 0,18 & 0,27 & 0,20 \\
\hline CV (\%) & 41,9 & 38,8 & 47,6 & 28,0 & 48,0 & 40,0 \\
\hline $\mathbf{N}$ & 203 & 305 & 305 & 355 & 355 & 355 \\
\hline
\end{tabular}


Tabela 28: Concentrações de OD nos tanques de aeração (2014-2015)

\begin{tabular}{|c|c|c|c|c|c|c|}
\hline \multicolumn{7}{|c|}{ Oxigênio Dissolvido $\left(\mathrm{mgO}_{2} / \mathrm{L}\right)$} \\
\hline \multirow{2}{*}{ Variável } & \multicolumn{3}{|c|}{2014} & \multicolumn{3}{|c|}{2015} \\
\hline & Tanque 01 & Tanque 02 & Tanque 03 & Tanque 01 & |Tanque 02 & Tanque 03 \\
\hline Média & 0,46 & 0,34 & 0,35 & 0,67 & 0,59 & 0,43 \\
\hline Máximo & 1,79 & 0,81 & 1,96 & 2,76 & 2,77 & 3,72 \\
\hline Mínimo & 0,03 & 0,03 & 0,05 & 0,10 & 0,10 & 0,10 \\
\hline DP & 0,21 & 0,17 & 0,18 & 0,42 & 0,43 & 0,40 \\
\hline CV (\%) & 46,0 & 49,0 & 51,0 & 63,0 & 73,0 & 94,0 \\
\hline $\mathbf{N}$ & 360 & 360 & 360 & 360 & 360 & 360 \\
\hline
\end{tabular}

Figura 64: Diagramas Box-Whiskers OD nos tanques de aeração

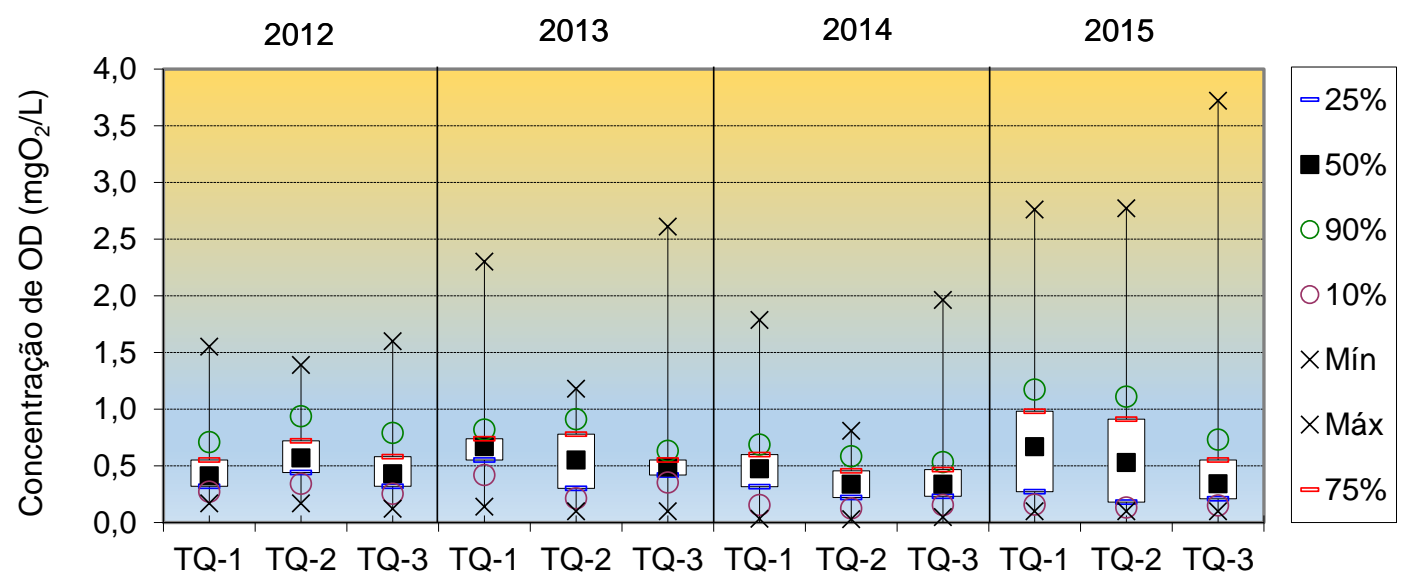

Nas Tabelas 27 e 28 observa-se que as médias das concentrações de OD foram de 0,51, 0,57, 0,38 e 0,56 $\mathrm{mgO}_{2} / \mathrm{L}$ para os anos de 2012, 2013, 2014 e 2015, respectivamente. Independente da dispersão dos dados apresentados na Figura 64, os valores medianos também ficaram entorno de $0,5 \mathrm{mgO}_{2} / \mathrm{L}$ para todo o período de estudo. Isto demostrou que é possível garantir a principal condição para a ocorrência da nitrificação/desnitrificação simultânea, embora o sistema de fornecimento de ar instalado na ETE não tenha sido escolhido para esta finalidade específica.

\subsubsection{Temperatura do lodo ativado nos tanques de aeração}

Na Figura 65, observa-se os valores diários em série temporal com médias móveis de 4 termos da temperatura do lodo ativado nos tanques de aeração. Esses valores 
correspondem à média das medições de temperatura realizada e registrada a cada segundo diariamente durante todo o período do estudo.

Figura 65: Temperatura nos tanques de aeração
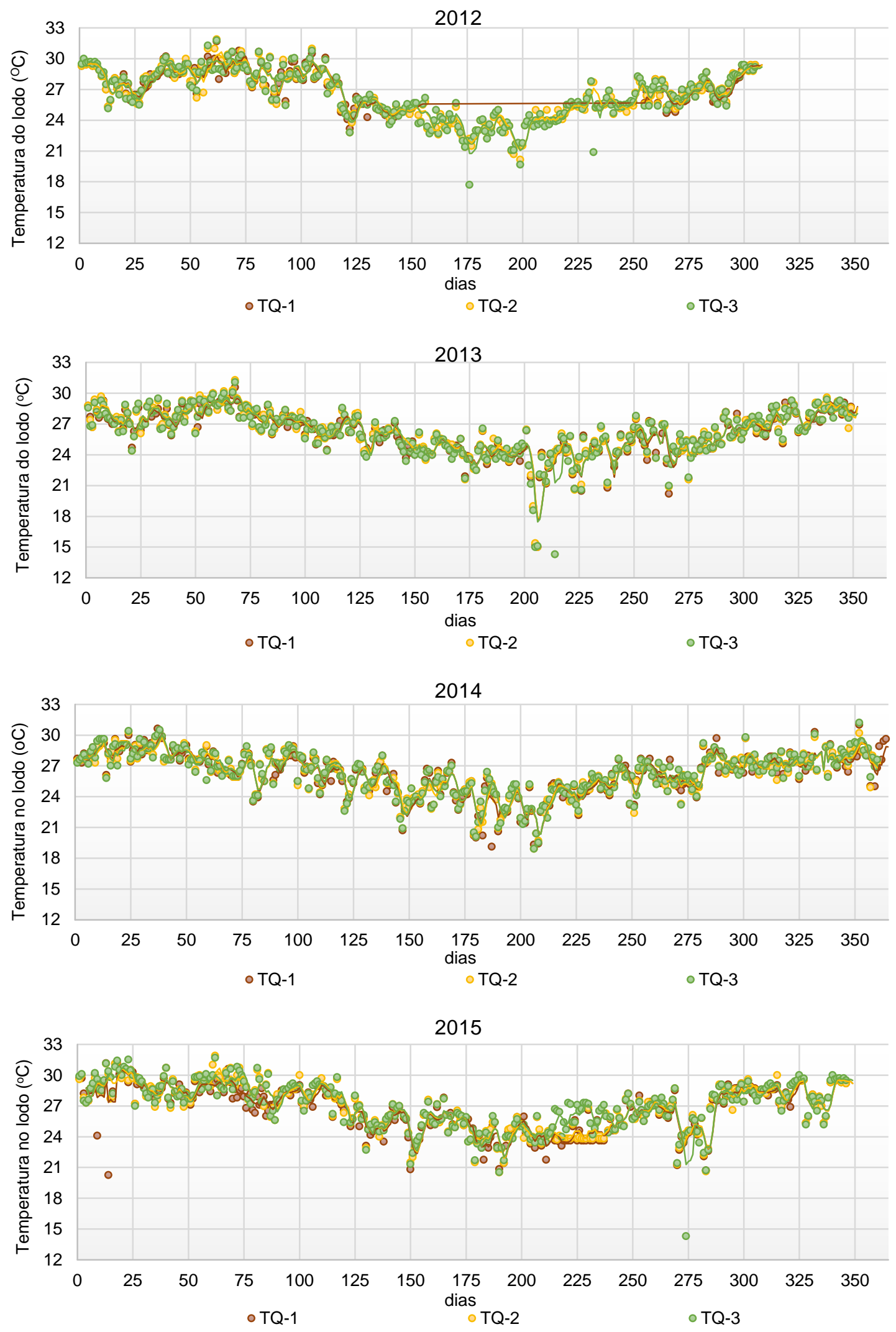
Observa-se que a temperatura do lodo ativado nos tanques de aeração ficou na faixa entre 18 a $32^{\circ} \mathrm{C}$ para o ano de 2012 , entre 14 a $31^{\circ} \mathrm{C}$ no ano de 2013 , entre 19 a $31^{\circ} \mathrm{C}$ no ano de 2014 e de 14 a 32으 para o ano de 2015. Com os dados da série temporal construímos as Tabelas 29 e 30 e a Figura 66.

Tabela 29: Valores médios da temperatura do lodo ativado

\begin{tabular}{c|c|c|c|c|c|c}
\hline \multicolumn{7}{c}{ Temperatura $\left({ }^{\circ} \mathrm{C}\right)$} \\
\hline \multirow{2}{*}{ Variável } & \multicolumn{5}{c}{$\mathbf{2 0 1 2}$} & \multicolumn{3}{c}{$\mathbf{2 0 1 3}$} \\
\cline { 2 - 7 } & Tanque 01 & Tanque 02 & Tanque 03 & Tanque 01 & Tanque 02 & Tanque 03 \\
\hline Média & 27,5 & 26,5 & 26,5 & 26,1 & 26,3 & 26,2 \\
\hline Máximo & 31,7 & 31,9 & 31,8 & 30,6 & 31,3 & 31,1 \\
\hline Mínimo & 23,2 & 20,2 & 17,7 & 15,0 & 15,0 & 14,3 \\
\hline DP & 1,7 & 2,3 & 2,4 & 2,2 & 2,2 & 2,3 \\
\hline CV (\%) & 6,0 & 9,0 & 9,0 & 8,0 & 8,0 & 9,0 \\
\hline $\mathbf{N}$ & 203 & 305 & 305 & 336 & 327 & 336 \\
\hline & & & & & &
\end{tabular}

Tabela 30: Valores médios da temperatura do lodo ativado

\begin{tabular}{c|c|c|c|c|c|c}
\hline \multicolumn{7}{c}{ Temperatura $\left({ }^{\circ} \mathrm{C}\right)$} \\
\hline \multirow{2}{*}{ Variável } & \multicolumn{5}{c|}{2014} & \multicolumn{3}{c}{2015} \\
\cline { 2 - 7 } & Tanque 01 & Tanque 02 & Tanque 03 & Tanque 01 & Tanque 02 & Tanque 03 \\
\hline Média & 26,3 & 26,3 & 26,3 & 26,7 & 26,9 & 27,0 \\
\hline Máximo & 31,0 & 30,3 & 31,2 & 31,2 & 31,9 & 31,7 \\
\hline Mínimo & 19,1 & 18,9 & 18,9 & 20,2 & 20,5 & 14,3 \\
\hline DP & 2,1 & 2,1 & 2,1 & 2,3 & 2,3 & 2,3 \\
\hline CV (\%) & 8,0 & 8,0 & 8,0 & 8,0 & 8,0 & 9,0 \\
\hline $\mathbf{N}$ & 360 & 361 & 361 & 343 & 343 & 343 \\
\hline
\end{tabular}


Figura 66: Diagramas Box-Whiskers da temperatura do lodo ativado

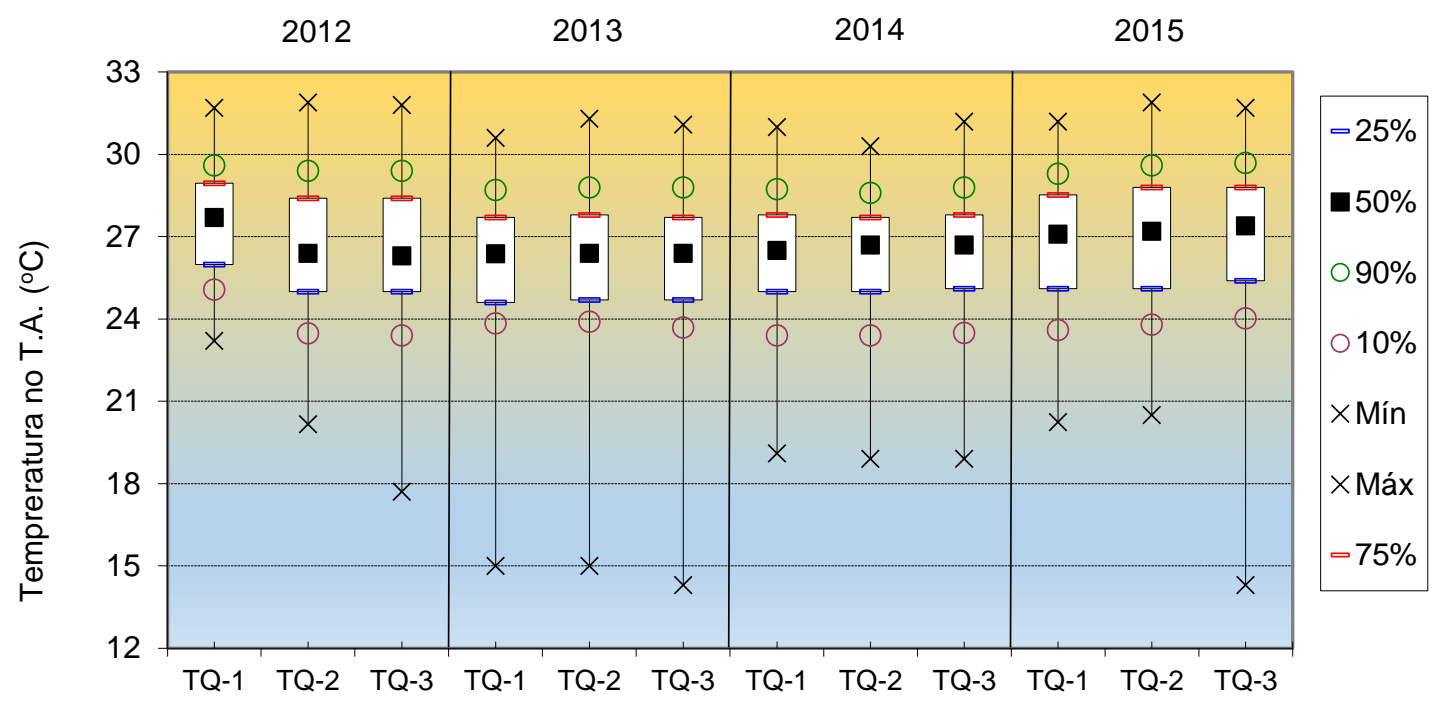

A temperatura média do lodo ativado nos tanques de aeração foram de $26,8,26,2$, 26,3, 26,9으 para os anos de 2012, 2013, 2014 e 2015, respectivamente. A Figura 66 mostra a dispersão dos valores, que atingiu picos acima de $30^{\circ} \mathrm{C}$. Este foi o principal fator para a escolha do local da pesquisa, por corresponder a uma situação bastante favorável para os processos bioquímicos envolvidos, sobretudo a nitrificação.

\subsubsection{0 pH do lodo ativado nos tanques de aeração}

Na Figura 67, observa-se os valores diários em série temporal com médias móveis de 4 termos do controle exercido sobre o pH dos lodos nos tanques de aeração. Esses valores correspondem à média das medições de $\mathrm{pH}$ realizada e registrada a cada segundo diariamente durante todo o período do estudo e são lançados em forma de média nas Tabelas 31 e 32 e sua distribuição pode ser observada na Figura 68. 
Figura 67: pH do lodo ativado nos tanques de aeração da ETE Limoeiro
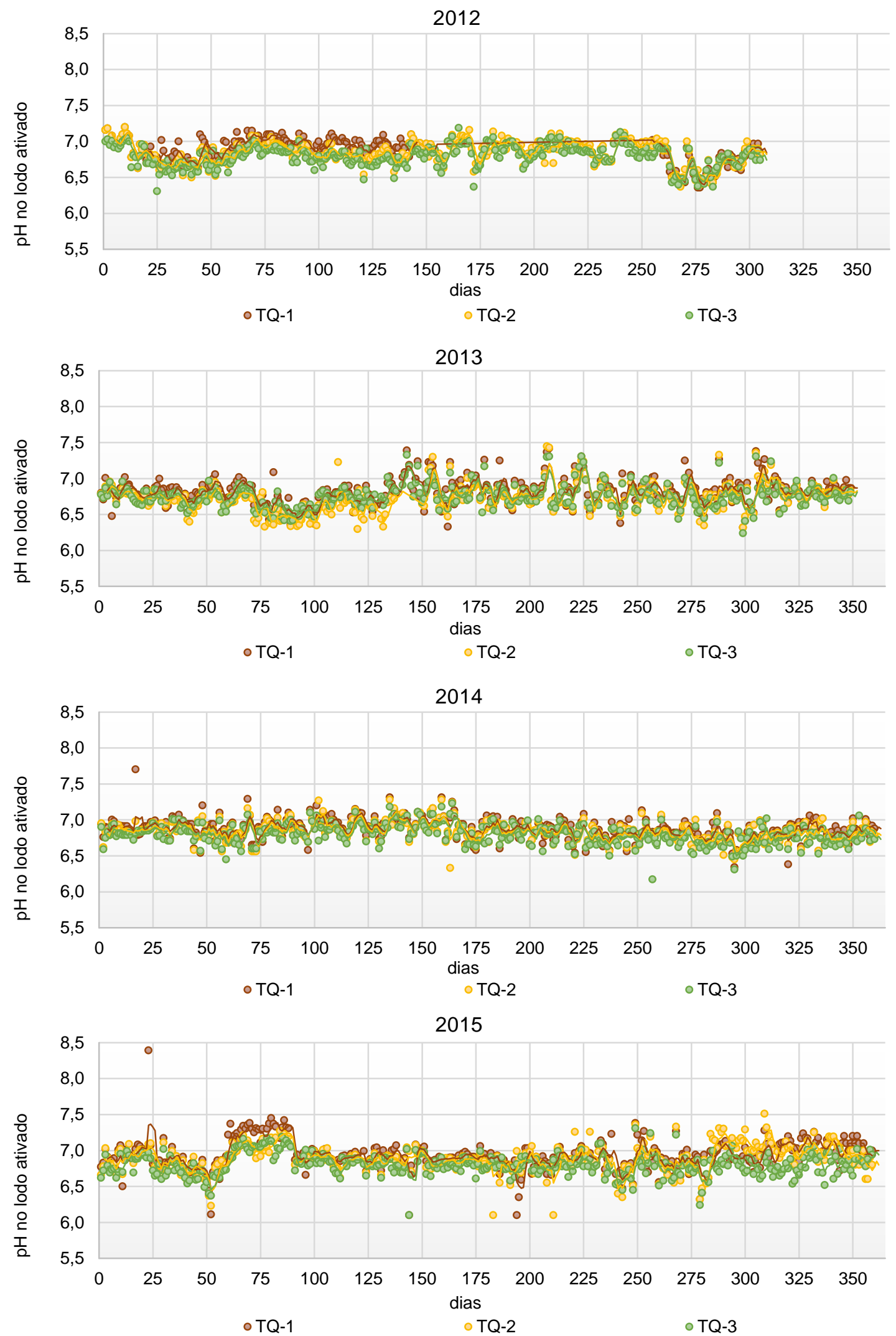
Tabela 31: Valores médios de pH nos tanques de aeração da ETE Limoeiro

\begin{tabular}{|c|c|c|c|c|c|c|}
\hline \multicolumn{7}{|c|}{$\mathrm{pH}$} \\
\hline \multirow{2}{*}{ Variável } & \multicolumn{3}{|c|}{2012} & \multicolumn{3}{|c|}{2013} \\
\hline & Tanque 01 & Tanque 02 & Tanque 03 & Tanque 01 & Tanque 02 & Tanque 03 \\
\hline Média & 6,87 & 6,84 & 6,80 & 6,81 & 6,87 & 6,76 \\
\hline Máximo & 7,20 & 7,20 & 7,19 & 7,42 & 7,45 & 7,33 \\
\hline Mínimo & 6,36 & 6,37 & 6,31 & 6,32 & 6,30 & 6,24 \\
\hline DP & 0,18 & 0,16 & 0,15 & 0,19 & 0,19 & 0,17 \\
\hline CV (\%) & 3,0 & 2,0 & 2,0 & 3,0 & 3,0 & 2,0 \\
\hline $\mathbf{N}$ & 203 & 305 & 305 & 336 & 327 & 336 \\
\hline
\end{tabular}

Tabela 32: Valores médios de pH nos tanques de aeração da ETE Limoeiro

\begin{tabular}{c|c|c|c|c|c|c}
\hline \multicolumn{7}{c}{ pH } \\
\hline \multirow{2}{*}{ Variável } & \multicolumn{3}{c}{$\mathbf{2 0 1 4}$} & \multicolumn{3}{c}{$\mathbf{2 0 1 5}$} \\
\cline { 2 - 7 } & Tanque 01 & Tanque 02 & Tanque 03 & Tanque 01 & Tanque 02 & Tanque 03 \\
\hline Média & 6,87 & 6,84 & 6,80 & 6,93 & 6,89 & 6,81 \\
\hline Máximo & 7,70 & 7,28 & 7,23 & 8,39 & 7,51 & 7,31 \\
\hline Mínimo & 6,34 & 6,33 & 6,17 & 6,10 & 6,10 & 6,10 \\
\hline DP & 0,15 & 0,14 & 0,14 & 0,22 & 0,19 & 0,16 \\
\hline CV (\%) & 2,0 & 2,0 & 2,0 & 3,0 & 3,0 & 2,0 \\
\hline $\mathbf{N}$ & 360 & 360 & 360 & 351 & 350 & 353 \\
\hline & & & & & &
\end{tabular}


Figura 68: Diagramas Box-Whiskers da pH nos tanques de aeração da ETE Limoeiro

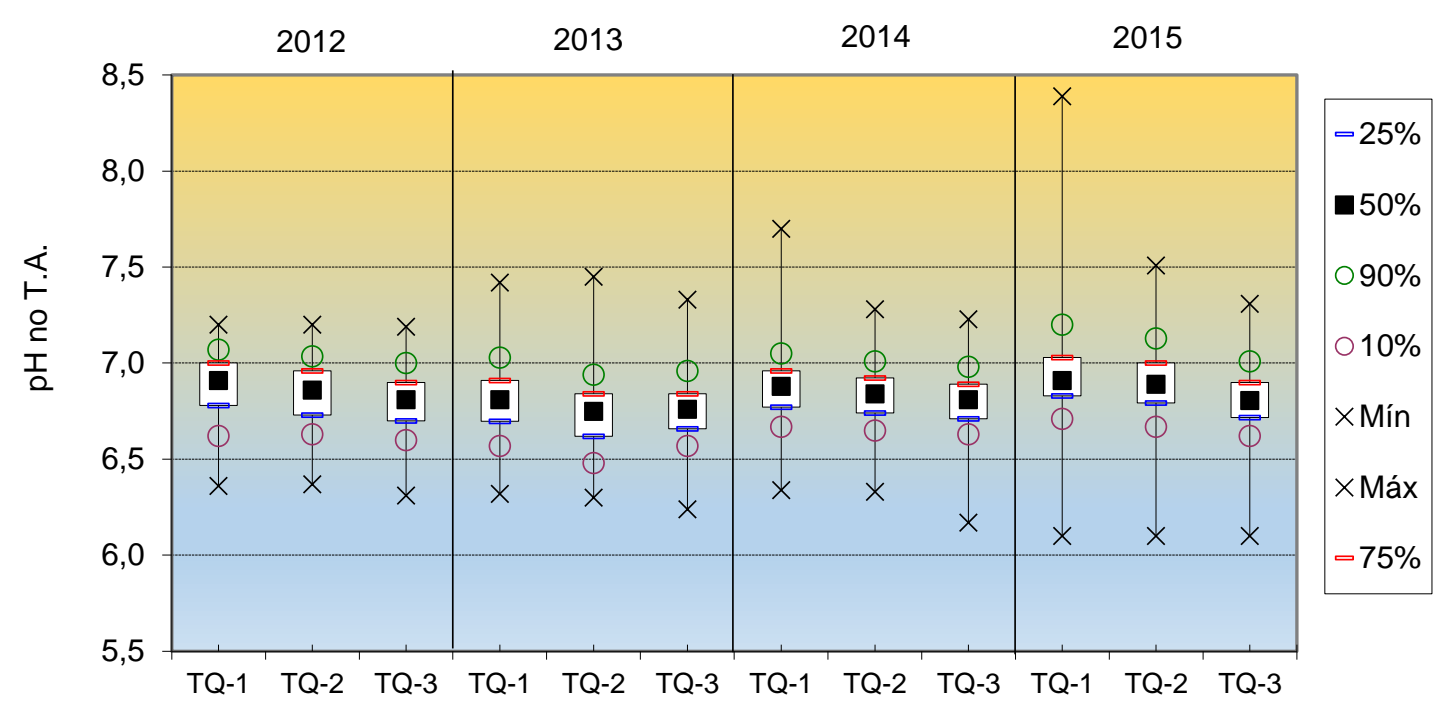

Observa-se que o pH do lodo ativado nos tanques de aeração ficou na faixa entre 6,3 a 7,2 para o ano de 2012, entre 6,2 a 7,5 no ano de 2013, entre 6,2 a 7,7 no ano de 2014 e de 6,1 a 8,4 para o ano de 2015, resultando em um pH médio nos lodos de 6 ,8. Na Figura 68, nota-se a dispersão dos resultados com quedas de $\mathrm{pH}$ um pouco mais acentuadas em todos os períodos, os resultados podem estar associados a um bom desempenho da nitrificação nesses períodos o que pode diminuir a desnitrificação no processo. De uma maneira geral, entende-se que o equilíbrio entre esses dois processos bioquímicos ocorreu de forma estável, com oscilações nos valores de $\mathrm{pH}$ ocorrendo em faixas aceitáveis.

\subsubsection{Potencial de oxirredução}

$\mathrm{Na}$ Figura 69, apresenta-se os resultados diários em série temporal com médias móveis de 4 termos do controle exercido sobre o potencial de oxirredução (ORP) dos lodos dos tanques de aeração. Esses valores correspondem à média das medições de ORP realizada e registrada a cada segundo diariamente durante o período de estudo e são lançados em forma de média na Tabela 33 e em gráfico de Box-Whiskers na Figura 70. 
Figura 69: ORP no lodo dos tanques de aeração da ETE Limoeiro
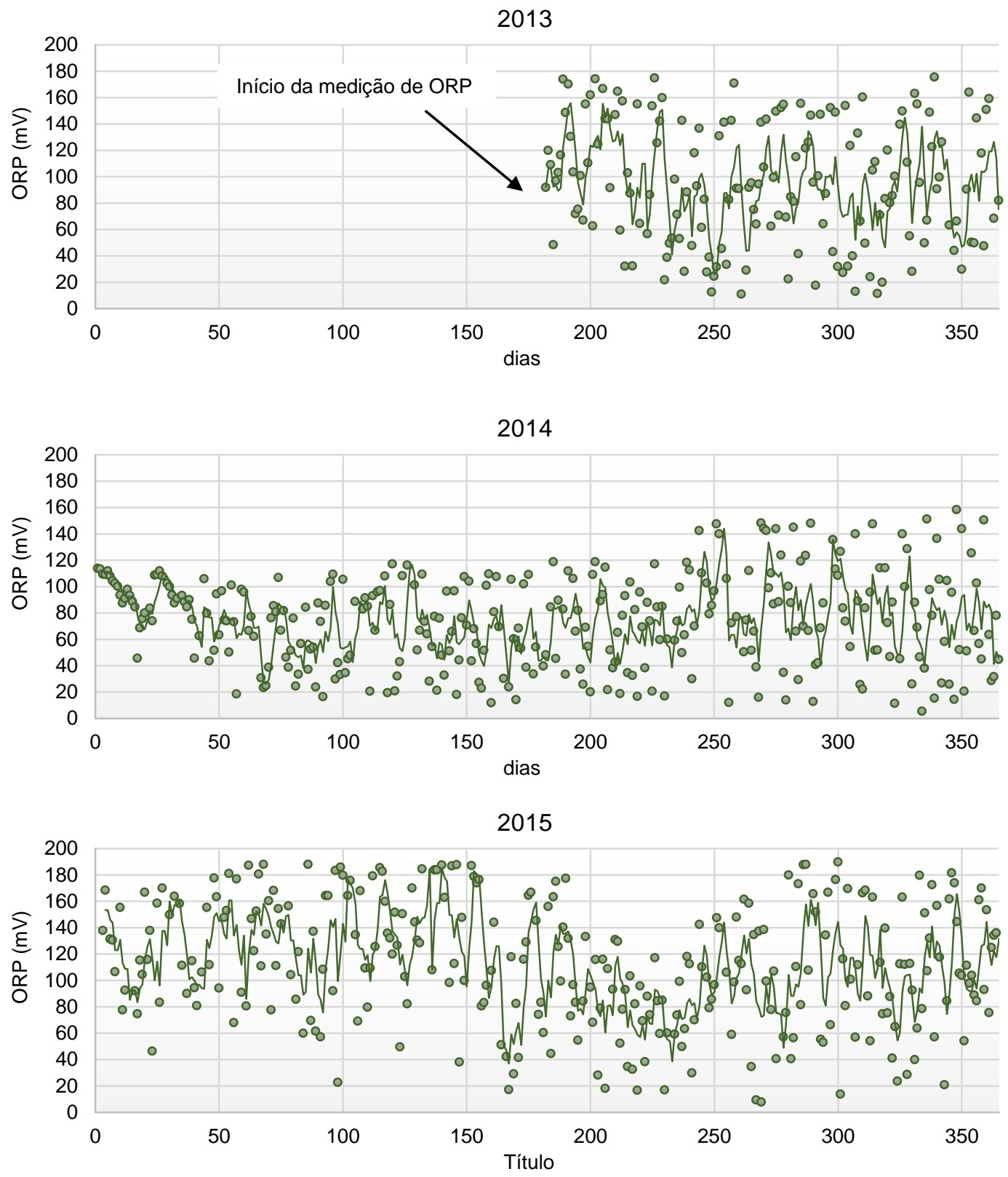

Tabela 33: valores do ORP no lodo dos tanques de aeração da ETE Limoeiro

\begin{tabular}{c|c|c|c}
\hline \multirow{2}{*}{ Variável } & \multicolumn{3}{|c}{ Monitoramento Online } \\
\cline { 2 - 4 } & $\mathbf{2 0 1 3}$ & $\mathbf{2 0 1 4}$ & $\mathbf{2 0 1 5}$ \\
\hline média & 95 & 74 & 113 \\
\hline máximo & 176 & 158 & 190 \\
\hline mínimo & 11 & 5 & 8 \\
\hline DP & 46 & 35 & 46 \\
\hline CV (\%) & 49 & 47 & 41 \\
\hline $\mathbf{n}$ & 161 & 317 & 295 \\
\hline
\end{tabular}


Figura 70: Diagramas Box-Whiskers do ORP no lodo dos tanques de aeração

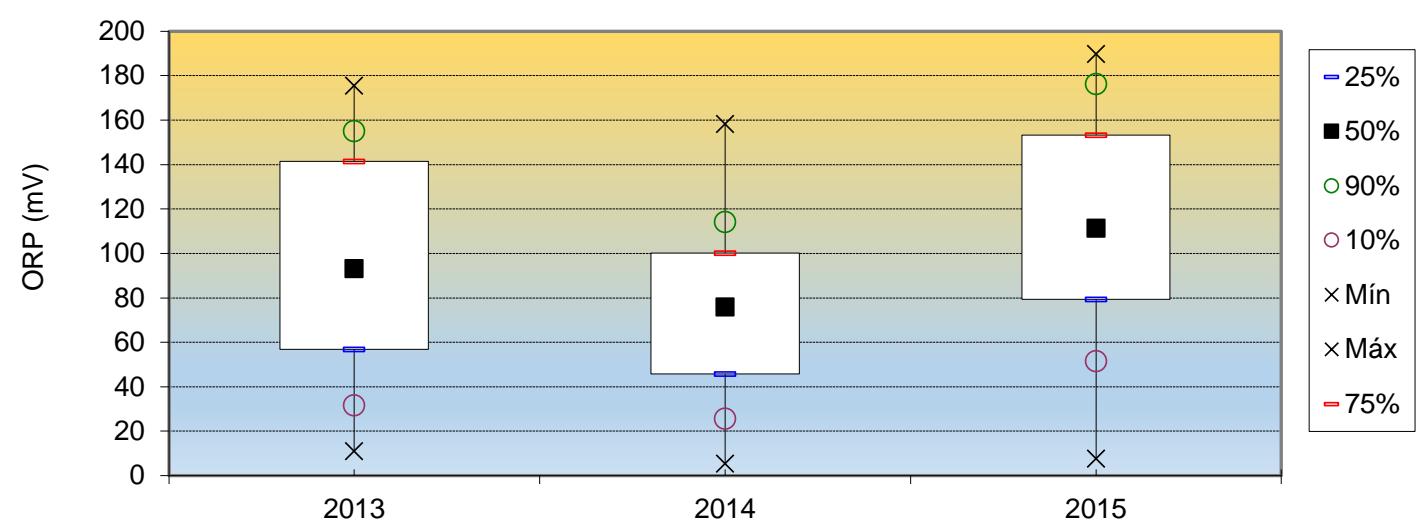

Os valores obtidos de ORP oscilaram entre $+5 \mathrm{a}+190 \mathrm{mV}$ no período de estudo e, resultaram valores médios de 95, 74 e 113 mV nos anos de 2013, 2014 e 2015, respectivamente. Valores semelhantes foram descritos por (ZHAO, H. W., et al., 1999; D. THAURÉ, et al., 2008 e BUENO, 2011), quando operaram sistemas promovendo a NDS. Quando se aplica o teste estatístico de correlação de Pearson aos dados obtidos de OD e ORP, nota-se uma correlação positiva baixa $r=(+0,10$ a 0,29$)$. Neste caso, é de interesse o uso do potencial de oxirredução como complemento na monitoração do processo de NDS. Porém não descarta a necessidade do monitoramento do OD no tanque de aeração.

\subsection{Remoção de Material Orgânico}

\subsubsection{Resultados da DBO no esgoto à entrada e à saída do processo de lodos ativados}

A Figura 71 apresenta os resultados com médias móveis de 4 termos de concentração de DBO do esgoto à entrada e à saída do processo de lodos ativados, esses valores correspondem a médias das determinações compostas realizadas durante o estudo. Esses resultados são lançados em formas de média nas Tabelas 34, 35, 36 e 37 e na Figura 72, onde observa-se a dispersão dos resultados em forma de gráficos BoxWhiskers. 
Figura 71: Série temporal das concentrações de DBO à entrada e à saída do processo de lodos ativados
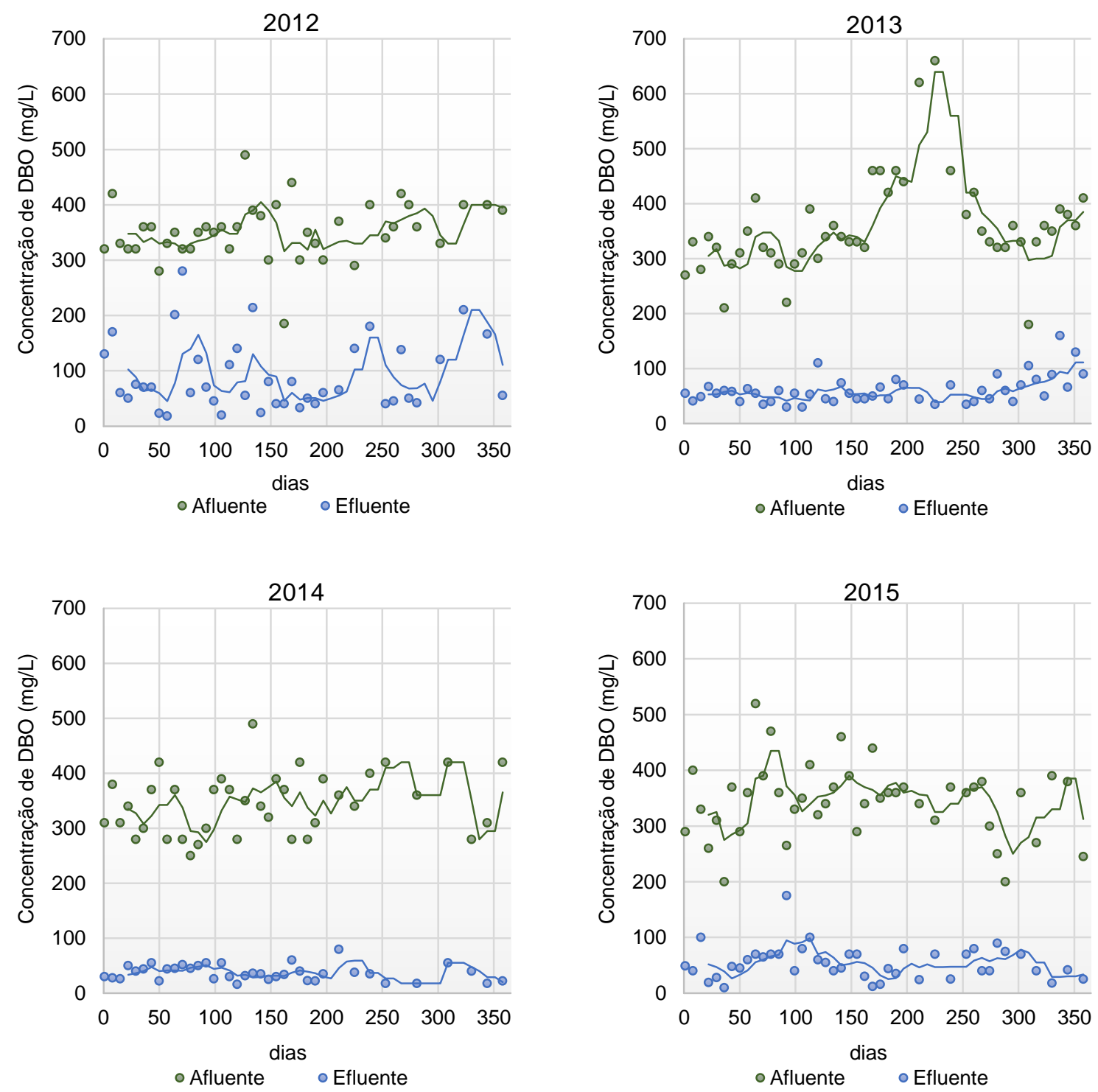

Tabela 34: Concentrações médias de DBO no processo de lodos ativados (2012)

\begin{tabular}{ccccc|cc}
\hline & \multicolumn{3}{c|}{ Afluente } & \multicolumn{2}{c}{ Eficiência } \\
\cline { 2 - 8 } Variável & \multicolumn{3}{c|}{ DBO (mg/L) } & \multicolumn{2}{c}{ (\%) } \\
& $\mathbf{( T )}$ & $\mathbf{( S )}$ & $\mathbf{( T )}$ & $\mathbf{( S )}$ & $\mathbf{( T )}$ & $\mathbf{( S )}$ \\
\hline média & 353 & 170 & 90 & 42 & 74,6 & 76,4 \\
\hline máximo & 490 & 264 & 280 & 119 & 94,5 & 98,6 \\
\hline mínimo & 185 & 77 & 18 & 2 & 12,5 & 30,3 \\
\hline DP & 51 & 49 & 63 & 34 & 17,7 & 19 \\
\hline CV (\%) & 15,0 & 29,0 & 71,0 & 80,0 & 20,0 & 20,0 \\
\hline $\mathbf{n}$ & \multicolumn{3}{c}{41} & & \multicolumn{3}{c}{41} \\
\hline
\end{tabular}

Legenda: (T) total e (S) solúvel 
Tabela 35: Concentrações médias de DBO no processo de lodos ativados (2013)

\begin{tabular}{ccccc|cc}
\hline \multirow{2}{*}{ Variável } & \multicolumn{3}{c|}{ Afluente } & \multicolumn{3}{c}{ Eficiência } \\
\cline { 2 - 8 } & \multicolumn{3}{c|}{ DBO (mg/L) } & \multicolumn{3}{c}{ (\%) } \\
\cline { 2 - 8 } & $\mathbf{( T )}$ & $\mathbf{( S )}$ & $\mathbf{( T )}$ & $\mathbf{( S )}$ & $\mathbf{( T )}$ & $\mathbf{( S )}$ \\
\hline média & 356 & 222 & 61 & 28 & 80,8 & 85,0 \\
\hline máximo & 660 & 508 & 160 & 69 & 94,7 & 96,8 \\
\hline mínimo & 180 & 72 & 30 & 9 & 41,8 & 51,4 \\
\hline DP & 86 & 80 & 26 & 12 & 10,0 & 10,0 \\
\hline CV (\%) & 24,0 & 36,0 & 42,0 & 43,0 & 10,0 & 9,1 \\
\hline $\mathbf{n}$ & \multicolumn{3}{c}{48} & & \multicolumn{3}{c}{48} \\
\hline
\end{tabular}

Legenda: (T) total e (S) solúvel

Tabela 36: Concentrações médias de DBO no processo de lodos ativados (2014)

\begin{tabular}{ccccc|cc}
\hline \multirow{2}{*}{ Variável } & \multicolumn{3}{c|}{ Afluente } & \multicolumn{2}{c|}{ Eficiência } \\
\cline { 2 - 8 } & \multicolumn{3}{c}{ DBO (mg/L) } & \multicolumn{3}{c}{$(\%)$} \\
\hline média & $\mathbf{( T )}$ & $\mathbf{( S )}$ & $\mathbf{( T )}$ & $\mathbf{( S )}$ & $\mathbf{( T )}$ & $\mathbf{( S )}$ \\
\hline máximo & 345 & 207 & 37 & 15 & 89,3 & 92,3 \\
\hline mínimo & 490 & 326 & 80 & 39 & 95,7 & 99,2 \\
\hline $\mathbf{D P}$ & 250 & 106 & 16 & $<5,0$ & 77,8 & 80,7 \\
\hline $\mathbf{C V}(\%)$ & 56 & 61 & 14 & 9 & 5,0 & 5,0 \\
\hline $\mathbf{n}$ & 16,0 & 29,0 & 39,0 & 61,0 & 10,0 & 10,0 \\
\hline
\end{tabular}

Legenda: (T) total e (S) solúvel

Tabela 37: Concentrações médias de DBO no processo de lodos ativados (2015)

\begin{tabular}{ccccc|ccc}
\hline \multirow{2}{*}{ Variável } & \multicolumn{2}{c|}{ Afluente } & \multicolumn{3}{c|}{ Eficiência } \\
\cline { 2 - 8 } & \multicolumn{3}{c}{ DBO (mg/L) } & \multicolumn{3}{c}{ (\%) } \\
\cline { 2 - 8 } & $\mathbf{( T )}$ & $\mathbf{( S )}$ & $\mathbf{( T )}$ & $\mathbf{( S )}$ & $\mathbf{( T )}$ & $\mathbf{( S )}$ \\
\hline média & 345 & 196 & 54 & 24 & 82,7 & 85,4 \\
\hline máximo & 520 & 329 & 175 & 93 & 97,3 & 98,6 \\
\hline mínimo & 200 & 82 & 10 & $<5,0$ & 34,0 & 30,6 \\
\hline $\mathbf{D P}$ & 66 & 67 & 30 & 21,6 & 12 & 17 \\
\hline CV (\%) & 19,0 & 34,0 & 56,0 & 90,0 & 10,0 & 20,0 \\
\hline $\mathbf{n}$ & \multicolumn{3}{c}{43} & \multicolumn{3}{c}{43} \\
\hline
\end{tabular}

Legenda: (T) total e (S) solúvel 
Figura 72: Diagramas Box-Whiskers - DBO e Eficiências afluente e efluente do processo de lodos ativados
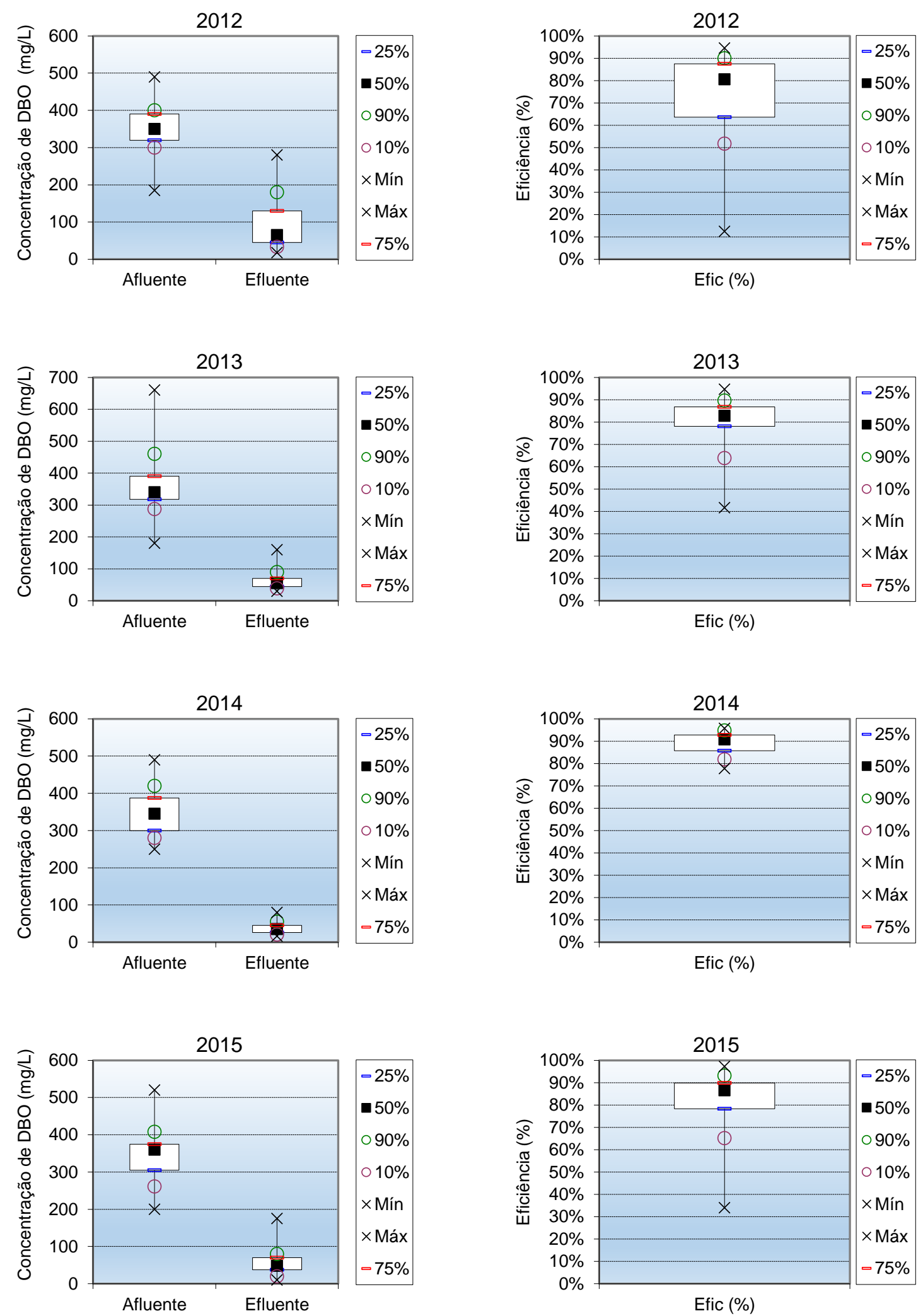
Observa-se que as concentrações de DBO à entrada e à saída do processo de lodos ativados no ano de 2012 ficaram na faixa de 185 a $490 \mathrm{mg} / \mathrm{L}$ e 18 a $280 \mathrm{mg} / \mathrm{L}$, respectivamente. Esses valores resultaram em uma eficiência média de $74,6 \%$ no período, valor considerado inferior à que ocorre normalmente em processos de lodos ativados. Esse fato está relacionado ao processo de perda excessiva de sólidos em suspensão no efluente final. Nesse período a perda média de SST foi de $206 \mathrm{mg} / \mathrm{L}$. Tendo-se obtido a relação SSV/SST $=0,71$ no lodo ativado, a perda correspondente de SSV é de 206 x 0,71 = $146 \mathrm{mg} / \mathrm{L}$. Para lodos ativados, prevê-se as razões $\mathrm{DBO}_{5} / \mathrm{SS}$ $\sim 0,5$, portanto, seriam previstas para o efluente final as concentrações de $\mathrm{DBO}_{5}$ de $73 \mathrm{mg} / \mathrm{L}$, o que não foi alcançado, observa-se na Tabela 34 o valor médio de $90 \mathrm{mg} / \mathrm{L}$ de $\mathrm{DBO}_{5}$ no efluente final. No ano de 2013 e mais efetivamente nos anos de $2014 \mathrm{e}$ 2015, o processo de lodos ativados passou a ter um maior controle operacional, devido a instalação dos controladores/sensores e com a retirada de sólidos adequada devido a aquisição de uma centrifuga de maior capacidade. Os resultados apresentados nas Tabelas 35, 36 e 37 mostram uma melhora na qualidade do efluente final. As eficiências médias nos períodos foram de $81,89,83 \%$, para os anos de 2013 , 2014 e 2015, respectivamente. A Figura 72 mostra a dispersão dos resultados obtidos no período do estudo, observa-se no Box-Whiskers valores medianos de 83, 93, 90\% de eficiência, para os anos de 2013, 2014 e 2015, valores superiores à média. Isto significa que o sistema teve remoção de DBO dentro da faixa esperada de um processo convencional de lodos ativados e que a baixa concentração de OD não afetou negativamente a remoção desse composto.

\subsubsection{Resultados da DQO no esgoto à entrada e à saída do processo de lodos ativados}

A Figura 73 apresenta os resultados com médias móveis de 4 termos de concentração de $\mathrm{DQO}$ do esgoto à entrada e à saída do processo de lodos ativados, esses valores correspondem a médias das determinações compostas realizadas durante o estudo. Esses resultados são lançados em formas de média nas Tabelas 38, 39, 40 e 41 e na Figura 74, onde observa-se a dispersão dos resultados em forma de gráficos BoxWhiskers. 
Figura 73: Série temporal das concentrações de DQO à entrada e à saída do processo de lodos ativados
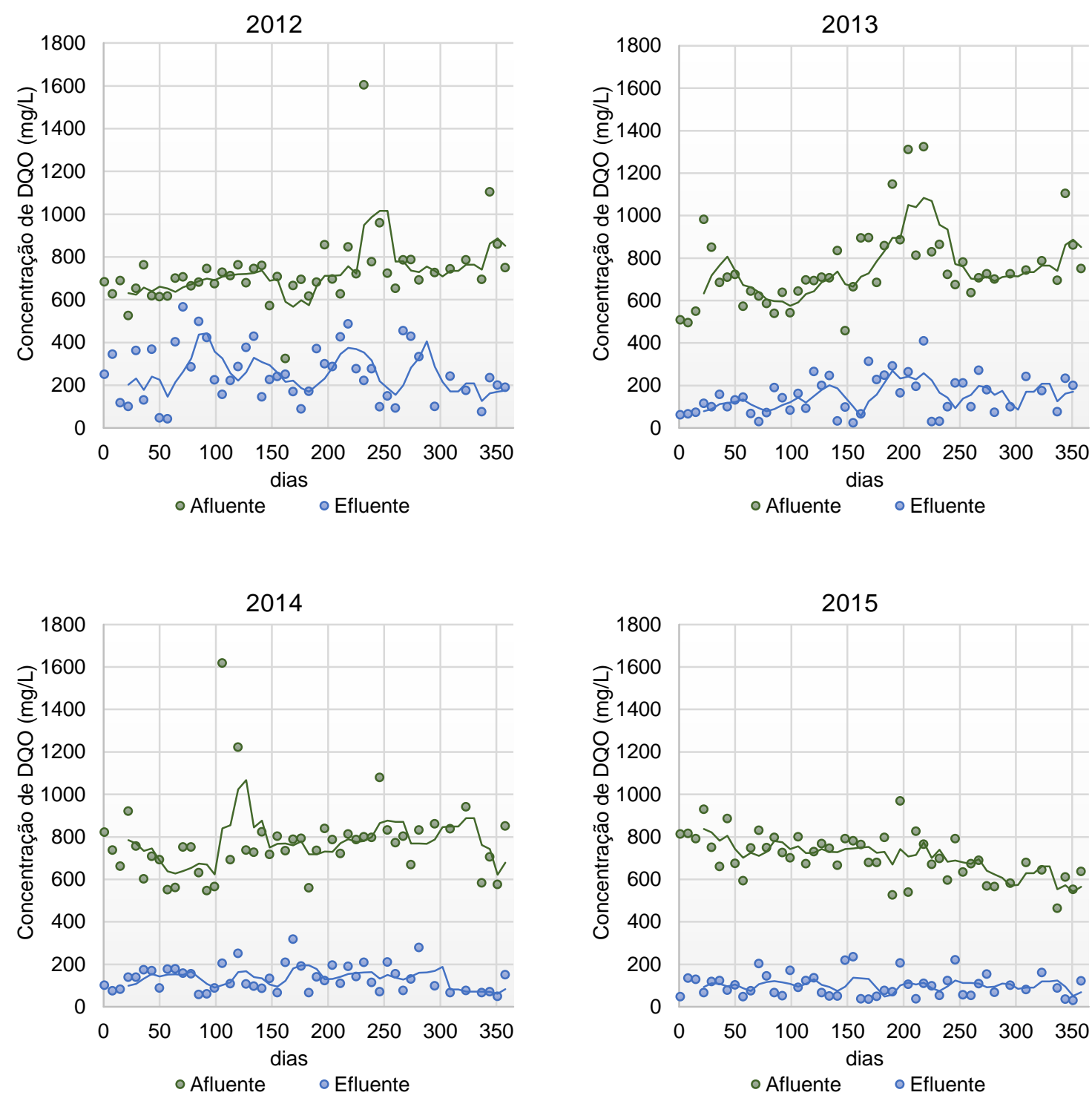
Tabela 38: Concentrações médias de DQO no processo de lodos ativados (2012)

\begin{tabular}{|c|c|c|c|c|c|c|}
\hline \multirow{3}{*}{ Variável } & \multicolumn{2}{|c|}{ Afluente } & \multicolumn{2}{|c|}{ Efluente } & \multicolumn{2}{|c|}{ Eficiência } \\
\hline & \multicolumn{4}{|c|}{$\mathrm{DQO}$ (mg/L) } & \multicolumn{2}{|c|}{$(\%)$} \\
\hline & (T) & (S) & $(\mathrm{T})$ & (S) & (T) & (S) \\
\hline média & 729 & 340 & 257 & 128 & 60,9 & 59,1 \\
\hline máximo & 1604 & 802 & 566 & 283 & 93,2 & 91,8 \\
\hline mínimo & 324 & 99 & 42 & 12 & 19,8 & 1,5 \\
\hline DP & 171 & 121 & 131 & 75 & 20,1 & 26,6 \\
\hline CV (\%) & 23,0 & 35,6 & 51,0 & 58,0 & 30,0 & 40,0 \\
\hline & \multicolumn{4}{|c|}{48} & \multicolumn{2}{|c|}{48} \\
\hline
\end{tabular}

Legenda: (T) total e (S) solúvel

Tabela 39: Concentrações médias de DQO no processo de lodos ativados (2013)

\begin{tabular}{ccccc|cc}
\hline \multirow{2}{*}{ Variável } & \multicolumn{2}{c}{ Afluente } & \multicolumn{2}{c}{ Efluente } & \multicolumn{2}{c}{ Eficiência } \\
\cline { 2 - 8 } & \multicolumn{3}{c}{ DQO (mg/L) } & \multicolumn{2}{c}{ (\%) } \\
\cline { 2 - 8 } & $\mathbf{( T )}$ & $\mathbf{( S )}$ & $\mathbf{( T )}$ & $\mathbf{( S )}$ & $\mathbf{( T )}$ & $\mathbf{( S )}$ \\
\hline média & 753 & 348 & 151 & 79 & 80,5 & 75,7 \\
\hline máximo & 1323 & 814 & 410 & 209 & 61,6 & 97,3 \\
\hline mínimo & 458 & 160 & 24 & 13 & 96,4 & 23,4 \\
\hline DP & 185 & 114 & 88,1 & 52 & 10,4 & 16,4 \\
\hline CV (\%) & 25,0 & 33,0 & 58,0 & 65,0 & 10,0 & 20,0 \\
\hline $\mathbf{n}$ & \multicolumn{2}{c}{48} & & \multicolumn{3}{c}{48} \\
\hline
\end{tabular}

Legenda: (T) total e (S) solúvel; * Não realizado.

Tabela 40: Concentrações médias de DQO no processo de lodos ativados (2014)

\begin{tabular}{ccccc|cc}
\hline \multirow{2}{*}{ Variável } & \multicolumn{2}{c}{ Afluente } & \multicolumn{2}{c|}{ Efluente } & \multicolumn{2}{c}{ Eficiência } \\
\cline { 2 - 8 } & \multicolumn{3}{c}{ DQO (mg) } & (\%) \\
\cline { 2 - 8 } & $\mathbf{( T )}$ & $\mathbf{( S )}$ & $\mathbf{( T )}$ & $\mathbf{( S )}$ & $\mathbf{( T )}$ & $\mathbf{( S )}$ \\
\hline média & 772 & 345 & 133 & 54 & 81,2 & 83,7 \\
\hline máximo & 1618 & 971 & 317 & 116 & 93,5 & 95,7 \\
\hline mínimo & 546 & 100 & 48 & 15 & 60,0 & 59,8 \\
\hline DP & 180 & 143 & 62 & 30 & 8,0 & 8,3 \\
\hline CV (\%) & 23,0 & 41,0 & 46,0 & 56,0 & 10,0 & 10,0 \\
\hline $\mathbf{n}$ & \multicolumn{3}{c}{48} & \multicolumn{3}{c}{48} \\
\hline
\end{tabular}

Legenda: (T) total e (S) solúvel

Tabela 41: Concentrações médias de DQO no processo de lodos ativados (2015)

\begin{tabular}{ccccc|cc}
\hline \multirow{2}{*}{ Variável } & \multicolumn{3}{c|}{ Afluente } & \multicolumn{2}{c}{ Eficiência } \\
\cline { 2 - 8 } & \multicolumn{3}{c}{ DQO (mg/L) } & \multicolumn{2}{c}{$(\%)$} \\
\hline média & $\mathbf{( T )}$ & $\mathbf{( S )}$ & $\mathbf{( T )}$ & $\mathbf{( S )}$ & $\mathbf{( T )}$ & $\mathbf{( S )}$ \\
\hline máximo & 708 & 304 & 100 & 43 & 86,0 & 85,9 \\
\hline mínimo & 968 & 516 & 234 & 111 & 95,6 & 95,6 \\
\hline DP & 463 & 85 & 29 & 8 & 70,0 & 69,0 \\
\hline CV (\%) & 106 & 109 & 54 & 28 & 7,2 & 7,2 \\
\hline $\mathbf{n}$ & 15,0 & 36,0 & 55,0 & 67,0 & 10,0 & 10,0 \\
\hline
\end{tabular}

Legenda: (T) total e (S) solúvel; * Não realizado. 
Figura 74: Diagramas Box-Whiskers - DQO e Eficiências afluente e efluente do processo de lodos ativados
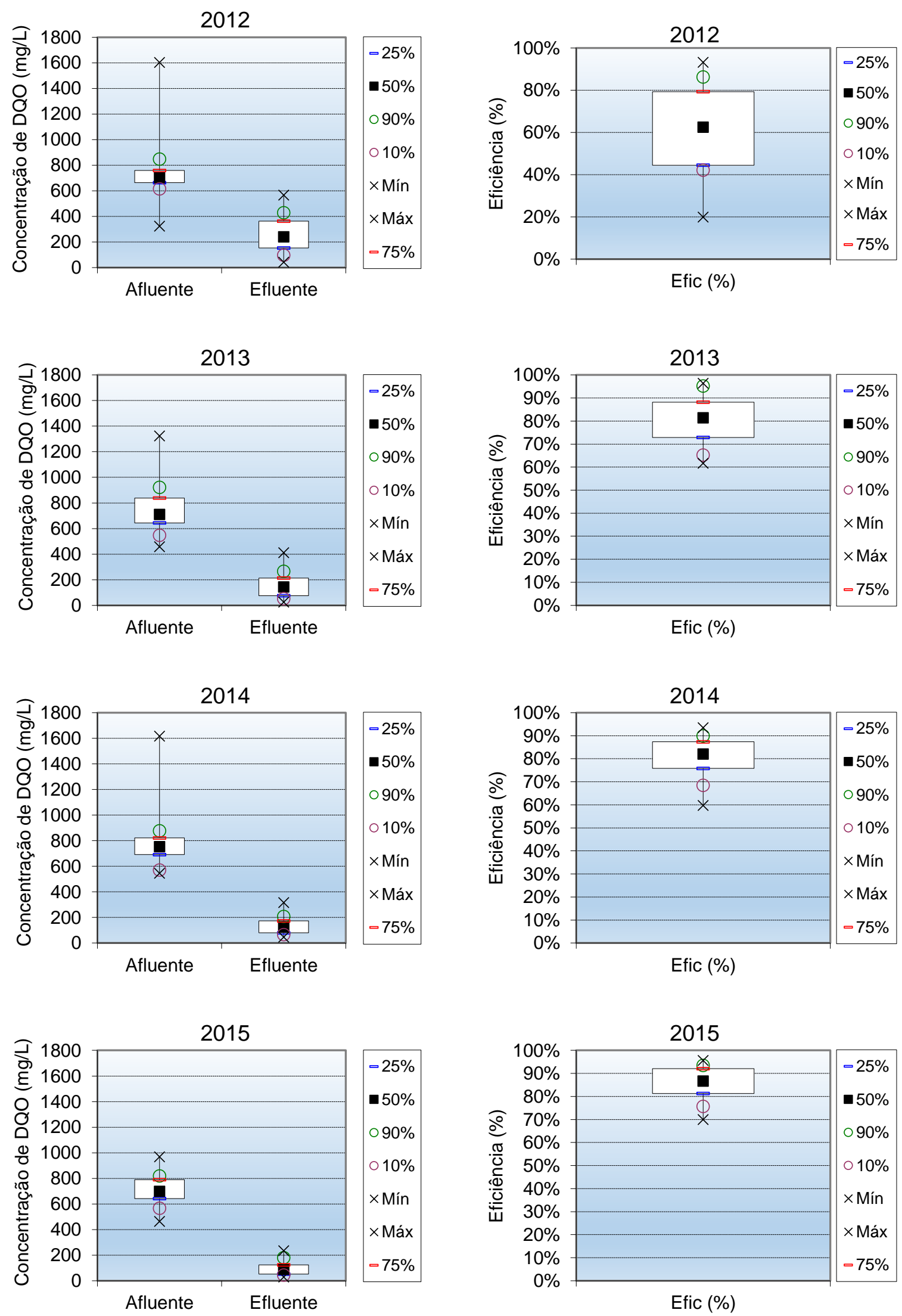
Observa-se que a relação entre a DQO solúvel e a DQO total manteve-se muito próxima a 0,5 durante os anos de 2012 e 2013 e de 0,4 nos anos de 2014 e 2015, tanto no afluente como no efluente do processo de lodos ativados. Isto significa que, apesar da parcela significativa no esgoto afluente de material que pode ser metabolizado mais facilmente, o processo de tratamento não resultou na melhor floculação possível da matéria coloidal do esgoto, tendo resultado em fração solúvel ainda elevada, paralelamente ao processo de perda excessiva de sólidos em suspensão no efluente. No ano de 2012 a perda média de SST foi de $206 \mathrm{mg} / \mathrm{L}$. Tendo-se obtido a relação SSV/SST $=0,71$ no lodo ativado, a perda correspondente de SSV é de 206 x 0,71 = $146 \mathrm{mg} / \mathrm{L}$. Para lodos ativados, prevê-se as razões DQO/SS $\sim 1,5$, portanto, seriam previstas para o efluente final as concentrações de DQO de $219 \mathrm{mg} / \mathrm{L}$, o que não foi alcançado, observa-se na Tabela 38 o valor médio de 257 $\mathrm{mg} / \mathrm{L}$ de $\mathrm{DQO}$ no efluente final.

No ano de 2013, mais efetivamente nos anos de 2014 e 2015, o processo de lodos ativados passou a ter um maior controle operacional, devido a instalação dos controladores/sensores e retirada de sólidos constantes, devido a aquisição de uma centrifuga de maior capacidade. Os resultados apresentados nas Tabelas 39, 40 e 41 mostram uma melhora na qualidade do efluente final. As eficiências médias nos períodos foram de $81,81,86 \%$, para os anos de 2013, 2014 e 2015, respectivamente. Embora o processo de lodos ativados operando com nitrificação e desnitrificação simultânea tenha resultado em boas eficiências de remoção em termos de DQO, a qualidade do efluente final pode ser considerada inferior à que normalmente ocorre em processos de lodos ativados com aeração prolongada.

\subsubsection{Balanço de Massa do Material Orgânico}

Para o cálculo do balanço de massa do material orgânico foi necessário à realização da determinação da TCO total "in loco" $\left(\mathrm{TCO}_{\mathrm{t}}\right)$ no processo de lodos ativados. Para tanto, foi retirado uma alíquota do conteúdo do tanque de aeração e, imediatamente, executado o ensaio respirométrico, ou seja, foram feitas medidas de TCO até que se atingia a fase endógena ( $\mathrm{TCO}_{\mathrm{end}}$ ). Uma vez obtido os valores referentes à $\mathrm{TCO}_{\mathrm{t}}$ e de posse dos valores da TCO nitrogenada (TCOn), foi possível determinar, por diferença, 
a TCO correspondente a oxidação do material orgânico ( $\left.\mathrm{TCO}_{\mathrm{c}}\right)$, e assim obter-se o balanço de massa.

Por exemplo, para o ano de 2015, tem-se:

$\mathrm{TCO}_{c}=\mathrm{TCO}_{\mathrm{t}}-\mathrm{TCO}_{\mathrm{n}}-\mathrm{TCO}_{\mathrm{end}}=71-27-14=30 \mathrm{mgO}_{2} \mathrm{~L}^{-1} \cdot \mathrm{h}^{-1}$

Em que:

TCOc: taxa de consumo de oxigênio devido a oxidação de material orgânico;

TCOn: taxa de consumo de oxigênio devido a nitrificação e

TCOt: taxa de consumo de oxigênio total ou exógena.

Nas Tabelas 42 e 43 apresentam-se os resultados das determinações da taxa de consumo de oxigênio (TCO) "in loco" no sistema de lodo ativado.

Tabela 42: Taxa de consumo de oxigênio no lodo durante as

\begin{tabular}{|c|c|c|c|c|c|c|c|c|}
\hline \multicolumn{9}{|c|}{ Taxa de consumo de oxigênio $\left(\mathrm{mgO}_{2} / \mathrm{L} / \mathrm{h}\right)$} \\
\hline \multirow{2}{*}{ Variáveis } & \multicolumn{4}{|c|}{2012} & \multicolumn{4}{|c|}{2013} \\
\hline & $\mathrm{TCO}_{\mathrm{t}}$ & $\mathrm{TCO}_{\text {end }}$ & $\mathrm{TCO}_{\mathrm{n}}$ & $\mathrm{TCO}_{\mathrm{c}}$ & $\mathrm{TCO}_{\mathrm{t}}$ & $\mathrm{TCO}_{\text {end }}$ & $\mathrm{TCO}_{\mathrm{n}}$ & $\mathrm{TCO}_{\mathrm{c}}$ \\
\hline média & 70 & 25 & 19 & 26 & 77 & 16 & 27 & 34 \\
\hline máximo & 88 & 32 & 26 & 30 & 118 & 18 & 52 & 48 \\
\hline mínimo & 52 & 22 & 11 & 19 & 39 & 8 & 18 & 13 \\
\hline DP & 12,7 & 3,5 & 5,1 & 5,6 & 18,5 & 3,9 & 9,9 & 17,6 \\
\hline CV (\%) & 18,0 & 14,3 & 27,4 & 21,4 & 24 & 24,5 & 36,2 & 51,8 \\
\hline $\mathbf{n}$ & \multicolumn{4}{|c|}{20} & \multicolumn{4}{|c|}{19} \\
\hline
\end{tabular}

Tabela 43: Taxa de consumo de oxigênio no lodo durante as Etapas I e II.

\begin{tabular}{|c|c|c|c|c|c|c|c|c|}
\hline \multicolumn{9}{|c|}{ Taxa de consumo de oxigênio $\left(\mathrm{mgO}_{2} / \mathrm{L} / \mathrm{h}\right)$} \\
\hline \multirow{2}{*}{ Variáveis } & \multicolumn{4}{|c|}{2014} & \multicolumn{4}{|c|}{2015} \\
\hline & $\mathrm{TCO}_{\mathrm{t}}$ & $\mathrm{TCO}_{\text {end }}$ & $\mathrm{TCO}_{n}$ & $\mathrm{TCO}_{\mathrm{C}}$ & $\mathrm{TCO}_{\mathrm{t}}$ & $\mathrm{TCO}_{\text {end }}$ & $\mathrm{TCO}_{\mathrm{n}}$ & $\mathrm{TCO}_{\mathrm{c}}$ \\
\hline média & 72 & 14 & 25 & 33 & 71 & 14 & 27 & 30 \\
\hline máximo & 110 & 16 & 42 & 52 & 120 & 22 & 52 & 46 \\
\hline mínimo & 32 & 10 & 16 & 6 & 32 & 12 & 18 & 2 \\
\hline DP & 12,5 & 4,9 & 7,9 & 23,1 & 10,2 & 3,9 & 9,9 & 22,3 \\
\hline CV (\%) & 16,7 & 18,0 & 18,0 & 22,0 & 14,5 & 16,5 & 18 & 74,2 \\
\hline $\mathbf{n}$ & \multicolumn{4}{|c|}{15} & \multicolumn{4}{|c|}{15} \\
\hline
\end{tabular}

Ao analisar os resultados experimentais, pode-se notar que os valores médios da TCOt "in loco" (bactérias heterotróficas e autotróficas) foram semelhantes ao longo de todo o estudo, independente da variação da idade do lodo e da razão A/M. Com os resultados das Tabelas 42 e 43 e das determinações analíticas realizadas ao longo 
do estudo foi calculado o balanço de massa do material orgânico, nesse estudo foi adotado o modelo descrito em van Haandel e Marais, 1999.

Exemplificando-se, para o ano de 2015, tem-se:

Valores médios das determinações analíticas no período:

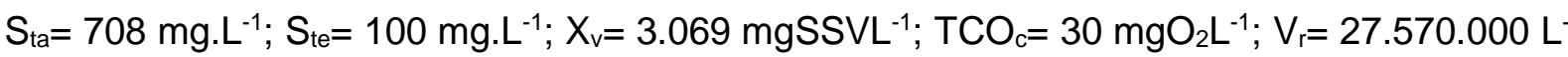
${ }^{1} ; Q_{a}=41.080 .435$ L.d. $^{-1} ; q=898.693{\mathrm{~L} . \mathrm{d}^{-1}}^{-1} \mathrm{f}_{\mathrm{cv}}=$ adotado $1,5 \mathrm{mgDQO} \mathrm{mgSSV}^{-1}$.

Portanto calcula-se:

Fração da DQO afluente descarregada no efluente $\left(m S_{t e}\right)$ :

$\mathrm{mS}_{\mathrm{te}}=\mathrm{S}_{\mathrm{te}} / \mathrm{S}_{\mathrm{ta}}=100 / 708=0,14$

Fração da DQO afluente descarregada como lodo de excesso $\left(\mathrm{mS}_{\mathrm{xv}}\right)$ : $m S_{\mathrm{xv}}=\left(\mathrm{q} / \mathrm{Q}_{\mathrm{a}}\right)^{*} \mathrm{f}_{\mathrm{cv}}{ }^{*} \mathrm{X}_{\mathrm{v}} / \mathrm{S}_{\mathrm{ta}}=(898.693 / 41.080 .435)^{*} 1,5^{*} 3.069 / 708=0,12$

Fração de DQO afluente que é oxidada no sistema ( $\left.\mathrm{mS}_{\mathrm{o}}\right)$ : $\mathrm{mS}_{\mathrm{o}}=\left(\mathrm{V}_{\mathrm{r}} / \mathrm{Q}_{\mathrm{a}}\right)^{*} \mathrm{TCO}_{\mathrm{c}}{ }^{*} 24 / \mathrm{S}_{\mathrm{ta}}=(27.570 .000 / 41.080 .435)^{*} 30^{*} 24 / 708=0,69$

A soma das três frações dá o valor do balanço de massa do material orgânico $\left(B_{0}\right)$ : $B_{o}=\left(m S_{t e}+m S_{x v}+m S_{o}\right)=(0,14+0,12+0,69)=0,95$

Portanto, em relação aos resultados do ano de 2015, o balanço de massa de material orgânico foi consistente, com $\mathrm{B}_{\circ}=0,95$, ou seja, com desvio de apenas $5 \%$. Na Tabela 44 apresenta-se os resultados do balanço de massa para o período de estudo. 
Tabela 44: Balanço de massa de material orgânico no processo de lodos ativados

\begin{tabular}{c|c|c|c|c}
\hline \multicolumn{6}{c}{ Balanço de massa do material orgânico } \\
\hline Variável & $\mathbf{2 0 1 2}$ & $\mathbf{2 0 1 3}$ & $\mathbf{2 0 1 4}$ & $\mathbf{2 0 1 5}$ \\
\hline Média & 1,39 & 1,06 & 1,06 & 0,95 \\
\hline máximo & 3,72 & 1,77 & 1,90 & 1,48 \\
\hline mínimo & 0,56 & 0,66 & 0,51 & 0,65 \\
\hline DP & 0,39 & 0,14 & 0,13 & 0,11 \\
\hline CV (\%) & 28,24 & 13,15 & 11,86 & 11,88 \\
\hline AT & 3,15 & 1,11 & 1,39 & 0,83 \\
\hline n & 305 & 304 & 320 & 330 \\
\hline
\end{tabular}

Constata-se que os valores médios tiveram boa aproximação ao valor teórico $B_{0}=1,0$ nos anos de 2013, 2014 e 2015, estando menos que 10\% distante desse resultado. Conclui-se que, em boa aproximação, o balanço de massa do material orgânico demonstrou-se consistente, com exceção do ano de 2012 (período inicial do estudo). Portanto os dados experimentais são confiáveis e o sistema de lodo ativado foi operado sob condições estacionárias (VAN HAANDEL e MARAIS,1999).

\subsection{Remoção de Nitrogênio}

$\mathrm{Na}$ Figura 75, apresenta-se os resultados da série temporal das determinações compostas de NKT e Nitrogênio Amoniacal no esgoto à entrada e à saída do processo de lodos ativados. Esses resultados são apresentados em forma estatística nas Tabelas 45 e 46 e, na Figura 76 em forma de gráficos de Box-Whiskers. 
Figura 75: Série temporal de NKT e N-Amoniacal afluente e efluente do processo de lodos ativados
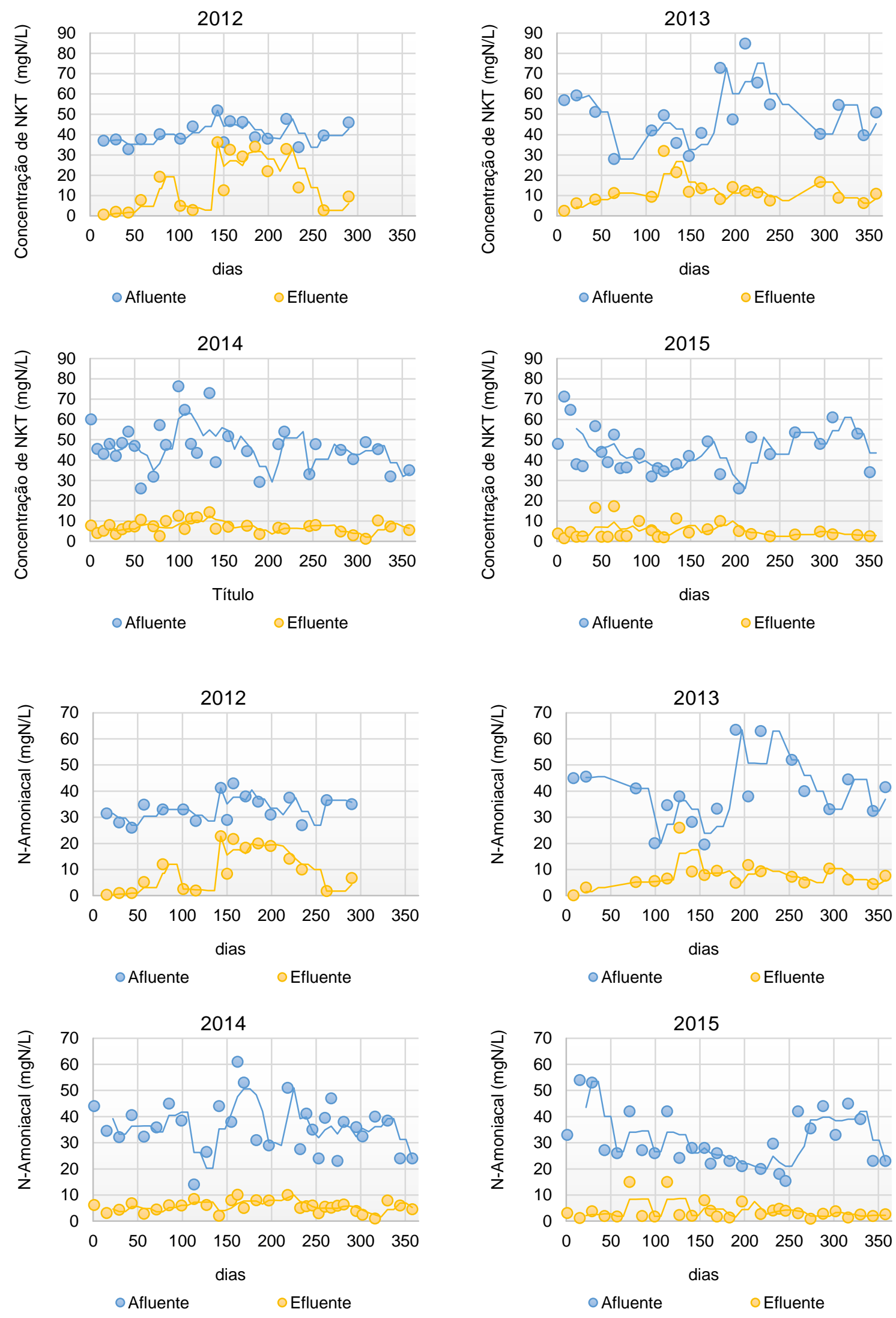
Tabela 45: Concentrações médias de NKT-N e N-Amoniacal no afluente e efluente do processo de lodos ativados

\begin{tabular}{c|c|c|c|c|c|c|c|c}
\hline Variável & \multicolumn{4}{|c|}{2012} & \multicolumn{4}{c}{$\mathbf{2 0 1 3}$} \\
\hline \multirow{2}{*}{ Variável } & \multicolumn{2}{|c|}{ Afluente } & \multicolumn{2}{c|}{ Efluente } & \multicolumn{2}{c}{ Afluente } & \multicolumn{2}{c}{ Efluente } \\
\cline { 2 - 9 } & $\mathbf{N K T}$ & $\mathbf{N H}_{3}{ }^{-}$ & $\mathbf{N K T}$ & $\mathbf{N H}_{3}{ }^{-}$ & $\mathbf{N K T}$ & $\mathbf{N H}_{3}{ }^{-}$ & $\mathbf{N K T}$ & $\mathbf{N H}_{3}{ }^{-}$ \\
\hline Média & 40,7 & 33,5 & 15,6 & 9,8 & 50,2 & 39,6 & 11,8 & 7,8 \\
\hline Máximo & 51,9 & 43,0 & 36,3 & 22,7 & 84,7 & 63,5 & 32,0 & 26,0 \\
\hline Mínimo & 32,8 & 26,0 & 0,7 & 0,3 & 28,0 & 19,6 & 2,5 & 0,1 \\
\hline DP & 5,4 & 4,9 & 13,1 & 8,1 & 14,6 & 12,0 & 6,6 & 5,3 \\
\hline CV (\%) & 13,0 & 15,0 & 84,0 & 83,0 & 29,0 & 30,0 & 56,0 & 69,0 \\
\hline $\mathbf{N}$ & \multicolumn{3}{|c|}{17} & \multicolumn{5}{c}{18} \\
\hline
\end{tabular}

Tabela 46: Concentrações médias de NKT-N e N-Amoniacal no afluente e efluente do processo de lodos ativados

\begin{tabular}{c|c|c|c|c|c|c|c|c}
\hline Variável & \multicolumn{4}{|c|}{2014} & \multicolumn{4}{c}{2015} \\
\hline \multirow{2}{*}{ Variável } & Afluente & \multicolumn{2}{c|}{ Efluente } & Afluente & \multicolumn{2}{c}{ Efluente } \\
\cline { 2 - 9 } & $\mathbf{N K T}$ & $\mathbf{N H}_{3}{ }^{-}$ & $\mathbf{N K T}^{-}$ & $\mathbf{N H}_{3}{ }^{-}$ & $\mathbf{N K T}$ & $\mathbf{N H}_{3}^{-}$ & $\mathbf{N K T}$ & $\mathbf{N H}_{3}{ }^{-}$ \\
\hline Média & 46,8 & 36,1 & 7,1 & 5,6 & 44,1 & 31,1 & 5,1 & 3,8 \\
\hline Máximo & 76,3 & 61,0 & 14,3 & 10,1 & 71,3 & 54,0 & 17,3 & 15,0 \\
\hline Mínimo & 26,0 & 14,0 & 1,3 & 1,0 & 26,0 & 15,4 & 1,5 & 0,9 \\
\hline DP & 11,5 & 9,9 & 3,0 & 2,2 & 10,9 & 10,4 & 4,2 & 3,6 \\
\hline CV (\%) & 25,0 & 27,0 & 42,0 & 40,0 & 25,0 & 33,0 & 82,0 & 94,0 \\
\hline $\mathbf{N}$ & \multicolumn{3}{|c|}{31} & & \multicolumn{7}{c}{28} \\
\hline
\end{tabular}


Figura 76: Diagramas Box-Whiskers de NKT e N-Amoniacal no afluente e efluente do processo de lodos ativados
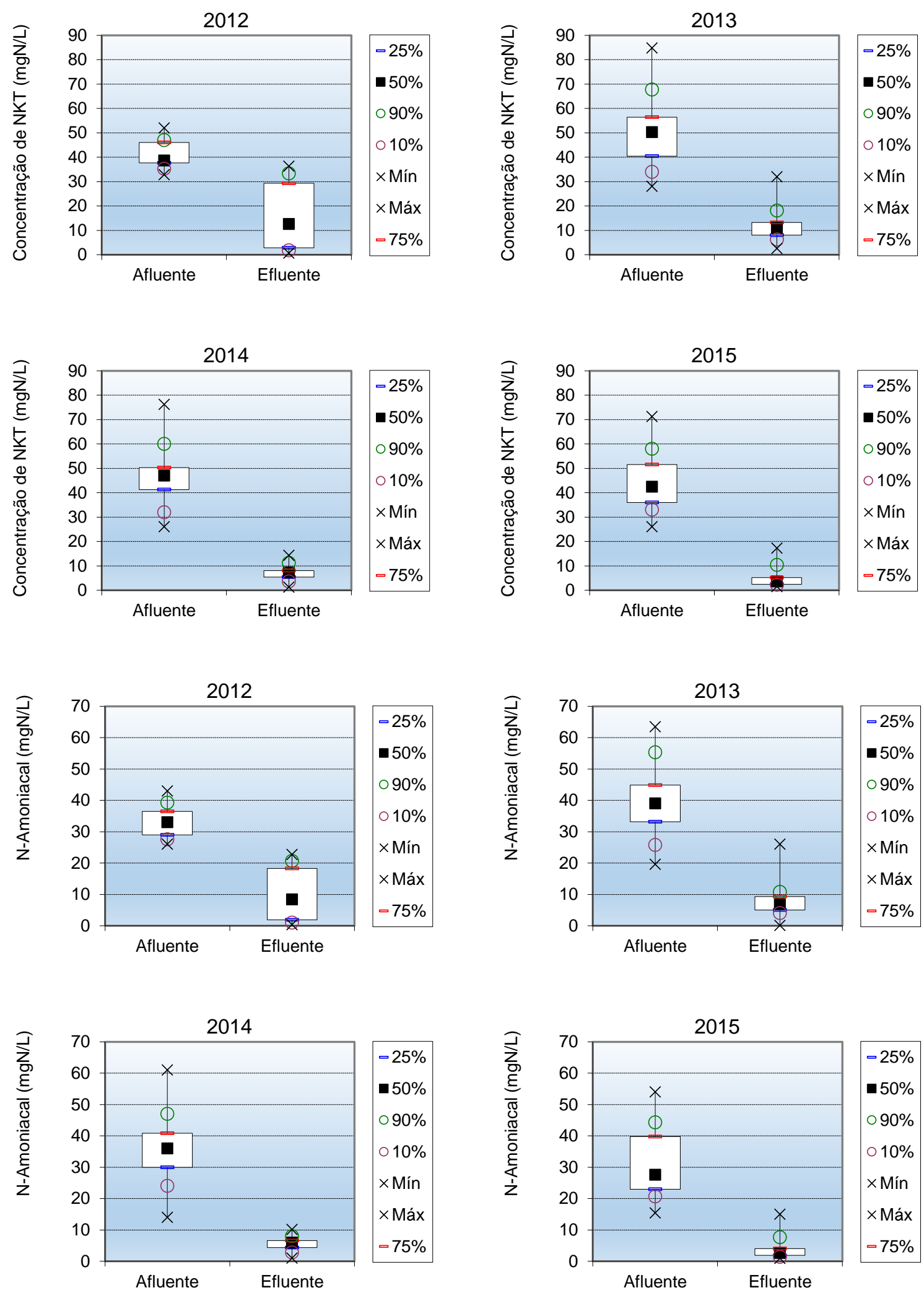
Os resultados demonstram que a nitrificação do esgoto ocorreu de forma eficiente, porém, não completa. As concentrações médias de NKT no efluente foram de 15,6, 11,8, 7,1 e 5,1 mgN-NKT/L e de Nitrogênio Amoniacal de 9,8, 7,8, 5,6 e 3,8 mgN$\mathrm{NH}_{3} / \mathrm{L}$ para os anos de 2012, 2013, 2014 e 2015, respectivamente. Nos anos de 2014 e 2015, período de melhor controle operacional, observa-se valores relativamente baixos no efluente final. No entanto, é comum em processos de lodos ativados com a mesma faixa de idade do lodo a obtenção de residuais da ordem de 2,0 mgN-NH $3 /$, porém, com maior concentração de OD nos tanques de aeração. Essa condição foi obtida no experimento em escala piloto, onde resultou um efluente final com rediaul de 2,1 $\mathrm{mgN}-\mathrm{NH}_{3} / \mathrm{L}$, resultados similares também são relatados nos estudos de (PENG ZHANG E ZHOU QI, 2007; THAURÉ et al., 2008; BUENO, 2011). O valor médio obtido no estudo em escala real requer diluição para lançamento em águas classe $2 \mathrm{da}$ Resolução 357/2005 do CONAMA. No entanto, ao serem observadas as séries históricas da Figura 75, pode-se identificar que o valor médio relativamente elevado encontrado se deve a episódios de maior prejuízo para a nitrificação. Isto pode ter ocorrido mediante substancial redução na idade do lodo ocorrida em períodos de grande perda de sólidos com o efluente final, em que a concentração máxima de N$\mathrm{NH}_{3}$ do efluente elevou-se até $22,7 \mathrm{mgN}-\mathrm{NH}_{3} / \mathrm{L}$ (2012) e 26,0 mgN-NH$/ \mathrm{L}$ (2013) e $10,1 \mathrm{mgN}-\mathrm{NH}_{3} / \mathrm{L}$ (2014) e 15,0 mgN-NH $3 / \mathrm{L}$ (2015).

\subsubsection{Nitrato}

$\mathrm{Na}$ Figura 77, apresenta-se os resultados da série temporal das determinações compostas do nitrogênio nitrato no esgoto à saída ao processo de lodos ativados. Esses resultados são apresentados em forma estatística na Tabela 47 e na Figura 78 em forma de gráficos de Box-Whiskers. 
Figura 77: Série temporal do Nitrato no efluente do processo de lodos ativados
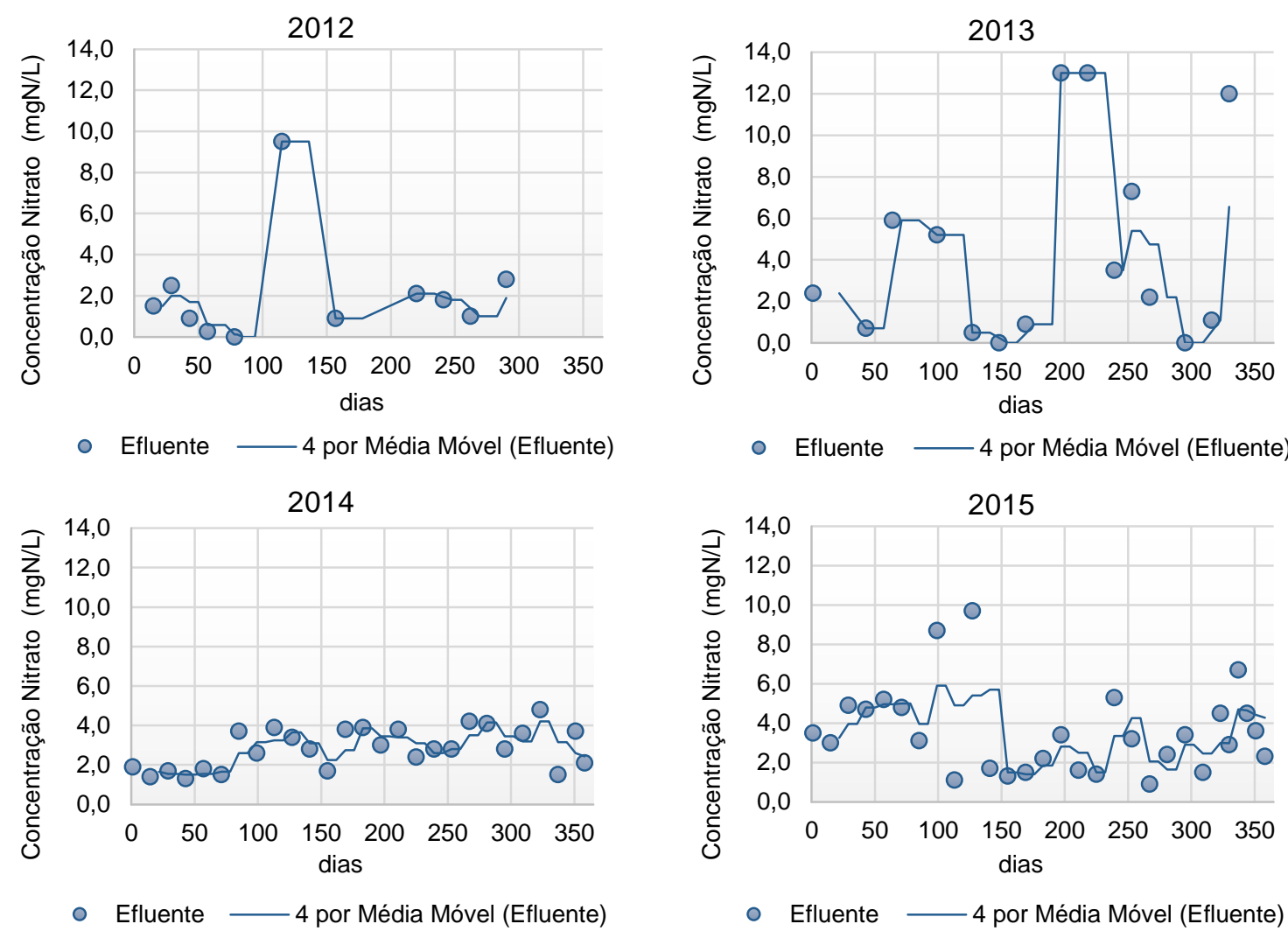

Tabela 47: $\mathrm{N}-\mathrm{NO}_{3}$ no efluente do processo de lodos ativados

\begin{tabular}{c|c|c|c|c}
\hline \multirow{2}{*}{ Variável } & \multicolumn{4}{|c}{ Análise composta } \\
\cline { 2 - 5 } & $\mathbf{2 0 1 2}$ & $\mathbf{2 0 1 3}$ & $\mathbf{2 0 1 4}$ & $\mathbf{2 0 1 5}$ \\
\hline média & 2,1 & 4,5 & 2,9 & 3,6 \\
\hline máximo & 9,5 & 13,0 & 4,8 & 9,7 \\
\hline mínimo & 0,0 & 0,0 & 1,3 & 0,9 \\
\hline DP & 2,6 & 4,8 & 1,0 & 2,2 \\
\hline CV (\%) & 120 & 105 & 36 & 61 \\
\hline $\mathbf{n}$ & 11 & 20 & 27 & 29 \\
\hline
\end{tabular}

* média das análises compostas 24 horas 
Figura 78: Diagramas Box-Whiskers de $\mathrm{N}^{-\mathrm{NO}_{3}}$ no efluente do processo de lodos ativados
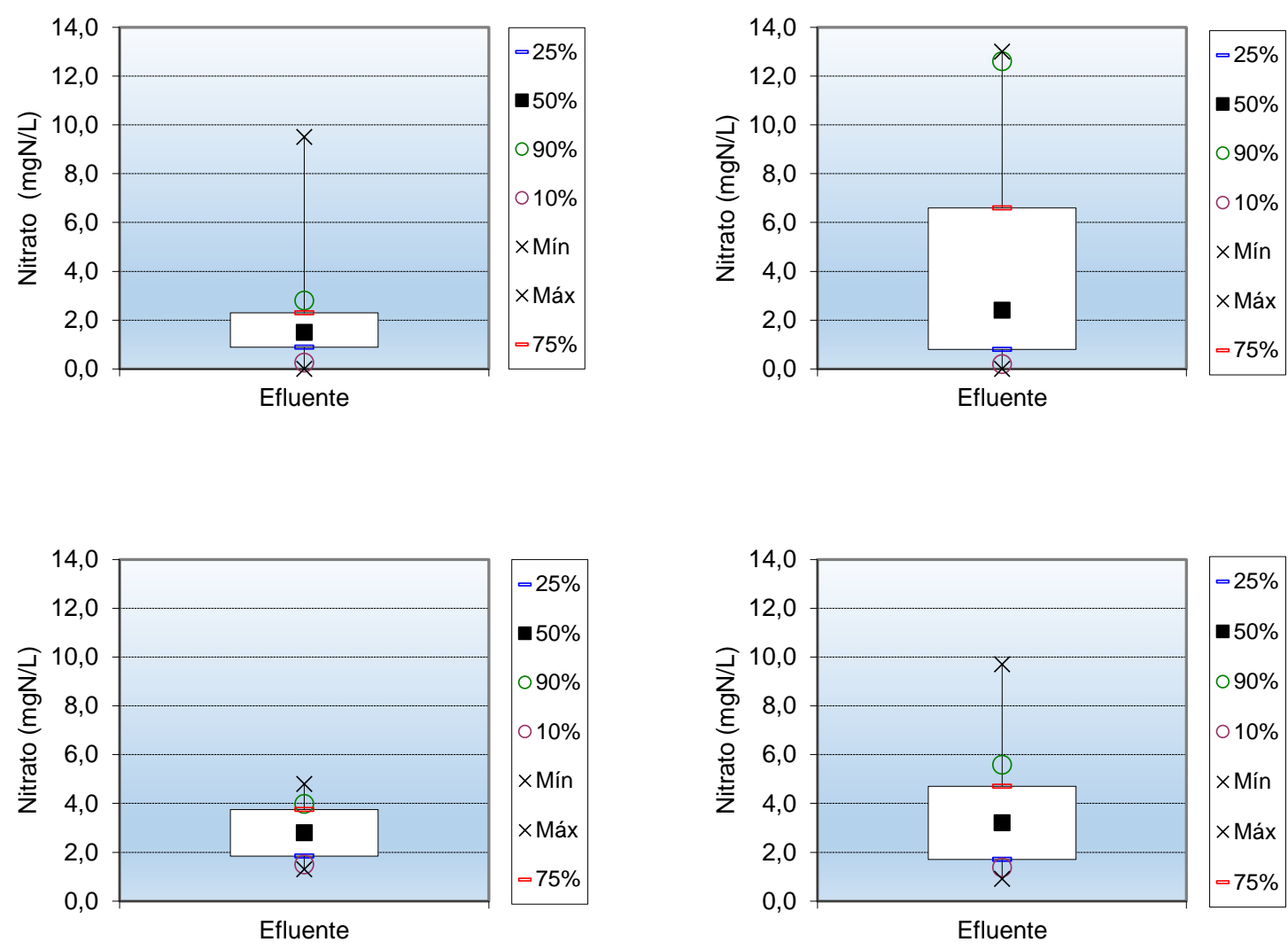

Observa-se que em praticamente todos os anos de estudo as concentrações de nitrato no efluente final foram menores que 10,0 $\mathrm{mgN}-\mathrm{NO}_{3} / \mathrm{L}$ (exceção de um pico de 13,0 $\mathrm{mg} / \mathrm{L}$ em 2013). Os resultados médios das concentrações da amostragem composta foram de 2,1, 4,5, 2,9 e 3,6 mgN-NO $/$ / L. Estes resultados denotam a expressiva eficiência do processo de desnitrificação, resultando em concentrações médias de $\mathrm{N}$ $\mathrm{NO}_{3}$ no efluente final sempre abaixo de $10,0 \mathrm{mgN}-\mathrm{NO}_{3} / \mathrm{L}$, que é o padrão para águas classe 2 estabelecidos na Resolução CONAMA 357/2005. Esses resultados são confirmados por meio do monitoramento online realizado no efluente final, onde foi instalado uma sonda de $\mathrm{N}^{-\mathrm{NO}_{3}}$ que permitiu avaliar o processo em tempo real. $\mathrm{Na}$ Figura 79 são apresentados os resultados da série temporal das determinações online da concentração do nitrogênio nitrato no efluente do processo de lodos ativados. Esses resultados são apresentados em forma estatística na Tabelas 48 e na Figura 80 em forma de gráficos de Box-Whiskers. 
Figura 79: Série temporal do monitoramento online de nitrato no efluente do processo de lodos ativados
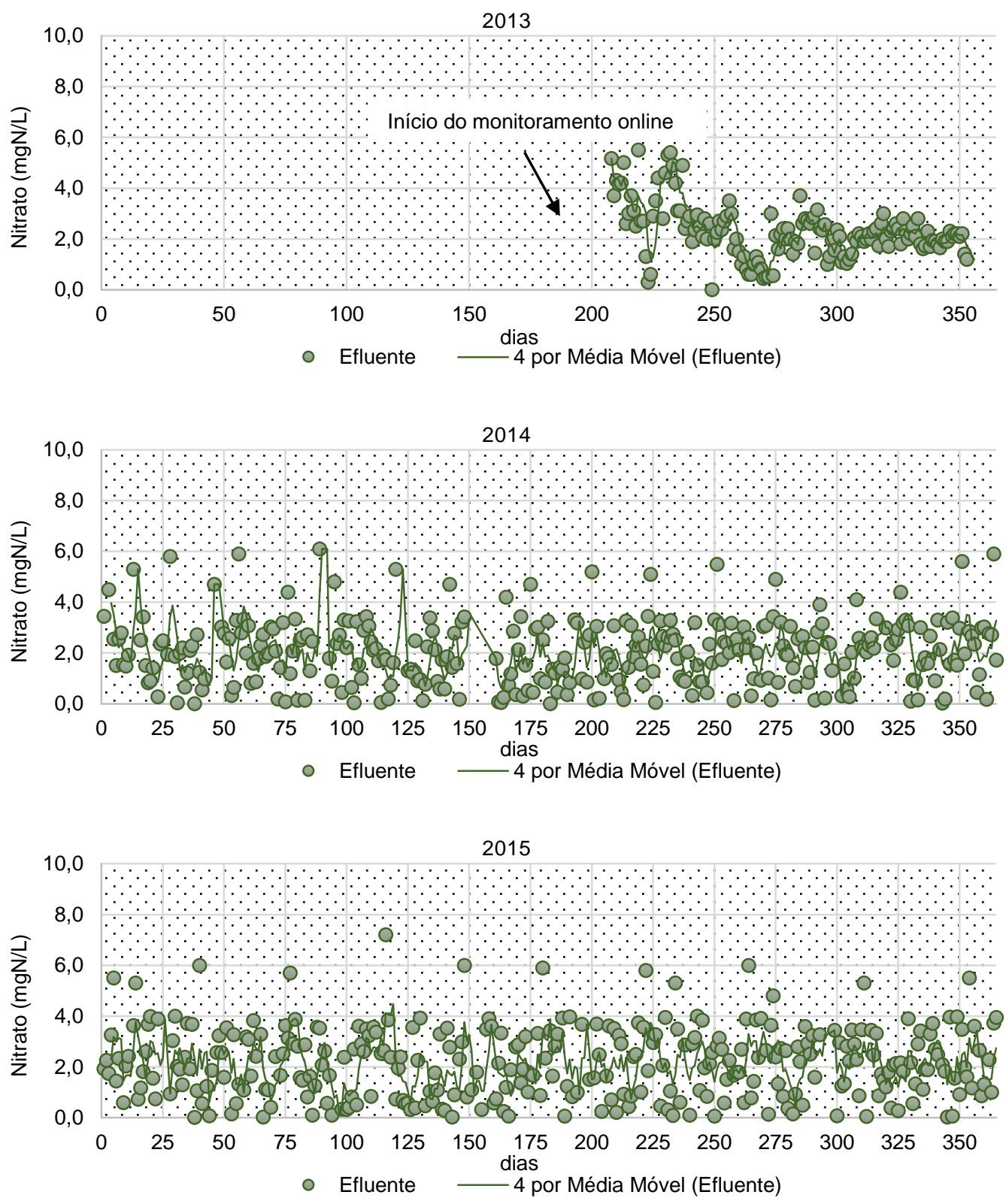

Tabela 48: $\mathrm{N}-\mathrm{NO}_{3}$ no efluente do processo de lodos ativados

\begin{tabular}{c|c|c|c}
\hline \multirow{2}{*}{ Variável } & \multicolumn{3}{|c}{ Monitoramento online } \\
\cline { 2 - 4 } & $\mathbf{2 0 1 3}$ & $\mathbf{2 0 1 4}$ & $\mathbf{2 0 1 5}$ \\
\hline média & 2,3 & 2,0 & 2,2 \\
\hline máximo & 6,2 & 6,1 & 7,2 \\
\hline mínimo & 0,3 & 0,0 & 0,0 \\
\hline DP & 1,1 & 1,3 & 1,4 \\
\hline CV (\%) & 50 & 60 & 60 \\
\hline $\mathbf{n}$ & 145 & 313 & 310 \\
\hline
\end{tabular}


Figura 80: Diagramas Box-Whiskers do monitoramento online de $\mathrm{N}-\mathrm{NO}_{3}$ no efluente do processo de lodos ativados

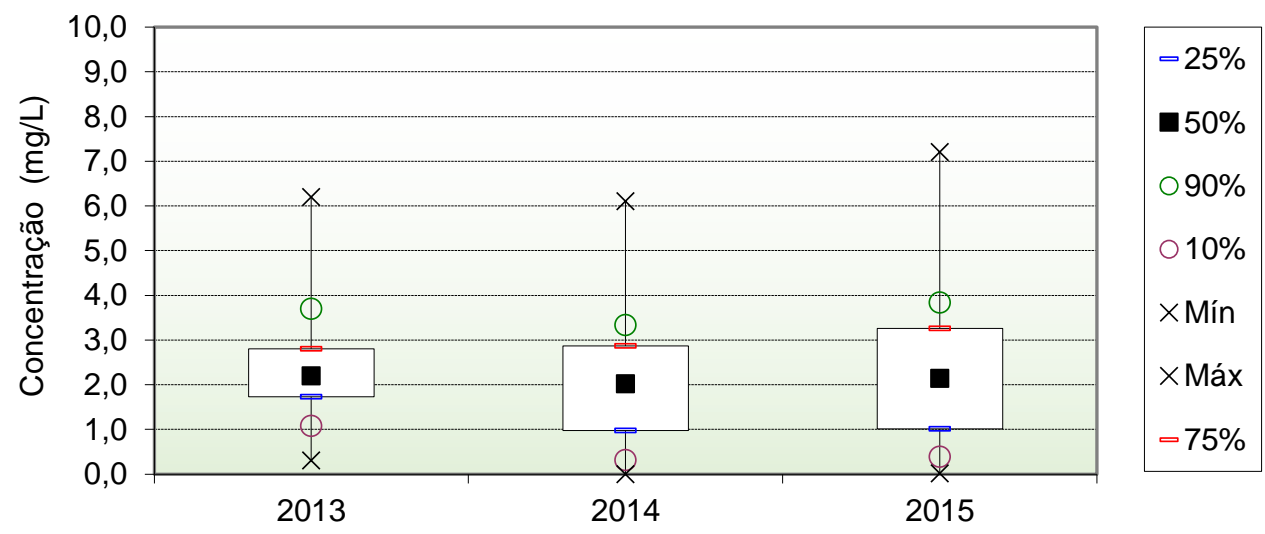

Observa-se na série histórica da Figura 79 a estabilidade do processo de desnitrificação, sendo que a concentração de nitrato se manteve abaixo de 6,0 mgN$\mathrm{NO}_{3} / \mathrm{L}$ praticamente em todo o período do estudo. No diagrama da Figura 80, observase uma mediana em torno de apenas $2,0 \mathrm{mgN}-\mathrm{NO}_{3} / \mathrm{L}$ no efluente final, providenciando uma segurança absoluta em relação ao controle deste importante contaminante químico formado durante a oxidação dos compostos nitrogenados presentes no esgoto. Assim, pode ser entendido que a etapa de desnitrificação não é limitante no processo de nitrificação e desnitrificação simultânea. Com base na teoria da formação de micro-zonas anóxicas no interior dos flocos, infere-se que efetivamente a penetração do íon nitrato para as camadas mais internas dos flocos ocorre a contento, enquanto que o mesmo não acontece com as moléculas de oxigênio dissolvido, de forma que não ocorre a concorrência entre os dois aceptores de elétrons.

\subsubsection{Resultados do balanço de massa do material nitrogenado}

Nesse item apresenta-se o balanço de massa do material nitrogenado obtido durante os anos 2012, 2013, 2014 e 2015. As determinações seguiram o modelo descrito em van Haandel e Marais, 1999 e o detalhamento de cada termo está descrito na lista de símbolos.

Exemplificando-se, para o ano de 2015, tem-se os seguintes valores: 
$\mathrm{f}_{\mathrm{n}}=$ adotado 0,$1 ; \mathrm{R}_{\mathrm{S}}=12$ dias; $\mathrm{Vr}=27.570 .000 \mathrm{~L}^{-1} ; \mathrm{N}_{\mathrm{oa}}=13,0 \mathrm{mgN}$-org. $\mathrm{L}^{-1} ; \mathrm{N}_{\mathrm{oe}}=1,25 \mathrm{mgN}-$

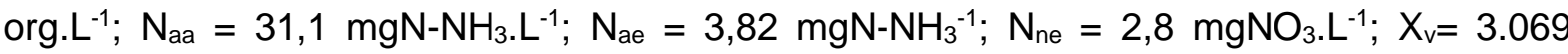

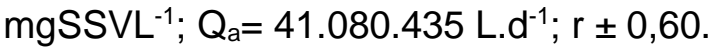

Portanto calcula-se:

Fluxo de material nitrogenado no lodo de excesso $\left(\mathrm{MN}_{\mathrm{I}}\right)$ :

$\mathrm{MN}_{\mathrm{l}}=\mathrm{f}_{\mathrm{n}}{ }^{*} \mathrm{~V}_{\mathrm{r}}{ }^{*} \mathrm{X}_{\mathrm{v}} / \mathrm{R}_{\mathrm{s}}=0,1{ }^{*} 27570000 * 3069 / 12=705.102 .750$

Fluxo de material nitrogenado afluente $\left(\mathrm{MN}_{\mathrm{ta}}\right)$ :

$\mathrm{MN}_{\mathrm{ta}}=\mathrm{Q}_{\mathrm{a}}{ }^{*}\left(\mathrm{~N}_{\mathrm{oa}}+\mathrm{N}_{\mathrm{aa}}+\mathrm{N}_{\mathrm{na}}\right)=\mathrm{Q}_{\mathrm{a}}{ }^{*} \mathrm{~N}_{\mathrm{ta}}=41080435^{*} 44,1=1.809 .645 .108$

Fluxo de material nitrogenado efluente $\left(\mathrm{MN}_{\mathrm{te}}\right)$ :

$M N_{\text {te }}=Q_{a}{ }^{*}\left(N_{o e}+N_{a e}+N_{n e}\right)=Q_{a}^{*} N_{\text {te }}=41080435^{\star} 7,9=323.368 .365$

Fluxo de material nitrogenado desnitrificado no sistema de lodo ativado $\left(\mathrm{MN}_{\mathrm{d}}\right)$ : $M N_{d}=\left(Q_{a}{ }^{*}\right)^{*} \Delta N_{n}=\left(41080435^{*} 0,6\right)^{*}(13,0+31,1-3,8-2,8)=924 \cdot 309.787$

Por fim, o balanço de massa do material nitrogenado para o sistema de lodo ativado $\left(B_{n}\right)$, pode ser determinado como se segue:

$B_{n}=\left(M_{1}+M_{\text {te }}+M_{d}\right) / M_{t a}=(705.102 .750+323.368 .365+924.309 .787) / 1.809 .645 .108$

$B_{n}=1,08$

Portanto, em relação aos resultados do ano de 2015, o balanço de massa do material nitrogenado foi consistente, com $B_{\circ}=1,08$, ou seja, com desvio de apenas $8 \%$. Na Tabela 49 apresenta-se os resultados do balanço de massa para o período de estudo. 
Tabela 49: Balanço de massa do material nitrogenado no sistema de lodo ativado

\begin{tabular}{c|c|c|c|c}
\hline Variável & $\mathbf{2 0 1 2}$ & $\mathbf{2 0 1 3}$ & $\mathbf{2 0 1 4}$ & $\mathbf{2 0 1 5}$ \\
\hline Média & 1,73 & 1,15 & 1,09 & 1,08 \\
\hline máximo & 3,13 & 1,34 & 1,54 & 1,43 \\
\hline mínimo & 1,47 & 1,03 & 0,89 & 0,87 \\
\hline DP & 0,16 & 0,04 & 0,06 & 0,05 \\
\hline CV (\%) & 0,09 & 0,04 & 0,05 & 0,05 \\
\hline AT & 1,66 & 0,31 & 0,65 & 0,56 \\
\hline $\mathrm{n}$ & 305 & 304 & 320 & 330 \\
\hline
\end{tabular}

Os resultados mostram que o balanço de material nitrogenado nos anos de $2012 \mathrm{e}$ 2013, não tiveram boa aproximação ao valor teórico $B_{n}=1,0$, estando em 2012 mais que $73 \%$ distante desse resultado. Esse desvio deve-se pelo fato do ano de 2012 o processo ter sido operado com limitações no controle operacional e problemas com percas excessivas de sólidos com o efluente final. No ano de 2013, com um controle operacional mais rigoroso e com a instalação dos controladores/medidores, resultou em um balanço entorno de 15\% de desvio do teórico e nos anos de 2014 e 2105 os valores médios tiveram boa aproximação ao valor teórico $B_{n}=1,0$, estando menos que $10 \%$ distante desse resultado. Conclui-se que, em boa aproximação, nestes últimos anos o balanço de massa do material nitrogenado demonstrou-se consistente. Isto significa que os dados experimentais são confiáveis e o sistema de lodo ativado foi operado sob condições estacionárias. 


\subsubsection{Monitoramento do óxido nitroso no processo de lodos ativados}

$\mathrm{Na}$ Tabela 50 apresenta-se os resultados médios obtidos durante o monitoramento online de $\mathrm{N}_{2} \mathrm{O}$.

Tabela 50: Monitoramento da emissão de $\mathrm{N}_{2} \mathrm{O}$ no tanque de aeração

\begin{tabular}{c|c|c}
\hline \multicolumn{3}{c}{$\mathbf{N}_{\mathbf{2}} \mathbf{O}\left(\mathbf{g N}-\mathbf{N}_{2} \mathbf{O}^{-} \mathbf{h}^{-1}\right)$} \\
\hline Variável & Ensaio I & Ensaio II \\
\hline Média & 1,3 & 3,6 \\
\hline Máximo & 6,1 & 15,0 \\
\hline Mínimo & $-1,3$ & 0,9 \\
\hline DP & 3,3 & 6,1 \\
\hline Monitoramento (horas) & 24 & 24 \\
\hline $\mathrm{N}$ & 85.630 & 85.630
\end{tabular}

A taxa média de emissão de $\mathrm{N}_{2} \mathrm{O}$ no Ensaio I foi de $1,3 \mathrm{gN}-\mathrm{N}_{2} \mathrm{O} / \mathrm{h}^{-1}$ e no Ensaio II foi de 3,6 $\mathrm{gN}-\mathrm{N}_{2} \mathrm{O} / \mathrm{h}^{-1}$. Observa-se no Ensaio I que houve episódios de consumo de $\mathrm{N}_{2} \mathrm{O}$ chegando a valores de $-1,3 \mathrm{gN}-\mathrm{N}_{2} \mathrm{O} / \mathrm{h}^{-1}$. Com base nos resultados obtidos e as determinações analíticas realizados durante os ensaios, foi possível realizar o balanço de massa do material nitrogenado no processo de lodos ativados. Foram desprezadas as concentrações de nitrito e nitrato afluente, por resultarem valores menores que 0,1 $\mathrm{mgN}-\mathrm{NO}_{3} / \mathrm{L}$. Assim tem-se:

Dados das determinações analíticas:

Valores médios do Ensaio I, primeiras 24 horas:

$\mathrm{N}_{\text {oa }}=19,0 \mathrm{mgN}$-org. $\mathrm{L}^{-1} ; \mathrm{N}_{\mathrm{oe}}=4,0 \mathrm{mgN}$-org. $\mathrm{L}^{-1} ; \mathrm{N}_{\mathrm{aa}}=42 \mathrm{mgN}-\mathrm{NH}_{3} \cdot \mathrm{L}^{-1} ; \mathrm{N}_{\mathrm{ae}}=4,0 \mathrm{mgN}-\mathrm{NH}_{3}{ }^{-1} ;$ $\mathrm{N}_{\text {ne }}=2,0 \mathrm{mgNO}_{3} \cdot \mathrm{L}^{-1} ; \mathrm{N}_{\text {lodo }}=9,5 \mathrm{mgN}_{\text {total }} \cdot \mathrm{L}^{-1} ; \mathrm{Q}_{\mathrm{a}}=1.696 \mathrm{~m}^{3} \cdot \mathrm{h}^{-1} ;$

Carga de $\mathrm{N}_{\text {afluente }}=(19,0+42,0) / 1000 \times 1.696=104 \mathrm{kgN}_{\text {total }} \cdot \mathrm{h}^{-1}$;

Carga de $\mathrm{N}_{\text {efluente }}=(4,0+4,0+2,0) / 1000 \times 1.696=17 \mathrm{kgN}_{\text {total }} \cdot \mathrm{h}^{-1}$;

Carga de $\mathrm{N}_{\text {removida }}=104-17=87 \mathrm{kgN}_{\text {total }} \cdot \mathrm{h}^{-1}$;

Carga de $\mathrm{N}_{\text {lodo excedente }}=9,5 / 1000 \times 1.710=16 \mathrm{kgN}_{\text {total }} \cdot \mathrm{h}^{-1}$; 
Carga de $\mathrm{N}_{\text {via N2O }}=1,3 / 1000=0,0013 \mathrm{kgN}_{2} \mathrm{O} \cdot \mathrm{h}^{-1}$;

Carga de $\mathrm{N}_{\text {via N2 }}=104-17-16-0,0013=71 \mathrm{kgN}_{2} \cdot \mathrm{h}^{-1}$.

Com os dados do balanço de massa do material nitrogenado no ensaio construímos a Figura 81.

Figura 81: Balanço de massa do material nitrogenado ensaio I

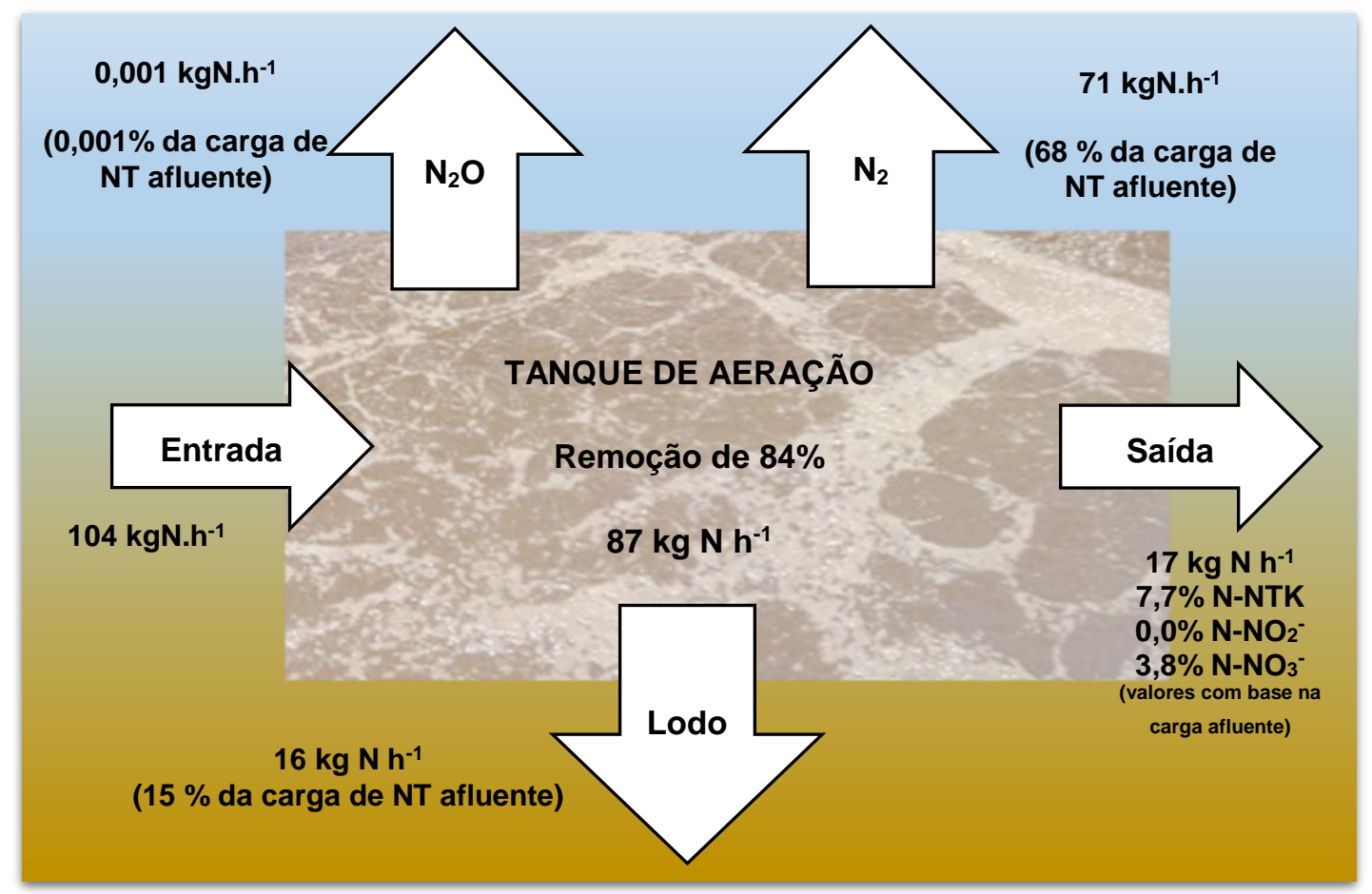

Valores médios do Ensaio II, 24 horas:

$\mathrm{N}_{\mathrm{oa}}=13,0 \mathrm{mgN}$-org. $\mathrm{L}^{-1} ; \mathrm{N}_{\mathrm{oe}}=1,5 \mathrm{mgN}$-org. $\mathrm{L}^{-1} ; \mathrm{N}_{\mathrm{aa}}=32,0 \mathrm{mgN}-\mathrm{NH}_{3} \cdot \mathrm{L}^{-1} ; \mathrm{N}_{\mathrm{ae}}=2,0 \mathrm{mgN}-\mathrm{NH}_{3}{ }^{-1} ;$ $\mathrm{N}_{\mathrm{ne}}=1,3 \mathrm{mgNO}_{3} \cdot \mathrm{L}^{-1} ; \mathrm{N}_{\text {lodo }}=11,3 \mathrm{mgN}_{\text {total }} \cdot \mathrm{L}^{-1} ; \mathrm{Q}_{\mathrm{a}}=1.710 \mathrm{~m}^{3} \cdot \mathrm{h}^{-1}$;

Carga de $\mathrm{N}_{\text {afluente }}=(13,0+32,0) / 1000 \times 1.710=77,0 \mathrm{kgN} \mathrm{N}_{\text {total }} \cdot \mathrm{h}^{-1}$;

Carga de $\mathrm{N}_{\text {efluente }}=(2,0+1,5+2,0) / 1000 \times 1.710=5,5 \mathrm{kgN}_{\text {total. }} \cdot \mathrm{h}^{-1}$;

Carga de $\mathrm{N}_{\text {removida }}=77,0-5,5=71,5 \mathrm{kgN}_{\text {total. }} \cdot \mathrm{h}^{-1}$;

Carga de $\mathrm{N}_{\text {lodo excedente }}=11,3 / 1000 \times 1.710=19,3 \mathrm{kgN}_{\text {total }} \cdot \mathrm{h}^{-1}$;

Carga de $\mathrm{N}_{\text {via N2O }}=3,6 / 1000=0,004 \mathrm{kgN}_{2} \mathrm{O} \cdot \mathrm{h}^{-1}$;

Carga de $\mathrm{N}_{\text {via N2 }}=77,0-5,5-19,3-0,004=52,2 \mathrm{kgN}_{\text {total }} \cdot \mathrm{h}^{-1}$; 
Com os dados do balanço de massa do material nitrogenado no ensaio construímos a Figura 82.

Figura 82: Balanço de massa do material nitrogenado ensaio II

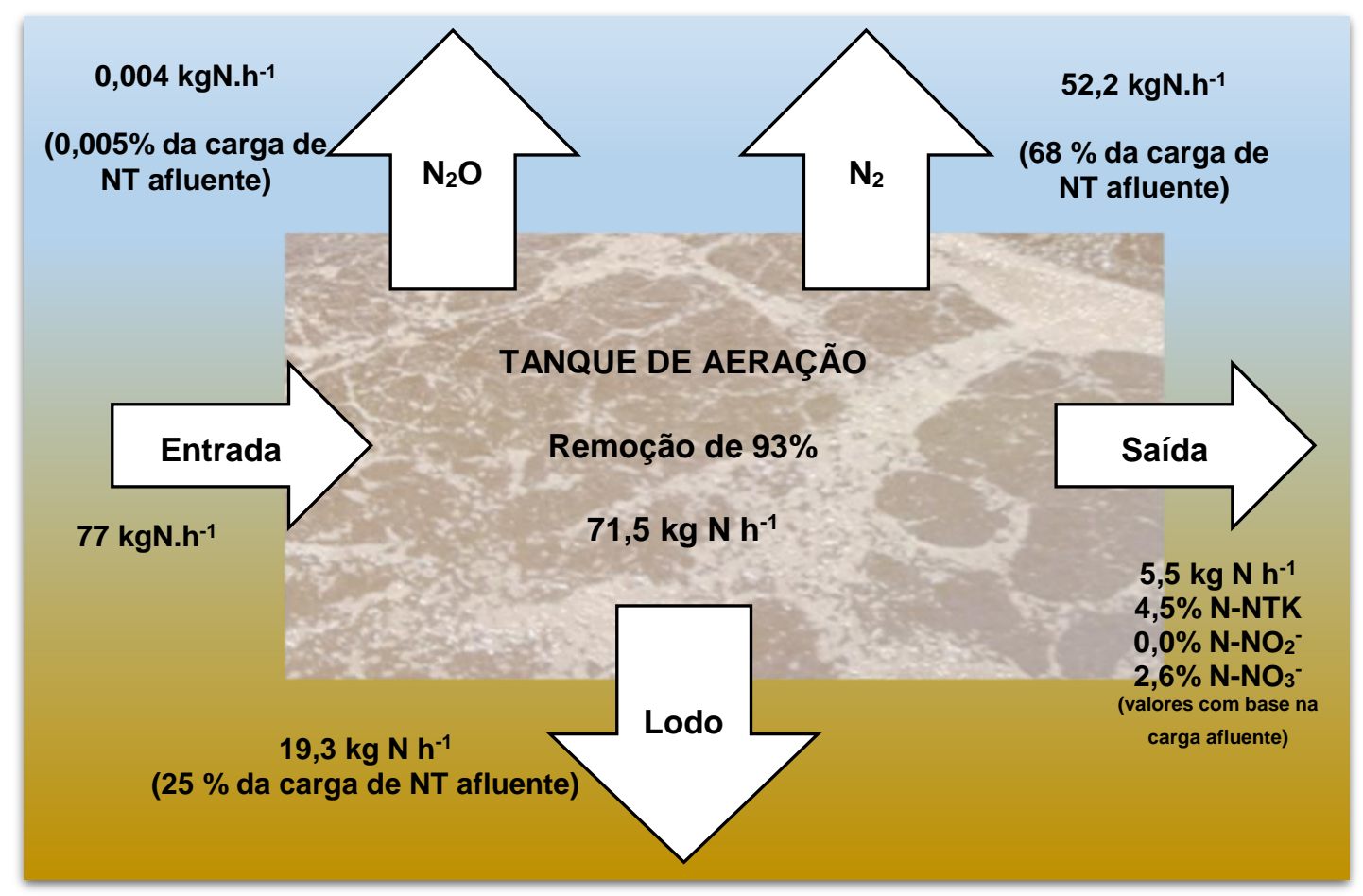

A remoção do material nitrogenado no processo de NDS desenvolvido na ETE Limoeiro foi em sua maior parte via nitrogênio molecular cerca de $68 \%$ e via lodo de excesso em média 15 a $25 \%$ (valores próximos a literatura), a emissão de óxido nitroso no processo pode ser desprezada pois resultou em valores menores que $0,005 \%$ da carga nitrogenada aplicada. Isto significa, que a remoção dos compostos nitrogenados via NDS na ETE Limoeiro não contribuí para os gases de efeito estufa.

\subsubsection{Variação da alcalinidade devido a amonificação, nitrificação e desnitrificação no processo de lodo ativado}

Nas Tabelas 51 e 52 apresenta-se os resultados da estatística descritiva básica aplicada aos dados de alcalinidade total no esgoto afluente e efluente do processo de lodos ativados. Estes resultados são lançados em gráfico nas Figura 83 (séries históricas) e Figura 84 (diagramas Box-Whiskers). 
Tabela 51: Valores médios de alcalinidade no esgoto afluente e efluente e a variação obtida experimentalmente devido à amonificação, nitrificação e desnitrificação (20122013).

\section{Alcalinidade total Afluente e Efluente - $\left(\mathrm{mgCaCO}_{3} \cdot \mathrm{L}^{-1}\right)$}

\begin{tabular}{cc|c|c|c|c|c}
\hline \multirow{2}{*}{ Variável } & \multicolumn{3}{c}{2012} & \multicolumn{5}{c}{$\mathbf{2 0 1 3}$} \\
\cline { 2 - 7 } & Afluente & Efluente & $\Delta$ alc $\mathbf{c}_{\mathbf{t}}$ & Afluente & Efluente & $\Delta \mathbf{a l c}_{\mathbf{t}}$ \\
\hline média & 217 & 35 & -183 & 206 & 127 & -79 \\
\hline máximo & 275 & 75 & -115 & 280 & 200 & -2 \\
\hline mínimo & 185 & 15 & -225 & 140 & 90 & -140 \\
\hline DP & 23 & 20 & 35 & 27,1 & 28,6 & 31 \\
\hline CV (\%) & 10,0 & 57,0 & 20,0 & 13 & 23 & 39,0 \\
\hline $\mathrm{N}$ & \multicolumn{3}{|c|}{19} & \multicolumn{3}{|c}{29} \\
\hline
\end{tabular}

Onde: $\Delta$ alct: Variação da alcalinidade devido à amonificação, nitrificação e desnitrificação.

Tabela 52: Valores médios de alcalinidade no esgoto afluente e efluente e a variação obtida experimentalmente devido à amonificação, nitrificação e desnitrificação (20142015).

Alcalinidade total Afluente e Efluente - $\left(\mathrm{mgCaCO}_{3} \cdot \mathrm{L}^{-1}\right)$

\begin{tabular}{c|c|c|c|c|c|c}
\hline \multicolumn{7}{|c}{$\mathbf{2 0 1 4}$} \\
\hline Variável & Afluente & Efluente & $\Delta \mathbf{a l c} \mathbf{t}$ & Afluente & Efluente & $\Delta \mathbf{a l c}_{\mathbf{t}}$ \\
\hline média & 217 & 121 & -95 & 229 & 126 & -101 \\
\hline máximo & 250 & 156 & -30 & 324 & 240 & -20 \\
\hline mínimo & 154 & 92 & -132 & 170 & 92 & -142 \\
\hline DP & 19,5 & 11,6 & 19 & 28,9 & 27,1 & 27 \\
\hline CV (\%) & 9,0 & 10,0 & 20,0 & 13,0 & 22,0 & 30,0 \\
\hline $\mathrm{N}$ & \multicolumn{7}{|c|}{34} & \multicolumn{4}{|c}{47} \\
\hline
\end{tabular}

Onde: $\Delta$ alct: Variação da alcalinidade devido à amonificação, nitrificação e desnitrificação. 
Figura 83: Série temporal da Alcalinidade no esgoto afluente e efluente do processo de lodos ativados
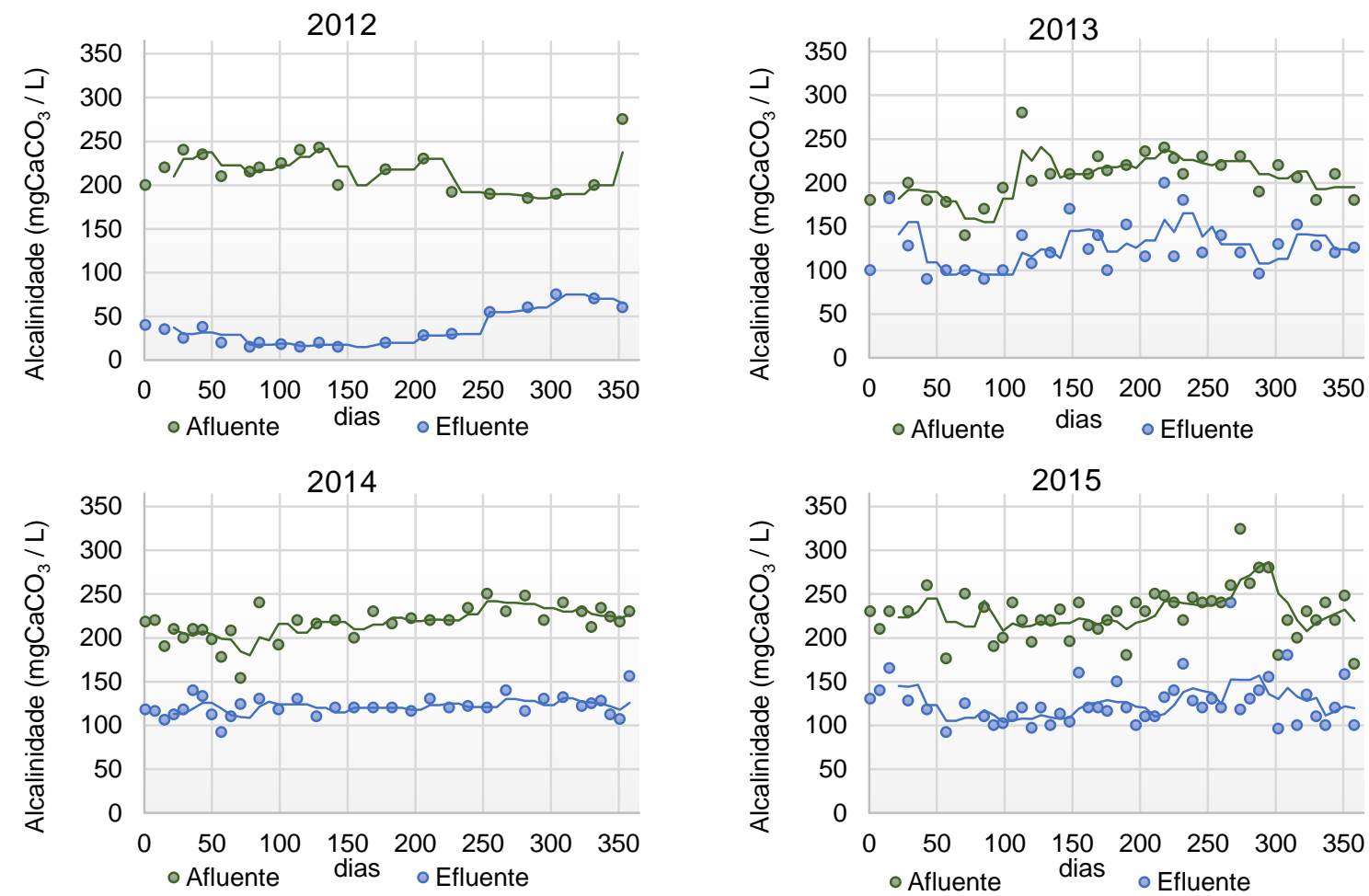

Figura 84: Diagramas Box-Whiskers da Alcalinidade do esgoto afluente e efluente do processo de lodos ativados
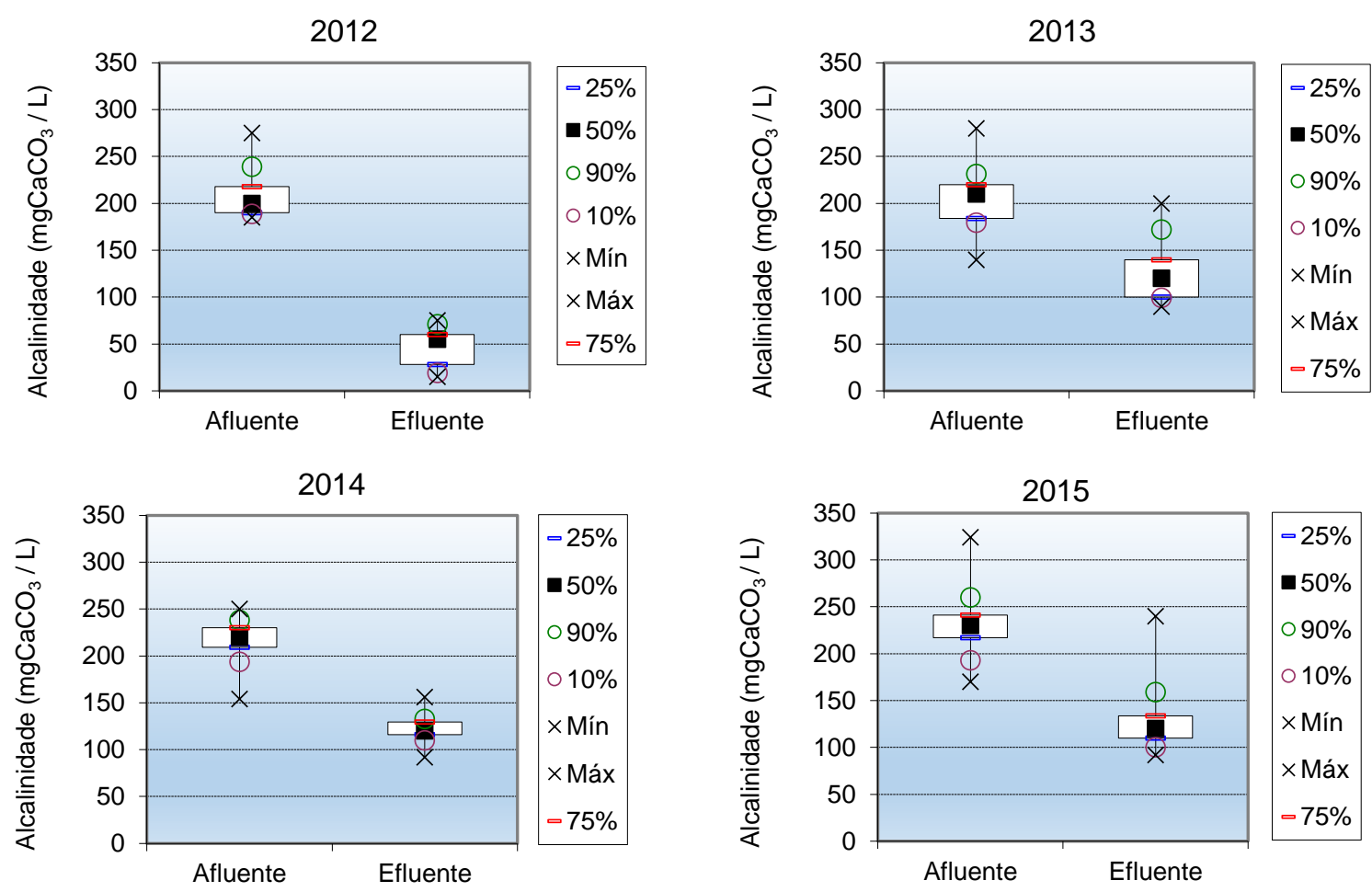
Os resultados médios da concentração de alcalinidade no esgoto à entrada e à saída do processo de lodos ativados foram de 217, 206, 217 e $229 \mathrm{mgCaCO}_{3} / \mathrm{L}$ e no efluente de 35, 127, 121 e $126 \mathrm{mgCaCO}_{3} / \mathrm{L}$ nos anos de 2012, 2013, 2014 e 2015, respectivamente. Com base nesses resultados e adotando-se a nomenclatura apresentada por van Haandel e Marais e fazendo-se um balanço de massa das formas nitrogenadas, as Tabelas 53 e 54 apresentam os valores de nitrogênio nitrificado e o consumo correspondente de alcalinidade.

Tabela 53: Variação da alcalinidade teórica causada pelo efeito estequiométrico devido à amonificação, nitrificação e desnitrificação (2012-2013).

\begin{tabular}{|c|c|c|c|c|c|c|c|c|}
\hline \multicolumn{9}{|c|}{ Variação da alcalinidade no sistema de lodo ativado $\left(\mathrm{mgCaCO}_{3} \cdot \mathrm{L}^{-1}\right)$} \\
\hline \multirow{2}{*}{ Variável } & \multicolumn{4}{|c|}{2012} & \multicolumn{4}{|c|}{2013} \\
\hline & $\Delta \mathbf{a l C}_{\mathrm{am}}$ & $\Delta \mathbf{a l C}_{\mathbf{n}}$ & $\Delta \mathbf{a l c}_{\mathrm{d}}$ & $\Delta \mathbf{a l c}_{\mathrm{t}}$ & $\Delta \mathbf{a l C}_{\mathrm{am}}$ & $\Delta \mathbf{a l} \mathbf{c}_{\mathbf{n}}$ & $\Delta \mathbf{a l C}_{\mathrm{d}}$ & $\Delta \mathbf{a l c}_{\mathrm{t}}$ \\
\hline média & -32 & -107 & 46 & -92 & -22 & -185 & 78 & -128 \\
\hline máximo & 12 & 36 & 104 & -50 & -5 & -37 & 175 & -43 \\
\hline mínimo & -75 & -215 & -25 & -143 & -49 & -366 & -10 & -222 \\
\hline $\mathrm{DP}$ & 26 & 79 & 40 & 24 & 12 & 100 & 58 & 45 \\
\hline CV (\%) & $-0,8$ & $-0,7$ & 0,9 & $-0,3$ & $-0,5$ & $-0,6$ & 0,7 & $-0,4$ \\
\hline $\mathrm{N}$ & \multicolumn{4}{|c|}{17} & \multicolumn{4}{|c|}{18} \\
\hline Recuperação & \multicolumn{4}{|c|}{ * } & \multicolumn{4}{|c|}{$69 \%$} \\
\hline
\end{tabular}

Onde: $\Delta \mathbf{a l} \mathbf{c}_{\mathbf{a m}}$ : Variação da alcalinidade devido à amonificação; $\Delta \mathbf{a l} \mathbf{c}_{\mathbf{n}}$ : Variação da alcalinidade devido à nitrificação; $\Delta \mathbf{a l c}_{\mathbf{d}}$ : Variação da alcalinidade devido à desnitrificação; $\Delta \mathbf{a l c}_{\mathbf{t}}$ : Variação da alcalinidade devido à amonificação, nitrificação e desnitrificação. 
Tabela 54: Variação da alcalinidade teórica causada pelo efeito estequiométrico devido à amonificação, nitrificação e desnitrificação (2014-2015)

\begin{tabular}{|c|c|c|c|c|c|c|c|c|}
\hline \multicolumn{9}{|c|}{ Variação da alcalinidade no sistema de lodo ativado $\left(\mathrm{mgCaCO}_{3 .} \mathrm{L}^{-1}\right)$} \\
\hline \multirow{2}{*}{ Variável } & \multicolumn{4}{|c|}{2014} & \multicolumn{4}{|c|}{2015} \\
\hline & $\Delta$ alCam & $\Delta \mathbf{a l C}_{\mathbf{n}}$ & $\Delta \mathbf{a l c}_{\mathrm{d}}$ & $\Delta \mathrm{alc}_{\mathrm{t}}$ & $\Delta \mathrm{alCam}$ & $\Delta \mathbf{a l c} \mathbf{c}_{\mathbf{n}}$ & $\Delta \mathbf{a l c}_{\mathrm{d}}$ & $\Delta \mathbf{a l c} \mathbf{c}_{\mathbf{t}}$ \\
\hline média & -9 & -199 & 90 & -119 & 3 & -200 & 25 & -107 \\
\hline máximo & 12 & -63 & 146 & -34 & 35 & -103 & 51 & -56 \\
\hline mínimo & -27 & -318 & 18 & -195 & -19 & -371 & 10 & -193 \\
\hline DP & 10 & 59 & 30 & 35 & 12 & 62 & 9 & 37 \\
\hline CV (\%) & $-1,0$ & $-0,3$ & 0,3 & $-0,3$ & 4,7 & $-0,3$ & 0,4 & $-0,3$ \\
\hline $\mathrm{N}$ & \multicolumn{4}{|c|}{31} & \multicolumn{4}{|c|}{28} \\
\hline Recuperação & \multicolumn{4}{|c|}{$80 \%$} & \multicolumn{4}{|c|}{$94 \%$} \\
\hline
\end{tabular}

Onde: $\Delta \mathbf{a l} \mathbf{c}_{\mathbf{a m}}$ : Variação da alcalinidade devido à amonificação; $\Delta \mathbf{a} \mathbf{l}_{\mathbf{n}}$ : Variação da alcalinidade devido à nitrificação; $\Delta \mathbf{a l} \mathbf{c}_{\mathbf{d}}$ : Variação da alcalinidade devido à desnitrificação; $\Delta \mathbf{a} \mathbf{l}_{\mathbf{t}}$ : Variação da alcalinidade devido à amonificação, nitrificação e desnitrificação.

O resultado do balanço de alcalinidade é sintetizado na Figura 85:

Figura 85: Resultado do balanço de alcalinidade no processo de lodos ativados

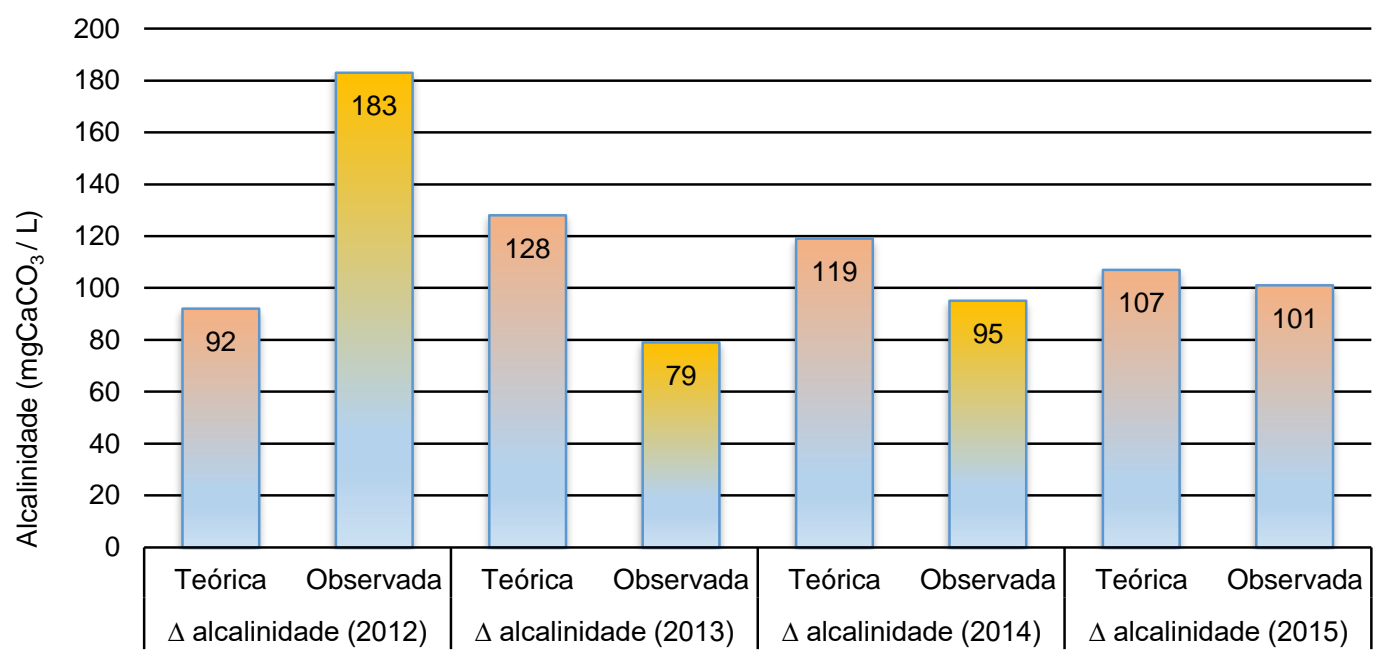


De acordo com a estequiometria do processo, para cada mg de nitrogênio nitrificado, são consumidas $7,14 \mathrm{mg}$ de alcalinidade e para cada $\mathrm{mg}$ de $\mathrm{N}$-Nitrato desnitrificado ocorre a reposição de $3,57 \mathrm{mg}$ de alcalinidade.

Exemplificando para o ano de 2015, temos:

Nitrogênio amonificado:

$\mathrm{Nam}=\mathrm{Noa}_{\mathrm{oa}}-\left(\mathrm{N}_{\mathrm{oe}}+\mathrm{N}_{\mathrm{l}}\right)$

$\Delta$ alcam $=3,57 \Delta \mathrm{N}_{\mathrm{am}}=3,57\left(\mathrm{~N}_{\mathrm{oa}}-\mathrm{N}_{\mathrm{oe}}-\mathrm{N}_{\mathrm{l}}\right)$

Resultados das determinações analíticas do período de 2015:

\begin{tabular}{c|c|c|c|c|c|c|c|c}
\hline $\mathbf{N T K}_{\mathbf{a}}$ & $\mathbf{N T K}_{\mathbf{e}}$ & $\mathbf{N H}_{\mathbf{3 a}}$ & $\mathbf{N H}_{\mathbf{3 e}}$ & $\mathbf{N}_{\mathbf{o a}}$ & $\mathbf{N}_{\mathbf{o e}}$ & $\mathbf{N}_{\mathbf{l}}$ & $\mathbf{N}_{\mathbf{a m}}$ & $\Delta_{\text {alcam }}$ \\
\hline 44 & 5 & 31 & 4 & 13 & 1 & 11 & 1 & 3 \\
\hline
\end{tabular}

$N_{c}=N_{k a}-N_{k e}-N_{l}$

$\Delta$ alc $\mathrm{c}_{\mathrm{n}}=-7,14 \mathrm{~N}_{\mathrm{c}}=-7,14\left(\mathrm{~N}_{\mathrm{ka}}-\mathrm{N}_{\mathrm{ke}}-\mathrm{N}_{\mathrm{l}}\right)$

$\Delta \mathrm{N}_{\mathrm{d}}=\mathrm{N}_{\mathrm{na}}+\mathrm{N}_{\mathrm{c}}-\mathrm{N}_{\mathrm{ne}}$

$\Delta$ alcd $=3,57 \Delta \mathrm{N}_{d}=3,57\left(\mathrm{~N}_{\mathrm{na}}+\mathrm{N}_{\mathrm{ka}}-\mathrm{N}_{\mathrm{ke}}-\mathrm{N}_{\mathrm{l}}-\mathrm{N}_{\mathrm{ne}}\right)$

$\Delta$ alct $_{t}=\Delta$ alcam $+\Delta$ alc ${ }_{n}+\Delta$ alc $c_{d}=3,57\left(N_{o a}-N_{o e}-N_{I}\right)-7,14\left(N_{k a}-N_{k e}-N_{I}\right)+3,57\left(N_{n a}+N_{k a}-N_{k e}-N_{l}-\right.$ $\mathrm{N} n$ )

$\Delta$ alct $_{t}=-3,57\left(\mathrm{~N}_{\mathrm{aa}}-\mathrm{N}_{\mathrm{na}}-\mathrm{N}_{\mathrm{ae}}+\mathrm{N}_{\mathrm{ne}}\right)=3,57\left(\Delta \mathrm{N}_{\mathrm{a}}-\Delta \mathrm{N}_{\mathrm{n}}\right)$

Resultado do balanço:

\begin{tabular}{l|c|c|c|c|c|c|c|c|c|c}
\hline Nc & $\Delta$ alcn & Nna & Nne & $\Delta$ Nd & $\Delta$ alcd & $\Delta$ alc. teórica & Alc af & Alc ef & $\Delta$ alc. observada & $(\mathbf{R} \%)$ \\
\hline 28 & -200 & 0 & 3 & 25 & 90 & -107 & 229 & 126 & -101 & 94 \\
\hline
\end{tabular}

Portanto, de acordo com os resultados da série nitrogenada, deveria ter ocorrido um consumo líquido de alcalinidade de $107 \mathrm{mgCaCO}_{3} / \mathrm{L}$, enquanto que os resultados de alcalinidade indicaram o consumo líquido de $101 \mathrm{mgCaCO}_{3} / \mathrm{L}$, ocorrendo, portanto 94\% de recuperação. Desse modo, conclui-se que o balanço de alcalinidade no processo de lodos ativados, com exceção do ano de 2012, torna-se compatível com a ocorrência simultânea do processo de amonificação, nitrificação e desnitrificação. 


\subsection{Testes Respirométricos}

\subsubsection{Resultados das frações de matéria orgânica no esgoto sanitário afluente}

A seguir serão apresentados os resultados dos ensaios de respirometria que embasaram a obtenção de coeficientes cinéticos relativos à remoção de matéria orgânica e nitrogênio em condições de nitrificação e desnitrificação simultâneas. Na Tabela 55 apresenta-se os resultados das frações de matéria orgânica no esgoto sanitário afluente ao processo de lodo ativado, para a obtenção dos coeficientes cinéticos.

Tabela 55: Frações de matéria orgânica presente no esgoto sanitário

\begin{tabular}{c|c|c|c|c|c|c}
\hline $\begin{array}{c}\text { Valores } \\
\text { médios }\end{array}$ & $\begin{array}{c}\text { Sta } \\
(\mathbf{m g} / \mathbf{L})\end{array}$ & $\begin{array}{c}\text { Ste } \\
(\mathbf{m g} / \mathbf{L})\end{array}$ & $\begin{array}{c}\text { Sbsa } \\
(\mathbf{m g} / \mathbf{L})\end{array}$ & $\begin{array}{c}\text { Sbpa } \\
(\mathbf{m g} / \mathbf{L})\end{array}$ & $\begin{array}{c}\text { Sba } \\
(\text { Sbsa+Sbpa) }\end{array}$ & $\begin{array}{c}\mathbf{f b s} \\
(\mathbf{S b s a} / \mathbf{S b a})\end{array}$ \\
\hline $\mathbf{2 0 1 3}$ & $744 \pm 191$ & $147 \pm 92$ & $246 \pm 36$ & $236 \pm 34$ & $538 \pm 40$ & $0,46 \pm 0,1$ \\
\hline $\mathbf{2 0 1 4}$ & $772 \pm 180$ & $133 \pm 62$ & $298 \pm 29$ & $273 \pm 31$ & $571 \pm 51$ & $0,52 \pm 0,1$ \\
\hline $\mathbf{2 0 1 5}$ & $708 \pm 106$ & $100 \pm 54$ & $233 \pm 34$ & $319 \pm 21$ & $552 \pm 36$ & $0,42 \pm 0,1$ \\
\hline & $\begin{array}{c}\mathbf{f b} \\
\mathbf{( S b a / S t a )}\end{array}$ & $\begin{array}{c}\mathbf{f b p} \\
\mathbf{( f b - f b s )}\end{array}$ & $\begin{array}{c}\mathbf{f}_{\mathrm{u}} \\
\left(\mathbf{1}-\mathbf{f}_{\mathbf{b}}\right)\end{array}$ & $\begin{array}{c}\mathbf{f}_{\text {us }} \\
\left(\mathbf{S}_{\text {te }} \mathbf{S}_{\text {ta }}\right)\end{array}$ & $\begin{array}{c}\mathbf{f}_{\text {up }} \\
\left(\mathbf{f}_{\mathbf{u}}-\mathbf{f}_{\text {us }}\right)\end{array}$ & \\
\hline $\mathbf{2 0 1 3}$ & $0,72 \pm 0,1$ & $0,27 \pm 0,1$ & $0,28 \pm 0,05$ & $0,20 \pm 0,05$ & $0,08 \pm 0,04$ & \\
\hline $\mathbf{2 0 1 4}$ & $0,74 \pm 0,1$ & $0,22 \pm 0,1$ & $0,26 \pm 0,10$ & $0,17 \pm 0,05$ & $0,09 \pm 0,10$ & \\
\hline $\mathbf{2 0 1 5}$ & $0,78 \pm 0,1$ & $0,36 \pm 0,1$ & $0,22 \pm 0,05$ & $0,14 \pm 0,05$ & $0,08 \pm 0,10$ & \\
\hline
\end{tabular}

*o detalhamento de cada termo está descrito na lista de símbolos

Os resultados mostram que houve uma diferença estreita entre as diversas frações que constituíram a matéria orgânica do esgoto afluente ao processo de lodos ativados. Com os dados do ano de 2015, construímos a Figura 86 que apresenta os valores médios em forma de fluxograma as respectivas frações de material orgânico do esgoto à entrada do processo de lodos ativados. 
Figura 86: Fluxograma geral referente às frações de material orgânico - 2015

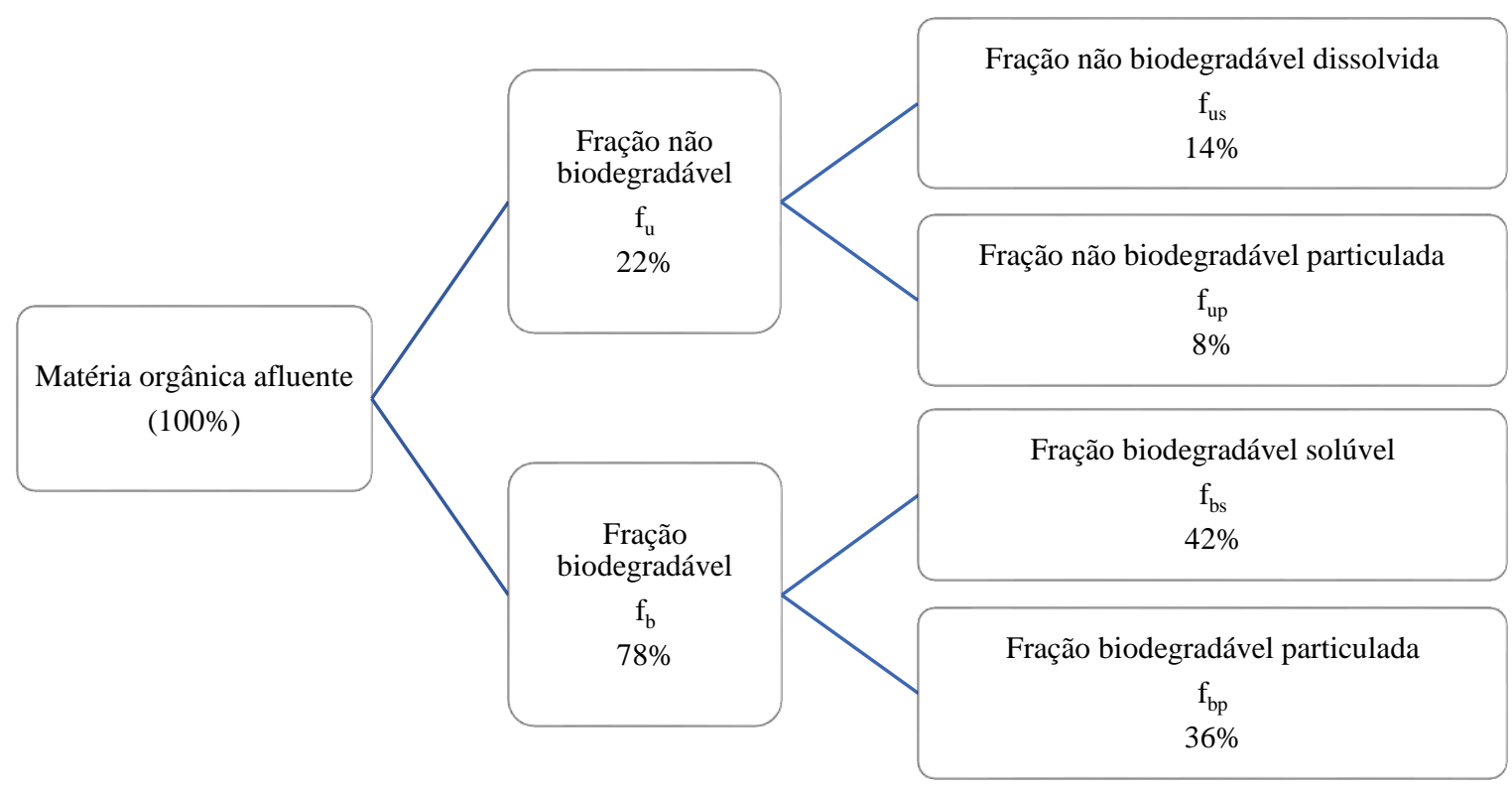

\subsubsection{Atividade Metabólica das Bactérias Heterotróficas.}

Com os dados obtidos pela respirometria e determinações analíticas, calcularam-se, para as os anos de 2013, 2014 e 2015 do sistema de lodo ativado, as constantes de crescimento específico máximo das bactérias heterotróficas $(\mu \mathrm{m})$ e as taxas de utilização de material orgânico das bactérias heterotróficas ( $\left.r_{\text {máx}}\right)$ que são apresentados na Tabela 56. As determinações seguiram o modelo descrito em van Haandel e Marais, 1999 e o detalhamento de cada termo está descrito na lista de símbolos.

Exemplificando-se, para o ano de 2015, tem-se os seguintes valores:

Médias da TCO obtida nos testes respirométricos com esgoto sanitário, sendo: $\mathrm{TCO}_{\mathrm{exo}}$ $=77 \mathrm{mg} \cdot \mathrm{L}^{-1} \cdot \mathrm{h}^{-1} \mathrm{e}$ TCO ${ }_{\text {end }}=14 \mathrm{mg} \cdot \mathrm{L}^{-1} \cdot \mathrm{h}^{-1}$.

A concentração de lodo ativo $\left(X_{a}\right)$ foi determinada de duas maneiras:

(1) Pela $\mathrm{TCO}_{\text {end }}$ obtida no teste respirométrico, com os seguintes valores:

$\mathrm{Y}=0,45 \mathrm{mgXa} \mathrm{mgDQO}^{-1} ; \mathrm{R}_{\mathrm{h}}=0,68 \mathrm{~d}^{-1} ; \mathrm{S}_{\mathrm{ta}}=708 \mathrm{mg} \cdot \mathrm{L}^{-1} ; \mathrm{b}_{\mathrm{h}}=0,24^{*} 1,04^{*(-20)} \mathrm{d}^{-1} ; \mathrm{R}_{\mathrm{s}}=12$ dias; $\mathrm{TCO}_{\text {end }}=14 \mathrm{mgO}^{-1} \cdot \mathrm{L}^{-1} ; \mathrm{f}_{\mathrm{cv}}=1,5 \mathrm{mgDQO} \mathrm{mgSSV}^{-1} ; \mathrm{f}=0,2$. 
Portanto, calcula-se $\left(\mathrm{X}_{\mathrm{a}}\right)$, como se segue:

(Equação 1)

$X_{a}=T_{C O}$ end $/\left[f_{c v}{ }^{*}(1-f)^{*} b_{h}\right]=\left(14^{*} 24 /\left[1,5^{*}(1-0,2)^{*} 0,24^{*} 1,04^{(26,5-20)}\right]=904 \mathrm{mgX}_{a .} L^{-1}\right.$

(2) Pela teoria de lodo ativado, tem-se:

(Equação 2)

$X_{a}=Y^{*} R_{h}{ }^{*} S_{t a} /\left(1+b_{h}{ }^{*} R_{s}\right)^{*} R_{h}=\left(0,45^{*} 0,68^{\star} 708 /\left(1+0,31^{*} 12\right)^{*} 0,68\right)^{\star} 24=750 \mathrm{mgX}_{a} \cdot L^{-1}$

Para melhor estimativa de $\left(\mathrm{X}_{\mathrm{a}}\right)$, utilizou-se a média dos resultados obtidos pelos dois métodos, onde os valores médios resultaram em $977 \mathrm{mgX} \mathrm{L}^{-1}$ (2013), $861 \mathrm{mgX}$. L${ }^{1}(2014)$ e $827 \mathrm{mgX}_{\mathrm{a}} \mathrm{L}^{-1}$ (2015).

Relação Xa/Xv: $977 / 2970=0,3$ (2013); 861/3146 = 0,3 (2014) e 827/3069 = 0,3 (2015).

Verifica-se o valor da fração ativa do lodo volátil inferior aos valores comumente encontrados em processos de lodos ativados, que são da ordem de 0,5 , em todos os anos.

Tabela 56: Valores médios das constantes cinéticas de utilização de material orgânico

Constantes cinéticas das bactérias heterotróficas

\begin{tabular}{|c|c|c|c|c|c|c|}
\hline \multirow[b]{2}{*}{ Variável } & \multicolumn{2}{|r|}{2013} & \multicolumn{2}{|r|}{2014} & \multicolumn{2}{|r|}{2015} \\
\hline & $\begin{array}{l}\mu_{\mathrm{m} 20} \\
\left(d^{-1}\right)\end{array}$ & $\begin{array}{c}r_{\text {máx }} \\
\left(m g D Q O \cdot m g X_{a} \cdot d^{-1}\right)\end{array}$ & $\begin{array}{l}\mu_{\mathrm{m} 20} \\
\left(d^{-1}\right)\end{array}$ & $\begin{array}{c}r_{\text {máx }} \\
\left(m g D Q O \cdot m g X_{a} \cdot d^{-1}\right)\end{array}$ & $\begin{array}{l}\mu_{\mathrm{m} 20} \\
\left(d^{-1}\right)\end{array}$ & $\begin{array}{c}r_{\text {max }} \\
\left(m g D Q O \cdot m g X_{a} \cdot d^{-1}\right)\end{array}$ \\
\hline média & 2,6 & 5,7 & 2,7 & 6,0 & 2,8 & 6,2 \\
\hline máxima & 3,5 & 7,7 & 3,8 & 8,2 & 4,4 & 8,5 \\
\hline mínima & 1,3 & 2,9 & 1,5 & 3,2 & 1,6 & 3,4 \\
\hline DP & 0,6 & 1,4 & 0,7 & 1,1 & 1,3 & 1,2 \\
\hline CV (\%) & 24,1 & 24,1 & 10,0 & 8,5 & 9,0 & 9,0 \\
\hline$n$ & \multicolumn{2}{|r|}{10} & \multicolumn{2}{|r|}{10} & \multicolumn{2}{|r|}{10} \\
\hline
\end{tabular}


Observa-se que praticamente não houve diferença entre os resultados médios da taxa de crescimento especifico máximo $\left(\mu_{\mathrm{m} 20}\right)$ das bactérias heterotróficas no período de estudo. Sendo de 2,6 d $\mathrm{d}^{-1}$ no ano de 2013, de 2,7 $\mathrm{d}^{-1}$ no ano de 2014 e de 2,8 $\mathrm{d}^{-1}$ para o ano de 2015. Esses valores são compatíveis aos encontrados na literatura $\mu_{\mathrm{m} 20=}$ $\left(1,5-7,2 d^{-1}\right)$. Isto significa, que a baixa concentração de OD no tanque de aeração e as condições propostas para obtenção do processo de NDS não afetou negativamente o crescimento das bactérias heterotrófica do processo de lodos ativados.

\subsubsection{Verificação do balanço de massa para validação do teste respirométrico sob baixas concentrações de oxigênio dissolvido}

Inicialmente, para validar os dados obtidos, verificou-se se a TCO exercida corresponde à concentração do substrato adicionado. Foram realizados testes iniciais para cada substrato (cloreto de amônio e nitrito de sódio), para verificar se o balanço entre a área abaixo da curva da TCO e a concentração adicionada de substratos são consistentes no ambiente proposto de 0,3 a 1,0 mgO$/ \mathrm{L}$ de oxigênio dissolvido. Conforme o procedimento apresentado na seção $X$ do capítulo $X$, foi adicionado nos testes uma concentração de uma solução padrão de (10 mgN.L ${ }^{-1}$ ) (amônia e nitrito) para nitritantes e nitratantes. Para a curva referente às nitritadoras, a área média calculada foi de 44,2 mgO2. $\mathrm{L}^{-1}$, o que representa, estequiometricamente, uma concentração de $(44,2 / 4,57)=9,67 \mathrm{mgN} \cdot \mathrm{L}^{-1}$. Da mesma forma, com a curva correspondente as nitratadoras, encontra-se uma área média de $11,2 \mathrm{mgO}_{2} . \mathrm{L}^{-1}$, o que representa, estequiometricamente, uma concentração de $(11,4 / 1,14)=9$,82 mgN.L-1. Ambos os testes apresentaram um valor alto de recuperação $(96,7 \%)$ nitritantes e $(98,2 \%)$ nitratantes, logo, conclui-se que o consumo de oxigênio foi compatível com a demanda pelo substrato adicionado, validando o teste para as condições estabelecidas neste estudo com baixa concentração de OD. A Figura 87 mostra um exemplo de um dos testes realizado com adição de cloreto de amônio e nitrito de sódio. 
Figura 87: Exemplo de Respirograma para determinação de constantes cinéticas das bactérias autotróficas.

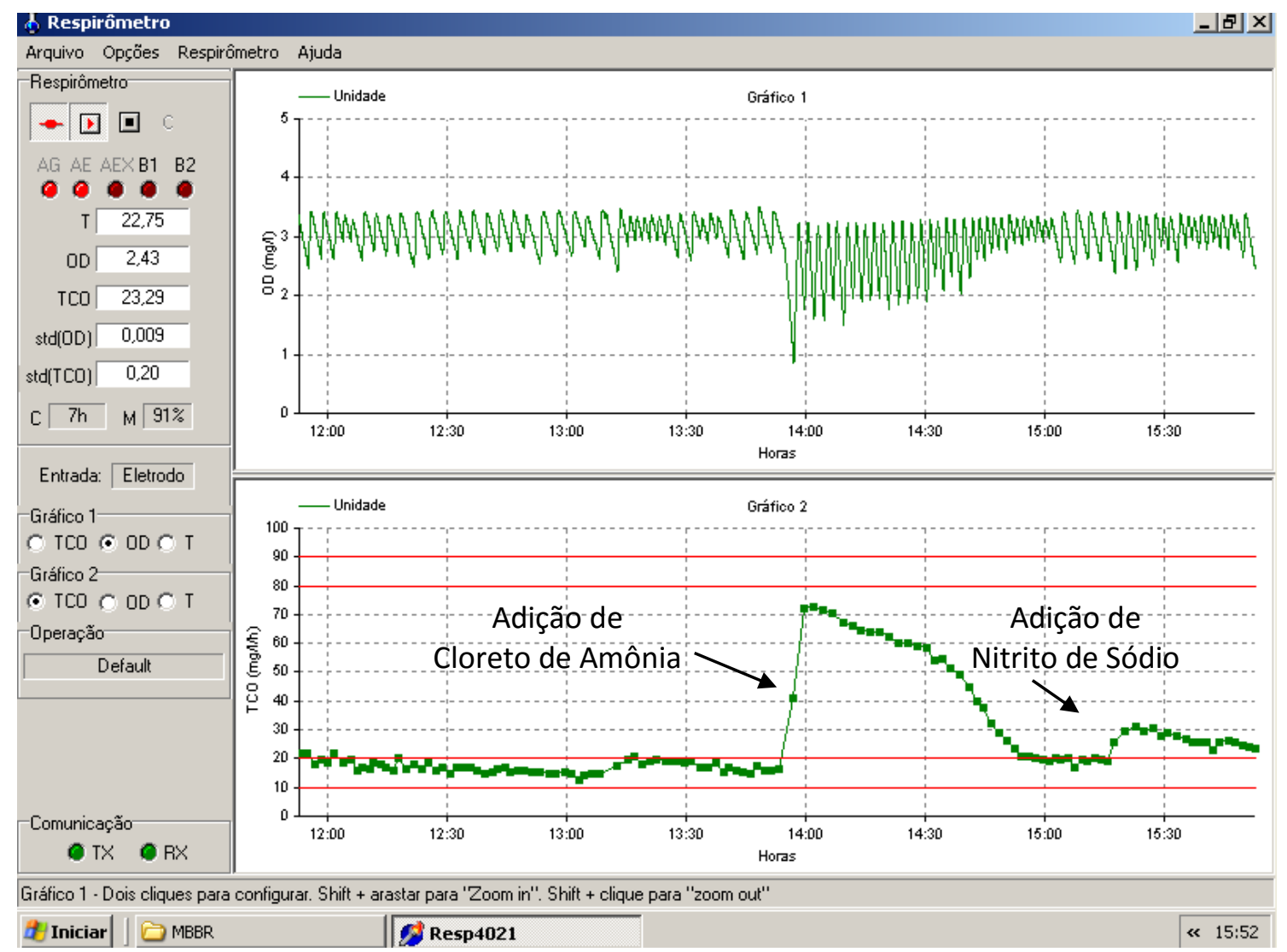

\subsubsection{Constantes cinéticas das bactérias autotróficas nitritantes e nitratantes}

Com os dados obtidos pela Respirometria e determinações analíticas, calcularam-se, para os anos de 2013, 2014 e 2015, as constantes de crescimento específico máximo $\left(\mu_{\mathrm{m}}\right)$, as de meia saturação de Monod $\left(\mathrm{K}_{\mathrm{n}}\right)$ e a taxa máxima de utilização de amônia e nitrito ( $r_{\text {n.máx }}$ ) para as para as bactérias oxidadoras de amônia (BOA) e nitrito (BON), (conforme descrito na seção $X$ do capítulo $X$ ). Para constante de decaimento $\left(b_{n}\right)$ foi adotado um valor típico de $0,04^{*} 1,04^{(T-20)}$, sugerido por EKAMA \& MARAIS (1976), conforme apresentado no item 4 . Os dados apresentados foram corrigidos para uma temperatura de $20^{\circ} \mathrm{C}$. 
Nas Tabelas 57 e 58, apresentam-se os resultados médios da taxa de consumo de oxigênio exógena ( $\mathrm{TCO}_{\mathrm{exo}}$ ) e a taxa de consumo de oxigênio máxima ( $\mathrm{TCO}_{\text {n.máx }}$ ) devido ao consumo de amônia e nitrito, respectivamente.

Tabela 57: Valores médios da TCO pelas bactérias oxidadoras de amônia

\begin{tabular}{|c|c|c|c|c|c|c|}
\hline \multicolumn{7}{|c|}{ Taxa de consumo de oxigênio pelas bactérias oxidadoras de amônia } \\
\hline \multirow[b]{2}{*}{ Variáveis } & \multicolumn{2}{|c|}{2013} & \multicolumn{2}{|c|}{2014} & \multicolumn{2}{|c|}{2015} \\
\hline & $\begin{array}{c}\mathrm{TCO}_{\mathrm{exo}} \\
\mathrm{mgO}_{2 \cdot \mathrm{L}^{-1} \cdot \mathrm{h}^{-1}}\end{array}$ & $\begin{array}{c}\mathrm{TCO}_{n \cdot \max } \\
\mathrm{mgO}_{2 \cdot \mathrm{L}^{-1} .} \cdot \mathrm{h}^{-1}\end{array}$ & $\begin{array}{c}\text { TCO }{ }_{\text {end }} \\
\mathrm{mgO}_{2 \cdot \mathrm{L}^{-1} .} \cdot \mathrm{h}^{-1}\end{array}$ & $\begin{array}{c}\mathrm{TCO}_{\text {n.máx }} \\
\mathrm{mgO}_{2 \cdot \mathrm{L}^{-1} \cdot \mathrm{h}^{-1}}\end{array}$ & $\begin{array}{c}\mathrm{TCO}_{\text {exo }} \\
\mathrm{mgO}_{2 \cdot \mathrm{L}^{-1} \cdot \mathrm{h}^{-1}}\end{array}$ & $\begin{array}{c}\mathrm{TCO}_{\text {n.máx }} \\
\mathrm{mgO}_{2 . \mathrm{L}^{-1} \cdot \mathrm{h}^{-1}}\end{array}$ \\
\hline média & 34 & 18 & 33 & 19 & 32 & 18 \\
\hline máximo & 42 & 26 & 45 & 31 & 44 & 30 \\
\hline mínimo & 25 & 9 & 22 & 8 & 22 & 8 \\
\hline DP & 5 & 5 & 7 & 7 & 7 & 7 \\
\hline CV (\%) & 15 & 29 & 20 & 34 & 22 & 40 \\
\hline $\mathrm{n}$ & \multicolumn{2}{|c|}{10} & \multicolumn{2}{|c|}{10} & \multicolumn{2}{|c|}{10} \\
\hline
\end{tabular}

${ }^{*} \mathrm{TCO}_{\text {endógena }}=16,0 \mathrm{mgO}_{2} \cdot \mathrm{L}^{-1} \cdot \mathrm{h}^{-1}(2013) ; \mathrm{TCO}_{\text {endógena }}=14,0 \mathrm{mgO}_{2} \cdot \mathrm{L}^{-1} \cdot \mathrm{h}^{-1}(2014 \mathrm{e}$ 2015).

Tabela 58: Valores médios da TCO pelas bactérias oxidadoras de nitrito

\begin{tabular}{|c|c|c|c|c|c|c|}
\hline \multicolumn{7}{|c|}{ Taxa de consumo de oxigênio pelas bactérias oxidadoras de nitrito } \\
\hline \multirow[b]{2}{*}{ Variáveis } & \multicolumn{2}{|c|}{2013} & \multicolumn{2}{|c|}{2014} & \multicolumn{2}{|c|}{2015} \\
\hline & $\begin{array}{c}\mathrm{TCO}_{\mathrm{exo}} \\
\mathrm{mgO}_{2} \cdot \mathrm{L}^{-1} \cdot \mathrm{h}^{-1}\end{array}$ & $\begin{array}{c}\mathrm{TCO}_{\text {n.máx }} \\
\mathrm{mgO}_{2 \cdot \mathrm{L}^{-1} \cdot \mathrm{h}^{-1}}\end{array}$ & $\begin{array}{c}\mathrm{TCO}_{\text {end }} \\
\mathrm{mgO}_{2} \cdot \mathrm{L}^{-1} \cdot \mathrm{h}^{-1}\end{array}$ & $\begin{array}{c}\mathrm{TCO}_{\text {n.máx }} \\
\mathrm{mgO}_{2} \cdot \mathrm{L}^{-1} \cdot \mathrm{h}^{-1}\end{array}$ & $\begin{array}{c}\mathrm{TCO}_{\text {exo }} \\
\mathrm{mgO}_{2} \cdot \mathrm{L}^{-1} \cdot \mathrm{h}^{-}\end{array}$ & $\begin{array}{c}\mathrm{TCO}_{n . \text { max }} \\
\mathrm{mgO}_{2 . \mathrm{L}^{-1} \cdot \mathrm{h}^{-1}}\end{array}$ \\
\hline média & 21 & 5 & 19 & 5 & 20 & 6 \\
\hline máximo & 26 & 10 & 22 & 8 & 25 & 11 \\
\hline mínimo & 17 & 1 & 16 & 2 & 16 & 2 \\
\hline DP & 3 & 3 & 2 & 2 & 3 & 3 \\
\hline CV (\%) & 14 & 58 & 12 & 46 & 16 & 55 \\
\hline $\mathrm{n}$ & \multicolumn{2}{|c|}{10} & \multicolumn{2}{|c|}{10} & \multicolumn{2}{|c|}{10} \\
\hline
\end{tabular}

${ }^{*} \mathrm{TCO}_{\text {endógena }}=16,0 \mathrm{mgO}_{2} \cdot \mathrm{L}^{-1} \cdot \mathrm{h}^{-1}(2013) ; \mathrm{TCO}_{\text {endógena }}=14,0 \mathrm{mgO}_{2} \cdot \mathrm{L}^{-1} \cdot \mathrm{h}^{-1}(2014 \mathrm{e}$ 2015).

No período de 2013 a 2015, não houve variação significativa nos resultados médios de $\mathrm{TCO}_{\text {exo }}$ e TCOn.máx para as bactérias oxidadoras de amônia e de nitrito. Esses 
valores foram utilizados para as determinações das taxas de crescimento específico máximas das BOA e das BON $\left(\mu_{m}\right)$, dos coeficientes de meia saturação $\left(K_{n}\right)$ e das taxas máximas de utilização de amônia e nitrito ( $\mathrm{r}_{\text {n.máx }}$ ), apresentadas nas Tabela 59 e 60. As determinações seguiram o modelo descrito em van Haandel e Marais, 1999 e o detalhamento de cada termo está descrito na lista de símbolos.

Exemplificando-se, para o ano de 2015, tem-se os seguintes valores:

$f_{n}=$ adotado 0,10 (VAN HAANDEL e MARAIS,1999); $R s=12$ dias; $V_{r}=27.570 .000 \mathrm{~L}^{-1}$; $\mathrm{NTK}_{\mathrm{a}}=44,0 \mathrm{mgN}-\mathrm{NTK} . \mathrm{L}^{-1} ; \mathrm{NTK}_{\mathrm{e}}=5,0 \mathrm{mgN}-\mathrm{NTK} . \mathrm{L}^{-1} ; \mathrm{X}_{\mathrm{v}}=3.069 \mathrm{mgSSV} . \mathrm{L}^{-1} ; \mathrm{Q}_{\mathrm{a}}=$ $41.080 .435 \mathrm{~L}^{-d^{-1}} ; \mathrm{Y}_{n}=0,1 ; \mathrm{b}_{\mathrm{n}}=0,04(1,04)^{(26,5-20)} ; \mathrm{TCO}_{\text {exo }}=32,0 \mathrm{mgO}_{2} \cdot \mathrm{L}^{-1} \cdot \mathrm{h}^{-1} ; \mathrm{TCO}_{\text {end }}=$ $14,0 \mathrm{mgO}_{2} \cdot \mathrm{L}^{-1} \cdot \mathrm{h}^{-1}$.

Portanto calcula-se:

Concentração das bactérias autotróficas:

$X_{n}=Y_{n} R_{s} N_{c} /\left(1+b_{n} R_{s}\right) R_{h}=0,1^{*} 12^{*} 21,8 /\left(1+0,05^{\star} 12\right)^{*} 0,67=24,10 m g X_{n} \cdot L^{-1}$

Concentração de amônia nitrificada:

$N_{c}=N T K_{a}-N T K_{e}-N_{l}=44,0-5,0-17,2=21,8 m g N \cdot L^{-1}$

Concentração de nitrogênio necessário para a produção de lodo:

$\mathrm{N}_{\mathrm{l}}=\mathrm{f}_{\mathrm{n}} \mathrm{X}_{\mathrm{v}} \mathrm{V}_{\mathrm{r}} / \mathrm{R}_{\mathrm{s}} \mathrm{Q}_{\mathrm{a}}=0,1 * 3 \cdot 069^{*} 27 \cdot 570 \cdot 000 / 10,3^{*} 41 \cdot 080 \cdot 435=17,2 \mathrm{mgN} \cdot \mathrm{L}^{-1}$

TCO máxima das bactérias nitritantes obtida por meio dos testes respirométricos:

TCOn.máx $=$ TCOexo $-\mathrm{TCO}_{\text {end }}=32-14=18 \mathrm{mgO} \cdot \mathrm{L}^{-1} \cdot \mathrm{h}^{-1}$

Conforme o modelo cinético utilizado como referência (VAN HAANDEL e MARAIS,1999), pode-se calcular a taxa máxima de nitritação e nitratação como se segue: 
$r_{n}=$ TCOn.máx $/ 4,57=18 / 4,57=3,9 \mathrm{mg} \cdot \mathrm{L}^{-1} \cdot \mathrm{h}^{-1}$ ou $96,4 \mathrm{mg} \cdot \mathrm{L}^{-1} \cdot \mathrm{d}^{-1}$

Portanto, se calcula a taxa máxima de crescimento das BOA $\left(\mu_{\mathrm{m}}\right)$ como se segue:

$\mu_{m 20}=\left(Y_{n}{ }^{*} r_{n \cdot m a ́ x} / X_{n}\right)^{*} 24=(0,1 * 3,9 * 24,0 / 24,1)=0,39 d^{-1}$

Tabela 59: Valores médios das constantes de crescimento específico máximo das bactérias oxidadoras de amônia $\left(\mu_{\mathrm{m} 20)}\right.$.

\begin{tabular}{|c|c|c|c|c|c|c|c|c|c|}
\hline \multirow{3}{*}{$\begin{array}{l}\text { Variáveis } \\
\text { Frações }\end{array}$} & \multicolumn{9}{|c|}{$\operatorname{BOA}\left(d^{-1}\right)$} \\
\hline & \multicolumn{3}{|c|}{2013} & \multicolumn{3}{|c|}{2014} & \multicolumn{3}{|c|}{2015} \\
\hline & $\mu_{\mathrm{m} 20}$ & $\mathrm{~K}_{\mathrm{n} 20}$ & rn.máx & $\mu_{\mathrm{m} 20}$ & $\mathrm{~K}_{\mathrm{n} 20}$ & rn.máx & $\mu_{\mathrm{m} 20}$ & $\mathrm{~K}_{\mathrm{n} 20}$ & rn.máx \\
\hline média & 0,50 & 0,98 & 93 & 0,43 & 0,85 & 102 & 0,39 & 0,80 & 96 \\
\hline máximo & 0,73 & 2,30 & 137 & 0,68 & 1,80 & 163 & 0,65 & 1,30 & 158 \\
\hline mínimo & 0,25 & 0,50 & 47 & 0,18 & 0,40 & 42 & 0,17 & 0,50 & 42 \\
\hline DP & 0,14 & 0,53 & 27 & 0,15 & 0,45 & 35 & 0,16 & 0,31 & 38 \\
\hline CV (\%) & 29 & 54 & 29 & 34 & 53 & 34 & 40 & 38 & 40 \\
\hline$n$ & \multicolumn{3}{|c|}{10} & \multicolumn{3}{|c|}{10} & \multicolumn{3}{|c|}{10} \\
\hline
\end{tabular}

Tabela 60: Valores médios das constantes de crescimento específico máximo das bactérias oxidadoras de nitrito $\left(\mu_{\mathrm{m} 20}\right)$.

\begin{tabular}{c|c|c|c|c|c|c|c|c|c}
\hline \multirow{2}{*}{ Variáveis } & \multicolumn{7}{c}{ BON (d-1) } \\
\cline { 2 - 10 } & \multicolumn{3}{|c}{2013} & \multicolumn{3}{c}{2014} & \multicolumn{3}{c}{2015} \\
\hline Frações & $\mu_{m 20}$ & $K_{\text {n20 }}$ & $r_{\text {n.máx }}$ & $\mu_{\text {m20 }}$ & $K_{\text {n20 }}$ & $r_{\text {n.máx }}$ & $\mu_{\text {m20 }}$ & $K_{\text {n20 }}$ & rn.máx \\
\hline média & 0,55 & 0,62 & 4,0 & 0,41 & 0,59 & 4,0 & 0,49 & 0,67 & 119 \\
\hline máximo & 1,12 & 1,26 & 9,0 & 0,71 & 1,10 & 7,0 & 0,96 & 1,10 & 232 \\
\hline mínimo & 0,11 & 0,18 & 1,0 & 0,18 & 0,30 & 1,7 & 0,17 & 0,18 & 42,11 \\
\hline DP & 0,32 & 0,34 & 2,5 & 0,19 & 0,26 & 1,9 & 0,27 & 0,29 & 65 \\
\hline CV (\%) & 58 & 56 & 58 & 47 & 45 & 46 & 55 & 44 & 55 \\
\hline $\mathrm{n}$ & & 10 & & & 10 & & & 10 & \\
\hline
\end{tabular}

Os resultados obtidos nesse estudo pode ser considerado bastante parecido quando se compara com a faixa prevista para $\mu_{\text {máx,N }}$ entre $0,20-1,02 \mathrm{~d}^{-1}$ por Barnard (1991); Kayser (1991); Eckenfelder (1992); Sutton et al, (1979); Gujer (1977); Ekama \& Marais 
(1976); Poduska \& Andrews (1974); Gujer \& Jenkins (1975); Lawrence \& Brown (1973); Lljkelma (1973); Downing et al, (1964) e Metcalf \& Eddy (2003).

\subsection{Biologia Molecular aplicada ao processo de lodos ativados}

Durante o ano de 2015 foram coletadas amostras do lodo ativado para avaliação das bactérias nitrificantes e desnitrificantes no processo de NDS, por meio da técnica de FISH. As Figuras 88, 89 e 90 mostram os resultados da análise de biologia molecular, para as bactérias nitritantes, nitratantes e desnitrificantes, respectivamente.

Figura 88: Teste de presença ou ausência de bactérias nitritantes no processo de NDS.
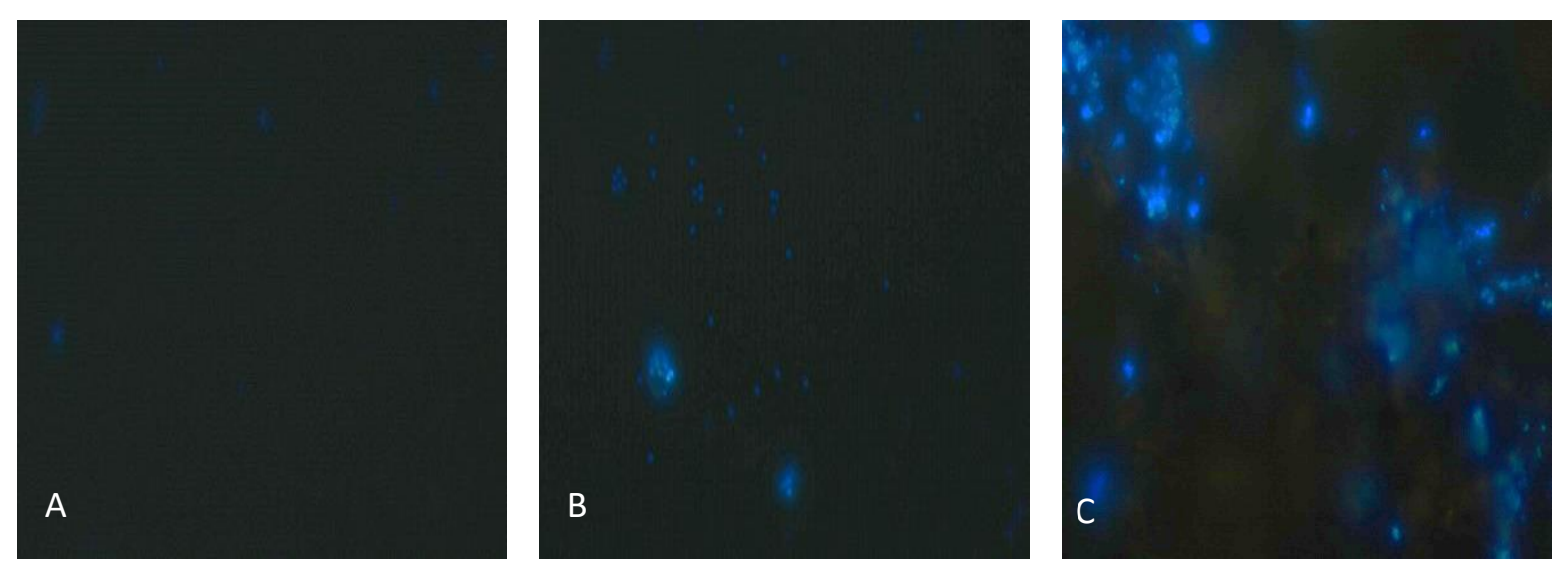

Legenda: Porção inicial (A), porção média (B) e porção final do tanque de aeração (C).

Figura 89: Teste de presença ou ausência de bactérias nitratantes no processo de NDS.
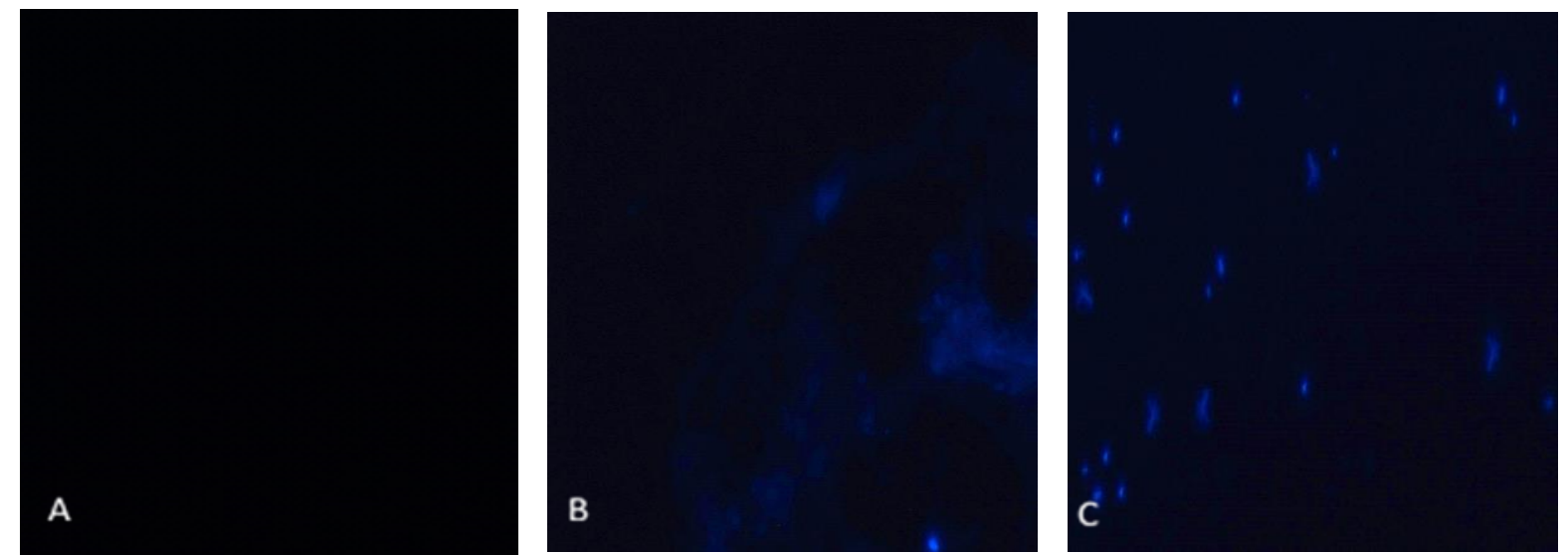

Legenda: Porção inicial (A), porção média (B) e porção final do tanque de aeração (C). 
Figura 90: Teste de presença ou ausência de bactérias desnitrificantes no processo de NDS.
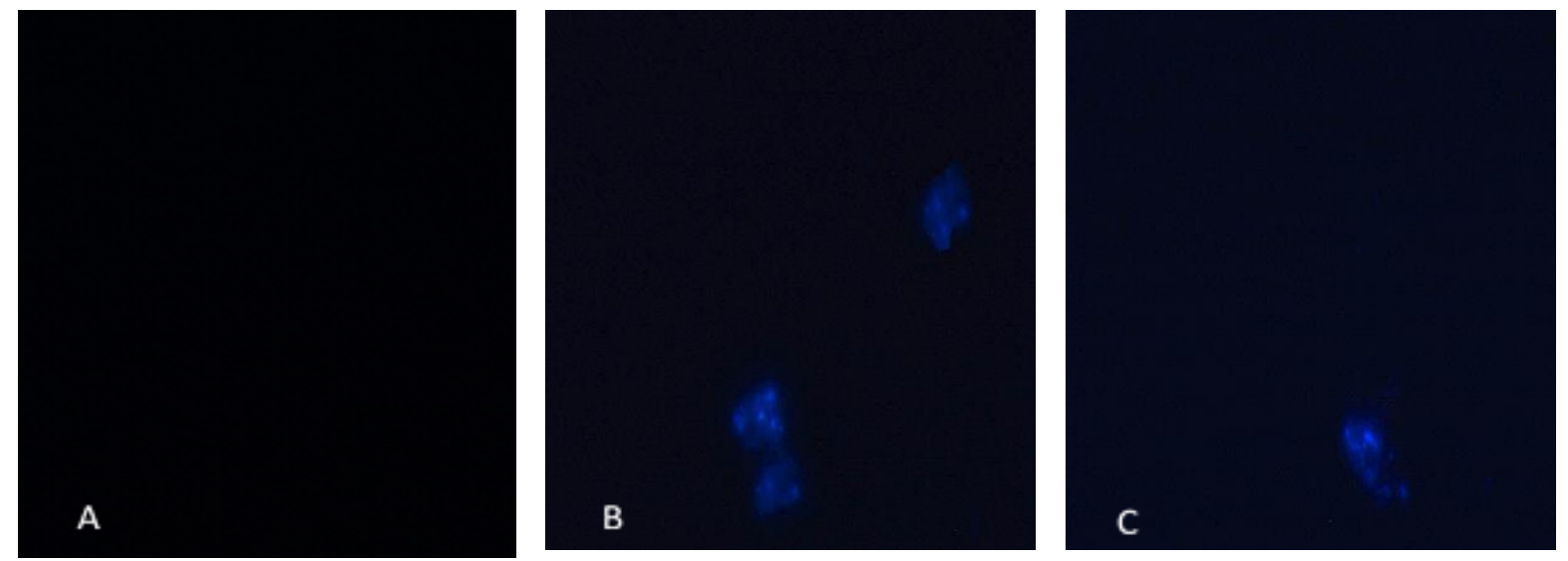

Legenda: Porção inicial (A), porção média (B) e porção final do tanque de aeração (C).

Os resultados dos testes de biologia molecular indicam a presença das bactérias nitrificantes e desnitrificantes no processo de lodos ativados. Embora, a baixa resolução das imagens apresentadas nas figuras, observa-se em ambos os casos que no início do tanque de aeração não há praticamente presença de bactérias nitrificantes e desnitrificantes e que esses grupos começam a aparecer nas porções médias e principalmente no final do tanque de aeração, onde a disponibilidade de OD é maior, com exceção às bactérias desnitrificantes que foram visualizadas em sua maior parte na porção média do tanque. A presença dos microrganismos junto aos resultados obtidos de remoção de nitrogênio, confirmam a ocorrência da nitrificação e desnitrificação simultânea no processo de lodos ativados.

\subsection{Uso de energia para aeração do processo de lodos ativados}

Considerando-se a necessidade de oxigênio igual a $1,5 \mathrm{kgO}_{2} / \mathrm{kgDBO}_{\text {aplicada, }}$ para o ano de 2015 (carga média de 14.159 kgDBOaplicada/dia) e (carga máxima de 32.034

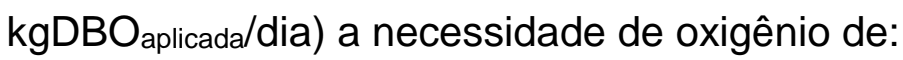

Nec. $\mathrm{O}_{2}=(1,5 \times 14.159) / 24=885 \mathrm{kgO} / \mathrm{hora}(\mathrm{p} / \mathrm{Qmédia})$;

Nec. $\mathrm{O}_{2}=(1,5 \times 32.034) / 24=2.002$ kgO$/$ hora $(\mathrm{p} /$ Qmáxima $)$; 
Considerando-se a massa específica do ar igual a $1,2 \mathrm{~kg} / \mathrm{m}^{3}$, a porcentagem de $\mathrm{O}_{2}$ de $23,2 \%$ e o rendimento do soprador de $8 \%$ (sopradores do tipo roots, RBS126), a vazão necessária de ar foi de:

Qar.média $=885 /(1,2 \times 0,232 \times 0,08 \times 60)=663 \mathrm{Nm}^{3}$.ar/minuto ou $39.780 \mathrm{Nm}^{3}$.ar/hora Qar.máxima $=2.002 /(1,2 \times 0,232 \times 0,08 \times 60)=1.498 \mathrm{Nm}^{3}$.ar/minuto ou 89.880 $\mathrm{Nm}^{3}$.ar/hora

Conforme apresentado no Item 4 a capacidade total de vazão de ar dos sopradores é de $30.600 \mathrm{Nm}^{3}$.ar/hora. Valor que não atende as demandas de OD para operação em condições normais de um processo de lodos ativados com aeração prolongada. Com a otimização do sistema de lodos ativados e adotando-se a estratégia de operação do processo com baixa aeração nos tanques de aeração. A necessidade de oxigênio passou a ser:

Nec. $\mathrm{O}_{2}=(0,5 \times 14.159) / 24=295$ kgO$/$ hora $(\mathrm{p} /$ Qmédia $)$;

$\mathrm{Nec} . \mathrm{O}_{2}=(0,5 \times 32.034) / 24=667 \mathrm{kgO} / \mathrm{hora}\left(\mathrm{p} / \mathrm{Q}_{\text {máxima }}\right)$;

Considerando-se a massa específica do ar igual a $1,2 \mathrm{~kg} / \mathrm{m}^{3}$, a porcentagem de $\mathrm{O}_{2}$ de $23,2 \%$ e o rendimento do soprador de $8 \%$ (sopradores do tipo roots, RBS126), a vazão necessária de ar foi de:

Qar.média $=295 /(1,2 \times 0,232 \times 0,08 \times 60)=221 \mathrm{Nm}^{3}$.ar/minuto ou $13.260 \mathrm{Nm}^{3}$.ar/hora Qar.máxima $=667 /(1,2 \times 0,232 \times 0,08 \times 60)=499 \mathrm{Nm}^{3}$.ar/minuto ou $29.940 \mathrm{Nm}^{3}$.ar/hora

Neste novo arranjo os cálculos demostram que o fornecimento de ar pelos sopradores é compatível para atender a demanda de OD nas vazões média e de pico. Essa condição foi um fator que levou a escolha da pesquisa na ETE Limoeiro, pois o 
processo de lodos ativados estava obrigatoriamente sob condições de baixa a aeração nos tanques, no entanto, sem controle do processo de NDS.

A potência nominal dos sopradores com o motor a uma rotação de $1750 \mathrm{rpm}$ é de 735 kw, ou 147 kw cada. Uma das maneiras de se reduzir o consumo de energia elétrica em motores é alterar a sua velocidade. Essa variação foi possível por meio de inversores de frequência existentes na ETE. Considerando as curvas do soprador e as observações realizadas em campo temos:

Rotação nominal do motor do soprador:

$(\mathrm{N} 1)=1.750 \mathrm{rpm}$;

Rotação reduzida para atender as novas condições de aeração no tanque para vazão média:

$(\mathrm{N} 2)=1150 \mathrm{rpm}$ (valor observado em campo);

* rotação de partida do motor $=859 \mathrm{rpm}$

Potencia nominal dos sopradores:

$(P 1)=735 \mathrm{kw}$

Reduzindo-se a rotação para $48 \%$ da nominal teremos o novo valor de potência de:

$\mathrm{P}_{2}=\left(\mathrm{N}_{2} / \mathrm{N}_{1}\right)^{3} \times \mathrm{P}_{1}=(1150 / 1750)^{3} \times 735=209 \mathrm{kw}$

Potência consumida na rotação nominal $\left(P_{c}\right)$ :

Vazão de ar total dos sopradores $=510 \mathrm{~m}^{3} / \mathrm{h}$ ou $12.240 \mathrm{~m}^{3} / \mathrm{dia}$;

Tempo de fornecimento de ar para encher os tanques de aeração:

$27.570 \mathrm{~m}^{3} / 510 \mathrm{~m}^{3} / \mathrm{h}=54$ horas

$P_{c}=54 \times 735=39.690 \mathrm{kwh}$

Potência reduzida $\left(\mathrm{Pr}_{\mathrm{r}}\right)$ : 
Vazão de ar total dos sopradores $=220 \mathrm{~m}^{3} / \mathrm{h}$ ou $5.280 \mathrm{~m}^{3} / \mathrm{dia}$;

Tempo de fornecimento de ar para encher os tanques de aeração:

$27.570 \mathrm{~m}^{3} / 220 \mathrm{~m}^{3} / \mathrm{h}=125$ horas

$\operatorname{Pr}=125 \times 209=26.125 \mathrm{kwh}$

Assim temos:

Energia economizada $=(1-(26.125 / 39.690)) * 100=34 \%$ de economia.

Esse valor é compatível aos relatados na literatura para sistemas operados com baixa aeração que pode chegar a uma economia de energia elétrica entre 30 a 40\% (PENG ZHANG E ZHOU QI, 2007; THAURÉ et al., 2008; BUENO, 2011).

\subsection{CONTROLE LABORATORIAL E MONITORAMENTO DAS PRINCIPAIS VARIÁVEIS EXERCIDAS NO PROCESSO DE LODO ATIVADO DA ETE PILOTO}

\subsubsection{Vazão de esgoto da ETE - Piloto}

A vazão do esgoto à entrada da ETE piloto foi controlada por meio de inversor de frequência e os registros e ajustes foram feitos diariamente. Na Figura 91, apresentase os resultados da vazão na forma de série temporal com médias móveis de 4 termos. Com esses dados construímos a Figura 92 e a Tabela 61 onde observa-se as médias e os desvios analíticos durante o período. 
Figura 91: Série temporal da vazão de esgoto à entrada e à saída do processo de lodos ativados da ETE Piloto.

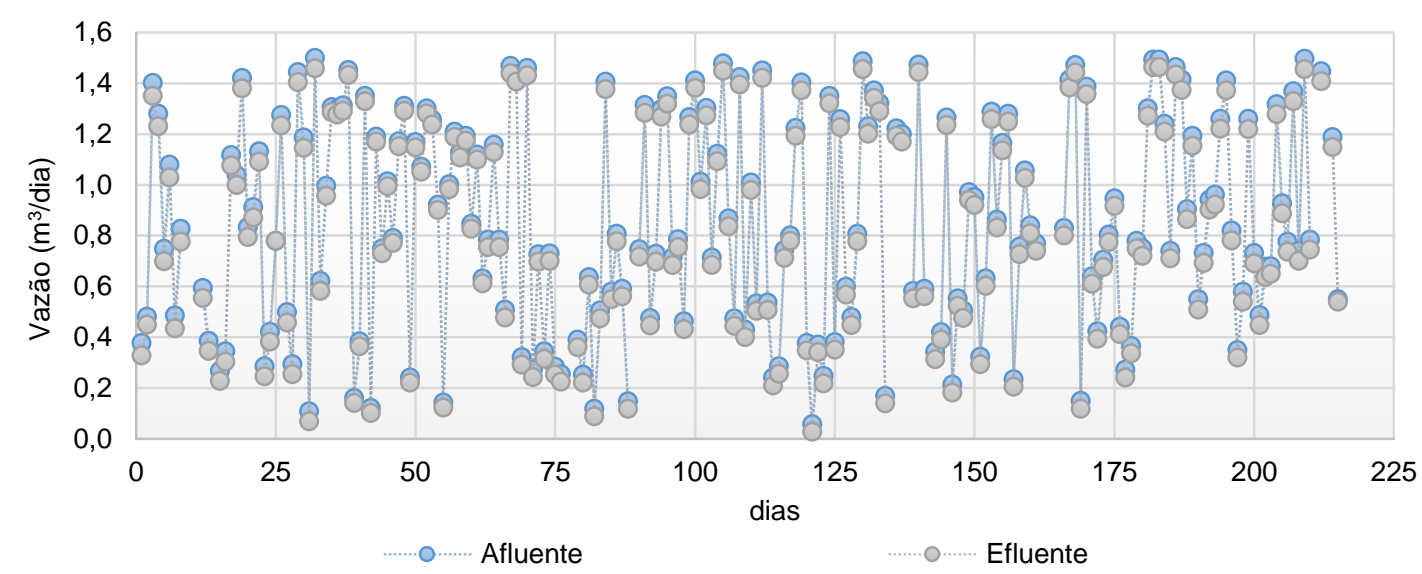

Tabela 61: Valores médios da vazão de entrada e saída do processo de lodos ativados da ETE Piloto

\begin{tabular}{c|c|c}
\hline \multicolumn{3}{|c}{ Vazão $\left(\mathrm{m}^{3} / \mathrm{d}\right)$} \\
\hline Variável & Afluente & Efluente \\
\hline Média & 0,78 & 0,76 \\
\hline máximo & 1,50 & 1,46 \\
\hline mínimo & 0,06 & 0,03 \\
\hline DP & 0,40 & 0,40 \\
\hline CV $(\%)$ & 48,0 & 50,0 \\
\hline $\mathrm{N}$ & 199 & 199 \\
\hline \multicolumn{3}{|}{}
\end{tabular}

Figura 92: Diagramas Box-Whiskers da vazão de entrada e saída do processo de lodos ativados da ETE Piloto

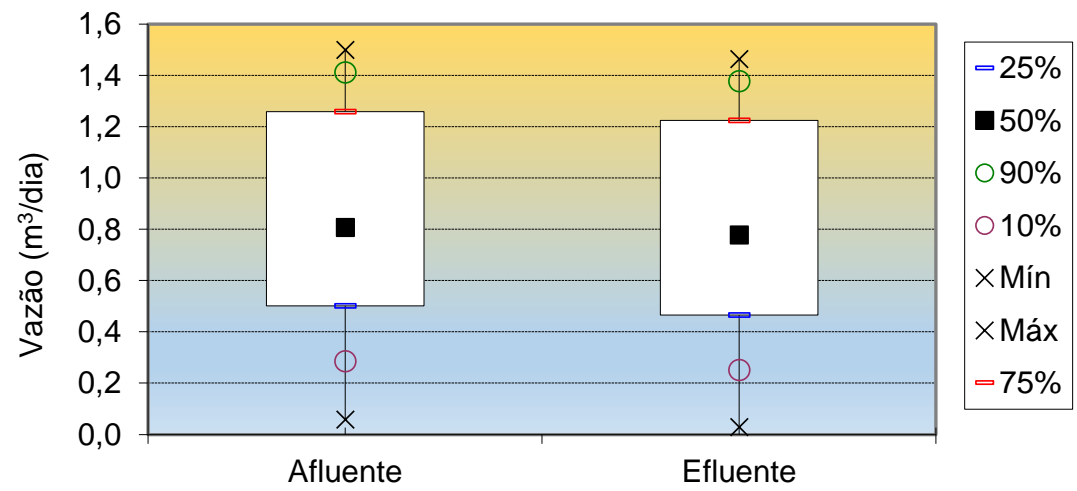


A vazão média de esgoto à entrada da ETE foi de $0,78 \mathrm{~m}^{3} / \mathrm{dia}$. Compondo-se a vazão média com a $\mathrm{DBO}_{5}$ do esgoto afluente de $361 \mathrm{mg} / \mathrm{L}$ e DQO de $737 \mathrm{mg} / \mathrm{L}$, tem-se: carga de 0,28 kgDBO/dia e 0,57 kgDQO/dia. Em decorrência da carga orgânica afluente e do controle exercido sobre a idade do lodo, as concentrações de sólidos em suspensão totais e voláteis resultantes no tanque de aeração são apresentadas na Tabela 62.

Tabela 62: Concentrações de sólidos em suspensão e suas frações nos tanques de aeração

\begin{tabular}{c|c|c|c}
\hline \multicolumn{4}{c}{ Sólidos em Suspensão - (mg/L) } \\
\hline Variável & Total & Fixo & Volátil \\
\hline Média & 4564 & 1290 & 3274 \\
\hline Máximo & 7460 & 2443 & 5020 \\
\hline Mínimo & 1724 & 183 & 1555 \\
\hline DP & 880 & 493 & 557 \\
\hline CV $(\%)$ & 15 & 15 & 15 \\
\hline $\mathrm{N}$ & \multicolumn{4}{|c}{}
\end{tabular}

Os resultados de sólidos foram muito próximos aos obtidos em escala real, foi possível manter uma concentração elevada no tanque de aeração com valor médio de 3.274 $\mathrm{mg} / \mathrm{L}$, valor típico de lodos ativados com aeração prolongada. A relação SSV/SST resultou em 0,72 no lodo do tanque, este número está associado a um bom nível de digestão do lodo, sendo possível a secagem sem digestão complementar. Considerando-se a carga de DBO de 0,28 kgDBO/dia e a concentração média de SSV de $3.274 \mathrm{mg} / \mathrm{L}$ e o volume útil do tanque de aeração de $0,5 \mathrm{~m}^{3}$, a relação alimento/microrganismos resultante foi de $0,17 \mathrm{kgDBO} / \mathrm{kgSSV} . \mathrm{d}$.

\subsubsection{Sólidos em suspensão totais no efluente da ETE}

Na Figura 93 apresenta-se as concentrações em série temporal das concentrações de sólidos em suspensão totais no efluente à saída do processo de lodos ativados da ETE Piloto e, com os dados das determinações da série de sólidos, construímos a Tabela 63 e a Figura 94, onde observa-se os valores estatísticos obtidos no período de estudo. 
Figura 93: Série temporal com médias móveis de 4 termos das concentrações de sólidos no efluente à saída da ETE Piloto

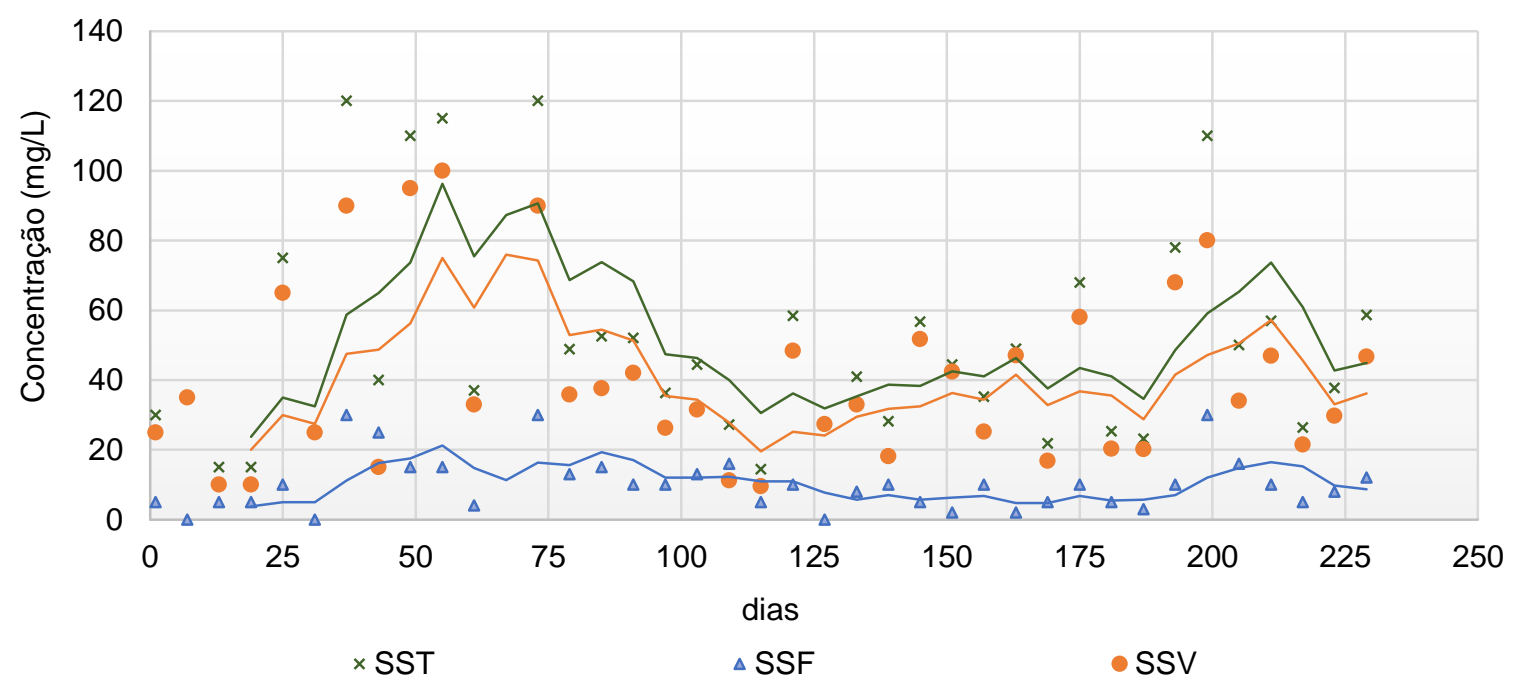

Tabela 63: Valores médios dos SST no efluente final da ETE Piloto

\begin{tabular}{c|c|c|c}
\hline \multicolumn{4}{c}{ Sólidos em suspensão (mg/L) } \\
\hline Variável & SST & SSF & SSV \\
\hline média & 50 & 10 & 40 \\
\hline máximo & 120 & 30 & 100 \\
\hline mínimo & 14 & 0 & 10 \\
\hline DP & 35 & 8 & 25 \\
\hline CV (\%) & 60 & 78 & 62 \\
\hline $\mathbf{n}$ & 38 & 38 & 38 \\
\hline
\end{tabular}

${ }^{*}$ média das determinações da amostragem compostas de 24 horas, proporcionais a vazão afluente.

Figura 94: Diagramas Box-Whiskers dos SST no efluente final da ETE Piloto

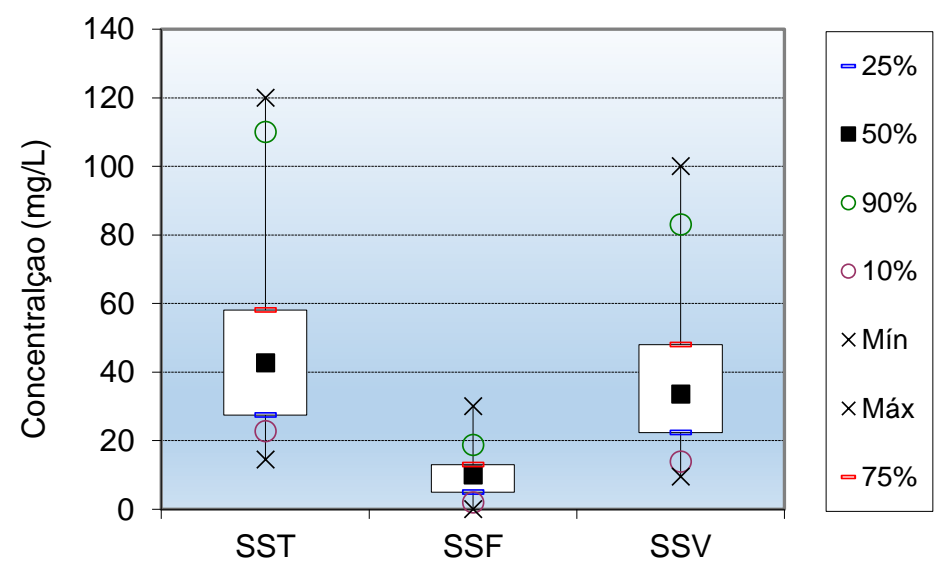


Os resultados mostram que as concentrações de sólidos em suspensão totais ficaram na faixa de 14 a $120 \mathrm{mg} / \mathrm{L}$, com valor médio de $50 \mathrm{mg} / \mathrm{L}$, esses valores foram inferiores os valores observados em escala real, que foram de 10 a $375 \mathrm{mg} / \mathrm{L}$, com média de 117 mg/L no ano de 2015. Levando-se em conta a perda de sólidos, a idade do lodo na ETE piloto foi controlada em 12 dias. Sob condições de operação similares ao de escala real, a ETE piloto foi operada com OD na faixa de 0,3 a 1,0 mgO $/ 2$ L. Esses resultados indicam que a baixa concentração de OD no tanque de aeração na ETE piloto não afetou a floculação do lodo ativado, produzindo um efluente bem clarificado. Isto, pode estar relacionado ao controle operacional que foi mais rigoroso na ETE piloto, em termos de descarte de lodo em excesso e no controle da vazão de esgoto a entrada do processo de lodos ativados. Em escala real, em condições dinâmicas com grandes variações na vazão à entrada do processo de tratamento junto com as limitações físicas, contribuíram para perca excessiva de sólidos com o esgoto à saída do processo.

\subsection{3 Índice volumétrico do lodo nos tanques de aeração}

$\mathrm{Na}$ Tabela 64 apresenta-se os resultados do índice volumétrico do lodo obtido durante o período de estudo.

Tabela 64: Índice volumétrico do lodo no tanque de aeração da ETE Piloto

\begin{tabular}{c|c}
\hline Variável & IVL $(\mathbf{m L} / \mathbf{g})$ \\
\hline Média & 186 \\
\hline Máximo & 241 \\
\hline Mínimo & 89 \\
\hline DP & 54 \\
\hline CV (\%) & 15 \\
\hline N & 20 \\
\hline
\end{tabular}

Os resultados de IVL foram similares aos obtidos em escala real e muito próximo aos encontrados na literatura para sistemas operados com baixa aeração (BUENO, 2011). Isto significa que a baixa aeração pode trazer algum prejuízo na floculação.

\subsubsection{Concentrações de OD nos tanques de aeração}

Na Figura 95, observa-se os valores diários em série temporal com médias móveis de 4 termos das concentrações de OD no tanque de aeração. Esses valores 
correspondem à média das medições de OD realizada e registrada a cada segundo diariamente durante todo o período do estudo. Com os dados da série temporal construímos a Tabela 65 e a Figura 96 onde observa-se os valores médios e os desvios obtidos durante o período de estudo.

Figura 95: Série temporal (média diária): OD nos tanques de aeração

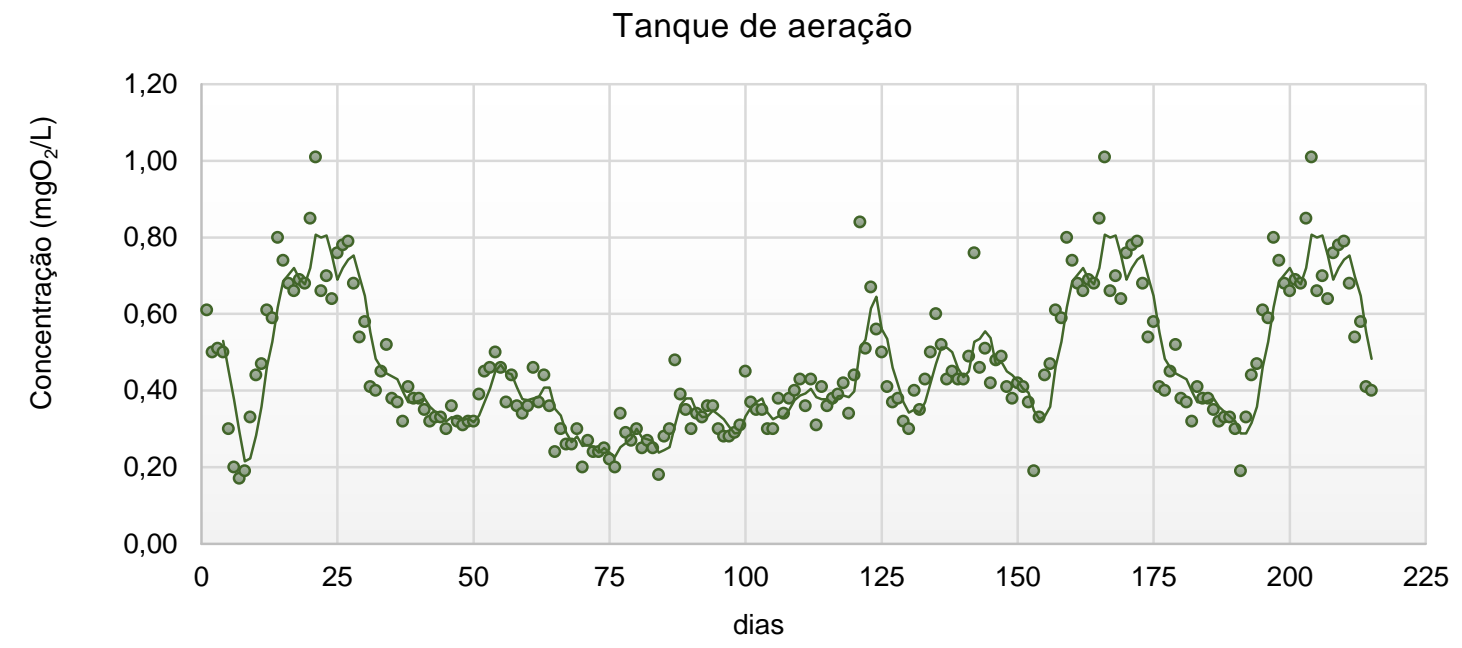

Tabela 65: Valores de OD no lodo do tanque de aeração da ETE Piloto

\begin{tabular}{c|c}
\hline Variável & OD $(\mathbf{m g} / \mathbf{L})$ \\
\hline média & 0,46 \\
\hline máximo & 1,01 \\
\hline mínimo & 0,17 \\
\hline DP & 0,18 \\
\hline CV (\%) & 38 \\
\hline $\mathbf{n}$ & 215 \\
\hline
\end{tabular}

Figura 96: Diagramas Box-Whiskers do OD do lodo no tanque de aeração da ETE Piloto

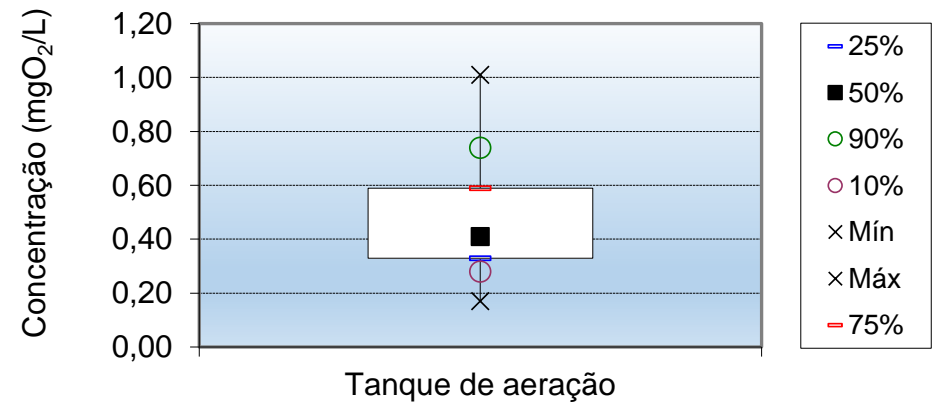




\subsubsection{Remoção de Material Orgânico}

\subsubsection{Resultados da DBO no afluente e efluente do sistema de lodo ativado}

Na Figura 97, apresenta-se os resultados com médias móveis de 4 termos da concentração de DBO e DQO (total e solúvel) do esgoto à entrada e à saída do processo de lodos ativados da ETE piloto, esses valores correspondem a médias das determinações compostas realizadas durante o estudo. Esses resultados são lançados em formas de média na Tabela 66 e 67 e na Figura 98, onde observa-se a dispersão dos resultados em forma de gráficos Box-Whiskers.

Figura 97: Série temporal das concentrações de DBO e DQO (total e solúvel) à entrada e à saída do processo de lodos ativados da ETE Piloto
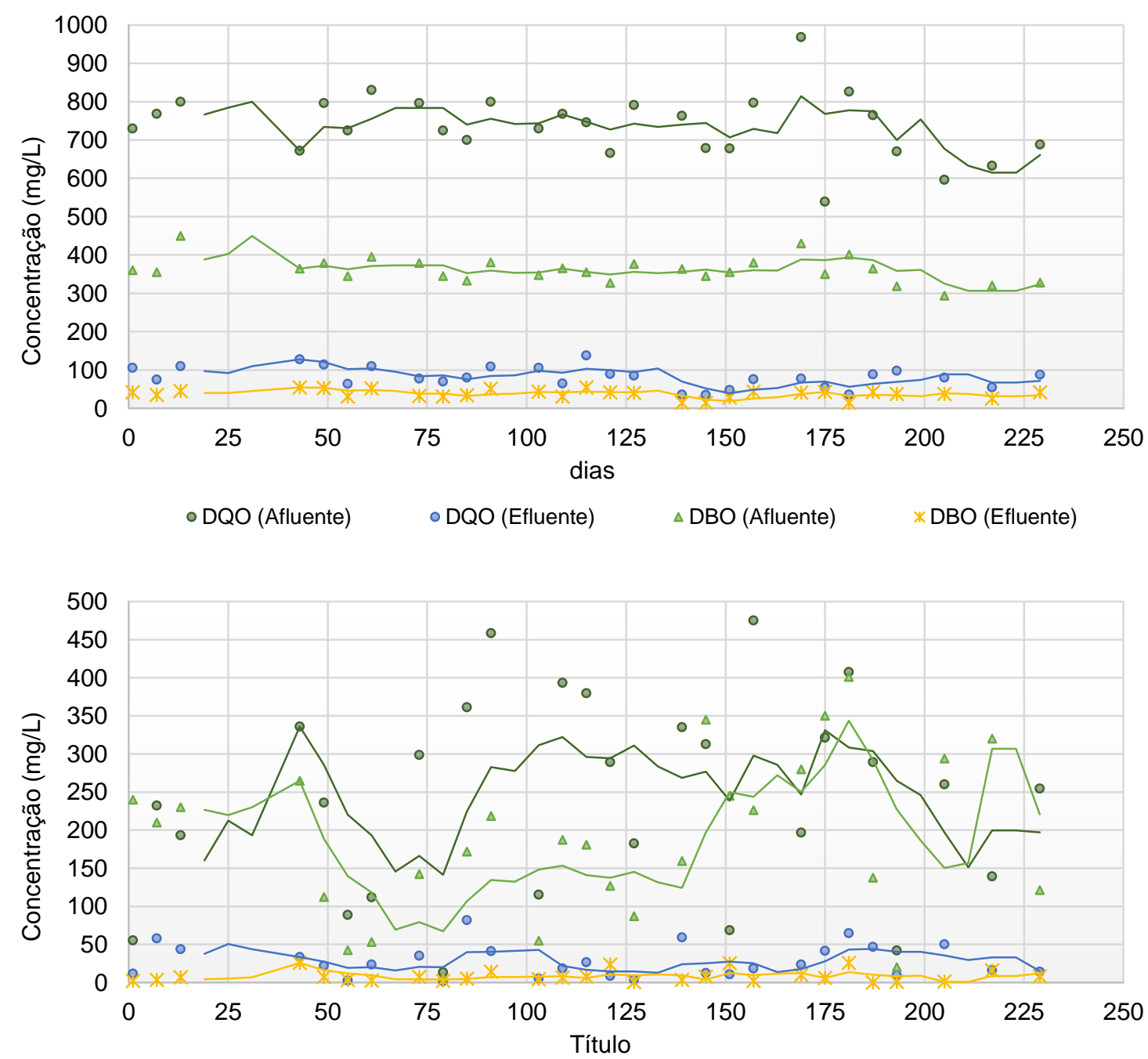

-DQOs (Afluente) $\quad$ DQOs (Efluente) $\triangle \mathrm{DBOs}$ (Afluente) $\quad *$ DBOs (Efluente) 
Tabela 66: Concentrações médias de DBO e DQO (total) no processo de lodos ativados da ETE Piloto

\begin{tabular}{c|c|c|c|c|c|c}
\hline \multirow{2}{*}{ Variável } & \multicolumn{2}{|c|}{$\begin{array}{c}\text { DQO } \\
\text { (mg/L) }\end{array}$} & \multicolumn{2}{c|}{$\begin{array}{c}\text { DBO } \\
\text { (mg/L) }\end{array}$} & \multicolumn{2}{c}{ Eficiência (\%) } \\
\cline { 2 - 7 } & Afluente & Efluente & Afluente & Efluente & DQO & DBO \\
\hline média & 737 & 82 & 361 & 38 & 89 & 90 \\
\hline máximo & 968 & 138 & 450 & 55 & 96 & 96 \\
\hline mínimo & 539 & 35 & 294 & 15 & 81 & 85 \\
\hline DP & 84 & 27 & 33 & 11 & 4 & 3 \\
\hline CV (\%) & 11 & 33 & 9 & 30 & 4 & 3 \\
\hline $\mathbf{n}$ & 28 & 28 & 28 & 28 & 28 & 28 \\
\hline
\end{tabular}

Tabela 67: Concentrações médias de DBO e DQO (solúvel) no processo de lodos ativados da ETE Piloto

\begin{tabular}{c|c|c|c|c|c|c}
\hline \multirow{2}{*}{ Variável } & \multicolumn{2}{|c|}{$\begin{array}{c}\text { DQO } \text { solúvel } \\
\text { (mg/L) }\end{array}$} & \multicolumn{2}{c|}{$\begin{array}{c}\text { DBO solúvel } \\
\text { (mg/L) }\end{array}$} & \multicolumn{2}{c}{ Eficiência (\%) } \\
\cline { 2 - 7 } & Afluente & Efluente & Afluente & Efluente & DQO & DBO \\
\hline média & 245 & 28 & 187 & 8 & 87,6 & 94,3 \\
\hline máximo & 475 & 82 & 401 & 26 & 97,9 & 99,9 \\
\hline mínimo & 13 & 2 & 6 & 0 & 75,1 & 68,5 \\
\hline DP & 130 & 21 & 105 & 8 & 7,1 & 6,4 \\
\hline CV (\%) & 53 & 76 & 56 & 97 & 8,0 & 7,0 \\
\hline $\mathbf{n}$ & 28 & 28 & 28 & 28 & 28 & 28 \\
\hline
\end{tabular}

Figura 98: Diagramas Box-Whiskers de DQO e DBO (total e solúvel) afluente e efluente do processo de lodos ativados da ETE Piloto.
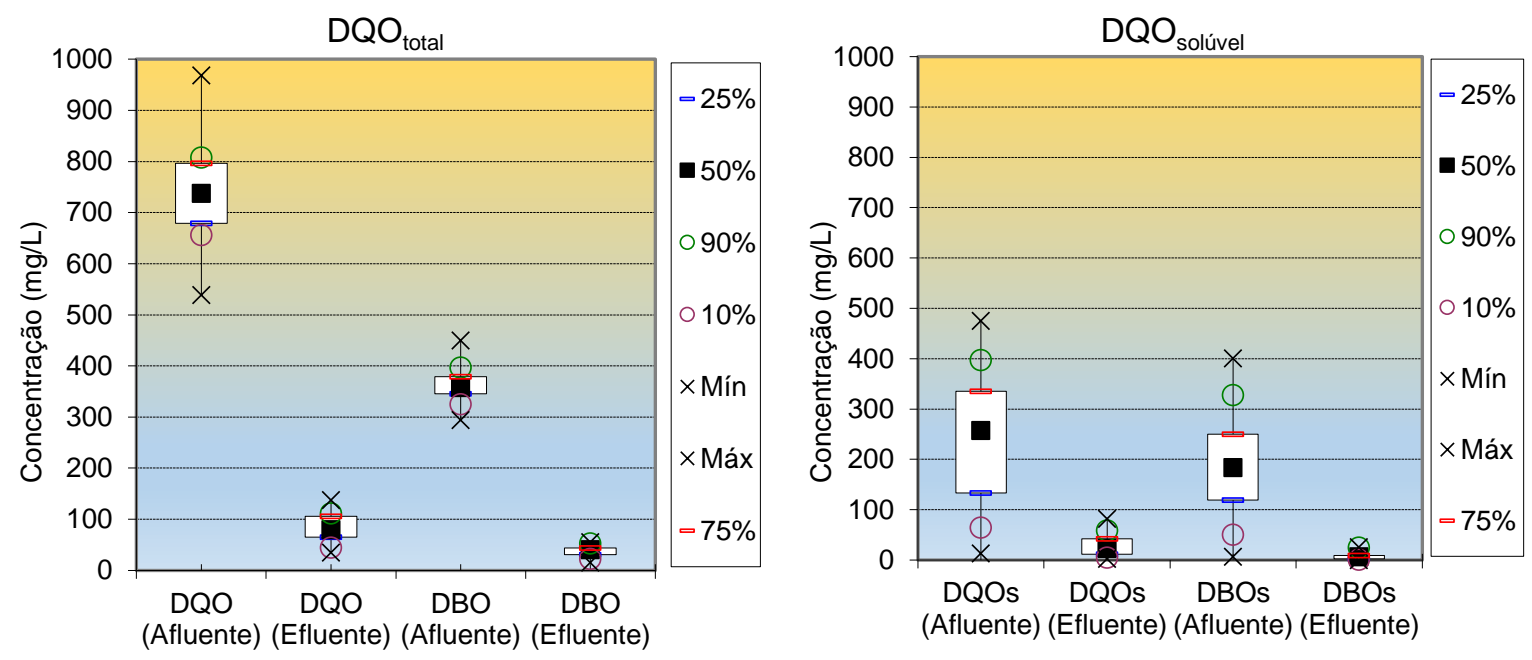
Os resultados mostram que a remoção de material orgânico no processo de lodos ativados é compatível aos alcançados em processos tradicionais operados com 1,5 $\mathrm{mg} / \mathrm{L}$ de OD. As eficiências médias de 89 e 90\% (DQO e DBO), respectivamente, foram superiores as obtidas em escala real. Nota-se que a $\mathrm{DBO}_{\text {solúvel ficou menor que }}$ $10 \mathrm{mgO}_{2} / \mathrm{L}$. Esse fato pode estar relacionado com a baixa perda de sólidos no efluente final e com o controle operacional exercido na escala piloto.

\subsubsection{Balanço de Massa do Material Orgânico}

Para o cálculo do balanço de massa do material orgânico foi necessário à realização da determinação da TCO total "in loco" $\left(\mathrm{TCO}_{\mathrm{t}}\right)$ no processo de lodos ativados da ETE Piloto. Para tanto, foi retirado uma alíquota do conteúdo do tanque de aeração e, imediatamente, executado o ensaio respirométrico, ou seja, foram feitas medidas de TCO até que se atingia a fase endógena (TCOend). Uma vez obtido os valores referentes à $\mathrm{TCO}_{t}$ e de posse dos valores da $\mathrm{TCO}$ nitrogenada $\left(\mathrm{TCO}_{n}\right)$, foi possível determinar, por diferença, a TCO correspondente a oxidação do material orgânico $\left(\mathrm{TCO}_{c}\right)$, e assim obter-se o balanço de massa. Assim, tem-se:

$\mathrm{TCO}_{\mathrm{c}}=\mathrm{TCO}_{\mathrm{t}}-\mathrm{TCO}_{\mathrm{n}}-\mathrm{TCO}_{\mathrm{end}}=75-25-14=36 \mathrm{mgO}_{2} \mathrm{~L}^{-1} \cdot \mathrm{h}^{-1}$

Em que:

TCOc: taxa de consumo de oxigênio devido a oxidação de material orgânico;

TCOn: taxa de consumo de oxigênio devido a nitrificação e

TCOt: taxa de consumo de oxigênio total ou exógena.

Nesse estudo foi adotado o modelo descrito em van Haandel e Marais, 1999.

Valores médios das determinações analíticas no período:

$\mathrm{S}_{\mathrm{ta}}=737 \mathrm{mg} \cdot \mathrm{L}^{-1} ; \mathrm{S}_{\mathrm{te}}=82 \mathrm{mg} \cdot \mathrm{L}^{-1} ; \mathrm{X}_{\mathrm{v}}=3.274 \mathrm{mgSSVL}^{-1} ; \mathrm{TCO}_{\mathrm{c}}=36 \mathrm{mgO}_{2} \mathrm{~L}^{-1} ; \mathrm{V}_{\mathrm{r}}=500 \mathrm{~L}^{-}$

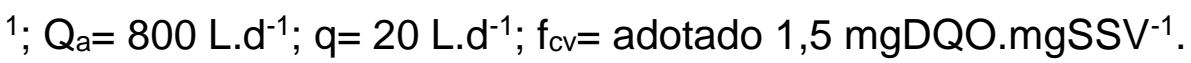


Portanto calcula-se:

Fração da DQO afluente descarregada no efluente ( $\left.m S_{t e}\right)$ :

$\mathrm{mS}_{\mathrm{te}}=\mathrm{S}_{\mathrm{te}} / \mathrm{S}_{\mathrm{ta}}=82 / 737=0,11$

Fração da DQO afluente descarregada como lodo de excesso $\left(\mathrm{mS}_{\mathrm{xv}}\right)$ :

$m S_{x v}=\left(q / Q_{a}\right)^{*} \mathrm{f}_{c v}{ }^{*} X_{v} / S_{t a}=(20 / 800)^{*} 1,5^{\star} 3.274 / 737=0,17$

Fração de DQO afluente que é oxidada no sistema $\left(\mathrm{mS}_{\circ}\right)$ :

$\mathrm{mS}_{\mathrm{o}}=\left(\mathrm{V}_{\mathrm{r}} / \mathrm{Q}_{\mathrm{a}}\right)^{*} \mathrm{TCO}_{\mathrm{c}}{ }^{*} 24 / \mathrm{S}_{\mathrm{ta}}=(500 / 800)^{*} 36^{*} 24 / 737=0,73$

A soma das três frações dá o valor do balanço de massa do material orgânico $\left(B_{0}\right)$ :

$B_{o}=\left(m S_{t e}+m S_{x v}+m S_{o}\right)=(0,11+0,17+0,73)=1,01$

Constata-se que os valores médios tiveram boa aproximação ao valor teórico $B_{0}=1,0$, estando menos que $1 \%$ distante desse resultado. Conclui-se que, em boa aproximação, o balanço de massa do material orgânico demonstrou-se consistente. Portanto os dados experimentais são confiáveis e o sistema de lodo ativado foi operado sob condições estacionárias.

\subsubsection{Remoção de Nitrogênio}

$\mathrm{Na}$ Figura 99, apresenta-se os resultados da série temporal das determinações compostas de NKT e Nitrogênio Amoniacal no esgoto à entrada e à saída do processo de lodos ativados. Esses resultados são apresentados em forma estatística na Tabela 68 e na Figura 100 em forma de gráficos de Box-Whiskers. 
Figura 99: Série temporal das concentrações de $\mathrm{NKT}_{\text {e }} \mathrm{N}-\mathrm{NH}_{3}$ à entrada e à saída do processo de lodos ativados da ETE Piloto

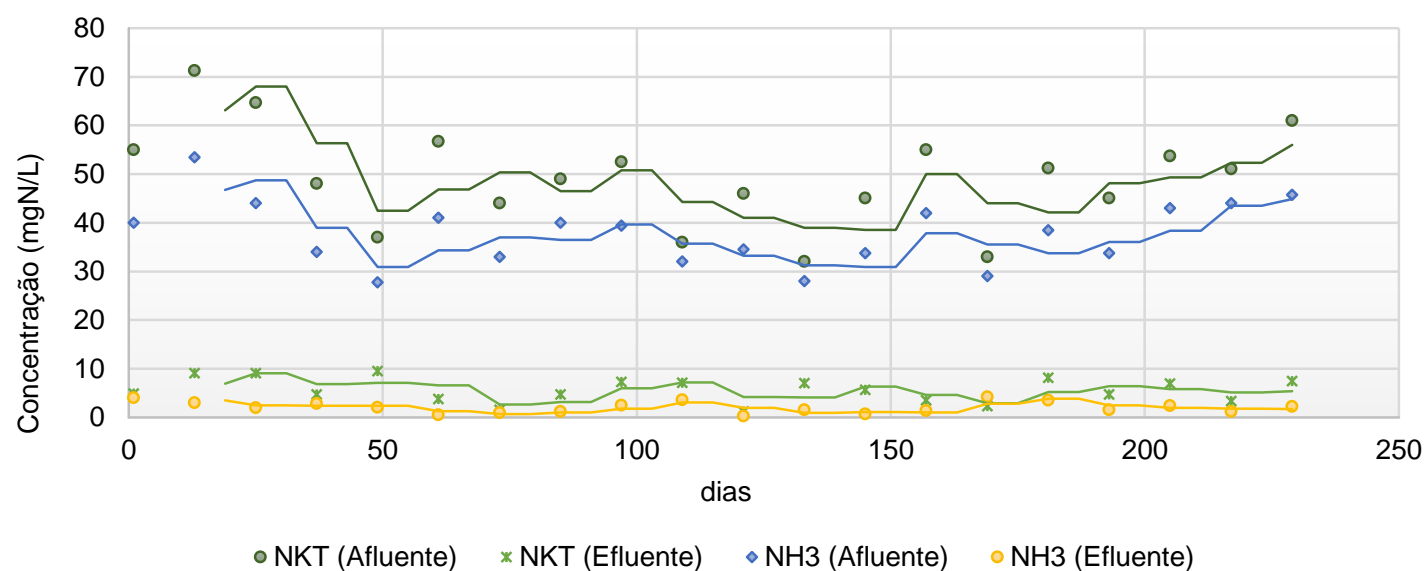

Tabela 68: NKT e N-NH 3 no processo de lodos ativados da ETE Piloto

\begin{tabular}{c|c|c|c|c}
\hline \multirow{2}{*}{ Variável } & \multicolumn{2}{|c|}{$\begin{array}{c}\text { NKT } \\
\text { (mgN/L) }\end{array}$} & \multicolumn{2}{c}{$\begin{array}{c}\text { N-NH3 } \\
\text { (mgN/L) }\end{array}$} \\
\cline { 2 - 5 } & Afluente & Efluente & Afluente & Efluente \\
\hline média & 49,4 & 5,6 & 37,8 & 2,1 \\
\hline máximo & 71,3 & 9,5 & 53,5 & 4,2 \\
\hline mínimo & 32,0 & 1,2 & 27,8 & 0,3 \\
\hline DP & 10,2 & 2,5 & 6,7 & 1,2 \\
\hline CV (\%) & 21 & 45 & 18 & 56 \\
\hline $\mathbf{n}$ & 20 & 20 & 20 & 20 \\
\hline
\end{tabular}

Figura 100: Diagramas Box-Whiskers de NKT e NH3 afluente e efluente do processo de lodos ativados da ETE Piloto.

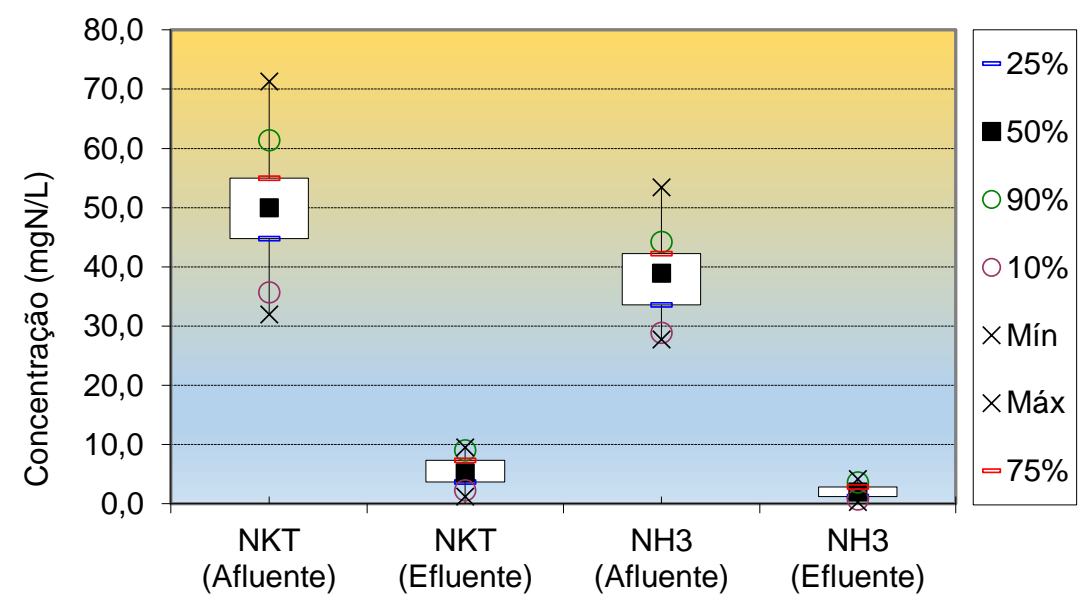




\subsubsection{Nitrato}

Na Figura 101 são apresentados os resultados da série temporal das determinações compostas do Nitrogênio Nitrato no efluente do processo de lodos ativados. Esses resultados são apresentados em forma estatística na Tabela 69 e na Figura 102 em forma de gráficos de Box-Whiskers.

Figura 101: Série temporal das concentrações de nitrato à entrada e à saída do processo de lodos ativados da ETE Piloto

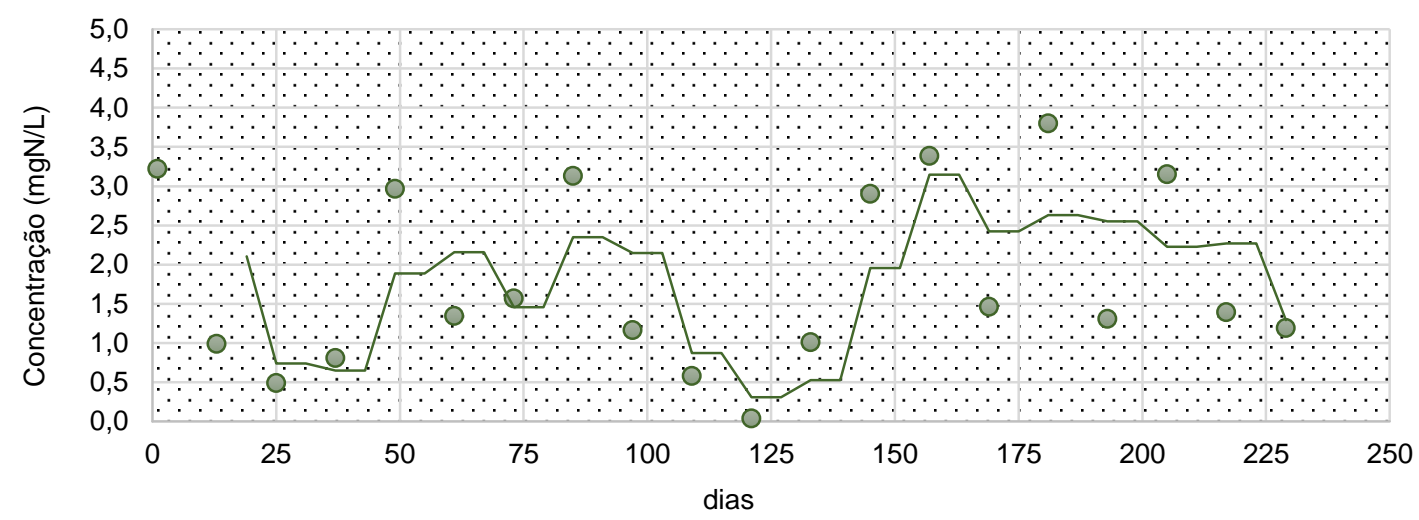

Tabela 69: Concentrações médias de nitrato no processo de lodos ativados da ETE Piloto

\begin{tabular}{c|c}
\hline Variável & Nitrato $(\mathbf{m g N} / \mathbf{L})$ \\
\hline média & 1,8 \\
\hline máximo & 3,8 \\
\hline mínimo & 0,0 \\
\hline DP & 1,1 \\
\hline CV (\%) & 64 \\
\hline $\mathbf{n}$ & 20 \\
\hline
\end{tabular}


Figura 102: Diagramas Box-Whiskers de nitrato afluente e efluente do processo de lodos ativados da ETE Piloto.

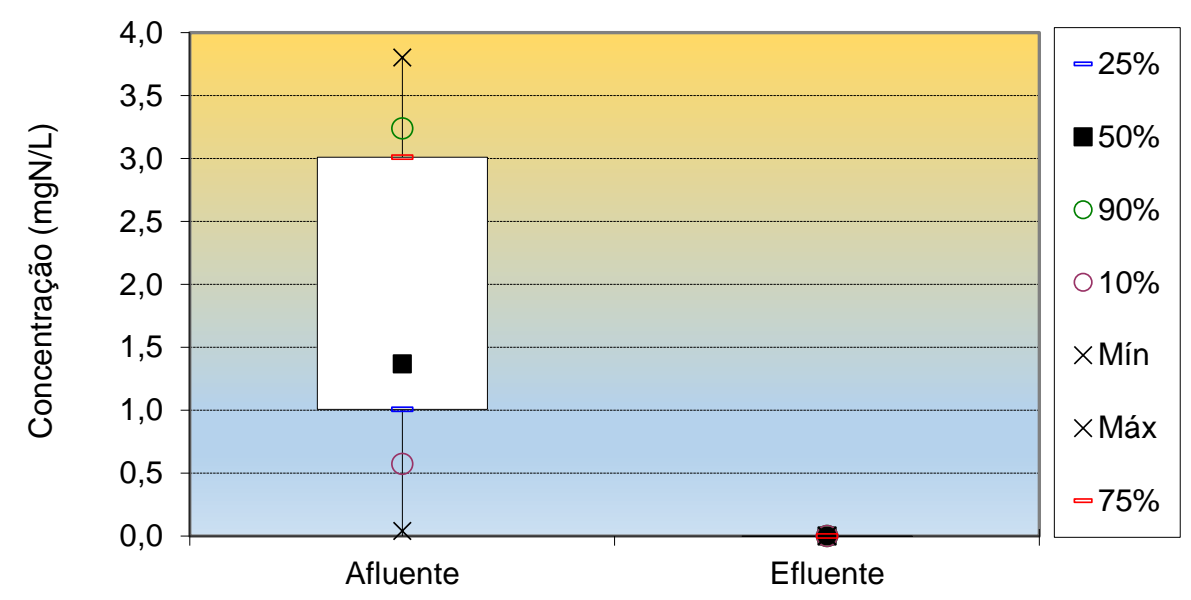

\subsubsection{Resultados do balanço de massa do material nitrogenado}

Nesse item apresenta-se o balanço de massa do material nitrogenado obtido durante a operação da ETE piloto. As determinações seguiram o modelo descrito em van Haandel e Marais, 1999 e o detalhamento de cada termo está descrito na lista de símbolos. Tem-se os seguintes valores:

$\mathrm{f}_{\mathrm{n}}=$ adotado 0,$1 ; \mathrm{Rs}_{\mathrm{S}}=12$ dias; $\mathrm{Vr}=500 \mathrm{~L}^{-1} ; \mathrm{N}_{\mathrm{oa}}=11,6 \mathrm{mgN}$-org. $\mathrm{L}^{-1} ; \mathrm{N}_{\mathrm{oe}}=3,5 \mathrm{mgN}-$ org. $\mathrm{L}^{-1} ; \mathrm{N}_{\mathrm{aa}}$ $=37,8 \mathrm{mgN}-\mathrm{NH}_{3} \cdot \mathrm{L}^{-1} ; \mathrm{Nae}_{\mathrm{ae}}=2,1 \mathrm{mgN}^{-N^{-1}}{ }^{-1} ; \mathrm{N}_{\mathrm{ne}}=1,8 \mathrm{mgNO}_{3} \cdot \mathrm{L}^{-1} ; \mathrm{X}_{\mathrm{v}}=3.274 \mathrm{mgSSVL}^{-1} ; \mathrm{Q}_{\mathrm{a}}=800$ L.d ${ }^{-1} ; r \pm 0,6$.

Portanto calcula-se:

Fluxo de material nitrogenado no lodo de excesso $\left(\mathrm{MN}_{\mathrm{I}}\right)$ :

$\mathrm{MN}_{\mathrm{l}}=\mathrm{f}_{\mathrm{n}}{ }^{*} \mathrm{~V}_{\mathrm{r}}{ }^{*} \mathrm{X}_{\mathrm{v}} / \mathrm{R}_{\mathrm{s}}=0,1^{*} 500 * 3.274 / 12=13.642$

Fluxo de material nitrogenado afluente $\left(\mathrm{MN}_{\mathrm{ta}}\right)$ :

$\mathrm{MN}_{\mathrm{ta}}=\mathrm{Q}_{\mathrm{a}}{ }^{*}\left(\mathrm{~N}_{\mathrm{oa}}+\mathrm{N}_{\mathrm{aa}}+\mathrm{N}_{\mathrm{na}}\right)=\mathrm{Q}_{\mathrm{a}}{ }^{*} \mathrm{~N}_{\mathrm{ta}}=800^{*} 49,4=39.520$

Fluxo de material nitrogenado efluente $\left(\mathrm{MN}_{\mathrm{te}}\right)$ :

$\mathrm{MN}_{\mathrm{te}}=\mathrm{Q}_{\mathrm{a}}{ }^{*}\left(\mathrm{~N}_{\mathrm{oe}}+\mathrm{N}_{\mathrm{ae}}+\mathrm{N}_{\mathrm{ne}}\right)=\mathrm{Q}_{\mathrm{a}}{ }^{*} \mathrm{~N}_{\mathrm{te}}=800^{*}(3,5+2,1+1,8)=5.280$

Fluxo de material nitrogenado desnitrificado no sistema de lodo ativado $\left(\mathrm{MN}_{\mathrm{d}}\right)$ : 
$M N_{d}=\left(Q_{a}^{*} r\right)^{*} \Delta N_{n}=\left(800^{*} 0,6\right)^{*}(11,6+37,8-2,1-1,8)=21.840$

Por fim, o balanço de massa do material nitrogenado para o sistema de lodo ativado $\left(B_{n}\right)$, pode ser determinado como se segue:

$\mathrm{B}_{\mathrm{n}}=\left(\mathrm{MN}_{\mathrm{t}}+\mathrm{MN}_{\mathrm{te}}+\mathrm{MN}_{\mathrm{d}}\right) / \mathrm{MN}_{\mathrm{ta}}=(13.642+5.280+21.840) / 39.520=1,03$

Os valores médios tiveram boa aproximação ao valor teórico $B_{n}=1,0$, estando menos que $3 \%$ distante desse resultado. Conclui-se que, em boa aproximação, o balanço de massa do material nitrogenado demonstrou-se consistente. Isto significa que os dados experimentais são confiáveis e o sistema de lodo ativado foi operado sob condições estacionárias.

\subsubsection{Variação da alcalinidade devido a amonificação, nitrificação e desnitrificação no processo de lodo ativado da ETE Piloto}

$\mathrm{Na}$ Tabela 70, apresenta-se os resultados de alcalinidade total no esgoto afluente e efluente do processo de lodos ativados.

Tabela 70: Valores médios de alcalinidade no esgoto afluente e efluente e a variação obtida experimentalmente devido à amonificação, nitrificação e desnitrificação na ETE Piloto

\begin{tabular}{c|c|c|c}
\hline \multirow{2}{*}{ Variável } & \multicolumn{3}{|c}{ Alcalinidade $\mathbf{( \mathbf { m g C a C O } _ { 3 } / \mathbf { L } )}$} \\
\cline { 2 - 4 } & Afluente & Efluente & $\Delta$ alct \\
\hline média & 235 & 116 & -125 \\
\hline máximo & 334 & 235 & -25 \\
\hline mínimo & 183 & 102 & -155 \\
\hline DP & 25,9 & 27,1 & 26,0 \\
\hline CV $(\%)$ & 12,0 & 12,0 & 12,0 \\
\hline $\mathrm{N}$ & \multicolumn{3}{|c}{} \\
\hline
\end{tabular}

Onde: $\Delta$ alct: Variação da alcalinidade devido à amonificação, nitrificação e desnitrificação.

De acordo com a estequiometria do processo, para cada mg de nitrogênio nitrificado, são consumidas $7,14 \mathrm{mg}$ de alcalinidade e para cada $\mathrm{mg}$ de $\mathrm{N}$-Nitrato desnitrificado ocorre a reposição de $3,57 \mathrm{mg}$ de alcalinidade. 
Assim, temos:

Nitrogênio amonificado:

$\mathrm{N}_{\mathrm{am}}=\mathrm{N}_{\mathrm{oa}}-\left(\mathrm{N}_{\mathrm{oe}}+\mathrm{N}_{\mathrm{l}}\right)$

$\Delta$ alcam $=3,57 \Delta \mathrm{N}_{\mathrm{am}}=3,57\left(\mathrm{~N}_{\mathrm{oa}}-\mathrm{N}_{\mathrm{oe}}-\mathrm{N}_{\mathrm{l}}\right)$

Resultados das determinações analíticas (ETE Piloto):

\begin{tabular}{c|c|c|c|c|c|c|c|c}
\hline $\mathbf{N T K}_{\mathbf{a}}$ & $\mathbf{N T K}_{\mathbf{e}}$ & $\mathbf{N H}_{3 \mathbf{a}}$ & $\mathbf{N H}_{3 \mathbf{e}}$ & $\mathbf{N}_{\text {oa }}$ & $\mathbf{N}_{\text {oe }}$ & $\mathbf{N}_{\mathbf{l}}$ & $\mathbf{N}_{\mathbf{a m}}$ & $\Delta_{\text {alcam }}$ \\
\hline 49,4 & 5,6 & 37,8 & 2,1 & 11,6 & 3,5 & 12,4 & $-4,3$ & -15 \\
\hline
\end{tabular}

$\mathrm{N}_{\mathrm{c}}=\mathrm{N}_{\mathrm{ka}}-\mathrm{N}_{\mathrm{ke}}-\mathrm{N}_{\mathrm{l}}$

$\Delta \mathrm{al} \mathrm{C}_{\mathrm{n}}=-7,14 \mathrm{~N}_{\mathrm{c}}=-7,14\left(\mathrm{~N}_{\mathrm{ka}}-\mathrm{N}_{\mathrm{ke}}-\mathrm{N}_{\mathrm{l}}\right)$

$\Delta \mathrm{N}_{\mathrm{d}}=\mathrm{N}_{\mathrm{na}}+\mathrm{N}_{\mathrm{c}}-\mathrm{N}_{\mathrm{ne}}$

$\Delta$ alc $_{d}=3,57 \Delta \mathrm{N}_{\mathrm{d}}=3,57\left(\mathrm{~N}_{\mathrm{na}}+\mathrm{N}_{\mathrm{ka}}-\mathrm{N}_{\mathrm{ke}}-\mathrm{N}_{\mathrm{l}}-\mathrm{N}_{\mathrm{ne}}\right)$

$\Delta$ alct $=\Delta$ alcam $+\Delta$ alc ${ }_{n}+\Delta a c_{d}=3,57\left(N_{o a}-N_{o e}-N_{l}\right)-7,14\left(N_{k a}-N_{k e}-N_{l}\right)+3,57\left(N_{n a}+N_{k a}-N_{k e}-N_{l}-\right.$ $\mathrm{N} n$ )

$\Delta \mathrm{alct}_{\mathrm{t}}=-3,57\left(\mathrm{Naa}_{\mathrm{a}}-\mathrm{N}_{\mathrm{na}}-\mathrm{N}_{\mathrm{ae}}+\mathrm{N}_{\mathrm{ne}}\right)=3,57\left(\Delta \mathrm{Na}_{\mathrm{a}}-\Delta \mathrm{N}_{\mathrm{n}}\right)$

Resultado do balanço:

\begin{tabular}{l|c|c|c|c|c|c|c|c|c|c}
\hline Nc & $\Delta$ alcn & Nna & Nne & $\Delta$ Nd & $\Delta$ alcd & $\Delta$ alc. teórica & Alc af & Alc ef & $\Delta$ alc. observada & $(\mathbf{R} \%)$ \\
\hline 31 & -225 & 0,0 & 1,8 & 30 & 106 & -134 & 235 & 110 & -125 & 93,4 \\
\hline
\end{tabular}

Portanto, de acordo com os resultados da série nitrogenada, deveria ter ocorrido um consumo líquido de alcalinidade de $134 \mathrm{mgCaCO}_{3} / \mathrm{L}$, enquanto que os resultados de alcalinidade experimental indicaram o consumo líquido de $125 \mathrm{mgCaCO} / \mathrm{L}$, ocorrendo, portanto $93 \%$ de recuperação. Desse modo, conclui-se que o balanço de alcalinidade no processo de lodos ativados, torna-se compatível com a ocorrência simultânea do processo de amonificação, nitrificação e desnitrificação. 


\subsection{Testes respirométricos na ETE Piloto}

\subsubsection{Atividade Metabólica das Bactérias Heterotróficas.}

Com os dados obtidos nos testes respirométricos e determinações analíticas, calcularam-se, as constantes de crescimento específico máximo das bactérias heterotróficas $(\mu \mathrm{m})$ e as taxas de utilização de material orgânico das bactérias heterotróficas ( $\left.r_{\text {máx }}\right)$. As determinações seguiram o modelo descrito em van Haandel e Marais, 1999 e o detalhamento de cada termo está descrito na lista de símbolos. Assim, tem-se os seguintes valores:

Médias da TCO obtida nos testes respirométricos com esgoto sanitário, sendo: TCO exo $=75 \mathrm{mg} \cdot \mathrm{L}^{-1} \cdot \mathrm{h}^{-1} \mathrm{e} \mathrm{TCO}_{\text {end }}=14 \mathrm{mg} \cdot \mathrm{L}^{-1} \cdot \mathrm{h}^{-1}$.

A concentração de lodo ativo $\left(X_{a}\right)$ foi determinada de duas maneiras:

(1) Pela TCO end obtida no teste respirométrico, com os seguintes valores:

$\mathrm{Y}=0,45 \mathrm{mgXa}{ }^{*} \mathrm{mDQO}^{-1} ; \mathrm{R}_{\mathrm{h}}=0,68 \mathrm{~d}^{-1} ; \mathrm{S}_{\mathrm{ta}}=737 \mathrm{mg} \cdot \mathrm{L}^{-1} ; \mathrm{b}_{\mathrm{h}}=0,24^{*} 1,04^{*(\mathrm{t}-20)} \mathrm{d}^{-1} ; \mathrm{R}_{\mathrm{s}}=12$ dias; $\mathrm{TCO}_{\text {end }}=14 \mathrm{mgO}_{2} \cdot \mathrm{L}^{-1} \cdot \mathrm{h}^{-1} ; \mathrm{f}_{\mathrm{cv}}=1,5 \mathrm{mgDQO}^{\mathrm{mgSSV}}{ }^{-1} ; \mathrm{f}=0,2$.

Portanto, calcula-se $\left(\mathrm{X}_{\mathrm{a}}\right)$, como se segue:

$X_{a}=T_{C O} d /\left[f_{c v}{ }^{*}(1-f)^{*} b_{h}\right]=\left(14^{\star} 24 /\left[1,5^{\star}(1-0,2)^{\star} 0,24^{*} 1,04^{(26,5-20)}\right]=904 \mathrm{mgXa} \cdot \mathrm{L}^{-1}\right.$

(2) Pela teoria de lodo ativado, tem-se:

$X_{a}=Y^{\star} R_{h}{ }^{\star} S_{t a} /\left(1+b_{h}{ }^{\star} R_{s}\right)^{\star} R_{h}=\left(0,45^{\star} 0,68^{\star} 737 /\left(1+0,31^{*} 12\right)^{\star} 0,68\right)^{\star} 24=780 \mathrm{mgX}_{a} \cdot L^{-1}$

Para melhor estimativa de $\left(\mathrm{X}_{\mathrm{a}}\right)$, utilizou-se a média dos resultados obtidos pelos dois métodos, onde os valores médios resultaram em 842 mgXa.L-1.

Relação Xa/Xv: 842/3274 = 0,3. 
Verifica-se o valor da fração ativa do lodo volátil inferior aos valores comumente encontrados em processos de lodos ativados, que são da ordem de 0,5 , em todos os anos. Os resultados são apresentados na Tabela 71.

Tabela 71: Valores médios das constantes cinéticas de utilização de material orgânico

\begin{tabular}{c|c|c}
\hline \multirow{2}{*}{ Variável } & \multicolumn{2}{|c}{ Constantes cinéticas das bactérias heterotróficas } \\
\cline { 2 - 3 } & $\begin{array}{c}\boldsymbol{\mu} \text { m20 } \\
\left(\mathbf{d}^{-1}\right)\end{array}$ & $\begin{array}{c}\mathbf{r}_{\text {máx }} \\
\left(\mathbf{m g D Q O} \mathbf{m g} \mathbf{X}_{\mathbf{a}} \mathbf{d}^{-1}\right)\end{array}$ \\
\hline média & 2,6 & 6,0 \\
\hline máxima & 4,2 & 8,3 \\
\hline mínima & 1,4 & 3,2 \\
\hline $\mathrm{DP}$ & 1,1 & 1,0 \\
\hline $\mathrm{CV}(\%)$ & 8,0 & 8,0 \\
\hline $\mathrm{n}$ & 6 & 6 \\
\hline
\end{tabular}

Observa-se que praticamente não houve diferença entre os resultados médios da taxa de crescimento especifico máximo $\left(\mu_{\mathrm{m} 20}\right)$ das bactérias em relação ao estudo em escala real. Esses valores são compatíveis aos encontrados na literatura $\mu \mathrm{m} 20=(1,5$ $\left.7,2 \mathrm{~d}^{-1}\right)$. Isto significa, que a baixa concentração de OD no tanque de aeração e as condições propostas para obtenção do processo de NDS não afetou negativamente o crescimento das bactérias heterotrófica do processo de lodos ativados.

\subsubsection{Constantes cinéticas das bactérias autotróficas nitritantes e nitratantes}

$\mathrm{Na}$ Tabela 72 apresenta-se os resultados médios da taxa de consumo de oxigênio exógena $\left(\mathrm{TCO}_{\mathrm{exo}}\right)$ e a taxa de consumo de oxigênio máxima (TCOn.máx) devido ao consumo de amônia e nitrito, respectivamente.

Tabela 72: Valores médios da TCO pelas BOA e BON

\begin{tabular}{|c|c|c|c|c|}
\hline \multicolumn{5}{|c|}{ Taxa de consumo de oxigênio pelas bactérias oxidadoras de amônia } \\
\hline \multirow[b]{2}{*}{ Variáveis } & \multicolumn{2}{|c|}{ BOA } & \multicolumn{2}{|c|}{ BON } \\
\hline & $\begin{array}{c}\text { TCO }_{\text {exo }} \\
\mathrm{mgO}_{2 \cdot \mathrm{L}^{-1} \cdot \mathrm{h}^{-1}}\end{array}$ & $\begin{array}{c}\text { TCOn.máx } \\
\mathrm{mgO}_{2 \cdot \mathrm{L}^{-1} \cdot \mathrm{h}^{-1}}\end{array}$ & $\begin{array}{c}\mathrm{TCO}_{\text {exo }} \\
\mathrm{mgO}_{2} \cdot \mathrm{L}^{-1} \cdot \mathrm{h}^{-1}\end{array}$ & $\begin{array}{c}\mathrm{TCO}_{\text {n.máx }} \\
\mathrm{mgO}_{2} \mathrm{~L}^{-1} \cdot \mathrm{h}^{-}\end{array}$ \\
\hline média & 36 & 22 & 22 & 8 \\
\hline máximo & 46 & 32 & 26 & 12 \\
\hline mínimo & 23 & 9 & 16 & 2 \\
\hline DP & 8 & 7 & 5 & 5 \\
\hline CV (\%) & 15 & 15 & 18 & 18 \\
\hline $\mathrm{n}$ & \multicolumn{2}{|c|}{4} & \multicolumn{2}{|c|}{4} \\
\hline
\end{tabular}

${ }^{*} \mathrm{TCO}_{\text {endógena }}=14,0 \mathrm{mgO}_{2} \cdot \mathrm{L}^{-1} \cdot \mathrm{h}^{-1}$. 
Não houve variação significativa nos resultados médios de $\mathrm{TCO}_{\text {exo }}$ e TCOn.máx para as bactérias oxidadoras de amônia e de nitrito quando comparado com os obtidos em escala real. Esses valores foram utilizados para as determinações das taxas de crescimento específico máximas das bactérias nitritantes e nitratantes $(\mu \mathrm{m})$, dos coeficientes de meia saturação $\left(K_{n}\right)$ e das taxas máximas de utilização de amônia e

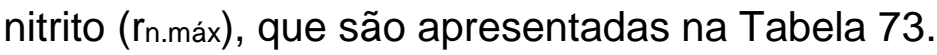

Assim, tem-se os seguintes valores:

$\mathrm{f}_{\mathrm{n}}=$ adotado 0,10 (VAN HAANDEL e MARAIS, 1999); Rs $=12$ dias; $\mathrm{V}_{\mathrm{r}}=500 \mathrm{~L}^{-1} ; \mathrm{NTK}_{\mathrm{a}}=$ 49,4 mgN-NTK.L ${ }^{-1} ;$ NTK $_{e}=5,6$ mgN-NTK.L $L^{-1} ; X_{v}=3.274$ mgSSV.L $^{-1} ; Q_{a}=800$ L.d $^{-1} ; Y_{n}=$ 0,$1 ; b_{n}=0,04(1,04)^{(26,5-20)} ; \mathrm{TCO}_{\text {exo }}=36,0 \mathrm{mgO}_{2} \cdot \mathrm{L}^{-1} \cdot \mathrm{h}^{-1} ; \mathrm{TCO}_{\text {end }}=14,0 \mathrm{mgO}_{2} \cdot \mathrm{L}^{-1} \cdot \mathrm{h}^{-1}$.

Portanto calcula-se:

Concentração das bactérias autotróficas:

$X_{n}=Y_{n} R_{s} N_{c} /\left(1+b_{n} R_{s}\right)^{*} R h=0,1^{*} 12^{*} 26,8 /\left(1+0,05^{*} 12\right)^{*} 0,68=29,6 m g X_{n} \cdot L^{-1}$

Concentração de amônia nitrificada:

$\mathrm{N}_{\mathrm{c}}=\mathrm{NTK}_{\mathrm{a}}-\mathrm{NTK}_{\mathrm{e}}-\mathrm{N}_{\mathrm{l}}=49,4-5,6-17,0=21,8 \mathrm{mgN} \cdot \mathrm{L}^{-1}$

Concentração de nitrogênio necessário para a produção de lodo:

$\mathrm{N}_{\mathrm{l}}=\mathrm{f}_{\mathrm{n}} \mathrm{X}_{\mathrm{v}} \mathrm{V}_{\mathrm{r}} / \mathrm{R}_{\mathrm{s}} \mathrm{Q}_{\mathrm{a}}=0,1^{*} 3 \cdot 274^{*} 500 / 12^{*} 800=17,0 \mathrm{mgN} \cdot \mathrm{L}^{-1}$

TCO máxima das bactérias nitritantes obtida por meio dos testes respirométricos:

$\mathrm{TCO}_{\text {n.máx }}=\mathrm{TCOexo}-\mathrm{TCO}_{\text {end }}=36-14=22 \mathrm{mgO}_{2} \cdot \mathrm{L}^{-1} \cdot \mathrm{h}^{-1}$ 
Conforme o modelo cinético utilizado como referência (VAN HAANDEL e MARAIS,1999), pode-se calcular a taxa máxima de nitritação e nitratação como se segue:

$r_{n}=\mathrm{TCO}_{n} \cdot \operatorname{máx} / 4,57=22 / 4,57=4,8 \mathrm{mg} \cdot \mathrm{L}^{-1} \cdot \mathrm{h}^{-1}$ ou $115,5 \mathrm{mg} \cdot \mathrm{L}^{-1} \cdot \mathrm{d}^{-1}$

Portanto, se calcula a taxa máxima de crescimento das BOA $\left(\mu_{\mathrm{m}}\right)$ como se segue:

$\mu_{\mathrm{m} 20}=\left(\mathrm{Y}_{\mathrm{n}}{ }^{*} \mathrm{r}_{n \text {.máx }} / \mathrm{Xn}_{\mathrm{n}}\right)^{*} 24=\left(0,1^{*} 4,8^{*} 24,0 / 29,6\right)=0,40 \mathrm{~d}^{-1}$

Tabela 73: Valores médios das constantes de crescimento específico máximo das bactérias nitrificantes $(\mu \mathrm{m} 20)$.

\begin{tabular}{|c|c|c|c|c|c|c|}
\hline \multirow{3}{*}{$\begin{array}{l}\text { Variáveis } \\
\text { Frações }\end{array}$} & \multicolumn{6}{|c|}{ Nitrificantes $\left(d^{-1}\right)$} \\
\hline & \multicolumn{3}{|c|}{$\operatorname{BOA}\left(d^{-1}\right)$} & \multicolumn{3}{|c|}{ BON $\left(d^{-1}\right)$} \\
\hline & $\mu_{\mathrm{m} 20}$ & $\mathrm{~K}_{\mathrm{n} 20}$ & rn.máx & $\mu_{\mathrm{m} 20}$ & $\mathrm{~K}_{\mathrm{n} 20}$ & rn.máx \\
\hline média & 0,40 & 0,81 & 116 & 0,51 & 0,71 & 126 \\
\hline máximo & 0,68 & 1,30 & 169 & 0,98 & 1,15 & 244 \\
\hline mínimo & 0,12 & 0,50 & 35 & 0,15 & 0,22 & 48 \\
\hline $\mathrm{DP}$ & 0,20 & 0,35 & 35 & 0,31 & 0,35 & 66 \\
\hline CV (\%) & 35 & 35 & 35 & 40 & 40 & 40 \\
\hline $\mathrm{n}$ & \multicolumn{3}{|c|}{4} & \multicolumn{3}{|c|}{4} \\
\hline
\end{tabular}

O resultado obtido em escala piloto pode ser considerado bastante parecido aos obtidos em escala real e, são compatpiveis aos da literatura $\left(0,20-1,02 d^{-1}\right)$ Metcalf \& Eddy (2003). 


\section{CONCLUSÕES E RECOMENDAÇÕES}

Em linhas gerais, pode-se concluir que o processo de lodos ativados operando com nitrificação e desnitrificação simultânea resultou em boa eficiência na remoção de nitrogênio do esgoto, aplicando-se idade do lodo na faixa de 12 dias e concentrações de oxigênio dissolvido nos reatores em torno de $0,5 \mathrm{mgO}_{2} / \mathrm{L}$. Em termos de remoção de matéria orgânica, a qualidade do efluente final na escala real pode ser considerada inferior à que normalmente ocorre em processos de lodos ativados no período de 2012 à 2013. Isto deveu-se à perda excessiva de sólidos com o efluente final, motivada por sobrecargas hidráulicas, acúmulo de lodos nos tanques de aeração por problemas na linha de tratamento de lodo, ou mesmo como decorrência das condições de baixa oxigenação impostas.

Após a otimização do sistema e melhorias na operação, houve uma melhora significativa na eficiência de remoção da matéria orgânica nos anos de 2014 e 2015.

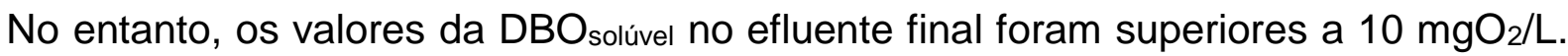
Essa condição não foi observada em escala piloto, onde se obteve um efluente final bem clarificado, com pouca perda de sólidos e $\mathrm{DBO}_{\text {solúvel }}$ menor que $10 \mathrm{mgO} / \mathrm{L}$.

Os resultados demonstram que a nitrificação do esgoto ocorreu de forma eficiente, porém, não completa. No ano de 2014 e 2015, obteve-se a concentração média de

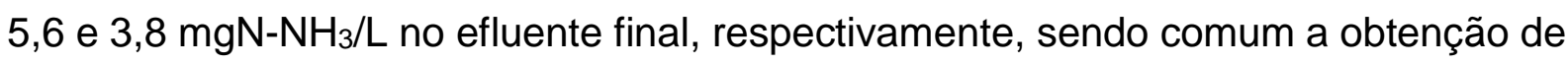
residuais da ordem de $2 \mathrm{mgN}-\mathrm{NH}_{3} / \mathrm{L}$ em processos de lodos ativados com a mesma faixa de idade do lodo, porém, com maior concentração de OD nos tanques de aeração. No entanto, ao serem observadas as séries históricas, pode-se identificar que o valor médio relativamente elevado encontrado se deve a episódios de maior prejuízo para a nitrificação. Isto pode ter ocorrido mediante substancial redução na idade do lodo ocorrida em períodos de grande perda de sólidos com o efluente final, em que a concentração de $\mathrm{N}-\mathrm{NH}_{3}$ do efluente elevou-se substancialmente.

No experimento em escala piloto as concentrações média de amônia foram de 2,1 $\mathrm{mgN}-\mathrm{NH}_{3} / \mathrm{L}$, valor compatível aos processos de lodos ativados. Isto significa que é possível obter efluentes com baixas concentrações de amônia, desde que o controle operacional seja rigoroso.

Os resultados de concentração de N-Nitrato no efluente do processo de lodos ativados em escala real e na escala piloto demonstraram a expressiva eficiência do processo 
de desnitrificação, resultando em concentrações de $\mathrm{N}-\mathrm{NO}_{3}$ no efluente final sempre abaixo de $10 \mathrm{mg} / \mathrm{L}$, que é o padrão para águas classe 2 estabelecidos na Resolução CONAMA 357/2005. Pôde ser entendido que a etapa de desnitrificação não é limitante no processo de nitrificação e desnitrificação simultânea.

Concluiu-se também ser possível, mediante controle do sistema de aeração, manter a concentração de oxigênio dissolvido variando em faixa estreita em torno de $0,5 \mathrm{mg} / \mathrm{L}$, em estação de lodos ativados em escala real, apesar das variações nas características do esgoto afluente.

Observou-se que os tanques de aeração operaram com relação SSV/SST nos lodos variando na faixa entre 0,68 a 0,71, valores que estão associados a um bom nível de digestão do lodo. Os valores da fração ativa do lodo volátil, por sua vez, resultaram inferiores aos valores comumente encontrados em processos de lodos ativados, que são da ordem de 0,5, ficando na faixa entre 0,3 a 0,4.

De acordo com os resultados da série nitrogenada, deveria ter ocorrido um consumo líquido de alcalinidade de $107 \mathrm{mgCaCO}_{3} / \mathrm{L}$, enquanto que os resultados de alcalinidade indicaram o consumo líquido de $101 \mathrm{mgCaCO} / \mathrm{L}$, ocorrendo, portanto 94 de recuperação. Esses valores são compatíveis com a ocorrência simultânea do processo de amonificação, nitrificação e desnitrificação.

Tanto no balanço de material orgânico, como no de material nitrogenado, obteve-se boa consistência, nos anos de 2013, 2014 e 2015, com desvios menores que 10\%, enquanto que, no ano de 2012, os desvios alcançaram $70 \%$ comprometendo a confiabilidade dos resultados obtidos nesse período. Os resultados do balanço de massa do material nitrogenado, mostram que a rota preferencial de remoção de nitrogênio foi via $\mathrm{N}_{2}$ com cerca de $68 \%$ de emissão desse gás, os resultados mostram que a parcela emitida via $\mathrm{N}_{2} \mathrm{O}$ pode ser desprezada.

Os resultados do teste de sedimentabilidade do lodo mostraram a necessidade de se manter uma zona com concentrações mais elevadas na porção final do tanque de aeração, de modo a melhorar a floculação do lodo biológico.

A taxa máxima de crescimento das bactérias nitritantes resultou da mesma ordem de grandeza dos valores que ocorrem em processos de lodos ativados com maior nível de oxigenação. Demonstrando que, para a faixa de idade do lodo aplicada, a manutenção de baixa concentração de OD nos tanques de aeração não traz prejuízo para a cinética da nitrificação. 
A redução da aeração trouxe uma economia média de $34 \%$ com o gasto de energia elétrica para aeração do sistema, esse valor é compatível com os apresentados na literatura.

Concluiu-se que o processo de lodo ativado com nitrificação e desnitrificação simultânea de fluxo contínuo é uma alternativa promissora de tratamento, a ser considerada tanto nos estudos de concepção para a implantação de novas estações como na adaptação de processos de lodos ativados existentes. Há ainda a necessidade de se garantir de forma inequívoca que é possível manter o lodo biológico formado nestas condições com boas características de sedimentabilidade. 


\section{REFERÊNCIAS BIBLIOGRÁFICAS}

AHN, YOUNG-HO. Sustainable Nitrogen Elimination Biotechnologies: A Review. Process Biochemistry 41.8 (2006): 1709-1721.

ALÉM SOBRINHO E GARCIA JÚNIOR, A. D. (1993). Estudos com sistemas de lodos ativados para a remoção de fósforo: efeitos sobre as características de sedimentação do lodo. XVII congresso brasileiro de engenharia sanitária e ambiental, natal, RN.

ALÉM SOBRINHO, P. (1983). Estudo dos fatores que influem no desempenho do processo de lodos Ativados - determinação de parâmetros de projeto para esgotos predominantemente domésticos. Revista DAE, 132, 49-85.

ALEM SOBRINHO, P. (1991). Contribuição ao estudo de remoção biológica de fósforo em excesso, de esgoto sanitário, por modificação do processo de lodos ativados. 1991. 2v (doctoral dissertation, tese (livre docência) - Escola Politécnica, Universidade de São Paulo, São Paulo).

ALEM SOBRINHO, P.; JORDÃO, E. P. Pós-tratamento de efluentes anaeróbiosuma análise crítica. Chernicharo, cal, coordenador. Pós-tratamento de efluentes de reatores anaeróbios. PROSAB. Belo horizonte, v. 2, p. 491-513, 2001.

ANDREOTtOlA, G., OliveIRA, E. L. D., FOLADORI, P., DALLAGO, L., PETERLINI, R., \& CADONNA, M. (2005). Método Respirométrico para o Monitoramento de Processos Biológicos. Eng. Sanitária. Ambiental, 14-23.

ANTHONISEN, A. C., LOEHR, R. C., PRAKASAM, T. B. S., \& SRINATH, E. G. (1976). Inhibition of Nitrification by Ammonia and Nitrous. Acid. Journal (Water Pollution Control Federation), 835-852.

ANTHONISEN, A. C., LOEHR, R. C., PRAKASAM, T. B. S., \& SRINATH, E. G. (1976). Inhibition of nitrification by ammonia and nitrous acid. Journal (water pollution control federation), 835-852.

ARANA, L. V. (1997). Princípios químicos de qualidade da água em aqü icultura: uma revisáo para peixes e camaróes. UFSC.

ASLAN, S., MILLER, L., \& DAHAB, M. (2009). Ammonium oxidation via nitrite accumulation under limited oxygen concentration in sequencing batch reactors. Bioresource technology, 100(2), 659-664. 
BAEK, S. H., \& PAGILLA, K. R. (2008). Simultaneous nitrification and denitrification of municipal wastewater in aerobic membrane bioreactors. Water Environment Research, 80(2), 109-117.

BAILEY J. E. \& OLLIS D. F. (1977) Biochemical Engineering Fundamentals. Mcgraw-hill, New York.

BASSIN, JOÃO PAULO. Remoção biológica de nutrientes em sistemas compactos e estudo da diversidade microbiana por técnicas de biologia molecular. Tese (doutorado em engenharia química) - Pós-graduação em Engenharia Química, UNIVERSIDADE FEDERAL DO RIO DE JANEIRO, RIO DE JANEIRO, 2012.

BRASIL, CONAMA. Resolução. № 357 De 17 De Março De 2005. Dispõe sobre a classificação dos corpos de água e diretrizes ambientais para o Seu enquadramento, bem como estabelece as condições e padrões de lançamento de efluentes. Brasília, 2005.

BRASIL, CONAMA. Resolução. №. 430 De 13 De Maio De 2011. Dispõe Sobre Condições E Padrões De Lançamento De Efluentes. Publicação. Dou, (92). Brasília, 2011.

BUENO, RODRIGO DE FREITAS. Nitrificação e desnitrificação simultânea em reator com biomassa em suspensão e fluxo contínuo de esgoto. 2011. Dissertação (mestrado em saúde ambiental) - FACULDADE DE SAÚDE PÚBLICA, UNIVERSIDADE DE SÃO PAULO, SÃO PAULO, 2011.

CAMPOS, F. Influência do Recebimento de Lixiviado de Aterro Sanitário sobre o Tratamento de Esgoto em Processo de Lodo Ativado e Reator Integrado de Lodo Ativado com Biofilme em Leito Móvel. 2014, 222p. Tese (Doutorado) - Faculdade De Saúde Pública, Universidade De São Paulo, São Paulo, 2014.

CAMPOS, J. L., GARRIDO, J. M., MOSQUERA-CORRAL, A., \& MÉNDEZ, R. (2007). Stability of a Nitrifying Activated Sludge Reactor. Biochemical Engineering Journal, 35(1), 87-92.

CATUNDA, S. Y., DEEP, G. S., VAN HAANDEL, A. C., \& FREIRE, R. (1996). Fast on-line Measurement of the Respiration Rate. In Activated Sludge Systems. Ininstrumentation and Measurement Technology Conference, 1996. Imtc-96. Conference Proceedings. Quality Measurements: The Indispensable Bridge Between Theory And Reality. leee (Vol. 2, Pp. 1320-1325). leee. 
CHANG, Y. J., \& TSENG, S. K. (1999). A Novel Double-Membrane System for Simultaneous Nitrification and Denitrification. In A Single Tank. Letters In Applied Microbiology, 28(6), 453-456.

CHEN, X., FUJIWARA, T., OHTOSHI, K., INAMORI, S., NAKAMACHI, K., \& TSUNO, H. (2010). Evaluation of a Novel Oxidation Ditch System for Biological Nitrogen and Phosphorus Removal From Domestic Sewage. Water Science \& Technology, 62(8).

CHIU, Y. C., LEE, L. L., CHANG, C. N., \& CHAO, A. C. (2007). Control of Carbon and Ammonium Ratio for Simultaneous Nitrification and Denitrification. In A Sequencing Batch Bioreactor. International Biodeterioration \& Biodegradation,59(1), 1-7.

COFALA, J., \& SYRI, S. (1998). Nitrogen Oxides Emissions, Abatement Technologies and Related Costs for Europe in the Rains Model Database. International Institute For Applied Systems Analysis (liasa), Ir-98-88, Laxenburg, Austria.

COLLIVIGNARELLI, C., \& BERTANZA, G. (1999). Simultaneous NitrificationDenitrification Processes. In Activated Sludge Plants: Performance And Applicability. Water Science And Technology, 40(4), 187-194.

CONGNA, L. (2001). Study on Nitrogen Removal by Simultaneous Nitrification and Denitrification [J]. Water \& Wastewater Engineering, 1, 007.

COSTA, A. G., FERREIRA, A. F., \& VAN HAANDEL, ADRIANUS. (2007). Monitoramento da Atividade Bacteriana de um Sistema de Lodos Ativados Bardenpho por Meio da Respirometria. Engenharia Sanitária E Ambiental, Rio De Janeiro, 12(1), 17-23.

DE BEER, DIRK; STOODLEY, PAUL; LEWANDOWSKI, ZBIGNIEW. Liquid flow and mass transport in heterogeneous biofilms. Water research, v. 30, n. 11, p. 27612765, 1996.

DE KREUK, MERLE KRISTA. Aerobic granular sludge: scaling up a new technology. Tu DELFT, DELFT UNIVERSITY OF TECHNOLOGY, 2006.

DEMOULIN, G., GORONSZY, M. C., WUTSCHER, K., \& FORSTHUBER, E. (1997). Co-current nitrification/denitrification and biological p-removal in cyclic activated 
sludge plants by redox controlled cycle operation. Water science and technology, 35(1), 215-224.

DI IACONI, C., RAMADORI, R., LOPEZ, A., \& PASSINO, R. (2007). Aerobic granular sludge systems: the new generation of wastewater treatment technologies. Industrial \& engineering chemistry research, 46(21), 6661-6665.

DOBOROW, R. M., CROSBY, D. M., \& BRUNSON, M. W. (1997). Ammonia In Fish Ponds. Southern Regional Aquaculture Center, [SI], (463).

DOWNING, A.L. Selected Subjects. In Waste Treatment. 3 Ed.: Delft, Ihe, 1978.

DOWNING, LEON S.; NERE, ROBERT. Nitrification in the activated sludge process. In: j. Proc. Inst. Sewage purification. 1964.

FEDERATION, W. E., \& AMERICAN PUBLIC HEALTH ASSOCIATION. (2005). Standard Methods for the Examination of Water and Wastewater. American Public Health Association (Apha): Washington, Dc, Usa.

FELIX, E. P., \& CARDOSO, A. A. (2004). Amônia $\left(\mathrm{NH}_{3}\right)$ atmosférica: Fontes, Transformação, Sorvedouros e Métodos de Análise. Química Nova, 27(1), 123-130.

FERREIRA, A. F. Uso da Respirometria na Avaliação da Influência do pH na Capacidade Ativa das Bactérias Nitrificantes. Dissertação De Mestrado. 80 P. Campina Grande-Pb: Ufcg, 2002.

FIGUEROA, L. A., \& SILVERSTEIN, J. (1992). The Effect of Particulate Organic Matter on Biofilm Nitrification. Water Environment Research, 64(5), 728-733.

FUNDAÇÃO NACIONAL DE SAÚDE (BRASIL). Manual De Saneamento. Funasa, 2006.

FUX, C., \& SIEGRIST, H. (2004). Nitrogen Removal from Sludge Digester Liquids by Nitrification/Denitrification or Partial Nitritation/Anammox: Environmental and Economical Considerations. Water Science \& Technology, 50(10), 19-26.

GALLOWAY, J. N., DENTENER, F. J., CAPONE, D. G., BOYER, E. W., HOWARTH, R. W., SEITZINGER, S. P., \& KARL, D. M. (2004). Nitrogen cycles: past, present, and future. Biogeochemistry, 70(2), 153-226. 
GONZALEZ-GIL, G., LENS, P. N. L., VAN AELST, A., VAN AS, H., VERSPRILLE, A. I., \& LETTINGA, G. (2001). Cluster structure of anaerobic aggregates of an expanded granular sludge bed reactor. Applied and environmental microbiology, 67(8), 3683-3692.

GORONSZY, M. C., SLATER, N., \& KONICKI, D. (1995). The cyclic activated sludge system for resort area wastewater treatment. Water science and technology, 32(9), 105-114.

GUIMARÃES, G. P., \& MELLO, W. Z. D. (2008). Nitrous oxide fluxes at the air-sea Interface In Guanabara Bay. Química Nova, 31(7), 1613-1620.

GUO, J. H., PENG, Y. Z., PENG, C. Y., WANG, S. Y., CHEN, Y., HUANG, H. J., \& SUN, Z. R. (2010). Energy saving achieved by limited filamentous bulking sludge under Low Dissolved Oxygen. Bioresource Technology, 101(4), 1120-1126.

HAANDEL, A. C. V. Nitrification and Denitrification Kinetics in the Activated Sludge Process. Cape Town: Departamento De Engenharia Civil Da University Of Cape Town, 1981. 650 P. Tese (Doutorado)

HAANDEL, A. C. V., \& CATUNDA, P. F. C. (1982). Determinação da taxa de consumo de oxigênio com sistemas de tratamento de esgoto. Engenharia Sanitária, 21(4), 481-8.

HAANDEL, A. C. V., \& VAN DER LUBBE, J. (2007). Handbook Biological Waste Water Treatment-Design And Optimisation Of Activated Sludge Systems. Webshop Wastewater Handbook.

HAANDEL, A. C. V; MARAIS, G.V.R. O Comportamento do Sistema de Lodo Ativado: Teoria e Aplicações para Projetos e Operações. Campina Grade: Epgraf 472p., 1999.

HALLING-S $\varnothing R E N S E N$, B., \& NIELSEN, S. N. (1996). A Model of Nitrogen Removal From Waste Water in a Fixed Bed Reactor Using Simultaneous Nitrification and Denitrification (SND). Ecological Modelling, 87(1), 131-141.

HÄNEL, K. (1988). Biological Treatment of Sewage by the Activated Sludge Process (Pp. 299-299). Chichester: Ellis Horwood.

HANSEN, J., SATO, M., \& RUEDY, R. (1997). Radiative Forcing and Climate Response. Journal Of Geophysical Research: Atmospheres, 102(D6), 6831-6864. 
HEIJNEN, J. J., VAN LOOSDRECHT, M. C. M., MULDER, R., WELTEVREDE, R., \& MULDER, A. (1993). Development and Scale-Up of an Aerobic Biofilm Air-Lift Suspension Reactor. Water Science And Technology, 27(5-6), 253-261.

HELLINGA, C., SCHELLEN, A. A. J. C., MULDER, J. W., VAN LOOSDRECHT, M. C. M., \& HEIJNEN, J. J. (1998). The Sharon Process: An Innovative Method for Nitrogen Removal from Ammonium-Rich Waste Water. Water Science And Technology, 37(9), 135-142.

HELMER, C., \& KUNST, S. (1998). Simultaneous Nitrification/Denitrification in an Aerobic Biofilm System. Water Science And Technology, 37(4), 183-187.

HENZE, M., HARREMOES, P., LA COUR JANSEN, J., \& ARVIN, E. (2001). Wastewater Treatment: Biological and Chemical Processes. Springer Science \& Business Media.

JETTEN, M. S., HORN, S. J., \& VAN LOOSDRECHT, M. C. (1997). Towards a more sustainable municipal wastewater treatment system. Water Science and Technology, 35(9), 171-180.

JORDAO, E. P.; PESSOa, C. A. Tratamento de Esgotos Domésticos. 6. Ed. Rio De Janeiro: Semograf Editora, Vol. 1. P.1050, 2011.

JUNGLES, M. K., FIGUEROA, M., MORALES, N., VAL DEL RÍO, Á., DA COSTA, R. H. R., CAMPOS, J. L., \& MÉNDEZ, R. (2011). Start up of a pilot scale aerobic granular reactor for organic matter and nitrogen removal. Journal of chemical technology and biotechnology, 86(5), 763-768.

KELLER, J., SUBRAMANIAM, K., GÖSSWEIN, J., \& GREENFIELD, P. F. (1997). Nutrient removal from industrial wastewater using single tank sequencing batch reactors. Water Science and Technology, 35(6), 137-144.

KUAI, L., \& VERSTRAETE, W. (1998). Ammonium Removal by the Oxygen-Limited Autotrophic Nitrification-Denitrification System. Applied And Environmental Microbiology, 64(11), 4500-4506.

KUENEN J.G. AND ROBERTSON L. A. Aerobic and Anaerobic Nitrification / Denitrification Processes. In: Water Quality International 94, Proc. lawq $17^{\text {th }}$ Biennial Conf., July 19-24, 1994, Budapest, Hungary, 91-99, 1997.

LEE, Y.-W., ONG, S.-K., SATO, C. (1997). Effects of heavy metals on nitrifying 
Bacteria. Water Science and Technology, v. 36. N. 12, pp. 69-74.

LI YING, GUO AI-JUN; ZHOU JING.IN. Study of treating high ammonia-n domestic wastewater with cass process. Procedia Environmental Sciences. vol.11 (pp.858863), 2011.

LI, JIUYI; CHEN, YONG; LI, JIN; ZHANG, DONGHUA; WANG, SHUGUANG; WANG, LIANJUN; JIANG, DONG; SUN, FEIYUN; ZHANG, QIONG. Morphological and structural characteristics of aerobic granulation. Journal of chemical technology and biotechnology, № 81, p. 823-830, 2006.

LING, J., \& CHEN, S. (2005). Impact of Organic Carbon nn Nitrification Performance of Different Biofilters. Aquacultural Engineering, 33(2), 150-162.

LIU, Y., TAY, J.-H., (2004). State of the art of biogranulation technology for wastewater treatment. Biotechnol.adv. v. 22, pp. 533-563.

LIU, YU; WANG, ZHI-WU; QIN, LEI; LIU, YONG-QIANG; TAY, JOO-HWA. Selection pressure-driven aerobic granulation in a sequencing batch reactor. Applied microbiology and biotechnology, vol. 67, p. 26-32, 2005.

LOUREIRO, LUCIANA NEVES. Panorâmica sobre emissões atmosféricas estudo de caso: Avaliação do inventário emissões atmosféricas da região metropolitana do Rio de Janeiro para fontes móveis. Tese, (Doutorado). Universidade Federal Do Rio De Janeiro - UFRJ, Rio de Janerio, 2005.

MADIGAN, T.M.; MARTINKO, J.M.; Parker, J. Brock Biology of Microorganisms, Prentice Hall, 8ª Edição, New York, 1997.

MARAIS, G., \& EKAMA, G. A. (1976). The Activated Sludge Process Part I-Steady State Behaviour. Water Sa, 2(4), 164-200.

MARTINS NETO, HENRIQUE. Sistema Cíclico de Lodo Ativado empregado para Remoção Biológica de Nutrientes de Esgoto Sanitário. 2014. Dissertação (Mestrado em Engenharia Hidráulica) - Escola Politécnica, Universidade De São Paulo, São Paulo, 2014.

MATSCHÉ N. F. (1972). The Elimination of Nitrogen In The Treatment Plant of Vienna-Blumental. Water Research, 6(4), 485-486. 
MATSCHÉ N. F. (1982). Control of bulking sludge--practical experience in austria. War. Sci. Technol. 14, 311-319.

METCALF \& EDDY, Inc. Wastewater Engineering: Treatment And Resourse Recovery. Mcgraw-Hill Education; 5 Edition, P.2048, 2013.

MEUlepas, R. J., JAGERSMA, C. G., ZHANG, Y., PETRILlO, M., CAI, H., BUISMAN, C. J., \& LENS, P. N. (2010). Trace methane oxidation and the methane dependency of sulfate reduction in anaerobic granular sludge. Fems microbiology ecology, 72(2), 261-271.

MOLINA, F., GARCIA, C., ROCA, E., \& LEMA, J. M. (2008). Characterization of anaerobic granular sludge developed in uasb reactors that treat ethanol, carbohydrates and hydrolyzed protein based wastewaters. Proteins, 1, 2-6.

MULDER, A., GRAAF, A., ROBERTSON, L. A., \& KUENEN, J. G. (1995). Anaerobic Ammonium Oxidation Discovered in a Denitrifying Fluidized Bed Reactor. Fems Microbiology Ecology, 16(3), 177-184.

MULDER, J. W., \& VAN KEMPEN, R. (1997). N-Removal by Sharon. Water Quality International, 3(1997), 30-31.

MÜNCH, E. V., LANT, P., \& KELLER, J. (1996). Simultaneous Nitrification and Denitrification in Bench-Scale Sequencing Batch Reactors. Water Research,30(2), 277-284.

NICOLELLA, C., VAN LOOSDRECHT, M. C. M., \& HEIJNEN, J. J. (2000). Wastewater Treatment with Particulate Biofilm Reactors. Journal Of Biotechnology, 80(1), 1-33.

NIELSEN, M., BOLLMANN, A., SLIEKERS, O., JETTEN, M., SCHMID, M., STROUS, M., \& REVSBECH, N. P. (2005). Kinetics, Diffusional Limitation and Microscale Distribution of Chemistry and Organisms in a Canon Reactor. Fems Microbiology Ecology, 51(2), 247-256.

NOR-ANUAR, A., UJANG, Z., VAN LOOSDRECHT, M. C. M., DE KREUK, M. K., \& OLSSON, G. (2012). Strength characteristics of aerobic granular sludge. Water science and technology, 65(2), 309. 
OLIVIER, J. G. J., BOUWMAN, A. F., VAN DER HOEK, K. W., \& BERDOWSKI, J. J. M. (1998). Global Air Emission Inventories for Anthropogenic Sources of $N^{\circ} X$, $\mathrm{NH}_{3}$ and $\mathrm{N}_{2} \mathrm{O}$ in 1990. Environmental Pollution, 102(1), 135-148.

OMETTO, J. P. H. B., \& MARTINELLI, L. A. (2008). Ciclos Biogeoquímicos. Buckeridge Ms Org, 29-53.

PASVEER, A. (1969). A Case of Filamentous Activated Sludge. Journal (Water Pollution Control Federation), 1340-1352.

PASVEER, A., \& SWEERIS, S. (1965). A New Development in Diffused Air Aeration. Journal (Water Pollution Control Federation), 1267-1274.

PENNER, J. E. (1999). Aviation and the Global Atmosphere: A Special Report of IPCC Working Groups I and lii. In Collaboration With The Scientific Assessment Panel To The Montreal Protocol On Substances That Deplete The Ozone Layer. Cambridge University Press.

PICCOLI, A. D. S. Estação de Tratamento de Esgotos: Uma análise da correlação entre a aeração e a emissão de óxido nitroso. 2010, 108p. Dissertação (Mestrado) - Fundação Oswaldo Cruz, Rio De Janeiro, 2010.

POCHANA, K., KELLER, J., \& LANT, P. (1999). Model Development for Simultaneous Nitrification and Denitrification. Water Science And Technology,39(1), 235-243.

POTH, M., \& FOCHT, D. D. (1985). 15n Kinetic Analysis of $\mathrm{N}_{2} \mathrm{O}$ Production by Nitrosomonas Europaea: An Examination Of Nitrifier Denitrification. Applied And Environmental Microbiology, 49(5), 1134-1141.

PROSAB - Programa De Pesquisas Em Saneamento Básico: Nutrientes de Esgoto Sanitário: Utilização E Remoção - Edital 5 - Livro 2, Rio De Janeiro: Editora Abes, 428 P., 2009.

RAMALHO, R.S. Introduction To Wastewater Treatment Processes. 2 Ed. New York: Academic Press, 483 P. 1983.

REGINATTO, V., TEIXEIRA, R. M., PEREIRA, F., SCHMIDELL, W., FURIGO JR, A., MENES, R., ... \& SOARES, H. M. (2005). Anaerobic ammonium oxidation in a bioreactor treating slaughterhouse wastewater. Brazilian journal of chemical engineering, 22(4), 593-600. 
RITTMANN, B. E., \& LANGELAND, W. E. (1985). Simultaneous Denitrification with Nitrification in Single-Channel Oxidation Ditches. Journal (Water Pollution Control Federation), 300-308.

ROBERTSON, L. A., \& KUENEN, J. G. (1984). Aerobic Denitrification: A Controversy Revived. Archives of Microbiology, 139(4), 351-354.

RUSTEN, B., HEM, L. J., \& ØDEGAARD, H. (1995). Nitrification of Municipal Wastewater In Moving-Bed Biofilm Reactors. Water Environment Research,67(1), 75-86.

SANTOS, E. V. M. Desnitrificação em Sistemas de Lodo Ativado. 114p. Dissertação (Mestrado) - Universidade Federal De Campina Grande (Ufcg), Campina Grande, 2009.

SATOH, H., NAKAMURA, Y., ONO, H., \& OKABE, S. (2003). Effect of Oxygen Concentration on Nitrification and Denitrification in Single Activated Sludge Flocs. Biotechnology And Bioengineering, 83(5), 604-607.

SCHMIDT, I., SLIEKERS, O., SCHMID, M., BOCK, E., FUERST, J., KUENEN, J. G., ... \& STROUS, M. (2003). New Concepts of Microbial Treatment Processes for the Nitrogen Removal In Wastewater. Fems Microbiology Reviews, 27(4), 481-492.

SCHMIDT, J. E., \& AHRING, B. K. (1996). Granular sludge formation in upflow anaerobic sludge blanket (UASB) reactors. Biotechnology and bioengineering, 49(3), 229-246.

SEN, P., \& DENTEL, S. K. (1998). Simultaneous Nitrification-Denitrification in a Fluidized Bed Reactor. Water Science And Technology, 38(1), 247-254.

SHIEH, W. K., \& LI, C. T. (1989). Performance and Kinetics of Aerated Fluidized Bed Biofilm Reactor. Journal Of Environmental Engineering, 115(1), 65-79.

SILVA FILHO, H. A. Nitrificação em Sistemas de Lodo Ativado. 134 F. Dissertação (Mestrado) - Universidade Federal De Campina Grande, Campina Grande, 2009.

TANG, W. T.; WISECARVER, K.; FAN, L. S. (1987). Dynamics of Draft Tube GasLiquid-Solid Fluidisation Bed Bioreactor for Phenol Degradation. Chem. Eng. Sci. 42, 2123-2134. 
TCHOBANOGLOUS, G. Et Al., Wastewater Engineering - Treatment and Reuse. Mcgraw Hill. Metcalf \& Eddy, Inc. International Edition. New York, 2004.

THAURÉ, D., LEMOINE, C., DANIEL, O., MOATAMRI, N., \& CHABROL, J. (2008). Optimisation of Aeration for Activated Sludge Treatment with Simultaneous Nitrification Denitrification. Water Science \& Technology, 58(3).

TURK, O., \& MAVINIC, D. S. (1989). Maintaining Nitrite Build-Up in a System Acclimated to Free Ammonia. Water Research, 23(11), 1383-1388.

UEMOTO, H., \& SAIKI, H. (1996). Nitrogen Removal by Tubular Gel Containing Nitrosomonas Europaea And Paracoccus Denitrificans. Applied And Environmental Microbiology, 62(11), 4224-4228.

VAN DONGEN, U. G. J. M., JETTEN, M. S., \& VAN LOOSDRECHT, M. C. M. (2001). The Sharon $\AA$-Anammox ${ }^{\circledR}$ Process for Treatment of Ammonium Rich Wastewater. Water Science And Technology, 44(1), 153-160.

VAN LOOSDRECHT, M. C. M., \& JETTEN, M. S. M. (1998). Microbiological Conversions In Nitrogen Removal. Water Science And Technology, 38(1), 1-7.

VAN VELDHUIZEN H.; VAN LOOSDRECHT M. C. M. Nitrogen Removal At Low Bod/N Ratio - Nitrogen Removal Over Nitrite. In The Main Process Stream Of Activated Sludge Processes, Stowa Report No. 97-34, 1997.

VERSTRAETE, W. (1975). Heterotrophic Nitrification In Soils And Aqueous Media (A Review). Biology Bulletin Of The Academy Of Sciences Of The Ussr.

VERSTRAETE, W., \& PHILIPS, S. (1998). Nitrification-Denitrification. Processes and Technologies In New Contexts. Environmental Pollution, 102(1), 717-726.

VILLAVERDE, S. (2004). Recent developments on biological nutrient removal processes for wastewater treatment. Re-views in environmental science \& bio/technology, 3(2), 171-183.

VILLAVERDE, S., FDZ-POLANCO, F., \& GARCIA, P. A. (2000). Nitrifying biofilm acclimation to free ammonia in submerged biofilters. Start-up influence.water research, 34(2), 602-610.

VILLAVERDE, S.; GARCIA, P.; LACALLE, M.L. (2001). Nitrification-Denitrification of UASB Effluents Highly Loaded with Nitrogen in an Activated Sludge Reactor 
Operated With Short Cycled Aeration. Water Science And Technology. London, V.44, N.4, P.279-286, 2001.

VON SPERLING, M. Princípios do Tratamento Biológico de Águas Residuárias. Vol. 4 Lodos Ativados. 2 Ed. Belo Horizonte: Desa Ufmg, V.1p. 428, 2002.

WANG JIANLONG; PENG YONGZHEN; WANG SHUYING; GAO YOUNGQING. Nitrogen Removal by Simultaneous Nitrification and Denitrification Via Nitrite in Sequence Hybrid Biological Reactor. Chinese Journal Of Chemical Engineering, Vol.16 (5), P.778-784, 2008.

WANG, B.; HE, S.; WANG, L.; SHUO, L. Simultaneous Nitrification and DeNitrification In MBR. Water Science And Technology, Londres, V. 52, N. 10, P. 435 - 442, 2005.

WATER ENVIRONMENT FEDERATION (WEF). Operation Of Municipal Wasterwater Treatment Plants - Manual Of Pratctice №. 11. Volume 1, Editora Mc Graw Hill, 2008.

WENTZEL, M. C., MBEWE, A., \& EKAMA, G. A. (1995). Batch Test for Measurement of Readily Biodegradable COD and Active Organism Concentrations In Municipal Waste Waters. Water Sa-Pretoria-, 21, 117-117.

WIESMANN, U. (1994). Biological Nitrogen Removal from Wastewater. Biotechnics/Wastewater, 113-154.

WIESMANN, U., (1994). Biological nitrogen removal from wastewater. In: fletcher, a.

(Ed.) "Advances in Biochemical Engineering", vol. 51, springer-verlag, berlim, p. 113154, 1994.

YOO, H., AHN, K. H., LEE, H. J., LEE, K. H., KWAK, Y. J., \& SONG, K. G. (1999). Nitrogen Removal From Synthetic Wastewater By Simultaneous Nitrification and Denitrification (SND) via Nitrite in an Intermittently-Aerated Reactor. Water Research, 33(1), 145-154.

ZENG, R. J., LEMAIRE, R., YUAN, Z., \& KELLER, J. (2003). Simultaneous Nitrification, Denitrification, and Phosphorus Removal in a Lab-Scale Sequencing Batch Reactor. Biotechnology And Bioengineering, 84(2), 170-178. 
ZHANG P, ZHOU QI, SONG L P, GU G W. Study Progress on Simultaneous Nitrification and Denitrification. Chongqing Environmental Sciences, V.23 (6): 20-24, 2001.

ZHANG, P., \& QI, Z. H. O. U. (2007). Simultaneous Nitrification and Denitrification In Activated Sludge System Under Low Oxygen Concentration. Frontiers Of Environmental Science \& Engineering In China, 1(1), 49-52.

ZHAO, H. W. (1998). Oxidation-reduction potential and organic carbon sources as two control parameters for simultaneous nitrification and denitrification in biological nutrient removal processes. Retrospective theses and dissertations, 1919-2007.

ZHAO, H. W., MAVINIC, D. S., OLDHAM, W. K., \& KOCH, F. A. (1999). Controlling Factors for Simultaneous Nitrification and Denitrification In a Two-Stage Intermittent Aeration Process Treating Domestic Sewage. Water Research, 33 (4), 961-970.

ZHOU, P., HE, J., \& QIAN, Y. (2003). Biofilm Airlift Suspension Reactor Treatment Of Domestic Wastewater. Water, Air, And Soil Pollution, 144(1-4), 81-100. 